\title{
FORMUŁY WERBALNE POLSKIEJ ETYKIETY JĘZYKOWEJ OD POŁOWY XVIII DO LAT SZEŚĆDZIESIĄTYCH XIX WIEKU
}


畨 
ANITA PAWŁOWSKA

\section{FORMUŁY WERBALNE} POLSKIEJ ETYKIETY JEZZYKOWEJ OD POLOWY XVIII DO LAT SZEŚĆDZIESIĄTYCH XIX WIEKU

ANALIZA SOCJOLINGWISTYCZNA 
Anita Pawłowska - Uniwersytet Łódzki, Wydział Filologiczny

Katedra Historii Języka Polskiego

90-404 Łódź, ul. Pomorska 171/173

RECENZENT

Stanisław Borawski

REDAKTOR WYDAWNICTWA UŁ

Elżbieta Marciszewska-Kowalczyk

\author{
SKŁAD I ŁAMANIE \\ $A G E N T$ PR
}

PROJEKT OKŁADKI

Barbara Grzejszczak

(C) Copyright by Uniwersytet Łódzki, Łódź 2014

Wydane przez Wydawnictwo Uniwersytetu Łódzkiego

Wydanie I. W.06539.14.0.D

ISBN (wersja drukowana) 978-83-7969-160-9

ISBN (ebook) 978-83-7969-705-2

Wydawnictwo Uniwersytetu Łódzkiego

90-131 Łódź, ul. Lindleya 8

www.wydawnictwo.uni.lodz.pl

e-mail: ksiegarnia@uni.lodz.pl

tel. (42) 6655863 , faks (42) 6655862 


\section{SPIS TREŚCI}

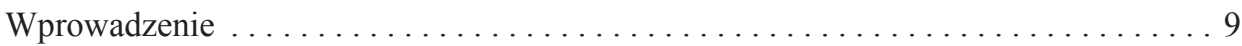

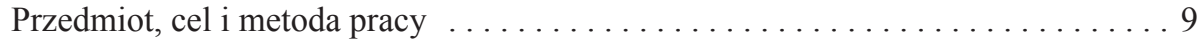

Charakterystyka źródeł . . . . . . . . . . . . . . . . . . . . 11

Stan badań . . . . . . . . . . . . . . . . . . . . . . . . . . . . . . . 14

1. Prace dotyczące współczesnej etykiety językowej . . . . . . . . . . . 14

2. Prace dotyczące dawnej etykiety językowej . . . . . . . . . . . . . 17

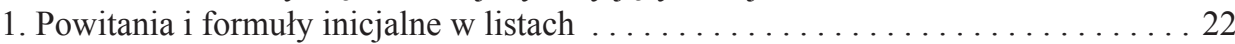

1.1. Formuły pochodzące od fraz zawierających 2. lub 3. osobę

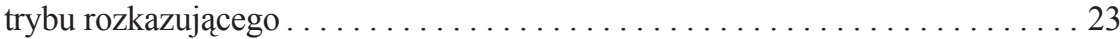

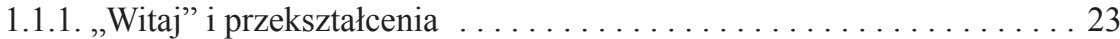

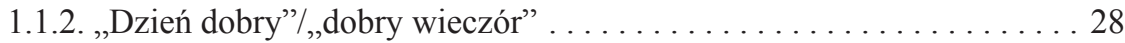

1.1.3. „Niech będzie pochwalony...” i przekształcenia . . . . . . . . . . . 33

1.2. Formuły pochodzące od fraz zawierających 1 . osobę trybu oznajmującego . . . 35

1.2.1. „Padam/ścielę się do nóg/stóp” i przekształcenia . . . . . . . . . 36

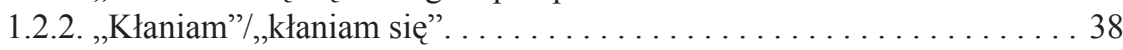

1.2.3. „Całuję rączki/stopy” i przekształcenia. . . . . . . . . . . . . . 40

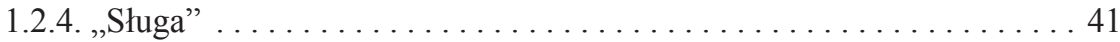

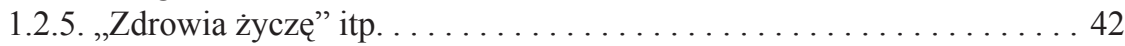

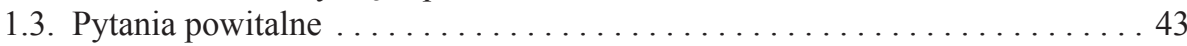

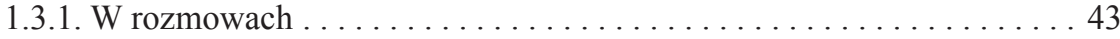

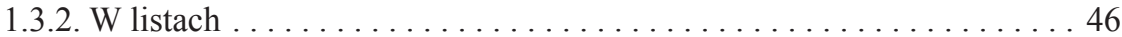

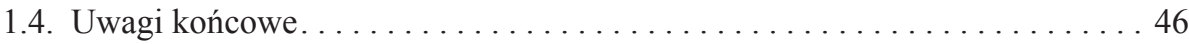

2. Pożegnania i formuły końcowe $w$ listach $\ldots \ldots \ldots \ldots \ldots \ldots \ldots \ldots \ldots$

2.1. Formuły pochodzące od fraz zawierających 2. lub 3. osobę

trybu rozkazującego . . . . . . . . . . . . . . . . . . . . . . . 49

2.1.1. „Bądź/bywaj zdrów/zdrowy” i podobne . . . . . . . . . . . . . 49

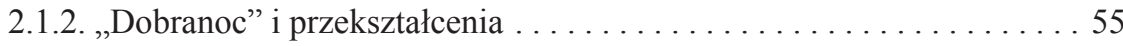

2.1.3. „Idź/jedź/bądź z Bogiem” i przekształcenia . . . . . . . . . . . 56

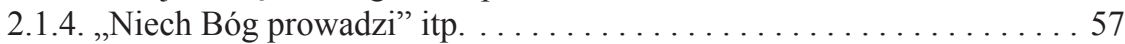

2.1.5. „Żegnaj/adieu". . . . . . . . . . . . . . . . . . . . . . . 58

2.1.6. „Niech będzie pochwalony Jezus Chrystus" . . . . . . . . . . . . . . . . 59

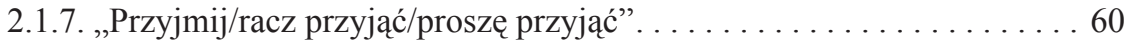

2.2. Formuły pochodzące od fraz zawierających 1. osobę trybu oznajmującego . . . 61

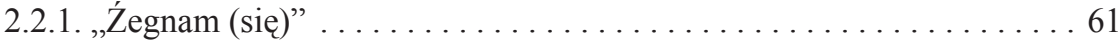

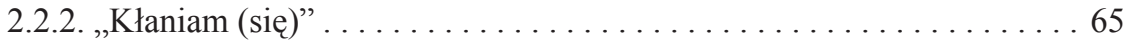

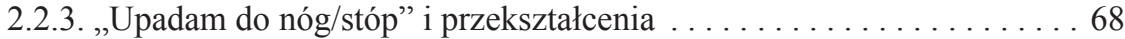

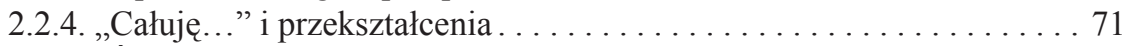

2.2.5. „Ściskam...” i przekształcenia . . . . . . . . . . . . . 76 
2.2.6. „Sługą uniżonym”, „najniższym sługą”, „podnóżkiem” itp. . . . . . . 8 80

2.2.7. „Zostaje z...”, ,jestem z...” itp. . . . . . . . . . . . . . . . . . . 83

2.2.8. „Życzę" i przekształcenia . . . . . . . . . . . . . . . . . . . 85

2.2.9. „Pozdrawiam” i przekształcenia . . . . . . . . . . . . . . . . 86

2.2.10. „Polecam się/mię”, ,oddaję mnie” . . . . . . . . . . . . . . . . 87

2.3. Formy „,do zobaczenia”, „do widzenia (się)" itp. . . . . . . . . . . . . . . 89

2.3.1. W rozmowach . . . . . . . . . . . . . . . . . . . . . . . . . 90

2.3.2. W listach ................................ 91

2.4. Uwagi końcowe. ............................... 92

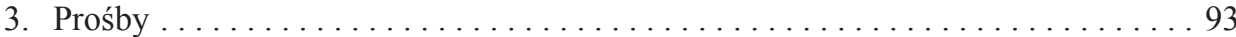

3.1. Czasowniki perlokucyjne . ......................... 93

3.1.1. Tryb rozkazujący czasownika perlokucyjnego ............ 93

3.1.2. Tryb przypuszczający czasownika perlokucyjnego ........... 95

3.1.3. Tryb przypuszczający lub czas przyszły czasownika w zdaniu pytajnym . . 96

3.1.4. „Racz” ”+ infinitivus czasownika perlokucyjnego . . . . . . . . . . . 97

3.1.5. „Raczysz”+ infinitivus czasownika perlokucyjnego ............ 98

3.1.6. „Chciej”+ infinitivus czasownika perlokucyjnego . . . . . . . . . . . . 99

3.1.7. „Zechcesz". ................................... 100

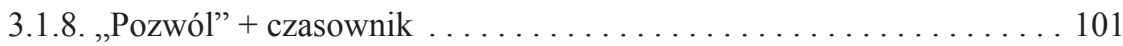

3.1.9. „Pozwolisz” + czasownik perlokucyjny . . . . . . . . . . . . . 102

3.1.10. „Bądź łaskaw” + czasownik perlokucyjny . . . . . . . . . . . . 102

3.1.11. „Zmiłuj się”, „zlituj się” + czasownik perlokucyjny. . . . . . . . 103

3.2. Czasowniki performatywne. . . . . . . . . . . . . . . . . . . . . 104

3.2.1. „Proszę" . . . . . . . . . . . . . . . . . . . . . . . . . . 104

3.2.2. „Upraszam”. ..................................... 114

3.2.3. „Suplikuje”" ................................. 116

3.2.4. „Dopraszam się" ................................... 117

3.2.5. „Życzyłbym"................................. 117

3.2.6. „Zaklinam” $i$ „błagam” ............................. 118

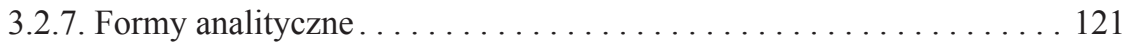

3.3. Uwagi końcowe. ............................... 123

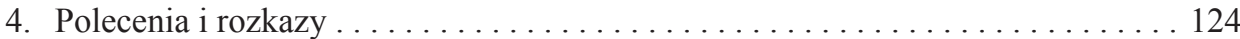

4.1. Czasowniki perlokucyjne ......................... 125

4.1.1. Formy trybu rozkazującego czasownika perlokucyjnego . . . . . 125

4.1.2. „Żebyś...” + czasownik perlokucyjny . ................ 126

4.1.3. Formy czasu przyszłego czasownika perlokucyjnego. . . . . . . . 126

4.1.4. Bezokolicznik czasownika perlokucyjnego . ............... 127

4.1.5. „Racz”, ,chciej”, ,„pozwól”, ,,bądź łaskaw” + czasownik perlokucyjny . . 127

4.1.6. „zmiłuj się" + tryb rozkazujący czasownika perlokucyjnego . . . . . . 128

4.2. Czasowniki illokucyjne .............................. 128

4.2.1. „Rozkazuje”. ............................... 128

4.2.2. „Proszę o”, ,proszę" + gen., ,proszę, aby (żeby, by)”, „proszę" + infinitivus . . . . . . . . . . . . . . . . . . . . . . . . 129

4.2.3. „Życzę", „żądam” i warianty. . . . . . . . . . . . . . . . . . 132

4.3. Uwagi końcowe.................................. 133 


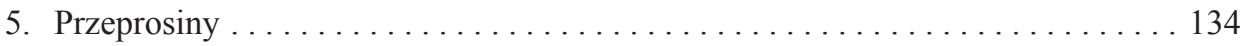

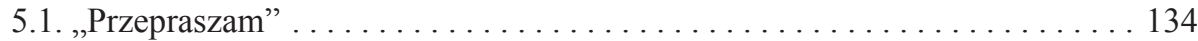

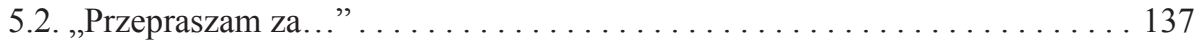

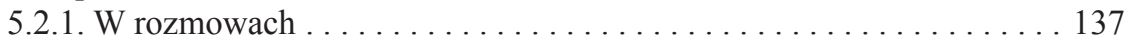

5.2.2. W listach . . . . . . . . . . . . . . . . . . . . . . 137

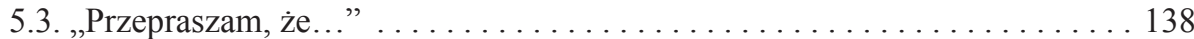

5.3.1. W rozmowach . . . . . . . . . . . . . . . . . . . . . . . . 138

5.3.2. W listach . . . . . . . . . . . . . . . . . . . . . . . . . . . . . 139

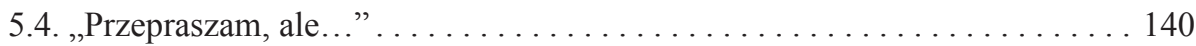

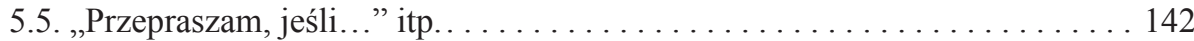

5.6. „Daruj"/,,darujesz" i przekształcenia . . . . . . . . . . . . . . . . 142

5.6.1. W rozmowach . . . . . . . . . . . . . . . . . . . . . . . . . . . . 142

5.6.2. W listach . . . . . . . . . . . . . . . . . . . . . . . . 145

5.7. „Wybacz/przebacz”, „wybaczysz/przebaczysz” i przekształcenia. . . . . . . . . 148

5.7.1. W rozmowach . . . . . . . . . . . . . . . . . . . . . . . . . . 148

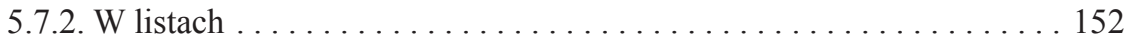

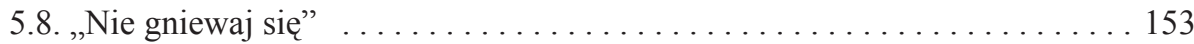

5.8.1. W rozmowach . . . . . . . . . . . . . . . . . . . . . 153

5.8.2. W listach . . . . . . . . . . . . . . . . . . . . . . . . . . . . 154

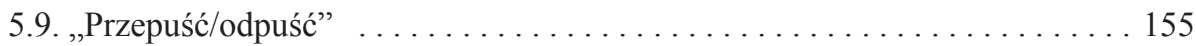

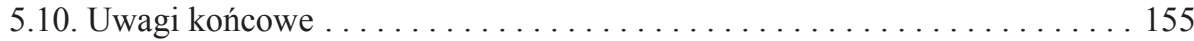

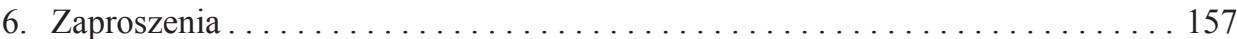

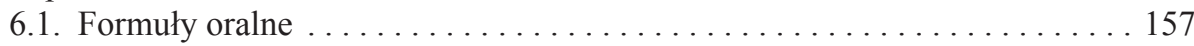

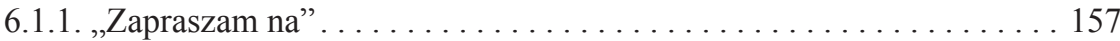

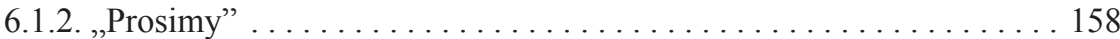

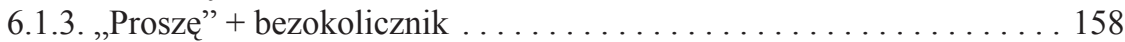

6.1.4. „Proszę na" . . . . . . . . . . . . . . . . . . . . . . . . . . . . . . . 159

6.1.5. „Proszę do" . . . . . . . . . . . . . . . . . . . . . 160

6.1.6. „Proszę” + zdanie okolicznikowe celu . . . . . . . . . . . . . . 161

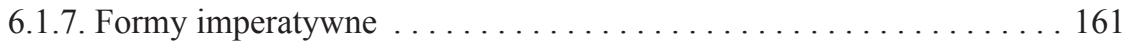

6.1.8. „Racz / pozwól” + infinitivus i przekształcenia . . . . . . . . . . 163

6.1.9. Inne formy . . . . . . . . . . . . . . . . . . . . . . . . . . . . . . . . . . 164

6.2. Formuły epistolarne. . . . . . . . . . . . . . . . . . . . . . 164

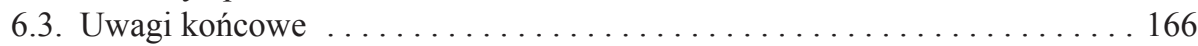

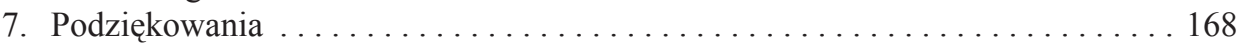

7.1. ,Dziękuję" ... . . . . . . . . . . . . . . . . . . . . . . . . 168

7.2. ,Dziękuję za" ............................. 171

7.2.1. W rozmowach . . . . . . . . . . . . . . . . . . . 171

7.2.2. W listach . . . . . . . . . . . . . . . . . . . . . . 172

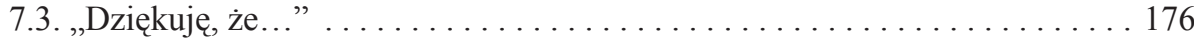

7.4. ,Składam dzięki”" i przekształcenia . . . . . . . . . . . . . . . . . 177

7.4.1. W rozmowach . . . . . . . . . . . . . . . . . . . . . . . 177

7.4.2. W listach . . . . . . . . . . . . . . . . . . . . . . . . . . 179

7.5. „Proszę przyjąć/racz przyjąć podziękowania” itp. . . . . . . . . . . . 182

7.6. ,Jestem wdzięczny/obowiązany/obligowany” i przekształcenia . . . . . . . . 182 
7.6.1. W rozmowach . . . . . . . . . . . . . . . . . . . . . . 182

7.6.2. W listach . . . . . . . . . . . . . . . . . . . . . . . . 185

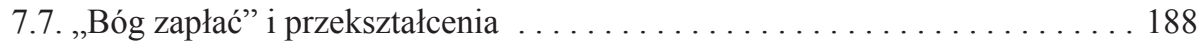

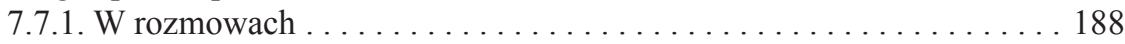

7.7.2. W listach . . . . . . . . . . . . . . . . . . . . . . . . . . . 190

7.8. „Upadam do nóg”, „Całuję rączki” itp. . . . . . . . . . . . . . . . . . . 190

7.9. „Jakże mam dziękować...?”. . . . . . . . . . . . . . . . . . . . . . . . . . . 191

7.10. Uwagi końcowe . . . . . . . . . . . . . . . . . . . . . . . 192

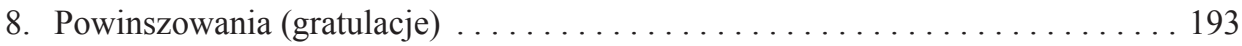

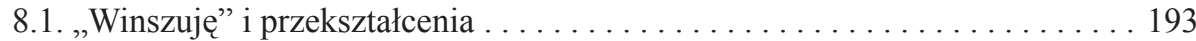

8.1.1. W rozmowach . . . . . . . . . . . . . . . . . . . . . . 193

8.1.2. W listach . . . . . . . . . . . . . . . . . . . . . . . . . 195

8.2. Uwagi końcowe. . . . . . . . . . . . . . . . . . . . 196

9. Życzenia . . . . . . . . . . . . . . . . . . . . . . . . . . . . . . 197

9.1. „Życzę" i przekształcenia. . . . . . . . . . . . . . . . . . . . . . . 197

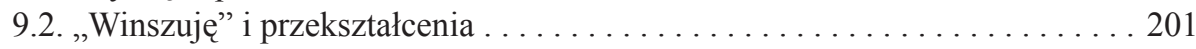

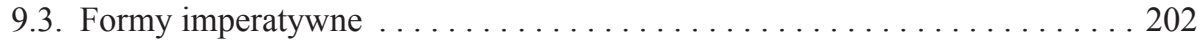

9.3.1. Formuły z opisową formą trybu rozkazującego . . . . . . . . . . . 203

9.4. Uwagi końcowe. . . . . . . . . . . . . . . . . . . . . . . . 204

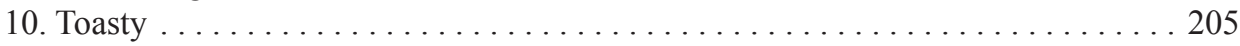

10.1. Formuły zawierające czasownik w 1. osobie i przekształcenia . . . . . . . 205

10.2. „Niech żyje...” - wiwaty w funkcji toastów . . . . . . . . . . . . . . 207

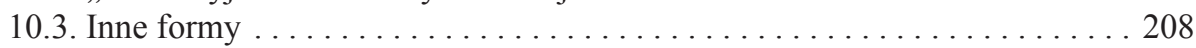

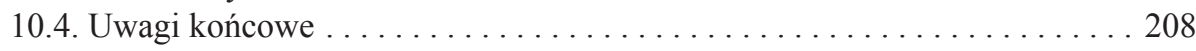

11. Przedstawianie kogoś, przedstawianie się . . . . . . . . . . . . . . . . . . 209

11.1. ,prezentuję/rekomenduję/przedstawuję" i przekształcenia . . . . . . . . . 209

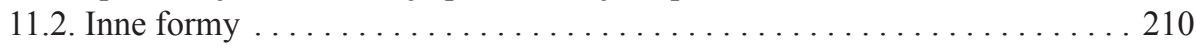

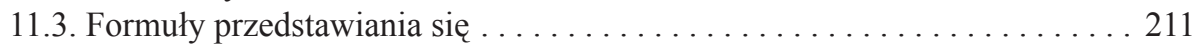

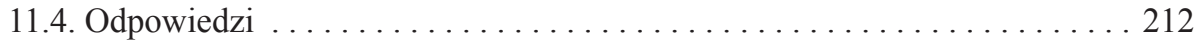

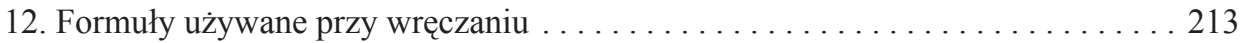

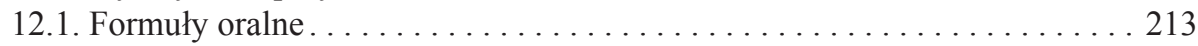

12.1.1. ,przyjmij' i przekształcenia. . . . . . . . . . . . . . . . . . . 213

12.1.2. Inne formy . . . . . . . . . . . . . . . . . . . . 214

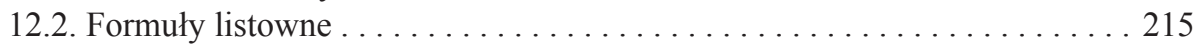

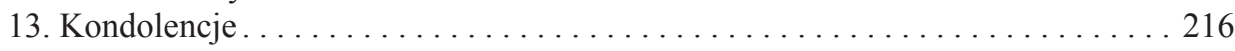

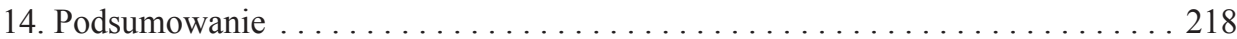

14.1. Związek z tłem historycznym i kulturowym epoki . . . . . . . . . . 218

14.2. Aspekt formalnojęzykowy . . . . . . . . . . . . . . . . . . . . . . 219

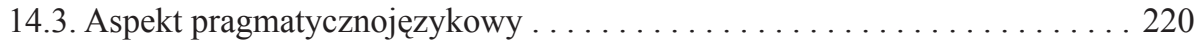

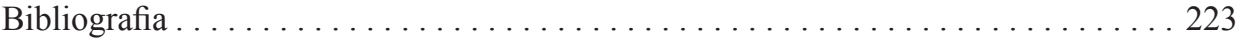

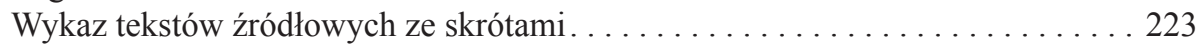

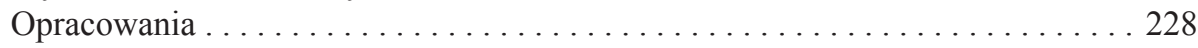




\title{
WPROWADZENIE
}

\author{
PRZEDMIOT, CEL I METODA PRACY
}

Przedmiotem pracy są formuły werbalne polskiej etykiety językowej, występujące w pierwszym wieku doby nowopolskiej. Zgodnie z definicją Małgorzaty Marcjanik etykieta językowa to „zbiór przyjętych w danej społeczności wzorów językowych zachowań grzecznościowych, zwyczajowo przyporządkowanych określonym sytuacjom pragmatycznym "'. Wyrażenia pełniące funkcję grzecznościową można podzielić na dwa rodzaje. Pierwszy z nich to autonomiczne akty etykiety językowej, pierwotnie mające formę werbalną czyli np. powitania, podziękowania, życzenia, przeprosiny. Natomiast drugi typ to elementy obudowy aktów autonomicznych, które dzielą się na werbalne np. ośmielam sie, mam honor oraz nominalne: formy adresatywne, autoadresatywne i nazywające osobę trzecią, określenia przysłówkowe i przymiotnikowe np. pilnie, szczerze, wierny, miłościwy.

W pracy omówione zostaną oba typy wyrażeń grzecznościowych, z tym jednak, że formuły werbalne, należące do autonomicznych aktów etykiety językowej, będą tu nadrzędnym kryterium klasyfikacji, prezentacji i analizy materiału. Ich ewolucja mogła powodować, że zostały skrócone o pierwotnie występujący w nich człon czasownikowy; zalicza się je tu jednak do werbalnych, ponieważ za nadrzędne uznaje się w niniejszej pracy kryterium genetyczne.

Granice czasowe wybranych do ekscerpowania tekstów wyznacza z jednej strony przełom doby średniopolskiej i nowopolskiej ${ }^{2}$, z drugiej zaś powstanie styczniowe i przełom pozytywistyczny. Badany okres jest szczególnie ciekawy, ponieważ jest to moment istotnych przemian — widoczna staje się świadomość kryzysu wartości typowych dla sarmatyzmu, co w konsekwencji powoduje zanikanie obyczajów językowych charakterystycznych dla socjolektu szlacheckiego, a w ich miejsce pojawiają się nowe formy grzecznościowe. Godne analizy są zmiany wywołane utratą państwa, wpływem idei oświeceniowych i demokratycznych, romantycznych, wpływem francuskim w okresie napoleońskim, oddziaływania rosyjskie, niemieckie i austriackie w okresie zaborów.

${ }^{1}$ M. Marcjanik, Etykieta językowa, [w:] Wspótczesny język polski, red. J. Bartmiński, Lublin 2001, s. 281.

${ }^{2}$ S. Urbańczyk, Periodyzacja dziejów polskiego języka literackiego, [w:] Prace z dziejów języka polskiego, Wrocław 1979, s. 50-62. 
Do analizy zebranego materiału wykorzystana została metoda socjolingwistyczna, według której bada się związki między sposobem używania języka a społecznymi strukturami, w których funkcjonują jego użytkownicy ${ }^{3}$ oraz teoria aktów mowy ${ }^{4}$. Z punktu widzenia socjolingwistyki akt mowy jest elementem procesu komunikowania, który podlega wpływom społecznym i kulturowym ${ }^{5}$.

Niniejsza praca mieści się też w zakresie pragmatyki językowej, gdyż opisuje relacje między znakami języka, rzeczywistością pozajęzykową a sytuacją aktu komunikacji ${ }^{6}$. Wybór strategii grzecznościowej w dużej mierze zależy od takich czynników jak władza i społeczny dystans ${ }^{7}$. W badanych formach ważne jest odróżnienie znaczenia systemowego i pragmatycznego wypowiedzi. Semantyka poprzestaje na opisaniu informacji wnoszonych przez kod językowy, natomiast pragmatyka pozwala na wskazanie znaczeń, intencji nadawcy, podtekstów i aluzji, które stają się widoczne dopiero w konkretnym użyciu języka ${ }^{8}$. Znaczenie pragmatyczne jest bardzo istotne dla badanych aktów etykiety, gdyż tylko dzięki niemu można zaobserwować znaczenia wychodzące poza konwencję. Pragmatyczne badania nad grzecznością mają na celu kontekstowe i kulturowe thumaczenie zróżnicowania zachowań językowych ${ }^{9}$.

Wstępna faza pracy polegała na wyszukiwaniu w źródłach formuł, czyli powtarzalnych elementów formalnych. Pod pojęciem formuły rozumiem grupę wyrazów, które wyrażają określoną intencję i określone wartości, relatywnie trwałą pod względem formalnym i powielaną w konkretnej sytuacji pragmatycznej ${ }^{10}$. Trzeba jednak dodać, że przedmiotem analizy są również formy jednowyrazowe, jeśli powstały wskutek redukcji grup lub gdy, przeciwnie, rozwinęły się z nich formuły. Następny etap to analiza sytuacji pragmatycznej, która pozwala ustalić zasady rządzące użyciem konkretnych form. Formuła jest rozpatrywana jako część wypowiedzi, która jest z kolei komponentem konkretnego aktu mowy. Niezbędne jest uwzględnienie tutaj elementów danej sytuacji komunikacyjnej ${ }^{11}$, które mają wpływ na kształt aktu mowy. Trzeba zatem wziąć pod uwagę czas, miejsce,

${ }^{3}$ K. Handke, Socjologia języka, Warszawa 2008, s. 9-11.

${ }^{4}$ J.R. Searle, Czynności mowy: rozważania z filozofii języka, tłum. B. Chwedeńczuk, Warszawa 1987.

D. Bula, J. Nawacka, Próba klasyfikacji aktów mowy, „Socjolingwistyka” 1983, t. 5, s. 65.

${ }^{6}$ R. Kalisz, Pragmatyka językowa, Gdańsk 1993, s. 11-20.

${ }^{7}$ Dyskurs jako struktura i proces, red. A. van Dijk, przeł. G. Grochowski, Warszawa 2001, s. 231.

${ }^{8}$ R. Grzegorczykowa, Wprowadzenie do semantyki językoznawczej, Warszawa 2001, s. 31-35.

${ }_{9}$ P. Brown, S.C. Levinson, Politeness: Some Universals in Language Usage. Studies in Interactional Sociolinguistics, Cambridge 1987.

${ }^{10}$ M. Cybulski, Obyczaje językowe dawnych Polaków. Formuly werbalne w dobie średniopolskiej, Łódź 2003, s. 7.

${ }^{11}$ Przez sytuację komunikacyjną rozumiem: „to wszystko, co dla mówiących ma znaczenie, gdy konstruują teksty, czy też to, co powinni brać pod uwagę, gdy mówią inni, wreszcie to wszystko, z czego powinni zdawać sobie sprawę, wchodząc w interakcję, przy założeniu, że stronom zależy na osiaganiu konkretnych celów". B. Boniecka, Lingwistyka tekstu. Teoria i praktyka, Lublin 1999, s. 49. 
typ kontaktu (bezpośredni, pośredni) i sytuacji (oficjalna, nieoficjalna, intymna), intencje mówiącego i cel wypowiedzi.

W przypadku formuł grzecznościowych szczególnie ważny jest aspekt socjolingwistyczny analizy, gdyż istotną ich funkcją jest wyznaczanie społecznych ról językowych. W badanym materiale kładziony jest szczególny nacisk na pozycje społeczną nadawcy i odbiorcy, na ich role komunikacyjne oraz charakter łączącej ich relacji (symetryczna lub niesymetryczna), ale również na płeć i wiek uczestników interakcji, gdyż czynniki biologiczne także mogły mieć duży wpływ na status społeczny. Uwzględnienie tych wszystkich elementów pozwoliło zobaczyć, w jaki sposób język wyraża pewne fakty społeczne i jaki obraz społeczeństwa zawierają badane formuły oraz na ile na ich stosowanie miała wpływ hierarchia społeczna.

Plan pracy określają ogólne kategorie wyznaczone przez dominującą funkcję i aspekt illokucyjny (intencję) wypowiedzi. Dalsze kryteria podziałów to struktura składniowa formuły, właściwości morfologiczne czasownika, stanowiącego jej ośrodek, czy dodatkowe elementy przy tym czasowniku np. przysłówki. W przypadku tych aktów grzecznościowych, które są bardzo bogato reprezentowane w zebranym materiale, zastosowany został dodatkowy podział na formuły konwersacyjne i formuły epistolarne - brak odpowiedniego podrozdziału oznacza, że odnotowano tylko akty ustne lub tylko pisemne.

Celem założonym w pracy jest przedstawienie repertuaru formuł werbalnych pierwszego wieku doby nowopolskiej oraz ukazanie zależności między ich formą a uwarunkowaniami pragmatycznymi ze szczególnym uwzględnieniem aspektu socjolingwistycznego.

\section{CHARAKTERYSTYKA ŹRÓDEŁ}

Podjęte w niniejszej pracy zagadnienia wymagały zgromadzenia możliwie obszernego i różnorodnego materiału. W celu omówienia aspektu pragmatycznego i socjolingwistycznego analizowanych formuł werbalnych konieczne było przebadanie korpusu tekstów, który ukazuje ich zmienność formalną i funkcyjną w możliwie szerokim kontekście społecznym i sytuacyjnym.

W badaniach etykiety językowej szczególną wartość mają źródła autentyczne: pamiętniki, dzienniki i wspomnienia. Często możemy w nich znaleźć zapisy przynajmniej fragmentów konwersacji. Choć nieraz były one rekonstruowane przez autora po długim czasie, to możemy przyjać, że przywoływane formy są prawdopodobne i dobrze obrazują język potoczny ${ }^{12} \mathrm{w}$ badanym okresie. Ich ważna zaleta to również fakt, że w przeciwieństwie do konwersacji pochodzących

${ }^{12}$ Przez język potoczny za A. Furdalem rozumiem język, którym posługujemy się na co dzień w celu porozumiewania się na tematy wspólne nam wszystkim. Zob. A. Furdal, Językoznawstwo otwarte, Wrocław 2000, s. 143-144. 
z powieści czy dramatów, zwykle pozbawione są wpływów konwencji literackich i gatunkowych. Wybierając przeznaczone do ekscerpowania teksty starano się, by ich autorzy prezentowali możliwie szeroki przekrój społeczeństwa: arystokrację, szlachtę, służbę, literatów, mieszczan i żołnierzy.

Materiał zebrany ze źródeł autentycznych jest jednak zbyt szczupły, by można na nim poprzestać i wyłącznie na jego podstawie opisywać zjawiska typowe dla języka mówionego. Badanie formuł konwersacyjnych w perspektywie diachronicznej czyni koniecznym odwoływanie się do utworów literackich - powieści i dramatów. W przypadku dzieł literackich trzeba oczywiście pamiętać, że pewien wpływ na postać i funkcje formuł może mieć konwencja gatunkowa. Wszystkie wybrane do analizy teksty charakteryzują się prawdopodobieństwem świata przedstawionego ${ }^{13}$. Zawarte $\mathrm{w}$ nich dialogi, choć niekiedy literacko przetworzone, zazwyczaj jednak mają formę językową zbliżoną do autentycznych rozmów ${ }^{14}$. Dla aspektu socjolingwistycznego pracy szczególnie ważny jest też fakt, że we wszystkich ekscerpowanych utworach można przynajmniej w przybliżeniu określić status społeczny rozmówców. Powieści i dramaty są właściwie jedynym źródłem, na podstawie którego możemy próbować rekonstruować repertuar formuł etykietalnych używanych przez najniższe warstwy społeczne, szczególnie chłopów. W przebadanych źródłach najlepiej poświadczony został oczywiście język szlachty, co nie może dziwić, zważywszy na fakt, że autorami tekstów wspomnieniowych, utworów literackich i listów były niemal wyłącznie osoby wykształcone. Wybrane do ekscerpowania teksty dramatów i powieści ukazują szeroką panoramę całego ówczesnego społeczeństwa. W badanych utworach akcja rozgrywa się nie tylko $\mathrm{w}$ arystokratycznych pałacach i szlacheckich dworkach, ale też w domach mieszczan i w wiejskich chałupach.

O ile w przypadku formuł konwersacyjnych zmuszeni jesteśmy do korzystania ze źródeł pośrednich, to badanie aktów grzecznościowych właściwych dla języka pisanego takich trudności nie napotyka. Listy to wypowiedzi dostępne nam bezpośrednio, w których możemy obserwować, oprócz innych zwrotów grzecznościowych, formuły charakterystyczne dla tego gatunku np. inscriptio, salutatio, subscriptio. Analizowane w pracy frazy epistolarne zostały wyekscerpowane ze zbiorów listów, w których jasny jest układ nadawczo-odbiorczy. Piszący pochodzili z różnych środowisk i warstw społecznych. Szczególne miejsce zajmuje tu korespondencja znanych poetów i pisarzy (A. Mickiewicza, J. Słowackiego, Z. Krasińskiego, S. Goszczyńskiego i innych), która pozwala sprawdzić na ile romantyczny indywidualizm wpłynął na postać formuł grzecznościowych stosowanych w epistolografii.

${ }^{13}$ H. Markiewicz, Glówne problemy wiedzy o literaturze, Kraków 1980, s. 124.

${ }^{14} \mathrm{O}$ przydatności tekstów literackich w badaniach dotyczących konwersacji zob. M. Kita, O możliwościach badań nad przemianami rozmowy (źródła do badań), [w:] Gatunki mowy i ich ewolucja, red. D. Ostaszewska, Katowice 2000, s. 345-353. 
Źródłem wiedzy o dawnej etykiecie językowej są też podręczniki dobrych manier i listowniki ${ }^{15}$. Trzeba jednak pamiętać, że celem takich prac nie było poświadczanie rzeczywistego stanu języka, ale tworzenie tekstów wzorcowych. Ponadto ówczesne poradniki savoir-vivre'u skupiały się raczej na omawianiu grzecznościowych zachowań niewerbalnych np. gestów, a także na udzielaniu wskazówek dotyczących moralności (szczególnie pozycje przeznaczone dla młodzieży), natomiast bardzo mało miejsca poświęcano uwagom odnoszącym się bezpośrednio do etykiety językowej.

$\mathrm{Z}$ kolei porównanie listów prezentowanych w podręcznikach epistolografii $\mathrm{z}$ autentyczną korespondencją pokazuje, że pomysły autorów tych prac rzadko stosowano w korespondencyjnej praktyce. Listy, które tam znajdujemy, są zawsze podporządkowane jednemu, często bardzo ściśle określonemu tematowi (np. doniesienie rodzicom o chorobie, doniesienie kupca, że handel swój synowi odstapit, ojciec donosi przyjacielowi o odłożeniu polowania, winszujac tanio kupionej wsi, udzielajac rady przyjacielowi, aby nie nabywat więcej pól, lecz swoje starat się polepszyć $\left.{ }^{16}\right)$. Podręczniki te zwykle również dokładnie precyzowały układ nadawczo-odbiorczy z uwzględnieniem rang społecznych nadawcy i adresata. Proponowane listy często były oparte na jakimś koncepcie, cytacie literackim, czy aluzji ${ }^{17}$. Należy także pamiętać, że wiele tego typu podręczników korzystało z obcych wzorców - przede wszystkim francuskich. Wpływ listowników na autentyczną korespondencję wydaje się niewielki.

Tak dobrane typy tekstów pozwalają na zbadanie zarówno pisemnych jak i ustnych aktów grzecznościowych charakterystycznych dla badanego okresu. Jednak zebrany materiał, mimo że dość obszerny, zawiera na pewno wiele luk - jest to nieuniknione przy badaniu zjawiska tak różnorodnego jak etykieta językowa.

Przytaczane $\mathrm{w}$ pracy cytaty $\mathrm{z}$ tekstów źródłowych podawane są zawsze $\mathrm{w}$ transkrypcji (stara ortografia jest transponowana lub powtarza się transkrypcję wydawcy).

${ }_{15}$ P. Matuszewska, Listowniki polskie. Stan i perspektywy badań, „Pamiętnik Literacki” 1982, z. 3/4, s. 41-53.

${ }^{16}$ M. Korzeniowski, Wybór wzorowych listów we wszelkich stosunkach i okolicznościach potocznego życia. Wzory do władz rzadowych, wekslów, obligów, kontraktów, cessyi, testamentów, rozmaitych zapisów, zaświadczeń, wszelkich aktów urzędowych i.t.p. z dołaczeniem krótkich obiaśnień nad temiz, Wrocław 1847, s. V.

${ }^{17}$ E. Miozga, Osiemnastowieczne listowniki. Teoria i praktyka, Katowice 2000. 


\section{STAN BADAŃ}

\section{Prace dotyczące współczesnej etykiety językowej}

Zagadnienia polskiej etykiety językowej doczekały się licznych opracowań. W większości jednak są to ujęcia synchroniczne i ograniczające zakres badań do polszczyzny mówionej.

Obecnie używanym formułom werbalnym poświęcili swoje studia: Kazimierz Ożóg, Zwroty grzecznościowe wspótczesnej polszczyzny mówionej (na materiale języka mówionego mieszkańców Krakowa) ${ }^{18}$ i Małgorzata Marcjanik, Polska grzeczność językowa ${ }^{19}$. Przedmiotem obydwu prac są autonomiczne akty etykiety językowej, ale jedynie te używane w kontaktach bezpośrednich - nie obejmują one formuł używanych w listach.

Współczesna etykieta językowa nie tylko w aspekcie opisowym, ale także normatywnym ujęta została w podręczniku M. Marcjanik pt. Grzeczność w komunikacji językowej ${ }^{20}$. Również zagadnieniom poprawnościowym poświęcona jest praca Językowy savoir-vivre. Praktyczny poradnik postugiwania sie polszczyzna $w$ sytuacjach oficjalnych i towarzyskich autorstwa Haliny i Tadeusza Zgółków ${ }^{21}$. Obydwa podręczniki uczą nie tylko podstawowych zasad etykiety konwersacyjnej, ale też reguł obowiązujących przy pisaniu listów, podań, życiorysów itp. Dodatkowo M. Marcjanik podejmuje problematykę komunikowania za pomocą nowych mediów: czatów, komunikatorów, poczty elektronicznej i SMS-ów.

Oprócz wspomnianych monografii i poradników powstało też wiele prac poświęconych konkretnym aktom etykietalnym. Trzeba wspomnieć tu o serii artykułów K. Ożoga, Powitania i pożegnania w języku mówionym mieszkańców Krakowa ${ }^{22}$, Podziękowania w polszczyźnie mówionej ${ }^{23}$ oraz Przeproszenia $w$ dzisiejszej polszczyźnie ${ }^{24}$, w których przedstawiona została formalna i socjolingwistyczna analiza tytułowych aktów etykiety językowej. Przedmiotem zainteresowań badaczy były też konkretne zwroty grzecznościowe, czego przykładem jest

${ }^{18} \mathrm{~K}$. Ożóg, Zwroty grzecznościowe współczesnej polszczyzny mówionej (na materiale języka mówionego mieszkańców Krakowa), Kraków 1990.

19 M. Marcjanik, Polska grzeczność językowa, Kielce 2000.

${ }_{20}$ M. Marcjanik, Grzeczność w komunikacji językowej, Warszawa 2007.

${ }^{21}$ H. i T. Zgółkowie, Językowy savoir-vivre. Praktyczny poradnik postugiwania się polszczyzna w sytuacjach oficjalnych i towarzyskich, Poznań 1993.

${ }^{22}$ K. Ożóg, Powitania i pożegnania w języku mówionym mieszkańców Krakowa, ,Język Polski" 1980, R. LX, s. 129-138.

${ }^{23}$ K. Ożóg, Podziękowania w polszczyźnie mówionej, „Język Polski” 1982, R. LXII, z. 4-5, s. $259-266$.

${ }^{24}$ K. Ożóg, Przeproszenia w dzisiejszej polszczyźnie, „Język Polski” 1985, R. LXV, s. 265-276. 
artykuł Haliny Zgółkowej pt. „Dobranoc” jako formuła grzecznościowa i nazwa własna ${ }^{25}$.

O strategiach używania najczęściej spotykanych w dzisiejszej polszczyźnie formuł grzecznościowych pisze Ewa Masłowska w pracy Proszę, dziękuję, przepraszam $^{26}$. Według autorki omawiane $\mathrm{w}$ artykule czasowniki illokucyjne to słowa-klucze, które pozwalają organizować relację „chcieć” na linii nadawca - odbiorca. Problematyka związana z aktami etykiety o wysokiej frekwencji została poruszona również w innych pracach. Przeprosinom poświęcony jest artykuł Alicji Gałczyńskiej Niedefinicyjne funkcje performatywu , przepraszam "27. Autorka zwraca uwagę na fakt, że za pomocą tego zwrotu grzecznościowego nie tylko przepraszamy, ale także bardzo często wyrażamy prośby, deklarujemy pomoc czy inicjujemy kontakt. O wielofunkcyjności innego performatywu pisze Andrzej Kominek w pracy Funkcje grzecznościowe „proszę” we wspótczesnej polszczyźnie ${ }^{28}$. Celem autora jest pokazanie, że roli tego czasownika nie można sprowadzać do wyrażania próśb, gdyż jest on także składnikiem oficjalnych formuł grzecznościowych, za pomocą których zwracamy się do kogoś z kim nie jesteśmy „na ty” (np. proszę pana) oraz stanowi częsty element obudowy innych aktów np. poleceń i rozkazów. Stosowane dziś formuły żądań zostały zaprezentowane w artykule Janiny Labochy pt. Sposoby wyrażania żadania we współczesnej polszczyźnie mówionej29. Próbą odpowiedzi na pytanie, za co współcześnie Polacy dziękuja jest praca M. Marcjanik pt. Struktura komunikacyjna podziękowania ${ }^{30}$. Zostały w niej szczegółowo opisane bodźce, na które reakcją jest ten akt grzeczności językowej. Autorka dokonała też klasyfikacji podziękowań ze względu na wywołujące je czynniki.

Zainteresowanie badaczy wzbudziły również formuły toastów. Poświęcone im artykuły to $O$ pewnym typie illokucji — toasty ${ }^{31}$ Elżbiety Gawędy, Krystyny Urban i Krystyny Zabierowskiej oraz Wspótczesne polskie toasty — przejawem

${ }^{25}$ H. Zgółkowa, „Dobranoc” jako formuła grzecznościowa i nazwa własna, „Studia Polonistyczne" 1979, t. VI, s. 213-216.

${ }^{26}$ E. Masłowska, Prosze, dziękuje, przepraszam, [w:] Język a kultura, t. 6, Polska etykieta językowa, red. J. Anusiewicz, M. Marcjanik, Wrocław 1992, s. 81-88.

${ }^{27}$ A. Gałczyńska, Niedefinicyjne funkcje performatywu przepraszam, „Poradnik Językowy” 2002, z. 4, s. 16-24.

${ }^{28}$ A. Kominek, Funkcje grzecznościowe „proszę” we współczesnej polszczyźnie, [w:] Język a kultura, s. 89-95.

29 J. Labocha, Sposoby wyrażania żądania we współczesnej polszczyźnie mówionej, cz. 1, „Polonica” 1985, nr 11, s. 119-146.

J. Labocha, Sposoby wyrażania żqdania we współczesnej polszczyźnie mówionej, cz. 2, „Polonica” 1986, nr 12, s. 203-217.

${ }^{30}$ M. Marcjanik, Struktura komunikacyjna podziękowania, „Socjolingwistyka” 1994, t. 14 , s. $67-76$.

${ }^{31}$ E. Gawęda, K. Urban, K. Zabierowska, O pewnym typie illokucji-toasty, „Prace Naukowe Uniwersytetu Śląskiego" 1982, Socjolingwistyka 4, s. 115-120. 
pauperyzacji życia towarzyskiego ${ }^{32} \mathrm{M}$. Marcjanik, w którym autorka stwierdza, że dzisiejsze toasty coraz rzadziej mają postać krótkich przemówień na czyją́ cześć lub za pomyślność jakiejś sprawy, a ich rola sprowadza się do zachęty do picia. Dokonuje porównania toastów dzisiejszych z dawniejszymi, opierając się na materiale zaczerpniętym $\mathrm{z}$ utworów dramatycznych oraz z podręczników dobrych manier, które zawierały wzory takich aktów. Przyczyn obecnego skracania i formalnego zubożenia toastów upatruje w czynnikach pozajęzykowych: w następującej po II wojnie światowej demokratyzacji obyczajów towarzyskich związanej z przeobrażeniami politycznymi i społecznymi.

Analizą formuł, za pomocą których składamy życzenia, zajęła się Grażyna Habrajska w artykule Struktura życzeń światecznych ${ }^{33}$, natomiast aktom pozdrawiania poświęcona jest praca Zenona Kaczyńskiego pt. Miejsce pozdrowień wśród wypowiedzi językowych ${ }^{34}$.

W obszarze zainteresowań językoznawców zdecydowanie częściej znajdowały się jednak formy adresatywne niż autonomiczne akty etykiety językowej. Początek zainteresowań sposobami zwracania się do rozmówcy, to broszura Juliana Grosse'a pt. Pan, ty, czy $w y^{35} \mathrm{z} 1906$ roku. Autor apelował w niej, aby Polacy powrócili do dawnego, szlacheckiego sposobu zwracania się do siebie przez wy. Formę pan uznał za anachronizm pochodzący z czasów feudalnych, na który nie powinno być już miejsca. Podobne postulaty możemy znaleźć też w pracy Aleksandra Brücknera Ty - Wy-Pan. Kartka z dziejów próżności ludzkiej ${ }^{36}$. Z kolei Jan Łoś w artykule Od ty do pan $^{37}$ pisze nie tylko o konwersacyjnych formach adresatywnych, ale też o tych stosowanych w ówczesnych listach. Omawia mechanizmy skracania rozbudowanych adresatywów i twierdzi, że forma pan jest przeobrażeniem pierwotnego ty.

Zainteresowanie sposobami zwracania się do rozmówcy obserwujemy także po II wojnie światowej. Już w 1946 roku ukazał się artykuł Zenona Klemensiewicza Pan i obywatel $l^{38}$, w którym autor ustosunkowywał się do tej nowej formy wprowadzonej do stylu urzędowego. Zwrotami adresatywnymi powojennej polszczyzny mówionej zajmowała się także Krystyna Pisarkowa w artykule pt. Jak się tytutujemy i zwracamy do drugich ${ }^{39}$. Autorka w swojej pracy pokazuje związki między trzema głównymi czynnikami interakcji społecznej: intymnością, wpływem i integracją

${ }^{32}$ M. Marcjanik, Współczesne polskie toasty-przejawem pauperyzacji życia towarzyskiego, [w:] Język a kultura, t. 5, Potoczność w życiu i kulturze, red. J. Anusiewicz, M. Marcjanik, Wrocław 1992, s. 191-201.

${ }^{33}$ G. Habrajska, Struktura życzeń światecznych, „Poradnik Językowy” 1993, z. 7, s. 384-396.

${ }^{34}$ Z. Kaczyński, Miejsce pozdrowień wśród wypowiedzi językowych, „Acta Universitatis Wratislaviensis" 1983, Folia Linguistica 8, s. 21-31.

35 J. Grosse, Pan, ty, czy wy, Kraków 1906.

${ }^{36}$ A. Brückner, Ty - Wy - Pan. Kartka z dziejów próżności ludzkiej, Kraków 1916.

37 J. Łoś, Od ty do pan, „Język Polski” 1916, R. III, s. 1-10.

38 Z. Klemensiewicz, Pan i obywatel, „Język Polski” 1946, R. XXVI, s. 33-42.

${ }^{39}$ K. Pisarkowa, Jak się tytułujemy i zwracamy do drugich, ,Język Polski” 1979, R. LIX, s. 5-16. 
oraz ich oddziaływanie na sposób zwracania się do rozmówcy. O przeobrażeniach dotyczących adresatywów pisze też Antonina Grybosiowa w artykule Przyczyny zmian w polskim systemie adresatywnym ${ }^{40}$. Badaczka stwierdza, że dawniej ty wyrażało władzę osoby, która tej formy używała, natomiast pan(i) było formą integrująca, oznaką przynależności do pewnej elity ${ }^{41}$. Zagadnieniom stosowania tych zaimków poświęcony jest też inny artykuł A. Grybosiowej: Formy ty i pan w kontaktach społecznych $h^{42}$. Natomiast o tendencji do zastępowania na wsi tradycyjnych formuł pluralis maiestaticus zwrotami pan, pani, państwo pisze Kazimierz Sikora w pracy Jak pan zawędrowat na wieś ${ }^{43}$. Zagadnieniom współcześnie używanych form adresatywnych, z uwzględnieniem aspektu socjolingwistycznego, poświęcone są także artykuły Jana Miodka Jeszcze o sposobach zwracania się do drugich ${ }^{44}$ oraz Danuty Buli O sposobach zwracania się do rozmówcy ${ }^{45}$.

Wreszcie warto wspomnieć o książce Marka Łazińskiego pt. O panach $i$ paniach. Polskie rzeczowniki tytularne i ich asymetria rodzajowo-ptciowa ${ }^{46}$. Pierwsza część pracy została poświęcona polskim zwrotom adresatywnym i tytułom, natomiast druga to krótki zarys dziejów kształtowania się polskiego i słowiańskiego systemu rodzajów. Celem autora było opisanie dwóch zjawisk we współczesnej polszczyźnie, które często są przyczyną psychologicznej interpretacji systemu językowego. Chodzi tu po pierwsze o luki rodzajowe, które bywają interpretowane jako dowód nierównego traktowania płci, a po drugie o zaimki pan, pani, które z kolei często są uważane za przejaw polskiej tytułomanii.

\section{Prace dotyczące dawnej etykiety językowej}

Problematyka dotycząca dawnej etykiety językowej jest opracowana zdecydowanie słabiej. Największym zainteresowaniem badaczy cieszą się formuły nominalne, szczególnie adresatywy. Bardzo nieliczne prace podejmują tematykę formuł werbalnych. Należy tu wymienić przede wszystkim artykuły Marka

${ }^{40}$ A. Grybosiowa, Przyczyny zmian $w$ polskim systemie adresatywnym, [w:] Język w mieście. Problemy kultury i poprawności, red. K. Michalewski, „Acta Uniwersitatis Lodziensis” 1998, Folia Linguistica" 37, s. 57-61.

${ }^{41}$ R. Brown, A. Gilman, The Pronouns of Power and Solidarity, [w:] Style in Language, ed. T. Sebeok, Boston 1960, s. 253-276.

${ }^{42}$ A. Grybosiowa, Formy ty i pan w kontaktach społecznych, „Poradnik Językowy” 1990, z. 2, s. $88-92$.

${ }^{43}$ K. Sikora, Jak pan zawędrowat na wieś, „Język Polski” 1993, R. LXXIII, s. 298-307.

${ }^{44}$ J. Miodek, Jeszcze o sposobach zwracania się do drugich, „Język Polski” 1980, nr 60, s. $177-179$.

${ }^{45}$ D. Bula, O sposobach zwracania się do rozmówcy, „Prace Naukowe Uniwersytetu Śląskiego w Katowicach” 1985, Prace Językoznawcze 10, s. 110-123.

${ }^{46} \mathrm{M}$. Łaziński, O panach i paniach. Polskie rzeczowniki tytularne i ich asymetria rodzajowo-ptciowa, Warszawa 2006. 
Cybulskiego poświęcone aktom grzecznościowym doby staropolskiej i średniopolskiej: Polskie formuly powitalne od XVI do połowy XVIII wieku ${ }^{47}$, Polskie formuly toastu do XVIII w..$^{48}$, Polskie formy rozkazu i zakazu do połowy XVIII w. ${ }^{49}$, Staropolskie formy podziękowañ ${ }^{50}$. Najobszerniejszą pracą z tego zakresu jest monografia M. Cybulskiego pt. Obyczaje językowe dawnych Polaków. Formuly werbalne $w$ dobie średniopolskiej ${ }^{51}$. Autor przedstawia w niej autonomiczne akty etykiety zarówno ustne, jak i pisemne, szablonowe i nieszablonowe. Szczególny nacisk położony został na pragmatyczny i socjolingwistyczny aspekt analizy zgromadzonego materiału.

O nieco późniejszych aktach grzecznościowych pisze Elżbieta Umińska-Tytoń w pracy pt. Polszczyzna dziewiętnastowiecznych salonów ${ }^{52}$. W rozdziale poświęconym wykładnikom etykiety językowej znajdujemy informacje o adresatywach, formach nazywających osobę trzecią a także o najlepiej poświadczonych w źródłach, wybranych formułach werbalnych, których używały w badanym okresie wyższe warstwy społeczne. Autorka omawia również stosowane w środowisku szlachty i arystokracji strategie grzecznościowe.

Formułom werbalnym poświęcony jest też artykuł Leszka Moszyńskiego pt. Biblijne pozdrowienia w przekładach stowiańskich ${ }^{53}$.

Pozostałe prace skupiają uwagę głównie na formułach nominalnych. Początek zainteresowania nimi obserwujemy w artykule Mariana Chmielowca pt. Aścka i inne tytuly staropolskie ${ }^{54}$, który przedstawia propozycję gimnazjalnej lekcji na temat dawnych form adresatywnych.

O szlacheckiej etykiecie językowej widzianej przez pryzmat form adresatywnych i tytulatury traktuje artykuł Marii Wojtak pt. Staropolska etykieta językowa jako obraz relacji międzyludzkich ${ }^{55}$. Autorka dochodzi do wniosku, że rozbudo-

${ }^{47}$ M. Cybulski, Polskie formuly powitalne od XVI do połowy XVIII wieku, „Prace Naukowe Uniwersytetu Śląskiego" 1996, Prace Językoznawcze 24, s. 27-37.

${ }^{48}$ M. Cybulski, Polskie formuty toastu do XVIII w., [w:] Kultura ubóstwa - kultura przetrwania, red. D. Zalewska, Wrocław 1996, s. 65-72.

${ }^{49}$ M. Cybulski, Polskie formy rozkazu i zakazu do połowy XVIII w., [w:] Regulacyjna funkcja tekstów, red. K. Michalewski, Łódź 2000, s. 11-24.

${ }^{50}$ M. Cybulski, Staropolskie formy podziękowań, [w:] Od średniowiecza ku wspótczesności. Prace ofiarowane Jerzemu Starnawskiemu w pięćdziesięciolecie doktoratu, red. J. Okoń, Łódź 2000, s. 105-114.

${ }^{51}$ M. Cybulski, Obyczaje językowe dawnych Polaków. Formuly werbalne w dobie średniopolskiej, Łódź 2003.

52 E. Umińska-Tytoń, Polszczyzna dziewiętnastowiecznych salonów, Łódź 2011, s. 109-179.

${ }^{53}$ L. Moszyński, Biblijne pozdrowienia w przekładach słowiańskich, [w:] Inspiracje chrześcijańskie w kulturze Europy, red. E. Woźniak, Łódź 2000, s. 169-184.

${ }_{54}$ M. Chmielowiec, Z życia wyrazów:Aśćka i inne tytuły staropolskie (Przykład lekcji w klasie V gimnazjalnej), ,Język Polski” 1924, R. IX, s. 17-22.

${ }_{55}$ M. Wojtak, Staropolska etykieta językowa jako obraz relacji międzyludzkich (Wybrane zagadnienia), [w:] Przeszłość w językowym obrazie świata, red. A. Pajdzińska, P. Krzyżanowski, Lublin 1999, s. 205-216. 
wana tytulatura to nie wynik szlacheckiej tytułomanii, ale sposób na wieloaspektowe wyrażenie relacji między nadawcą a odbiorcą wypowiedzi.

Warta uwagi jest też seria artykułów Geralda Stone'a podejmująca zagadnienia przemian zachodzących w adresatywach doby staropolskiej i średniopolskiej. Najstarszym sposobom zwracania się do rozmówcy poświęcona została praca pt. Grzecznościowe formy adresatywne w języku polskim przed 1600 rokiem $^{56}$. W kolejnej pt. Polskie zaimki adresatywne $w$ siedemnastym wieku ${ }^{57}$ omawia przede wszystkim przekształcenia, którym ulegał zwrot wasza miłość. Natomiast w ostatnim z cyklu artykułów pt. Formy adresatywne języka polskiego w osiemnastym wiek $u^{58}$ przedstawia przyczyny wzrostu liczby zaimków adresatywnych 2. osoby na przełomie XVII/XVIII wieku.

Osiemnastowiecznymi sposobami zwracania się do rozmówcy zajmowała się także M. Wojtak w pracy pt. „O polityce w stowiech”. Formy adresatywne $w X V I I I$ wiek $u^{59}$. Autorka wymienia repertuar form używany w sytuacji rozmowy $\mathrm{z}$ nieznajomymi, w kontaktach towarzyskich, rodzinnych, z osobami duchownymi. Omawia także relację pan - sługa. Podkreśla, że rzeczywiste społeczne odniesienia między panem a sługą mogły mieć różnoraki charakter.

O relacji sługi do pana pisze również M. Cybulski w artykule Pan i stuga. Niektóre społeczne uwarunkowania zmian w polskich obyczajach językowych ${ }^{60}$. Autor stwierdza, że od XVI do XVIII wieku nie zaszedł żaden przełomowy fakt, który znacząco zmieniłby językowy obraz tej relacji. Zmiany przyniosła dopiero druga połowa XIX wieku, gdy zanikają etykietalne formuły typu stużby zalecam, stuga uniżony, a upowszechniają się pan, pani +3 . osoba czasownika. Przyczyną tej ewolucji były zmiany społeczne związane z upadkiem Rzeczpospolitej, kiedy to zanika klientela magnacka. Ważną rolę odegrała także urbanizacja i migracja chłopów oraz wpływ idei demokratycznych. Pan zaczął funkcjonować jako zaimek, gdy tkwiąca w dawnej etykiecie językowej relacja pan - sługa przestała istnieć.

Kolejny artykuł M. Cybulskiego $Z$ historii polskich form adresatywnych. „Waszeć" w XVII i XVIII wieku ${ }^{61}$ pokazuje jak tytułowa forma zmieniała swój

${ }^{56}$ G. Stone, Honorific Pronominal Address in Polish Before 1600, „Oxford Slavonic Papers” 1984, New Series XVII, s. 45-56.

${ }^{57}$ G. Stone, Polish Pronominal Address in the Seventeenth Century, „Oxford Slavonic Papers” 1985, New Series XVII, s. 55-66.

${ }_{58}$ G. Stone, Formy adresatywne języka polskiego w osiemnastym wieku, „Język Polski” 1989, R. LXIX, s. 135-142.

${ }^{59}$ M. Wojtak, „O polityce $w$ stowiech”. Formy adresatywne w XVIII wieku, „Język Polski” 1996, R. LXXVI, s. 81-87.

${ }^{60}$ M. Cybulski, Pan i stuga. Niektóre społeczne uwarunkowania zmian w polskich obyczajach językowych. [w:] Uwarunkowania i przyczyny zmian językowych. Zbiór studiów, red. E. Wrocławska, Warszawa 1994, s. 31-39.

${ }^{61}$ M. Cybulski, Z historii polskich form adresatywnych. „Waszeć” w XVII i XVIII wieku, [w:] Spotkanie. Księga Jubileuszowa dla Profesora Aleksandra Wilkonia, red. M. Kita, B. Witosz, Katowice 2005, s. 459-473. 
społeczny zakres użycia. Proces skracania adresatywów przedstawił M. Cybulski w pracy pt. Skrócenia $w$ dawnych polskich formach adresatywnych ${ }^{62}$. Natomiast formy autoadresatywne są przedmiotem artykułu pt. O staropolskich $i$ średniopolskich zwyczajowych określeniach nadawcy wypowiedzi ${ }^{63}$.

Inna praca poświęcona dawnym sposobom zwracania się do odbiorcy to artykuł M. Rachwał pt. Formy adresatywne w mowach staropolskich ${ }^{64}$. Materiał językowy został zaczerpnięty z kazań i mów sejmowych, sądowych i okolicznościowych powstałych od XVI do końca XVIII wieku. Autorka przedstawia użycie adresatywów w aspekcie układu ról, jakie zajmują partnerzy w procesie komunikacji.

Dawnej pragmatyce tytularnej poświęcony jest też artykuł M. Wojtak Grzeczność po staropolsku w świetle „Pamiętników” Jana Chryzostoma Pa$s k a^{65}$. Autorka zajmuje się w nim czasownikowymi formami trybu rozkazującego i towarzyszącą im tytulaturą. Do dawnych zapisków odwołuje się również w swoim artykule Formuły grzecznościowe w osiemnastowiecznych diariuszach E. Umińska-Tytoń ${ }^{66}$. Analizowany materiał pochodzi z Itinerarium Jakuba Lanhausa z 1768 roku. Autorka omawia zakres używania występujących w tekście adresatywów i dochodzi do wniosku, że rozbudowywaniu formuł grzecznościowych nie sprzyjał prywatny charakter tekstu. W nieoficjalnym diariuszu tytulatura została ograniczona do elementów niezbędnych do ukazania stosunku między rozmawiającymi.

Z kolei praca D. Dykiel Formy adresatywne w ,Wydwornym polityku M. Guthëtera-Dobrackiego" ${ }^{67}$ ukazuje system adresatywny siedemnastowiecznej polszczyzny mówionej na podstawie podręcznika do nauki języka i obyczajów polskich przeznaczonego dla niemieckich mieszczan.

Ciekawą analizę użycia adresatywów znajdziemy też w artykule Haliny Safarewiczowej pt. Tytuty grzecznościowe $w$,Panu Tadeuszu”68 . Autorka zauważa, że zewnętrznym sygnałem obniżania rangi poszczególnych tytułów było skracanie ich brzmienia. W końcu XVIII wieku stosowanie tradycyjnej tytulatury było

${ }^{62}$ M. Cybulski, Skrócenia $w$ dawnych polskich formach adresatywnych, „Rozprawy Komisji Językowej Łódzkiego Towarzystwa Naukowego" 2004, R. XLIX, s. 98-109.

${ }^{63} \mathrm{M}$. Cybulski, O staropolskich i średniopolskich zwyczajowych określeniach nadawcy wypowiedzi, Studia Historycznojęzykowe, t. I, red. M. Kucała i Z. Krążyńska, Kraków 1994, s. 201-208.

${ }^{64}$ M. Rachwał, Formy adresatywne w mowach staropolskich, „Poradnik Językowy” 1987, z. 7 , s. $528-535$.

${ }^{65}$ M. Wojtak, Grzeczność po staropolsku w świetle „Pamiętników” Jana Chryzostoma Paska, „Poradnik Językowy” 1989, z. 8, s. 528-533.

${ }^{66}$ E. Umińska-Tytoń, Formuly grzecznościowe w XVIII-wiecznych diariuszach, „Rozprawy Komisji Językowej Łódzkiego Towarzystwa Naukowego" 1992, R. XXXVII, s. 139-144.

${ }^{67}$ D. Dykiel, Formy adresatywne w , Wydwornym polityku M. Guthëtera-Dobrackiego”, ,Rozprawy Komisji Językowej Wrocławskiego Towarzystwa Naukowego" 1989, t. XVI, s. 147-161.

${ }^{68}$ H. Safarewiczowa, Tytuly grzecznościowe w „Panu Tadeuszu”, [w:] W stużbie nauce i szkole. Księga pamiatkowa poświęcona prof. doktorowi Z. Klemensiewiczowi, Warszawa 1970, s. 267-275. 
wciąż jeszcze żywe, zwyczaj ten zanika około połowy XIX wieku. Zdaniem Safarewiczowej język dzieła Mickiewicza znajduje się pomiędzy tymi punktami.

Analizie adresatywów w dziełach literackich poświęcone są też prace: Tytulatura Sebastiana Klonowica (1545-1602) H. Wiśniewskiej ${ }^{69}$, Formy adresatywne w „Polskiej Komedii Rybałtowskiej” K. Szczypki ${ }^{70}$, Sposoby zwracania się do rozmówcy w „Pamiqtkach Soplicy” Henryka Rzewuskiego (Szkic z pragmatyki historycznej) B. Bartnickiej ${ }^{71}$, Podstawowe honorativa we wczesnych komediach Aleksandra Fredry T. Brajerskiego ${ }^{72}$ oraz „Panie Wokulski”, czyli o pewnym typie form adresatywnych w ,Lalce” Bolestawa Prusa M. Rachwał ${ }^{73}$.

$\mathrm{Na}$ koniec warto wspomnieć o pracy Katarzyny Mroczek pt. Tytulatura w korespondencji staropolskiej jako problem stosunku między nadawcq a odbiorca ${ }^{74}$. Materiałem badawczym była tu prywatna korespondencja osób świeckich z XVI-XVIII wieku, a także pochodzące $\mathrm{z}$ tego okresu listowniki. Mroczek zajmowała się tylko tymi formami adresatywnymi, które występowały w adresie, nagłówku i podpisie. Autorka po skonfrontowaniu wskazówek zawartych w podręcznikach z istniejącą korespondencją dochodzi do wniosku, że chociaż badane listy zwykle potwierdzają znajomość norm, to w praktyce były one często przekraczane lub modyfikowane.

Porównaniem podręcznikowych zasad z epistolarną praktyką zajęła się również Ewa Miozga w pracy Osiemnastowieczne listowniki. Teoria i praktyka ${ }^{75}$.

Zaprezentowany tu przegląd literatury pokazuje, że w odniesieniu do początków doby nowopolskiej problematyka dotycząca obyczajowości językowej Polaków nie została dotąd zanalizowana w sposób całościowy. Większość przedstawionych tu prac opisuje wycinkowo jednostkowe teksty lub jednostkowe zjawiska.

${ }^{69}$ H. Wiśniewska, Tytulatura Sebastiana Klonowica (1545-1602), „Język Polski” 1982, R. LXII, s. 3-11.

${ }^{70}$ K. Szczypka, Formy adresatywne w „, Polskiej Komedii Rybaltowskiej”, „,Rozprawy Komisji Językowej Wrocławskiego Towarzystwa Naukowego" 1989, t. XVI, s. 163-188.

${ }^{71}$ B. Bartnicka, Sposoby zwracania się do rozmówcy w ,Pamiatkach Soplicy” Henryka Rzewuskiego (Szkic z pragmatyki historycznej), „Poradnik Językowy” 1989, z. 5, s. 276-284.

72 T. Brajerski, Podstawowe honorativa we wczesnych komediach Aleksandra Fredry, ,Roczniki Humanistyczne" 1995, z. 6: Językoznawstwo, t. XLIII, s. 5-70.

${ }^{73}$ M. Rachwał, ,Panie Wokulski”, czyli o pewnym typie form adresatywnych $w$ „,Lalce” Bolestawa Prusa, „Prace Językoznawcze” 1991, nr 6, s. 227-236.

${ }^{74}$ M. Mroczek, Tytulatura $w$ korespondencji staropolskiej jako problem stosunku między nadawcq a odbiorca, „Pamiętnik Literacki” 1978, z. 69, s. 127-148.

${ }^{75}$ E. Miozga, Osiemnastowieczne listowniki. Teoria i praktyka, Katowice 2000. 


\section{POWITANIA I FORMULY INICJALNE W LISTACH}

Powitanie jest aktem mowy, który pełni przede wszystkim funkcję fatyczną ${ }^{1}$ - pozwala nawiązać kontakt oraz sygnalizuje, że nadawca dostrzega odbiorcę 2 . Postać tej formuły grzecznościowej może już we wstępnej fazie interakcji informować o rangach pragmatycznych interlokutorów oraz o ich miejscu w hierarchii społecznej3.

W epoce staropolskiej formuły werbalne w epistolarnej salutacji były rzadkością ${ }^{4}$ Zazwyczaj inicjowano kontakt za pomocą mniej lub bardziej rozbudowanych form adresatywnych. Listowniki początku doby nowopolskiej najczęściej również zalecały ich stosowanie, choć M. Korzeniowski pisał, że: „wstęp nie jest rzeczą tak istotną żeby się list bez niego, zwłaszcza do poufałych i przyjaciół, obejść nie móg15". Materiał pokazuje, że w badanym okresie zdecydowanie najczęściej funkcję salutacji pełniły formy adresatywne. Zdarza się jednak, że rolę powitania przejmują formuły werbalne, zwykle charakterystyczne dla kontaktów bezpośrednich.

W badanym materiale możemy wyróżnić ze względu na strukturę składniową i właściwości morfologiczne czasownika trzy typy formuł powitalnych:

1.1. Formuly pochodzące od fraz zawierających 2. lub 3. osobę trybu rozkazującego,

1.2. Formuły pochodzące od fraz zawierających 1 . osobę trybu oznajmującego,

1.3 Pytania powitalne. s. 39 .

${ }^{1}$ A. Awdiejew, G. Habrajska, Wprowadzenie do gramatyki komunikacyjnej, t. 1, Lask 2004,

${ }^{2}$ Według M. Marcjanik ogólne treści przekazywane przez nadawcę podczas powitania, to: „Mówię, że widzę cię, wyodrębniam cię z tła innych osób” lub (jeśli interakcja nie jest ograniczona do aktu powitania) „Mówię, że rozpoczynam kontakt z Tobą”. M. Marcjanik, Polska grzeczność językowa, Kielce 2000, s. 13.

${ }^{3}$ S. Grabias, Jezzyk w zachowaniach społecznych, Lublin 2001, s. 278.

${ }^{4}$ M. Cybulski, Obyczaje językowe dawnych Polaków. Formuly werbalne w dobie średniopolskiej, Łódź 2003, s. 17.

${ }^{5}$ M. Korzeniowski, Nowy sekretarz powszechny: ksiażka podręczna dla osób każdego stanu zawierajaca: wybór wzorowych listów we wszystkich stosunkach i okolicznościach potocznego życia, wybranych z dzieł najnowszych autorów, wraz z uwagami o listach, tudzież o sposobie pisania samemu w różnych materyach; Wzory przedstawień do władz rzqdowych, wekslów, obligów, kontraktów, cessyi, testamentów, rozmaitych zapisów, zaświadczeń, wszelkich aktów urzędowych i. t. p. $z$ dołaczeniem krótkich obiaśnień nad temiż, Wrocław 1843, s. 4. 


\subsection{FORMUŁY POCHODZĄCE OD FRAZ ZAWIERAJĄCYCH 2. LUB 3. OSOBĘ TRYBU ROZKAZUJACCEGO}

\subsection{1. „witaj” i przekształcenia}

\subsubsection{1. „witaj”}

Powitanie to jest prawdopodobnie najstarsze ${ }^{6} \mathrm{i}$ w tej pierwotnej postaci występuje w badanym okresie dość rzadko. O ile jądrem większości grzecznościowych formuł werbalnych są czasowniki performatywne, to w przypadku witaj pojawia się czasownik perlokucyjny - czyli wskazujący na skutek, który wywołuje akt mowy ${ }^{7}$. Wynika to zapewne z faktu, że jak podaje A. Brückner, zawitać znaczyło pierwotnie „przybyć na pobyt, mieszkanie ${ }^{8 ”, ~ z a t e m ~ g e n e t y c z n i e ~ b y ł o ~}$ to zaproszenie i dlatego za pomocą tej formuły zwracał się gospodarz do gościa. $\mathrm{W}$ początkach doby nowopolskiej zasada ta nie była przestrzegana ${ }^{9}-\mathrm{z}$ badanego materiału wypływa wniosek, że akt ten nie funkcjonował już wyłącznie jako specjalny sposób witania przybysza, ale również jak każde inne powitanie - nie było ograniczeń w jego stosowaniu.

$\mathrm{Z}$ analizowanych tekstów wynika, że witaj pojawiało się we wszystkich warstwach społecznych - od sług do króla, ale jedynie wtedy, gdy nadawca posiadał równą lub wyższą rangę pragmatyczną od odbiorcy. Jest to prawdopodobnie konsekwencja faktu, że jak pisze M. Cybulski, formuła ta już w okresie średniopolskim była społecznie zdeprecjonowana ${ }^{10}$. Najczęściej przykłady jej zastosowania obserwujemy jednak w relacjach symetrycznych:

Witaj, pożądany Świstaku (sługa do sługi, lata 80. XVIII w.) ZabF 27;

A witajcież! witajcież (młynarzowa do chłopów, kon. XVIII w.) BoCu 140;

A witajże, witaj, kochany panie sąsiedzie (starosta do szlachcica, I poł. XIX w.) SkarbSt 17;

Witajcież mi panowie na tem miejscu ${ }^{11}$ (szlachcic do znajomych, I poł. XIX w.) SkarbDod 25;

A witajże panie bracie (starościc do szlachcica, I poł. XIX w.) SkarbDod 22 ;

${ }^{6}$ M. Cybulski, Obyczaje językowe..., s. 18.

${ }^{7}$ R. Grzegorczykowa, Wprowadzenie do semantyki językoznawczej, Warszawa 2001, s. 30. oraz E. Grodziński, O czasownikach perlokucyjnych, „Poradnik Językowy” 1981, z. 4, s. 181-187.

${ }^{8}$ A. Brückner, Stownik etymologiczny języka polskiego, Warszawa 1989, s. 625.

${ }^{9}$ Według ustaleń M. Cybulskiego już na początku XVII w. zasada ta bywała łamana. M. Cybulski, Obyczaje językowe..., s. 20.

10 Ibidem, s. 18.

${ }^{11}$ Umiejscawiające wyrażenie przyimkowe jest tu być może nawiązaniem do pierwotnego znaczenia ,przebywać”. 
Witajcie! szanowni i kochani sąsiedzi (szlachcic do sąsiadów, poł. XIX w.) DmNa 44;

Witaj, panie wędrowcze (szlachcianka do przyjaciela wracającego z podróży, poł. XIX w.) ŻmPow2, 91.

Nieliczne są przykłady użycia witaj w relacji asymetrycznej:

Witaj między nami i bądź posiedzeń czwartkowych ozdobą (król Stanisław August Poniatowski do poety - gościa obiadów czwartkowych, II poł. XVIII w.) TańList 127 - w tym wypadku zwykłe witaj nabiera w ustach króla uroczystego charakteru, jest niejako aktem przyjęcia do ścisłego grona bliskich władcy literatów.

Witaj, panie sędzio (hetman wielki koronny, lata 80. XVIII w.) KoźPam 104;

Witajże, witaj (szlachcic do Żyda lata 40. XIX w.) DzierzDz 83.

Jedyny ślad użycia witaj w stosunku do osoby o wyższej randze to powitanie skierowane przez szlachciankę do krewnego: Witajże, wuju! (poł. XIX w.) ŁozCh1, 128. Choć młoda kobieta miała niewątpliwie niższy status społeczny i rodzinny od swojego krewnego, to jednak łączące ich bliskie stosunki prawdopodobnie czyniły tę różnicę mało istotną. Jak zauważa M. Wojtak ${ }^{12}$, aby odtworzyć obraz dawnych relacji międzyludzkich, który jest zawarty w językowych wykładnikach etykiety, nie można poprzestać na wyłącznie socjolingwistycznym rozumieniu pojęcia ranga, które jest określane przez relacje równorzędności, podrzędności lub nadrzędności nadawcy względem odbiorcy wypowiedzi. Wyróżnikiem tych parametrów jest bowiem tylko stosunek ról społecznych, natomiast zachowania etykietalne są związane również z wyodrębnianiem rangi towarzyskiej i konkretną sytuacją porozumiewania się. Symetryczność lub niesymetryczność relacji jest bardziej związana tutaj z rolami komunikacyjnymi niż społecznymi.

W zaprezentowanych formulach elementy obudowy etykietalnej to przede wszystkim adresatywy w wołaczu oraz niezbyt liczne formy atrybutywne, wartościujące pozytywnie odbiorcę i podkreślające radość ze spotkania. Dość często obserwujemy podwajanie członu werbalnego oraz dodawanie partykuł wzmacniających $-\dot{z}$ lub $-\dot{z} e$. Zabiegi te miały zapewne zwiększyć grzeczność prostego powitania. Samo witaj, choć najczęściej kierowane do równych sobie, najwyraźniej uchodziło za zbyt mało uprzejme - szczególnie w sytuacji używania tej formuły zgodnie z jej pierwotnym przeznaczeniem, a więc kiedy gospodarz witał gościa.

${ }^{12}$ M. Wojtak, Staropolska etykieta językowa jako obraz relacji międzyludzkich (wybrane zagadnienia), [w:] Przeszłość w językowym obrazie świata, red. A. Pajdzińska, P. Krzyżanowski, Lublin 1999, s. 205-216. 


\subsubsection{2. ,witam”}

\subsection{W rozmowach}

Czasownik performatywny ${ }^{13}$ witaj w połowie XVI w. ${ }^{14}$ uległ przekształceniu w illokucyjny i przybrał formę 1 . osoby. W badanym okresie witam pojawia się zdecydowanie częściej niż witaj. Performatyw ten, podobnie jak witaj, stosowany był w relacji symetrycznej lub gdy nadawca posiadał wyższy status od odbiorcy. W ekscerpowanych tekstach nie zostały w ogóle poświadczone użycia witam w sytuacji, gdy ranga pragmatyczna nadawcy była niższa od adresata.

Najczęściej za pomocą witam inicjowano rozmowę wtedy, gdy interlokutorzy zajmowali zbliżone miejsca w hierarchii społecznej. Użycie jedynie czasownika performatywnego bez żadnej obudowy etykietalnej, podobnie jak w przypadku witaj, uchodziło najwyraźniej za mało uprzejme, gdyż w analizowanym materiale tylko raz spotykamy samo witam (poł. XIX w.) FrDz1, 60. W ten sposób zwrócił się szlachcic do przyjaciela w sytuacji konfliktu i był to zapewne czynnik, który wpłynął na wyjątkowo krótką postać formuły powitalnej.

Sposobem na zwiększenie uprzejmości pozbawionego dodatków leksykalnych performatywu było powtórzenie go:

Witam, witam (ksiądz do szlachciców, poł. XIX w.) KraszDwa 195;

Witam, witam, cóż tam słychać, jakże idą zajęcia? (adwokat do komornika lata 30. XIX w.) BogA 27 - w tym przypadku formuła została dodatkowo rozbudowana o pytania powitalne wyrażające zainteresowanie interlokutorem.

Zwykle jednak witam łączono z formami adresatywnymi w bierniku, którym często towarzyszyły dodatkowo przymiotniki i zaimki dzierżawcze:

Witam moich kochanych przyjaciół (starosta do szlachty, II poł. XVIII w.) BohK 2, 311;

Witam jegomość pana pułkownika (szlachic, II poł. XVIII w.) BohK2, 48;

Witamy imć pana Łykaczewskiego (szlachic do szlachcica, II poł. XVIII w.) BohK2, 288;

Witam waszmość pana z podróży i mocno się cieszę, że go zdrowego oglądam (podstoli do szwagra, II poł. XVIII w.) BDr 60;

Mojego witam dobrodzieja (przyjaciel do przyjaciela, lata 80. XVIII w.) ZabF 49;

Witamy gości do nas (młynarz do górali, kon. XVIII w.) BoCu 78;

Witam łaskawą panią (Dmochowski do starościny, I poł. XIX w.) DmochWsp 193;

${ }^{13}$ O czasownikach performatywnych E. Grodziński, Niezwykte wtaściwości zwyktych czasowników, „Poradnik Językowy” 1978, z. 2, s. 45-53.

${ }^{14}$ M. Cybulski, Obyczaje językowe..., s. 18. 
Witam kochanego pana (adwokat do zamożnego mieszczanina, wchodząc do jego domu, I poł. XIX w.) DzierzS 12;

Witam ciebie jak synowa (podstolina do rejenta, I poł. XIX w.) FrDz2, 85;

Witam Regenta (bankier do przyjaciela, I poł. XIX w.) KorzDram 75;

A więc kolegę witam (lekarz do kolegi, poł. XIX w.) KraszDz 105;

Witam kochanego pana Franciszka (redaktor do publicysty, lata 30. XIX w.) WójK s.61.

Pojawiają się również formuly, w których dodatkowo podwojony został element werbalny:

Witam, witam Panie i Panów (generałowa do towarzystwa, I poł. XIX w.) KorzWd 116;

Witamy, witamy szanownego obywatela (emigranci paryscy do prezesa Izby Obrachunkowej, lata 30. XIX w.) JanAu 533;

A! witamy! witamy pana! (szlachta do nieobecnego wcześniej na przyjęciu gospodarza, poł. XIX w.) KraszDwa 294.

Elementem obudowy mógł być także konwencjonalny przysłówek lub wyrażenie przyimkowe:

Pożądanego witam gościa serdecznie (szlachcianka do szlachcica, który przyszedł do niej na kawę, lata 70. XVIII w.) KomCzar 350;

Witamy cię, panie Karolu, witamy serdecznie (pułkownik do lekarza, I poł. XIX w.) KorzKom 119;

Z radością witam generała po szczęśliwej przeprawie pośród nieprzyjaciół (generał, 1831) PamGaj 147.

Innym sposobem amplifikowania aktu powitalnego było dodawanie formy wokatywnej obok biernikowego adresatywu:

Witam pana, panie Wojewodzicu (starościna, I poł. XIX w.) KorzKom s.178;

Witam cię, zacny starcze i jesteś u mnie szacownym gościem (kasztelanowa do urzędnika, I poł. XIX w.) KorzDram 75;

Witam cię więc w moim domu, kochana żono (hrabia do świeżo poślubionej małżonki, I poł. XIX w.) KorzDram 312;

Witam was, panie bracie (szlachcic do szlachcica, I poł. XIX w.) SkarbDod 90;

O kochany Wacławie! witam cię (adwokat do przyjaciela, lata 30. XIX w.) BogA 46.

W przypadku, gdy za pomocą witam zwracano się do osoby o niższej randze, obudowa etykietalna była skromniejsza i zwykle sprowadzała się do biernikowych form adresatywnych:

Witam was, panowie (baron do młodych szlachciców, II poł. XVIII w.) SchSt 37;

Witamy gościa z Puław (gospodyni do ogrodnika, II poł. XVIII w.) KniaźDram 177;

A, witamy pana w naszym domu (kasztelanowa do guwernera, kon. XVIII w.) SkarSegl 19; 
Witam was, moje dzieci (młynarz do dzieci chłopów, kon. XVIII w.) BoCu 55; Witam panie kollego (podoficer do żołnierza, lata 20. XIX w.) PawEd 46;

Witam szanowną gosposię (arystokrata do właścicielki kawiarni lata 40 . XIX w.) RusWar4, 84;

Witamy cię Lucyanku (szlachcianka do siostrzeńca, poł. XIX w.) BujSt 40;

Witamy panią w naszym ubogim domku (szlachcianka do guwernatki, poł. XIX w.) DmNa 186.

W pojedynczych aktach pojawiają się inne elementy obudowy takie jak formy atrybutywne: Witam szanowną panią (szlachcic do sędziny, I poł. XIX w.) KorzKom 344; Witamy panią serdecznie (szlachcic do córki leśniczego, lata 60. XIX w.) CieszP 136; wyrażenia okolicznikowe: Witamy z podróży (wuj do siostrzeńca, I poł. XIX w.) FrDz1, 321; czy pytania powitalne Witam księdza brata, a jakże ze zdrowiem? (generał do zakonnika, II poł. XVIII w.) RzewLis1, 221.

W cytowanych przykładach witam często jest aktem etykietalnym, który służy do nawiązania kontaktu gospodarza z gościem, zatem czasownik performatywny w dużej mierze kontynuuje funkcje perlokucyjnego witaj. Badany materiał pokazuje jednak, że, podobnie jak w przypadku witaj, użycie witam nie było ograniczone sytuacyjnie i możliwe było zastosowanie tej formuły jako zwykłego powitania podczas spotkania znajomej osoby.

W dobie średniopolskiej witam było wyżej wartościowane niż witaj, gdyż forma ta była dziełem szlachty i w związku z tym chętnie stosowano ją podczas uroczystych oracji powitalnych ${ }^{15}$. W badanym okresie również znajdujemy przykład takiego użycia:

Witam waszeciów mościwych panów i braci na tym elektoralnym polu KitPam 145 — w ten sposób miał się zwrócić prymas do szlachty podczas sejmu elekcyjnego w $1764 \mathrm{r}$.

\subsection{W listach}

Taka salutacja w korespondencji spotykana jest bardzo rzadko, a jej użycie uwarunkowane konkretnymi okolicznościami:

Witam Panią moją szczęśliwie do nas przybyłą (1795) SzymLis s.78 - pisał arystokrata w liście do przyjaciółki, ciesząc się z jej powrotu do kraju i prawdopodobnie stąd wybór takiej formuły powitalnej.

Narcyza Żmichowska rozpoczęła list do brata słowami:

Witam cię życzeniem Świąt lepszych trochę jak te, na które u nas się zanosi (1862) ŻmLis s.185. - formuła ta jest połączeniem powitania i nietypowych świątecznych życzeń.

\footnotetext{
${ }^{15}$ M. Cybulski, Obyczaje językowe..., s. 21.
} 


\subsubsection{3. „mam honor witać/przywitać” i przekształcenia}

Zarówno witaj, jak i późniejsze witam były formułami, których w zasadzie nie używano w relacji asymetrycznej, gdy osoba o niższym statusie zwracała się do wyżej postawionej. W takich sytuacjach mogła pojawić się rozbudowana honoryfikatywna ${ }^{16}$ fraza werbalna mam honor witac ${ }^{17}$ (lub z czasownikiem w aspekcie dokonanym przywitać), która wyrażała wyższy stopień grzeczności. Tę dość ceremonialnę formułę spotykamy w badanych tekstach rzadko:

Mam honor witać imci pana Figlackiego (przyjaciel do guwernera, poł. XVIII w.) BohK1, 345;

I ja mam honor witać waszmość pana (szlachcic do szlachcica, poł. XVIII w.) BohK2, 447;

Ale niechże i gospodarza mam honor przywitać (szlachta, poł. XVIII w.) BohK2, 455;

Niespodziewanie mam honor witać tu waszmość pana (szlachta, poł. XVIII w.) BohK2, 311.

Dodatkową funkcję tej konstrukcji możemy zaobserwować w następujących aktach:

Wolnoż mi się w odwet spytać kogom zyskat honor witać? (rejent do nieznajomego, I poł. XIX w.) FrDz2, 77;

Kogóż mam honor witać? (lekarz do nieznajomego, poł. XIX w.) KraszJary 84 .

Powyższe formuły pełnią podwójną funkcję: są nie tylko powitaniem, ale również prośbą o informacje na temat personaliów interlokutora. Nadawcy, nie wiedząc z kim mają do czynienia, na wszelki wypadek używają aktu wskazującego na wyższość odbiorcy.

\subsection{2. „dzień dobry"/,dobry wieczór"}

\subsubsection{W rozmowach}

To powszechnie dziś stosowane ${ }^{18}$ powitanie wywodzi się z formuły o charakterze religijnym, którą można sprowadzić do schematu Bóg (Boże) daj + accusa-

${ }^{16} \mathrm{~W}$ niniejszej pracy odróżnia się pojęcie honoryfikatywności od grzeczności. Grzeczność to element zachowań, na które wpływ mają normy obyczajowe i językowe, natomiast honoryfikatywność jest elementem systemu języka mającym formalne gramatyczne i leksykalne wykładniki (np. tryb przypuszczający czy czasowniki typu pozwól, racz, mam honor). R. Huszcza, Honoryfikatywność. Gramatyka. Pragmatyka. Typologia,Warszawa 2006, s. 47.

${ }^{17}$ Terminu honoryfikatywna fraza werbalna używam za R. Huszczą, ibidem.

${ }^{18}$ M. Marcjanik, Polska grzeczność..., s. 14. 
tivus nazwy miary czasu z przydawką dobry ${ }^{19}$. Genetycznie zatem dzień dobry/ dobry wieczór było modlitewnym życzeniem, którego człon werbalny został zredukowany. W rezultacie powstała formuła niezawierająca ani niedopuszczająca orzeczenia ${ }^{20}$. Proces zmiany szyku przydawki na postpozycyjny rozpoczął się $\mathrm{w}$ drugiej połowie XVII wieku ${ }^{21}$ i obją tylko akt zawierający rzeczownik $d z i e n^{22}$. W ekscerpowanych tekstach rzadko można spotkać tę formułę bez odwróconego szyku. Dobry dzień pojawia się w całym badanym okresie, lecz trudno znaleźć jakąś prawidłowość, która decydowała o jego użyciu.

W pierwszym wieku doby nowopolskiej ten rodzaj powitania występował już tylko w skróconej postaci i był, obok witam, najczęściej spotykanym aktem inicjującym kontakt. Jedyny ślad po zredukowanym orzeczeniu to często pojawiające się formy adresatywne $\mathrm{w}$ dativie, typowe dla okresu, gdy występował jeszcze człon werbalny. Po skróceniu do dzień dobry, obok celownikowych form adresatywnych, zaczęły pojawiać się także wołaczowe.

Podobnie jak dziś, była to formuła bardzo uniwersalna, a jej użycie nie było społecznie ograniczone. W poradniku dobrych manier z 1843 roku czytamy, że: „Dzień dobry panu, pani, pannie itd. bez żadnych innych form i bez żadnych dodatków mówi się tylko osobom niższym i równym; okazać można tę życzliwość i wyższym, ale wtedy tylko gdy jesteśmy z niemi w bliskich stosunkach zażyłości ${ }^{23} "$.

W ekscerpowanych tekstach znajdziemy przykłady powitań, które realizują zaproponowany w poradniku wzorzec:

Dobry wieczór panom (szlachcic do znajomych, I poł. XIX w.) KorzDram 287;

Dobry wieczór panu (drukarz do aplikanta sądowego, ok. 1830) JanAu 160;

Dzień dobry paniom (szlachcic do szlachcianek, poł. XIX w.) CieszT 143;

Dzień dobry pani (hrabia do pianistki, poł. XIX w.) KraszH 273;

Dobry wieczór paniom, dobry wieczór panom (podsędek do mieszczan podczas spaceru, poł. XIX w.) KorzRep 15.

Zwykle jednak w relacji symetrycznej celownikowe formy adresatywne nie ograniczają się do tytulatury standardowej ${ }^{24}$, ale są rozbudowywane o imiona czy formy atrybutywne:

${ }_{19}$ M. Cybulski, Polskie formuly powitalne..., s. 31.

${ }_{20}$ M. Cybulski, O ograniczeniu fleksji w formułach polskiej etykiety językowej, „Rozprawy Komisji Językowej Łódzkiego Towarzystwa Naukowego" 2010, R. LV, s. 55-56.

${ }^{21}$ M. Cybulski, Obyczaje językowe..., s. 27.

${ }^{22}$ Choć w ekscerpowanych tekstach pojawia się raz wieczór dobry RusWar4, 85.

${ }^{23}$ Wychowaniec dziewiętnastego wieku czyli przepisy przystojności i dobrego tonu w pożyciu towarzyskiem, zebrał i według najlepszych wzorów francuzkich ułożył P.E. Leśniewski, Warszawa 1843 , s. 145.

${ }^{24}$ E. Tomiczek, System adresatywny współczesnego języka polskiego i niemieckiego. Socjolingwistyczne studium konfrontatywne, Wrocław 1983. 
Dzień dobry waszmość panu (szlachcic do szlachcica, II poł. XVIII w.) BohK2, 115;

Dzień dobry łaskawej pani (gospodyni do przekupki warszawskiej ${ }^{25}$, początek XIX w.) WójSp 105;

Dzień dobry jegomości (porucznik do starosty, I poł. XIX w.) SkarbSt 11;

Dzień dobry mojem paniom (panna sklepowa do modystek, lata 40. XIX w.) RusWar2, 139;

Dobry dzień, panie Hrabio (hrabia do znajomego, lata 40. XIX w.) KorzDram 264;

Dzień dobry panu Pryscjanowi (szlachcianka do szlachcica, poł. XIX w.) KraszDwa 349;

Dobry wieczór panu dobrodziejowi (mieszczanin do znajomego, poł. XIX w.) KraszDz 191;

Dzień dobry państwu dobrodziejstwu (pisarz do leśniczego i jego przyjaciół, lata 60. XIX w.) CieszP 280;

Dzień dobry pannie Annie (znajomy do mieszczki, lata 60. XIX w.) KraszSt 29.

Chociaż formy adresatywne w celowniku stosowano dość często i nie można mówić o ich zanikaniu w badanym czasie (pojawiły się nawet w poradniku), to jednak widoczna jest przewaga adresatywów wołaczowych:

Dzień dobry, braciszku (brat do brata, II poł. XVIII w.) BohK1, 378;

Dobry dzień, panie Antoni (służąca do służącego, koniec XVIII w.) CzarKom 365;

Dzień dobry, mości panowie (szlachcic do gości, II poł. XVIII w.) BohK2, 56;

Dzień dobry, mościa panno Petronelu (sługa do służącej, koniec XVIII w.) CzarKom 365;

Dzień dobry, moja Basiu (służący do chłopki, koniec XVIII w.) KniaźDram 198;

Dzień dobry moje serce (mąż do żony, początek XIX w.) NiemDom 6;

Dobry wieczór, panie bracie (rejent do marszałka, I poł. XIX w.) FrDz2, 113;

Dzień dobry Bartłomieju (służąca do sługi, lata 20. XIX w.) OlPam1, 340;

Dzień dobry przyjaciele (gospodarz do gości, lata 20. XIX w.) PawEd 76;

Dzień dobry panie Gabryelu (regent do znajomego, lata 40. XIX w.) RusWar3, 313;

Dzień dobry, panie Lucyanie (baronowa do gościa, poł. XIX w.) BujSt 77;

Dzień dobry, mospani Jędrzejowa (policjant do mieszczki, lata 60. XIX w.) KraszSt 84.

Możliwe było również połączenie formy adresatywnej celownikowej z wołaczową:

Dzień dobry wam, Helenko (góral do chłopki, II poł. XVIII w.) KniaźDram 183;

${ }_{25}$ Jak podaje autor cytowanego źródła warszawskie przekupki odmawiały sprzedaży swojego towaru, jeśli nie zwracano się do nich per pani. 
Dobry wieczór Wpanu mospanie szatny (szlachic, II poł. XVIII w.) RzewLis2, 72;

Dzień dobry ci Antosiu (szlachcic do znajomego, lata 40. XIX w.) SkarbPam 52.

W badanych tekstach poświadczone zostało także użycie francuskich odpowiedników dzień dobry/dobry wieczór:

Bonjour, mon frère (szlachcic do brata, II poł. XVIII w.) BohK1, 378;

Bon jour, madame (starościna do kasztelanowej, I poł. XIX w.) KorzKom 224;

Bon soir Monsieur (baronowa do szambelana, poł. XIX w.) BujSt 175.

Powitania te odzwierciedlają ówczesną modę na francuszczyznę wśród arystokracji.

Omówione formuły powitalne wskazują, że w sytuacji, gdy partnerzy byli sobie równi, dzień dobry/dobry wieczór pozbawione jakiejkolwiek obudowy etykietalnej było uważane za zbyt mało grzeczne. W całym zebranym materiale znajdziemy niewiele takich powitań:

Dobry wieczór (chłop wchodząc do chaty, lata 40. XIX w.) KraszU 79; (mieszczanin do znajomego, poł. XIX) KraszDz 191;

Dzień dobry (przyjaciel do przyjaciela, poł. XIX w.) ŻmPow1, 265;

Dobry dzień (mieszczanin do mieszczanina, poł. XIX w.) KraszDz 260.

W relacji asymetrycznej, kiedy nadawca posiadał wyższą rangę pragmatyczną, najwyraźniej również chętnie dodawano adresatywy, choć pojawiają się też formuły pozbawione wszelkich ozdobników:

Dobry dzień (wójt do chłopa, lata 40. XIX w.) KraszU 88;

Dobry wieczór (lekarz do chłopki, poł. XIX w.) KraszJary 16;

Dobry wieczór (mieszczanin do sprzedawczyni, poł. XIX w.) KraszDz 378.

Zazwyczaj zwroty adresatywne ograniczone były do imion:

Dobry dzień, Magdalenko (szlachcic do służącej, II poł. XVIII w.) BohK2, 111;

Dobry dzień, Kajetanie (szlachcic do lokaja, kon. XVIII w.) BłP 148;

Dobry dzień ci, Anielciu (ciotka do siostrzenicy, I poł. XIX w.) KorzKom 314;

Dzień dobry pannie Apolonii (doktor do guwernantki, poł. XIX w.) KraszDz 225;

Dobry wieczór paniczowi (sprzedawczyni do zamożnego mieszcznina, poł. XIX w.) KraszDz 378.

Obudowa etykietalna w formułach powitalnych zawierających dzień dobry/ dobry wieczór, kierowanych do osób o wyższym statusie społecznym mogła mieć postać rozbudowanej grupy imiennej:

Dzień dobry, mości panie Wilson (bona do fabrykanta II poł. XVIII w.) BDr 222; częściej jednak ogranicza się do pojedynczego zwrotu do adresata:

Dzień dobry, matko, dzień dobry (chłopka do starszej chłopki, kon. XVIII w.) KniaźDram 264;

Dzień dobry dobrodziejom (zakonnik do szlachciców, pocz. XIX w.) ChodźPam 229;

Dzień dobry, stryjaszku... dzień dobry (bratanica, poł. XIX w.) KraszDwa 136; 
Dzień dobry wam (kramarz do szlachcica, poł. XIX w.) ŁozNoc s.138;

Dobry wieczór wam (chłopka do lekarza, poł. XIX w.) KraszJary 11;

Dobry wieczór panu (pisarz do plenipotenta, poł. XIX w.) KraszH 80.

Cytowane powyżej akty etykietalne nie należą do długich i wyszukanych, co zapewne wynika z faktu, iż nadawcy pochodzili z niższych warstw społecznych. Środkami, które służą wyrażeniu szacunku dla odbiorcy, są powtórzenie formuły dzień dobry oraz użycie pronominalnej formy adresatywnej w pluralis maiestaticus, co jest typowe dla dialektów ${ }^{26}$.

Ekscerpowane teksty pokazują że choć powitania dzień dobry i dobry wieczór mogły być stosowane niezależnie od rang pragmatycznych nadawcy i odbiorcy, to najchętniej używano ich jednak w relacjach równorzędnych. W przypadku, gdy interlokutorzy byli sobie równi, formuła „odwitania” była zwykle powtórzeniem dzień dobry czy dobry wieczór ${ }^{27}$. Im większa różnica statusu między nadawcą a odbiorca, tym większe prawdopodobieństwo, że odpowiedź na powitanie będzie miała postać formuły wskazującej na podrzędność odbiorcy.

\subsubsection{W listach}

Bywa, że dzień dobry/dobry wieczór pojawia się w salutacjach, choć nie są to częste przypadki:

Dzień dobry, niech Opatrzność w czerstwem zachowuje zdrowiu tak dobrych obywatelów (1789) KośWsp 10 - w ten sposób rozpoczynał list do znajomego Tadeusz Kościuszko. Szablonowy akt etykiety został rozbudowany życzeniem o charakterze religijnym oraz komplementem.

Dzień dobry Pani mojej z ucałowaniem rączek zasyłam (1799) SzymLis 102 - pisał arystokrata do starościny. Standardowe powitanie zostało wykorzystane do stworzenia nieszablonowego salutatio, które w tym wypadku zawiera czasownik (zasyłam), wskazujący na pośredni typ kontaktu. Okolicznik z ucałowaniem raczek jest również nawiązaniem do konwersacyjnej formuły całuję rączki.

Dzień dobry Panu, bo i mnie ten dzień dobrze się zaczyna (1826) LisRS 150 - to początek listu Salomei Słowackiej do Antoniego Odyńca. Jest to kolejny przykład indywidualnego rozwinięcia formuły - autorka odwołała się do jej literalnego znaczenia. W korespondencji Słowackiej z Odyńcem często spotykamy tego rodzaju powitania zarówno w języku polskim, jak i francuskim:

Dzień dobry, Panie (1826) LisRS 64;

Bon jour, mon Prince (1826) LisRS 114;

Dnia dobrego Panu życzę (1853) LisRS 323.

${ }^{26}$ A. Grybosiowa, Przyczyny zmian w polskim systemie adresatywnym, [w:] Jezyk w mieście. Problemy kultury i poprawności, red. K. Michalewski, „Acta Universitatis Lodziensis” 1998, Folia Linguistica 37, s. 57-61.

${ }^{27}$ E. Umińska-Tytoń, Polszczyzna dziewiętnastowiecznych salonów, Łódź 2011, s. 164. 
Przyczyną wyboru takiej salutacji może być fakt, że listy te miały formę dziennika - autorka codziennie dopisywała kolejny fragment i każdorazowo witała adresata. Początek listu najwyraźniej miał też informować, o jakiej porze dnia powstawały poszczególne jego części i jak najwierniej odwoływać się do sytuacji rozmowy, skoro odnajdujemy również list, który rozpoczyna się od: Dobry wieczór Panu (1826) LisRS 101.

\subsection{3. „niech będzie pochwalony...” i przekształcenia}

\subsubsection{W rozmowach}

W dobie średniopolskiej formuła ta występowała w dwóch podstawowych postaciach: Niech będzie Bóg pochwalony i Niech będzie pochwalony Jezus Chrystus, przy czym ta druga fraza została wprowadzona dopiero w XVIII wieku listem papieża Benedykta XIII, który za jej używanie obiecywał sto dni odpustu ${ }^{28}$. Z ustaleń M. Cybulskiego wynika, że w okresie średniopolskim użycie obu formuł było rzadkie i ograniczone do duchowieństwa katolickiego ${ }^{29}$. Co ciekawe, A. Brückner pisał, że Niech będzie pochwalony Jezus Chrystus w końcu XVII w. wyrugowało starsze powitania o charakterze religijnym: Bóg pomóż, Bóg pomagaj, Pomagabóg ${ }^{30}$. W badanym okresie rzeczywiście formuły te nie występują - jedynie raz pojawia się fraza Pomagaj Bóg waszej miłości (ubogi szlachcic do zamożniejszego, pocz. XIX w.) WójSp 213.

Formuła Niech będzie Bóg pochwalony prawdopodobnie również zanikała pod koniec epoki średniopolskiej, bo w ekscerpowanych tekstach została odnotowana tylko dwa razy:

Niechaj będzie Bóg pochwalony (chłop do chłopa, lata 20. XIX w.) OlPam1, 128;

Niech Bóg będzie pochwalony (ubogi szlachcic do zamożnego, lata 20. XIX w.) OlPam1, 38.

A. Brückner ograniczał stosowanie tego powitania do spotkań z Żydami, przy czym sami Żydzi również mieli je stosować ${ }^{31}$ - wydaje się, że traktował tę formułę jako odpowiednik Niech będzie pochwalony Jezus Chrystus przeznaczony dla wyznawców judaizmu.

28 A. Komoniecki, Chronografia albo dziejopis żywiecki, wyd. S. Szczotka, t. 2, Żywiec 1939, s. 309.

${ }^{29}$ M. Cybulski, Obyczaje językowe..., s. 30-31.

${ }^{30}$ A. Brückner, Encyklopedia staropolska, t. 2, Warszawa 1939, s. 241.

${ }^{31}$ Ibidem. 
W pierwszym stuleciu epoki nowopolskiej powitanie Niech będzie pochwalony Jezus Chrystus pojawia się dość często, a jego użycie nie jest już ograniczone do środowiska katolickiego duchowieństwa. Najczęściej spotykamy je w rozmowach osób z niższych warstw społecznych: chłopów i ubogiej szlachty. Formuła ta należy do długich i dlatego chętnie ją skracano do Niech będzie pochwalony ${ }^{32}$. Mogła wystąić również w wersji łacińskiej: Laudetur Jesus Christus (zakonnik do szlachcica, przełom XVII/XIX w.) BykPam2, 88. W tej postaci stosowali ją prawdopodobnie tylko duchowni, bo chłopi i uboga szlachta łaciny nie znali.

Oto przykłady użycia tego powitania w sytuacji, gdy nadawcę i odbiorcę nie dzieliła różnica rang społecznych:

Niech będzie pochwalony Jezus Chrystus (podstoli wchodząc do karczmy pełnej szlachty, II poł. XVIII w.) ChodźPam 105; (szlachcic do regenta ${ }^{33}$ kon. XVIII w.) RzewPam 193; (mnich do mieszczki, chłopi lata 30-te XIX w.) OrWęd 59, 259; (ksiądz do szlachcica zagrodowego, lata 30. XIX w.) SkarTar 46; (uboga szlachta zaściankowa, poł. XIX w.) ŁozCh3, 14;

Niechże będzie pochwalony Jezus Chrystus (zakonnik do mieszczan, lata 60. XIX w.) KraszSt 41;

Niechże będzie pochwalony... (chłopka wchodząc do chaty sąsiadki, lata 80 . XVIII w.) KniaźDram 267.

W przypadku, gdy nadawca stał wyżej w hierarchii od swego rozmówcy, użycie akurat tej formuły w funkcji powitania było prawdopodobnie przejawem świadomości, że jest ona właściwa dla środowiska odbiorcy:

Niech będzie pochwalony Jezus Chrystus (hetman do ubogiego szlachcica, II poł. XVIII w.) WójDw 21; (baron do chłopów, I poł. XIX w.) Kpt 181; (powstaniec do chłopów, 1830) JanAu 256; (guwernantka do chłopów, poł. XIX w.);

Ojcze Idzi, niech będzie pochwalony Jezus Chrystus (książę do zakonnika, kon. XVIII w.) RzewPam 56;

Niech będzie pochwalony (hrabia do ubogiej szlachcianki, poł. XIX w.) KraszDwa 281.

Omawiana formuła była dopuszczalna również w sytuacji, gdy nadawca posiadał status niższy od statusu adresata wypowiedzi:

Niech będzie pochwalony Jezus Chrystus (lokaj do państwa ${ }^{34}$, I poł. XIX) BłP 366; (żebrak do szlachcica, lata 40. XIX w.) SkarbPam 34;

Niech będzie pochwalony (chłop do ubogiej szlachcianki, koniec XVIII w.) BolBez 43; (chłop do mieszczanina poł. XIX w.) KraszDz 183.

${ }^{32} \mathrm{~W}$ dzisiejszej polszczyźnie możemy usłyszeć tę formułę sprowadzoną do samego pochwalony. M. Marcjanik, Polska grzeczność..., s. 18-19.

${ }^{33}$ Chodzi tu o urzędnika grodzkiego, a nie o osobę, która sprawuje władzę w imieniu monarchy. Z. Góralski, Urzędy i godności w dawnej Polsce, Warszawa 1983, s. 96-97.

${ }^{34} \mathrm{~W}$ cytowanym źródle pojawia się uwaga, że był to dom szlachty przywiązanej do tradycji, w którym obowiązywała taka formuła. 
Charakterystyczną cechą tego powitania jest brak językowych wykładników wskazujących na status społeczny rozmówców. Nie ma tu w ogóle obudowy etykietalnej — tylko w jednym z cytatów pojawiła się forma adresatywna. Przyczyną był zapewne religijny charakter aktu. Formuła jest bardzo stabilna, jedyne jej modyfikacje to skrócenie lub dodanie partykuły wzmacniającej.

Ciekawy wyjątek stanowi natomiast akt, o którego pojawieniu się zadecydowały czynniki pozajęzykowe. Cytuje go w swoich Pamiętnikach Fryderyk Skarbek: Niech będzie pochwalony Jezus Chrystus, wiara i ojczyzna SkarbPam 195. Tak rozbudowanej formuły mieli używać oficerowie polscy w czasie powstania listopadowego, gdy wchodzili do obywatelskich domów. Dodanie do aktu powitalnego, mającego normalnie charakter religijny, rzeczowników wiara i ojczyzna nadawało jej wydźwięk patriotyczny, adekwatny do sytuacji zrywu narodowowyzwoleńczego. W tym przypadku wiara była prawdopodobnie nie tylko odwołaniem do religijności pozdrawianych, ale stawała się również znakiem patriotyzmu, nawiązując się do stereotypu Polaka-katolika. Dzięki wydłużeniu frazy akt powitalny nabierał podniosłego, uroczystego wydźwięku. Być może pełnił również funkcję hasła pozwalającego rozpoznać powstańców.

\subsubsection{W listach}

W ekscerpowanych tekstach formuła ta w roli powitania występuje jedynie dwukrotnie. Raz zapisana w postaci skrótu:

NBPJCH [Niech będzie pochwalony Jezus Chrystus] (1754), KKor 17 - tak rozpoczęła list do syna matka Ignacego Krasickiego;

i raz w pełnej formie:

Niech będzie pochwalony Jezus Chrystus (1849), ChopKor2, 318 - salutacja $\mathrm{z}$ listu księdza do znajomej szlachcianki.

Zbyt skromny materiał nie pozwala ocenić, czy takie powitania epistolarne ograniczone były tylko do środowiska katolickiego duchowieństwa.

\subsection{FORMUŁY POCHODZAZCE OD FRAZ ZAWIERAJĄCYCH 1. OSOBĘ TRYBU OZNAJMUJĄCEGO}

Większość omawianych tu aktów grzecznościowych to nazwy zachowań, które miały towarzyszyć powitaniu i zostały utrwalone w formułach etykietalnych. Trzeba przy tym pamiętać, że tylko część gestów, których nazwy pojawiają się w omawianych dalej aktach powitalnych, rzeczywiście była wykonywana zapewne kłaniano się sobie i całowano ręce, ale już ścielenie się do stóp czy całowanie nóg pozostawało jedynie na płaszczyźnie językowej.

Część prezentowanych poniżej formuł pełniła nie tylko funkcję powitania, ale pojawiała się także w roli pożegnań. 


\subsection{1. „padam/ścielę się do nóg/stóp” i przekształcenia}

\subsubsection{W rozmowach}

W okresie średniopolskim akty tego typu były wyłącznie formułami epistolarnymi stosowanymi w subskrypcjach. Pierwotnie takie zakończenia pojawiały się tylko w korespondencji do króla, ale z czasem zaczęto je stosować również w listach do adresatów niższego stanu. Od końca XVII w. w subskrypcjach listów do osób posiadających bardzo wysoką pozycję występowała również formuła ściskam nogi ${ }^{35}$. W pierwszym wieku doby nowopolskiej użycie tych aktów etykietalnych jest znacznie szersze. Nie jest już ograniczone do epistolografii, a ponadto formuly te pełnią funkcję nie tylko pożegnań, ale także powitań. Akty, które z założenia miały być wyrazem pokory i uniżoności, w badanym okresie uległy daleko idącej konwencjonalizacji. Świadczy o tym fakt, że w ekscerpowanych tekstach częściej pojawiają się one w relacjach równorzędnych niż w sytuacji, gdy nadawca ma niższy status od odbiorcy.

W przypadku gdy rozmówcy posiadali podobną pozycję społeczną, formuły wyglądały następująco:

Nogi ściskam waćpana dobrodzieja (szlachta, II poł. XVIII w.) CzarKom 149;

Do nóg upadam (szlachcic do podkomorzego, II poł. XVIII w.) WybDr 167;

Upadam do nóg pańskich (sługa do sługi, II poł. XVIII w.) ZabDz1, 258;

Upadam do nóg waszmość pana dobrodzieja (szlachcic do gościa, II poł. XVIII w.) BohK2, 378;

Upadam do stóp waszmość pana dobrodzieja (szlachcic do pułkownika, II poł. XVIII w.) BohK2, 48;

Upadam do nóg waszmość pana dobrodzieja (szlachta, II poł XVIII w.) BohK2, 115;

Upadam pod nogi pańskie pana i dobrodzieja (szlachta, II poł XVIII w.) KK 350;

Padam do nóg (baron do literata, I poł. XIX w.) FrDz2, 246;

Ściele się do stópek (marszałek dworu wojewodzica do kasztelanki, I poł. XIX w.) KorzKom 155;

Do nóg mię Pani ścielę (szlachta, lata 20. XIX w.) NiemPod 14;

A ścielę się pod stopki pana starościca (szlachcic, lata 30. XIX w.) SkarbDod 22;

Do nóg upadam pana dobrodzieja (sędzia na powitanie do rządcy, poł. XIX w.) ŁowDw 221;

Upadam do nóg (szlachcic do starszej szlachcianki, poł. XIX w.) KraszDwa 291.

Przedstawione akty pod względem formalnym są dość zróżnicowane. Szyk wyrazów nie jest stały — fraza może zaczynać się od przyimka lub od czasowni-

${ }^{35}$ M. Cybulski, Obyczaje językowe..., s. 74-77. 
ka. Człon werbalny ma postaci: padam, upadam, ścielę się, ściskam, a nominalny nogi, nóżki, stopy, stópki. Hipokorystyczna forma rzeczownika była stosowana nie tylko w kontaktach z kobietami, ale również w stosunku do mężczyzn, a jej funkcją nie była feminizacja, ale zwiększenie grzeczności powitania ${ }^{36}$. Innym sposobem intensyfikacji formuły były wieloskładnikowe określenia adresata. Spotykamy także akt rozbudowany o kolejną frazę: Upadam do nóżek, caluję stopki (szlachcic do dam na powitanie, II poł. XVIII w.) BohK2, 455; oraz reduplikację formuły ze zmianą szyku: Padam do nóg, do nóg upadam waszmość panny dobrodziejki (szlachcic na powitanie panny, o której rękę się starał, ok. 1770) CzarKom 98.

Powitania kierowane do osób o wyższej randze wyglądają bardzo podobnie. W pojedynczych przypadkach pojawiają się dodatkowo formy atrybutywne i okolicznik nisko:

Ściskam nogi waćpana dobrodzieja (żona lichwiarza do szlachcica, lata 70 . XVIII w.) CzarKom 172;

Trzykroć twoje ściskam nogi, gościu dawno upragniony (lichwiarz do szlachcica, II poł. XVIII w.) FrDz2, 159;

Padam do nóg (plenipotent do szlachcica, II poł. XVIII w.) WybrDr 119;

Do nóg mię ścielę (plenipotent do szlachcica, II poł. XVIII w.) WybrDr 82;

Padamy do nóg panoska Burdziła (Cyganka do szlachcica, II poł. XVIII w.) WybDr 371;

Upadam do stóp pańskich (guwerner do szlachcica, swego pracodawcy, II poł. XVIII w.) BohK1, 108;

Upadam do stóp waszmość państwa dobrodziejów (sługa do szlachciców, II poł. XVIII w.) BohK2, 233;

Padam do nóżek Wielmożnemu Panu (lichwiarz na powitanie do kapitana, I poł. XIX w.) ŁozHis, 113;

Do nóg pańskich upadam nisko (sługa do szlachcica na powitanie, I poł. XIX w.) FrDz1, 102;

Upadam do nóg Pani Szambelanowej Dobrodziki (pułkownik, I poł. XIX w.) KorzWd 38;

Ściele się do stóp pana barona (szuler karciany do barona, lata 40. XIX w.) RusWar4, 50;

Upadam do nóżek kochanego barona dobrodzieja (komornik do barona, poł. XIX w.) ŁozCh2, 84.

W analizowanych tekstach tylko raz spotykamy formułę bardziej ceremonialną, w której pojawia się czasownik honoryfikatywny: Mam honor, proszę Jegomości, upaść do nóg (szeregowiec do podporucznika, lata 40. XIX w.) KorzSt 46.

Podobna obudowa etykietalna formuł używanych w relacji symetrycznej i asymetrycznej przypuszczalnie wynika $\mathrm{z}$ faktu, że były to akty, które bardzo

${ }^{36}$ Ibidem, s. 77. 
wyraźnie wskazywały na niższą rangę nadawcy i nie były już konieczne kolejne elementy, które dodatkowo by to podkreślały. $\mathrm{Z}$ tego zapewne powodu, mimo daleko idącej konwencjonalizacji, takie powitania nie znalazły zastosowania, gdy nadawca posiadał wyższą rangę od adresata. Natomiast używanie ich w sytuacji równego statusu interlokutorów było wynikiem stosowania się do jednej z tradycyjnych polskich zasad grzecznościowych: pomniejszania własnej wartości ${ }^{37}$.

Przebadany materiał pokazuje, że zasięg społeczny omawianych aktów ograniczony był głównie do szlachty - nawet jeśli używali takich formuł słudzy, to zapewne był to wynik przebywania w tym środowisku.

\subsubsection{W listach}

W ekscerpowanej korespondencji tylko raz spotykamy salutację, która świadczy o tym, że możliwe było użycie tego rodzaju formuł także we wstępie listu:

JWM Dobrodziejce do nóg upadam; za pozwoleniem JW Pana Dobrodzieja. JMci Panu Pułkownikowi Zenowiczowi wierny respekt oddaję. Brat mój ściska nogi. - jest to początek listu Stanisława Konarskiego do Józefa Sapiehy (II poł. XVIII w.) KonL 193. Tak długie powitanie, składające się z trzech formuł werbalnych o bogatej obudowie etykietalnej wynikało zapewne $\mathrm{z}$ wysokiej rangi adresata.

\subsection{2. „kłaniam”/,kłaniam się"}

Formuła ta pełniła podwójną funkcję: mogła być zarówno powitaniem, jak i pożegnaniem. Występowała w rozmowach od początku XVIII stulecia ${ }^{38}$. Pierwotnie kłaniam nazywało gest towarzyszący powitaniu, a z czasem zaczęło znaczyć tyle co witam. Spotykamy ją w całym badanym okresie, ale zdecydowana większość odnotowanych użyć pochodzi z XVIII wieku. Najczęściej kłaniam obserwujemy w relacji symetrycznej:

Kłaniam się waszmość panu (szlachcic do szwagra II poł. XVIII w.) BDr 70;

Kłaniam, panie Marcinie (piwowar do bednarza, II poł. XVIII w.) BDr 200;

Kłaniam się jako najuniżeniej waćpannie (szlachcic do szlachcianki, II poł. XVIII w.) KK 307;

Kłaniam, panie Franciszku (pisarz miejski do mieszczanina, II poł. XVIII w.) WybDr 386;

Kłaniam jak najniżej waszmość panu (szlachta, II poł. XVIII w.) BohK1, 310;

Pannie generałównie się kłaniam (szlachcic do szlachcianki, II poł. XVIII w.) RzewLis2, 59;

\footnotetext{
${ }^{37}$ M. Marcjanik, Grzeczność..., s. 20-21.

${ }_{38}$ M. Cybulski, Obyczaje językowe..., s. 33.
} 
Kłaniam waszeci mości panie szatny (szlachcic, II poł. XVIII w.) RzewLis2, 67;

Kłaniam waszmość panu, mości panie Ucieszyński (pisarz do aktora, II poł. XVIII w.) BohK2, 413;

Kłaniam moim dobrodziejom (szlachta, II poł. XVIII w.) BohK2, 228;

Kłaniam waszmość panu (ekonom do guwernera, II poł. XVIII w.) BohK2, 192;

Uniżenie kłaniam waćpanu (panna do kawalera, lata 70. XVIII w.) CzarKom 104;

Uniżenie kłaniam mości panie Fircyk (szlachcianka do znajomego, lata 70. XVIII w.) CzarKom 98;

Kłaniam ci, panie Stanisławie (ubogi student do syna furmana, koniec XVIII w.) BoCu 69.

Jak pokazują powyższe przykłady, czasownik łączono z celownikiem lub wołaczem adresatywu. Zdarza się również, że w jednym akcie występują obydwa rodzaje zwrotu do odbiorcy. W skład obudowy etykietalnej często wchodził również przysłówek uniżenie (niekiedy w celu intensyfikacji w formie superlatywnej). O tym, że okolicznik ten miał już tylko konwencjonalny charakter, świadczy fakt, że pojawiał się zarówno w relacjach symetrycznych, jak i asymetrycznych.

Formuły, których używano, gdy nadawca posiadał wyższą rangę od partnera interakcji, były podobne do stosowanych $\mathrm{w}$ przypadku takiego samego statusu rozmówców:

Kłaniam, panie guwerner (szlachcic, II poł. XVIII w.) BohK1, 108;

Kłaniam waszmość pannie (szlachcic do służącej swojej narzeczonej II poł. XVIII w.) BohK2, 205;

Kłaniam, moja panno (burgrabia do służącej, II poł. XVIII w.) BDr 144;

Kłaniam, moja pani (szlachcic do żony lichwiarza, lata 70. XVII w.) CzarKom 172;

Kłaniam uniżenie (ojciec do córek, początek XIX w.) NiemDom 13;

Kłaniam Waszeci (starościc do plenipotenta, poł. XIX w.) KraszH 158.

Jedynym językowym wykładnikiem podrzędności odbiorcy mogą tu być poufałe formy adresatywne: panie guwerner, moja panno, moja pani czy waszec ${ }^{39}$.

Powitania zawierające kłaniam stosowane, gdy nadawca miał niższy status od odbiorcy, nie wyróżniają się na tle pozostałych użyć, sprawiają wrażenie wręcz zdawkowych:

Kłaniam pani doktorko (rozbójnik do lekarki, poł. XVIII w.) ProcPil 58;

Kłaniam waszmość panu (kupiec do szlachcica, II poł. XVIII w.) BohK2, 78;

Kłaniam jak najniżej (lokaj do szlachcica, II poł. XVIII w.) BohK2, 76;

Kłaniam się waćpanu (plenipotent do starościca, II poł. XVIII w.) WybDr 92;

Kłaniam uniżenie (pisarz miejski do burmistrza, II poł. XVIII w.) WybDr 384.

${ }^{39}$ M. Cybulski, Z historii polskich form ..., s. 459-473. 
Z ekscerpowanych tekstów wynika, że najchętniej amplifikowano kłaniam w relacjach symetrycznych - to tam znajdziemy najbardziej rozbudowane zwroty do odbiorcy, często dodatkowo pojawia się również okolicznik uniżenie. Przy nierównorzędnym statusie rozmówców nie łączono w jednej formule celownikowych i wokatywnych adresatywów, a jeśli pojawia się uniżenie, to jest jedynym elementem obudowy aktu. Zasięg społeczny ktaniam obejmuje zarówno szlachtę, jak i mieszczaństwo.

\subsection{3. „całuję rączki/stopy” i przekształcenia}

\subsubsection{W rozmowach}

Formuły te są kolejnym przykładem aktów grzecznościowych, początkowo występujących w zakończeniach listów do osób najwyżej postawionych ${ }^{40}$, które z czasem spospolitowały się i zaczęły pojawiać w funkcji powitań lub pożegnań w rozmowach. W początkach doby nowopolskiej używano ich nie tylko wtedy, gdy nadawca posiadał niższy status od partnera interakcji, ale także w relacji symetrycznej, co świadczy o konwencjonalizacji tych aktów.

W przypadku, gdy interlokutorzy posiadali podobny status społeczny, omawiane akty powitań charakteryzowała duża wariantywność:

Całujemy stopy pańskie (szlachcic do starosty, II poł. XVIII w.) BohK2, 23;

Mam honor adorować stopy waszmość panny (zubożały szlachcic do mieszczki, II poł. XVIII w.) BohK2, 33;

Całuję raczki pani starościny dobrodziki (wojewodzic, II poł. XVIII w.) KorzKom 178;

Spieszę z ucałowaniem rącząt waszmość panny dobrodziejki (kawaler do panny, lata 70. XVIII w.) CzarKom 104;

Mam honor całować raczki panienki (szeregowiec do żony lokaja, lata 40. XIX w.) KorzSt 70.

Zacytowane przykłady świadczą o tym, że obok aktów szablonowych często pojawiały się formuły dość mocno zindywidualizowane, np. całuję zostało zastąpione przez adoruje, czy przez frazę spieszę z ucałowaniem. Elementem stałym pozostawało natomiast dopełnienie: stopy lub raczki - w tym przypadku bezwyjątkowe było hipocoristicum (również w powitaniach kierowanych do mężczyzn), które zwiększało uprzejmość powitania.

Zdecydowanie większa stabilność cechowała tego typu akty powitalne, gdy osoba o niższym statusie zwracała się do osoby o wyższej randze pragmatycznej:

Catuję stopy pańskie (guwerner do szlachcica, II poł. XVIII w.) BohK1, 175;

${ }^{40}$ Pierwotna postać subskrypcji całuję ręke kierowana była w korespondencji do króla. M. Cybulski, Obyczaje językowe..., s.78. 
Całuje raczki (sługa barona do szlachcianki, I poł. XIX w.) FrDz1, 290;

Całuje raczki pańskie (komisjoner do barona, I poł. XIX w.) FrDz2, 276;

Całuję raczki Pani Jenerałowej Dobrodziki (pułkownik do generałowej, I poł. XIX w.) KorzWd 9;

Całuje raczki kochanej cioci i wujaszka dobrodzieja (szlachta, I poł. XIX w.) KorzKom 125;

Całuję stopy wielmożnego pana (sługa do asesora, lata 40. XIX w.) CieszT1, 119.

Być może sytuacja witania osoby stojącej wyżej w hierarchii społecznej sprzyjała używaniu formuł standardowych, które były gotowymi schematami $\mathrm{i}$ ich zastosowanie nie groziło popełnieniem żadnego nietaktu. W relacjach symetrycznych pozwalano sobie najwyraźniej na więcej swobody.

\subsubsection{W listach}

W korespondencji z tego okresu tylko dwukrotnie odnotowujemy formuly, które realizują omawiany wzorzec:

Serdecznie rqczki całuję (1770) LisKos s.119 - zwracała się kasztelanowa w liście do przyjaciółki;

Catuję raczki JOWXM Dobrodziejki (1764) LisKos s.61 - kasztelanowa w liście do księżnej.

\subsection{4. ,sługa"}

Powitanie to pochodzi prawdopodobnie z subskrypcji epistolarnych w rodzaju piszę się stuga, zostaje najniższym stuga ${ }^{41}$. Z czasem element werbalny zanikał a rzeczownik uległ „nominatywizacji”42 - przypadek zależny został zastapiony mianownikiem. Dla tradycyjnej polskiej grzeczności typowa była zasada umniejszania własnej wartości ${ }^{43}$, stąd dawni Polacy zwykle odgrywali rolę sługi jako nadawcy wypowiedzi, a odbiorcy przypisywali rolę pana ${ }^{44}$. Stuga pojawiał się na pierwszym miejscu w dialogu powitalnym lub jako „odwitanie”. Zgodnie z regułami etykiety, to osoba niżej postawiona (a więc ,sługa”) powinna wypowiedzieć powitanie pierwsza. Jednak w badanym okresie ten akt grzecznościowy już tak

${ }^{41}$ M. Cybulski, Obyczaje językowe..., s. 43.

${ }^{42}$ M. Cybulski, O ograniczeniu fleksji w formulach polskiej etykiety językowej, „Rozprawy Komisji Językowej Łódzkiego Towarzystwa Naukowego" 2010, R. LV, s. 57-58.

${ }^{43}$ M. Marcjanik, Grzeczność w komunikacji... s. 20-21.

${ }^{44}$ M. Cybulski, Pan i stuga. Niektóre społeczne uwarunkowania zmian w polskich obyczajach językowych. [w:] Uwarunkowania i przyczyny zmian językowych. Zbiór studiów, red. E. Wrocławska, Warszawa 1994, s. 31-39. 
dalece zatracił zdolność do określania nadawcy jako niższego, że nieraz był używany przez osobę o wyższej randze pragmatycznej ${ }^{45}$. W analizowanym materiale pojawia się też w relacjach symetrycznych:

Uniżona stuga (mieszczka do ubogiego szlachcica, II poł. XVIII w.) BohK2, 33;

Uniżona stuga imci pana Staruszkiewicza (szlachcianka do znajomego, II poł. XVIII w.) ZabDz1, 225;

Uniżona stuga waćpana (szlachta, II poł. XVIII w.) KK 307;

Uniżony sługa waćpani (mąż do żony, II poł. XVIII w.) BDr 124;

Stuga uniżony (szlachcic do szlachcianki, poł. XIX w.) KraszDwa 349.

Przykład użycia, gdy nadawca posiadał wyższą rangę:

Stuga uniżony pana komornika (baron, poł. XIX w.) ŁozCh3, 84.

Użycie przez nadawcę o niższym statusie od interlokutora:

Zawsze dobry sługa WPana, panie Józefie (zakonnik do szlachcica, II poł. XVIII w.) RzewLis1, 221;

Uniżony stuga jaśnie wielmożnego pana (komornik do hrabiego, I poł. XIX w.) KorzKom 40.

Podane przykłady pokazują, że niemal obowiązkowym elementem obudowy etykietalnej takiego powitania była forma atrybutywna uniżony, dodatkowo podkreślająca niski status nadawcy, stosowana niezależnie od faktycznych rang rozmówców. Formuła była ponadto amplifikowana za pomocą form adresatywnych w dopełniaczu, a wyjątkowo również w wołaczu.

\subsection{5. „zdrowia życzę" itp.}

W okresie średniopolskim formuła ta pojawiała się w listach po wołaczowym adresatywie i wskazywała zwykle na wyższość nadawcy ${ }^{46}$. W dobie nowopolskiej jest już prawie niespotykana. W ekscerpowanych tekstach jedyny jej ślad odnajdujemy w korespondencji Filomatów. W używanych przez nich powitaniach doszło do elipsy czasownika performatywnego, a w funkcji dopełnienia obok lub zamiast zdrowia pojawiają się także inne rzeczowniki, które często sprawiaja, że salutacja nabiera żartobliwego charakteru. Każda formuła rozpoczyna się od określenia (z imienia lub przezwiska) nadawcy i celownikowej formy adresatywnej w różnym szyku:

Adam - Braciom Filomatom zdrowia i powodzenia (Adam Mickiewicz do Filomatów, 1820) KorFil 1820;

${ }^{45}$ M. Cybulski, O staropolskich i średniopolskich zwyczajowych określeniach nadawcy wypowiedzi, Studia Historycznojęzykowe I, red. M. Kucała i Z. Krążyńska, Kraków 1994, s. 201-211.

${ }^{46}$ M. Cybulski, Obyczaje językowe..., s. 44-45. 
Onufr Tomaszowi zdrowia, miodu i dziewek (Onufry Pietrasziewicz do Tomasza Zana, 1820) KorFil 189;

Adamowi Onufr zdrowia i pomyślności (Onufry Pietrasziewicz do Adama Mickiewicza, 1821) KorFil 210;

Jeżowi Jarosz niegderania (Franciszek Malewski do Józefa Jeżowskiego, 1821) KorFil 212;

Adamowi Jarosz pamięci o nas (Franciszek Malewski do Adama Mickiewicza, 1821) KorFil 211;

Adamowi Jarosz przechadzek, bostona, śpiewów (Franciszek Malewski do Adama Mickiewicza, 1821) KorFil 201;

Onufrowi Wiślańskiemu zdrowia i powodzenia (Adam Mickiewicz do Onufrego Pietrasziewicza, 205) KorFil 1821;

Adam Jeżowi spania i powodzenia (Adam Mickiewicz do Józefa Jeżowskiego, 1821) KorFil 207;

Adamowi Jarosz pióra w rękę (Franciszek Malewski do Adama Mickiewicza, 1821) KorFil 233.

Te oryginalne formuły pełniły zapewne funkcję integrującą korespondujących, były znakiem przynależność do Towarzystwa Filomatycznego. Młodzi ludzie nie chcieli używać szablonowych aktów. Stosowane przez nich salutacje charakteryzuje $\mathrm{z}$ jednej strony pewien łatwo rozpoznawalny schemat, $\mathrm{z}$ drugiej jednak duża swoboda w wyborze dopełnienia pozwalała na zachowanie świeżości i oryginalności formul.

\subsection{PYTANIA POWITALNE}

\subsubsection{W rozmowach}

Takie powitania były charakterystyczne dla kontaktów nieoficjalnych. Mogły inicjować rozmowę lub stanowić „odwitanie”. Czasem pytanie padało po innej formule powitalnej, ale zwykle występowało samodzielnie. Pytanie powitalne realizuje jedną z podstawowych strategii grzeczności językowej - wyraża zainteresowanie partnerem i jego sprawami. Najchętniej używano go w sytuacji, gdy nadawca był wyższy lub równy rangą odbiorcy.

Jak(że) się masz/miewasz to zdecydowanie najczęściej występujące pytanie powitalne w całym badanym okresie. Niekiedy następowało po nim kolejne, bardziej szczegółowe. Potoczny charakter tego aktu sprawiał, że najczęściej pojawiał się w rozmowach osób o tym samym statusie społecznym:

Jak się masz, kochany panie Jędrzeju? (szlachta, II poł. XVIII w.) KK 171;

Jak się waszmość pan masz? (szlachcic do szlachcica, II poł. XVIII w.) BohK2, 288; 
Jak się masz Wojciechu? (sługa do sługi, II poł. XVIII w.) ZabDz1, 258;

A witam, jak się mamy, kochany sąsiedzie? (szlachcic do szlachcica, II poł. XVIII w.) WybDr 288;

Jak się wy macie, kochana matko? (ogrodnik do gospodyni, kon. XVIII w.) KniaźDram 177;

Jak się macie nasza pani Szymonowa? (chłop do chłopki, kon. XVIII w.) KniaźDram 267;

Jak się masz? Zdrowa? (lokaj do pokojówki, kon. XVIII w.) NiemPowr 9;

Jak się mas Jonku? (żona młynarza do chłopa, kon. XVIII w.) BoCu 136;

Jak się wać masz, kumie? (szlachta, kon. XVIII w.) RzewPam 42;

Jak się masz, panie Władysławie? (szlachta, pocz. XIX w.) WójSp 206;

Jak się masz poczciwcze? (młodzieniec $\mathrm{z}$ arystokracji do kuzyna, I poł. XIX w.) DzierzS 34;

Jakże się miewasz, przyszły teściu mój kochany? (szlachta, I poł. XIX w.) FrDz1, 70;

Jakże się pan masz teraz? (szlachta, lata 20. XIX w.) OlPam1, 181;

Jak się masz kochany Luboszu? (cześnikowa do szlachcica, lata 20. XIX w.) SkarbSt 56;

Jak się macie, bracia! (studenci do kolegów uwolnionych w czasie powstania listopadowego, 1830) LewPam 41; (powstańcy do kolegów, 1830) Pam Gaj 84;

Jak się macie? (uczniowie, lata 30. XIX w.) KraszPam 130;

Jak się masz, obywatelu Grodecki (aplikant sądowy do znajomego, lata 30. XIX w.) JanAu 291;

Jak się masz, pustelniku (szlachcic do przyjaciela, lata 40. XIX w.) KraszU 109;

Jak sięmasz stary Kajetanie! (asesor do znajomego, lata 40. XIX w.) CieszT1, 119;

Jak się panna Amelia ma? (szlachcic do szlachcianki, lata 40. XIX w.) DzierzD1, 163;

Jak się masz moja synogarlico? (mąż do żony, lata 40. XIX w.) RusWar4, 64;

Pan Dobrodziej! Jak się pan dobrodziej miewa? (szlachta, lata 50. XIX w.) CieszT2, 177;

Jak sie panna Barbara ma? (służba, poł. XIX w.) KraszH 281;

Jak się miewa pan podczaszyc? (podkomorzanka, poł. XIX w.) BujSt 285;

Jak się masz Edmundzie? (dziennikarze, poł. XIX w.) KuczGodz 54.

Osoby posiadające wyższą rangę również chętnie za pomocą pytań powitalnych witały rozmówców o niższej pozycji społecznej:

Jak się masz, kochana Agatko? (szlachcic do służącej, II poł. XVIII w.) BohK2, 36;

Jak się masz, moje dziecię? (ojciec do córki, II poł. XIX w.) KK 329;

Krystyniuchno! Jak się ma moja Krystynichna? (babka do wnuczki, pocz. XIX w.) DemD 150;

Jak się masz stary poczciwcze, czyś zdrów? (szlachcic do sługi, pocz. XIX w.) ChodźKon 245; 
Kostusiu, jak się masz? (proboszcz do włościanki, I poł. XIX w.) Kpt 175; Jak się pan masz? (ksiądz kanonik do więźnia, I poł. XIX w.) PamGal 132; Jak się macie chłopcy? (książę Konstanty do żołnierzy, I poł. XIX w.) PamUł 10; Jak się macie? (stały klient do obsługi kawiarni, lata 30. XIX w.) KraszPam 120;

Jak się masz Gajewski? (kapitan do porucznika, lata 30. XIX w.) PamGaj 84; Jak się masz panie Sanger? (szlachcic do lichwiarza, I poł. XIX w.) ŁozHis 69;

Jak się macie, Kajetanie? (szlachcic do sługi, lata 40. XIX w.) CieszT1, 141;

Jak się masz stary? (szlachcic do sługi, poł. XIX w.) KraszJer 96;

Jak się asindziej ma? (starościc do plenipotenta, poł. XIX w.) KraszH 158.

W ekscerpowanych tekstach odnajdujemy bardzo nieliczne przypadki, gdy pytanie powitalne jest kierowane przez osobę o niższej randze do wyżej postawionego partnera interakcji:

Jak się masz, serdeczny przyjacielu? Mam w czym służyć waszmość panu? (dłużnik do szlachcica, II poł. XVIII w.) BohK1, 190;

Jak się Pan ma Mości Pułkowniku? (żołnierz do Kilińskiego, kon. XVIII w.) PamOśm1, 226;

Jak sie masz chłopcze (maziarz do znajomego młodego szlachcica, poł. XIX w.) ŁozNoc 131;

Jak się macie ojcze (chłop na powitanie do starszego, poł. XIX w.) KraszJer 182.

Przytoczone przykłady stosowania tego aktu pokazuja, że miał on bardzo szeroki zasięg społeczny - używali go chłopi, mieszczanie i szlachta. Jedyny element obudowy etykietalnej pytania powitalnego to przede wszystkim wołaczowe, ale niekiedy też mianownikowe, formy adresatywne. Często wskazują one na bliskie, nieformalne relacje interlokutorów. Zwykle zwroty do odbiorcy kończą formułę, bardzo rzadko ją rozpoczynają, a czasami występują po zaimku zwrotnym, a przed czasownikiem.

Inne tego typu akty grzecznościowe mają dużo niższą frekwencję i przyjmują różną formę. Kilkakrotnie pojawiają się pytania o zdrowie, w których końcówka 2. osoby jest śladem czasownika być:

Czy zdrowiście tu wszyscy? (służący do chłopki, II poł. XIX w.) KniaźDram 198;

Czy zdróweś? (służąca do służącego, II poł. XVIII w.) CzarKom 365;

Czyś zdrów ojczaszku? (mieszczanin do bernardyna, lata 60. XIX w.) KraszSt 41;

Inne powtarzające się pytanie to co stychać?:

Cóż tam słychać panie Tomaszu? (chorąży do przyjaciela, lata 20. XIX w.) OlPam1, 202;

Co słychać Moszko? (wicegubernator do Żyda, lata 20. XIX w.) OlPam1, 107;

Cóż tu u jegomości słuchać? (Żyd do szlachcica, lata 40. XIX w.) DzierzDz 85; 
Mój Borowski, powiedzże mi, co tu u was słychać? (prezes do rządcy na powitanie, poł. XIX w.) KraszDwa 361;

Ale co tam u was słychać? (bernardyn do mieszczan, lata 60. XIX w.) KraszSt 42.

W dialogach powitalnych pojawiają się też pytania uwarunkowane konkretnymi okolicznościami np.:

Jak stryjaszek spał? (szlachta, II poł. XVIII w.) PamOch2, 278;

A skądże to jedziecie? (garncarz na powitanie do chłopa, poł. XIX w.) KraszJer 146;

Cóż pan baron tu robi? (szlachcic do znajomego spotkanego na spacerze, poł. XIX w.) KraszDz 44.

Odpowiedzi na pytania powitalne w badanym okresie nie dadzą się sprowadzić do żadnych schematów, dlatego nie będą w pracy omawiane.

\subsubsection{W listach}

Kilkakrotnie w analizowanej korespondencji znajdujemy listy, w których funkcję salutacji pełnią pytania powitalne:

Najpierw uściskawszy WMP serdecznie, o jego zdrowie i samej JMci się pytam (Ignacy Krasicki w liście do brata, 1760) KKor 36;

Już też, mój Adamie, czy ty żyjesz, czy nie żyjesz, czy zdrów, czy chory jesteś? (Józef Jeżowski do Adama Mickiewicza, 1820) KorFil 179;

Jak się ma pańskie zdrowie? (szlachcic do posła, 1839) TrenLis 17;

Czyście zdrowe, czy moja Bianeczka nie chora? (Narcyza Żmichowska do przyjaciółki, 1846) ŻmLis 48;

Jakże się masz? (Fryderyk Chopin do przyjaciela, 1849) ChopKor1, 300.

Powyższe pytania powitalne kierowane były do osób zaprzyjaźnionych i rodziny. Wyrażają głównie troskę o zdrowie adresata, charakteryzuje je duża wariantywność formalna.

\subsection{UWAGI KOŃCOWE}

W pierwszym wieku doby nowopolskiej obserwujemy pewne zubożenie repertuaru aktów powitalnych w stosunku do okresu średniopolskiego. W ekscerpowanych tekstach nie pojawiają się już takie formuły jak: badź pozdrowion, pozdrowienie, pomaga Bóg, Boże daj, by zdrów byt, zdarz Bóg, poddaność (przyjaźń) zalecam, zdrowia życzę, zdrowie nawiedzam ${ }^{47}$. $\mathrm{Z}$ drugiej strony zwiększa się

\footnotetext{
${ }^{47}$ Ibidem, s. 17-53.
} 
frekwencja oraz zasięg społeczny niektórych aktów: dzień dobry/dobry wieczór, niech będzie pochwalony Jezus Chrystus, stuga.

Niektóre formuły pożegnalne typu padam/ściele się nóg, całuję rączki/stopy dopiero w badanym okresie zaczynają dodatkowo pełnić funkcję powitań. Uwagę zwraca też szybka konwencjonalizacja i degradacja aktów, które początkowo przeznaczone były do witania osób o bardzo wysokiej randze, a w omawianym okresie są używane w relacjach symetrycznych, a nawet kierowane do osób niższych rangą od nadawcy.

$\mathrm{Z}$ badanego materiału wynika, że początek doby nowopolskiej nie wykształcił żadnych werbalnych formuł inicjalnych zarezerwowanych dla komunikacji listownej. Ich frekwencja w salutacjach jest bardzo niska i są to powitania konwersacyjne przeniesione na płaszczyznę sztuki epistolograficznej. Być może ich obecność jest wynikiem realizacji promowanej wówczas przez podręczniki pisania listów zasady „pisz tak jakbyś mówił”48 i koncepcji listu-rozmowy ${ }^{49}$.

${ }^{48} \mathrm{~S}$. Szymański, Wzory biletow, listow $i$ memoryałow $w$ rożnych materyach z przydatkiem uwag w powszechności o stylu listownym przypisków względem szczegulnych listów gatunkow i drobnych przestrog względem formalności w pisaniu, t. 1, Warszawa 1784, s. 11.

${ }^{49}$ O koncepcji listu-rozmowy S. Skwarczyńska, Teoria listu, Białystok 2006, s. 40-45. 


\section{POŻEGNANIA I FORMULY KOŃCOWE W LISTACH}

Pożegnanie jest drugim, obok powitania, momentem interakcji, w którym powszechnie spotykamy werbalne akty etykietalne - tworzą one rodzaj „ramy grzecznościowej” rozmowy ${ }^{1}$. Akt pożegnania pełni również funkcję fatyczną wypowiadający je rozmówca sygnalizuje chęć zakończenia kontaktu². Brak pożegnania świadczy zwykle o konflikcie między rozmówcami - jest złamaniem zasad dobrego wychowania.

$\mathrm{O}$ ile w badanym okresie werbalne formuly etykietalne w salutacjach epistolarnych były rzadkością, to bez trudu odnajdujemy je w finalnych partiach listów. W poradniku z 1822 roku autor udziela następujących wskazówek: ,jeżeli początek bywa trudny, to i koniec nie mniéy iest takim, kiedy nieznacznie do końca zbliżyć się potrzeba, i zakończyć go przez grzeczne wyrazy, albo iak mówią pospolicie, przez gładkie i zręczne naciagnienie, wyrażaiąc wysoki szacunek; głębokie uszanowanie, wielkie poważanie, zupełne poświęcenie się na usługi, a nakoniec, nayniższy i nayposłuszniejszy sługa; wyrazy które przedtém wszystkie listy kończyły i toto nazywało się szczęsliwém zakończeniem. Teraz trzeba mieć bardzo dobry wybór w takowych wyrazach, gdy daleko lepiéy iest, powiedziawszy iuż wszystko, zakończyć w wyrazach prostych i naturalnych: tak, ieżeli się używa wyrazu, uszanowanie, mówi się: iestem z uszanowaniem; ieżeli zaś bierze się wyraz szacunku, albo upoważnienia; mówi się, mam honor bydź z naywiększym szacunkiem, albo naygłębszém upoważnieniem ${ }^{3 "}$ ". Autorzy ówczesnych listowników często zachęcali do swobody i naturalności, a wyśmiewali konwencjonalne formuły pożegnalne. Już w podręczniku z 1784 roku Stanisław Szymański jako dowód ,podłego stylu” podaje przykłady spetryfikowanych formuł werbalnych: „Proszę darować nieudolności moiey... Uniżam się pod stopy...Całuię nóżki...”. Jego zdaniem są to ,pospolite i prawie już zwietrzałe wyrazy”4. Ostro krytykuje także: „Owe naostatek przy końcu listu nieskończone przepraszania za śmiałość, oświadczania aktów naygłębszey pokory, hołdu i poddaństwa"

1 J. Warchała, Pragmatyka dialogu potocznego, „Socjolingwistyka” 1991, t. 9, s. 21-45.

2 Podręczniki dobrych manier zwykle dodatkowo wskazują, który z rozmówców powinien zainicjować pożegnanie w zależności od konkretnej sytuacji komunikacyjnej.

${ }^{3}$ J. Hautepierre, Sztuka pisania listów czyli dzieło elementarne podaiace sposób dobrego układania listów, z francuzkiego na polski język przełożone przez Wojciecha Sitkiewicza, Wrocław 1822 , s. 35.

${ }^{4}$ S. Szymański, Wzory biletow, listow i memoryałow w rożnych materyach z przydatkiem uwag w powszechności o stylu listownym przypisków względem szczegulnych listów gatunkow i drobnych przestrog względem formalności w pisaniu, t. 1, Warszawa 1784, s. 18-20.

${ }^{5}$ Ibidem, s. 23. 
Fakt, że autorzy cytowanych poradników zachęcają, by stosować formuły grzecznościowe z umiarem, a wręcz odradzają używania tych szablonowych, pokazuje zmiane, jaka zaszła w pojmowaniu ich roli w listach. Wcześniej odejście od utartych wzorców językowego savoir-vivre'u prawdopodobnie zostałoby uznane za przejaw braku wiedzy, umiejętności czy towarzyskiego obycia. W drugiej połowie XVIII wieku zaczęto jednak doceniać rolę indywidualizmu i oryginalności. Stefania Skwarczyńska pisze wręcz, że: „Odtąd będzie świetnym epistolografem nie autor posłuszny regułom, nie pilny w naśladowaniu wzorów, nie w pocie czoła ćwiczący i kreślący, lecz człowiek posiadający dobry gust i umiejący go zastosować w sztuce epistolograficznej"6. Korespondencja badanego okresu pokazuje jednak, że zwykle nie silono się na oryginalność i szczególnie w zakończeniach listów chętnie stosowano konwencjonalne frazy. Nie stronili od nich nawet najwięksi poeci polskiego romantyzmu: Adam Mickiewicz, Juliusz Słowacki i Zygmunt Krasiński.

\subsection{FORMUŁY POCHODZĄCE OD FRAZ ZAWIERAJĄCYCH 2. LUB 3. OSOBĘ TRYBU ROZKAZUJĄCEGO}

\subsection{1. „bądź/bywaj zdrów/zdrowy” i podobne}

\subsubsection{W rozmowach}

O ile w epoce średniopolskiej frazy tego typu pojawiały się rzadko ${ }^{7}$, to w badanym okresie są jednym z częściej stosowanych pożegnań. Swoim zasięgiem formuła ta objęła wszystkie warstwy społeczne. Analizowany materiał pokazuje, że odpowiedzią na takie pożegnanie mogła być ta sama fraza:

- Badźże pani zdrowa.

- Badź pan zdrów, kochany panie Alfredzie! (szlachta, lata 40. XIX w.) KorzDram 257.

Nie jest to jednak regułą i prawdopodobnie wiele zależało od miejsca rozmówców w hierarchii społecznej. W sytuacji, gdy odbiorca był niższy rangą od nadawcy zwykle odpowiadał bardziej uniżoną formułą:

- Badź zdrowa!

- Najniższa sługa. (szlachcic do służącej, II poł. XVIII w.) ZabDz1, 279;

- Badź pan zdrów.

- Sługa uniżony. (baron do notariusza, I poł. XIX w.) FrDz2, 258.

Zdecydowanie najczęściej tego rodzaju aktów używano, gdy interlokutorami były osoby o podobnym statusie społecznym. W ekscerpowanych tekstach

${ }^{6}$ S. Skwarczyńska, Teoria listu, Białystok 2006, s. 78.

${ }^{7}$ M. Cybulski, Obyczaje językowe dawnych Polaków. Formuly werbalne w dobie średniopolskiej, Łódź 2003, s. 56-57. 
dominują formuły zawierające obudowę grzecznościowa, ale frazy całkowicie jej pozbawione również nie należą do rzadkości ${ }^{8}$ :

Badź zdrowa (kochanek do kochanki, lata 80. XVII w.), KniaźDram 181; (szlachcic do narzeczonej, lata 30. XIX w.) OrWęd 37;

Badź zdrów (pisarz do kolegi, lata 30. XIX w.) WójK 68, (student do przyjaciela, lata 30. XIX w.) LewPam 31;

Badźcie zdrowi (szlachcic zaściankowy do krewnych na pożegnanie, poł. XIX w.) ŁozChcz2, 25;

Bywajcie zdrowi (szlachcic do kobiet przed wyjazdem na bitwę, II poł. XVIII w.) WójDw 172, (chłop do chłopów, lata 40. XIX w.) KraszU 90, (policjant do towarzyszy w szynku, poł. XIX) ŁozNoc 145;

Bywajże zdrów (przyjaciel do przyjaciela, I poł. XIX w.) FrDz1, 482.

Inny, rzadko spotykany wariant frazy, zawierał dodatkowo dopełnienie dalsze w postaci zaimka osobowego nadawcy:

Bywaj mi zdrów (młynarzówna do furmana, kon. XVIII w.) BoCu 48;

Badźcie mi zdrowi (aplikant sądowy na pożegnanie do rodaków w Paryżu, lata 30. XIX w.) JanAu 448.

Częściej jednak takie pożegnania były amplifikowane przez wołaczowe formy adresatywne np. w postaci tytulatury standardowej lub imienia. Przy czym zwykle miejsce imienia jest na końcu frazy, a tytulatury standardowej po rozkaźniku:

Badźcie panie zdrowe (szlachcic do szlachcianek, kon. XVIII w.) BolBez1, 37;

Bywajcie waćpanowie zdrowi (Tadeusz Rejtan do szlachty, kon. XVIII w.) RzewPam 216;

Bywaj mi WPan zdrów (rotmistrz do prezydenta Krakowa podczas powstania kościuszkowskiego, 1794) PamOśm2, 35;

Badź jejmość ${ }^{9}$ zdrowa (służąca do służącej, lata 20. XIX w.) OlPam1, 343;

Badź pan zdrów (szlachta, I poł. XIX w.) KorzKom 309;

Badź zdrowa Paulino (asesor do żony, lata 40. XIX w.) CieszT1, 5;

Ty matko, badź zdrowa (syn do matki, lata 40. XIX w.) KorzDram 182;

Bądź zdrów Kostiu (maziarz na pożegnanie do znajomego, poł. XIX w.) ŁazDw 150;

Bádź zdrów Władysławie (przyjaciel do przyjaciela, poł. XIX w.) DmNa 344.

Nie brak również bardziej rozbudowanych formuł, które mają zwykle dość osobisty charakter i wskazują na bliskie relacje między partnerami interakcji:

Bywaj zdrowa, władzicielko umysłu i serca mego (podpułkownik do skarbnikowej, II poł. XVIII w.) CzarKom 164;

${ }^{8}$ E. Umińska-Tytoń, Polszczyzna dziewiętnastowiecznych salonów, Łódź 2011, s. 169.

${ }_{9}$ O użyciu form mianownikowych w funkcji adresatywnej M. Cybulski, O ograniczeniu fleksji w formułach polskiej etykiety językowej, „Rozprawy Komisji Językowej Łódzkiego Towarzystwa Naukowego" 2010, t. LV, s. 52. 
Bywaj zdrowa, królowo moja (szlachcic do ukochanej, II poł. XVIII w.) CzarKom 365;

Bywajże zdrów, kochany panie Leonie (krajczy do szlachcica, kon. XVIII w.) RzewPam 148;

Bąź zdrów kochany Władysławie (szlachcianka do ukochanego, lata 30. XIX w.) OrWęd 37;

Bąd́ zdrowa pani, badź zdrowa piękne zjawisko mojego życia (szlachcic do ukochanej, lata 40. XIX w.) OsP1, 124;

Mój kochany panie Marcinie, bywaj mi zdrów (znajomy do znajomego, poł. XIX w.) CieszT2, 20.

Formuła mogła też być rozbudowywana o kolejne życzenia:

Bądź zdrów Stanisławie, badź spokojny (szlachcic do kuzyna, pocz. XIX w.) WójSp 113;

Badź pani zdrowa i szczęśliwa (baron do hrabianki, I poł. XIX w.) KorzKom 80;

Bywaj mi zdrów i szczęśliwy drogi kolego. Oby Ci dał Bóg wyhodować najliczniejszy zastęp dzielnych obywateli naszej ojczyźnie. (mieszczanin do przyjaciela, którego nie widział długie lata - stąd pewnie podniosły charakter formuły, I poł. XIX w.) GirtOp1, 313;

Bywajcie zdrowi, panowie gromada, miejcie się dobrze ${ }^{10}$ (maziarz do towarzyszy w szynku, poł. XIX w.) ŁozDw 20;

Badźcie zdrowi, szczęścia życzę, bardzo życzę (kapelan do huzarów, I poł. XIX w.) FrDz1, 309.

Przykłady użycia omawianego pożegnania w przypadku relacji asymetrycznych, gdy nadawca jest wyższy rangą od odbiorcy, są również liczne. Formuły te mogą być pozbawione wszelkich ozdobników:

Bąźcie zdrowi (księżna do wojska, II poł. XVIII w.) PamRadz 203;

Bąź zdrów (książę do intendenta, I poł. XIX w.) FrDz1, 56;

Śpij zdrów (szlachcic do klarnecisty, I poł. XIX w.) FrDz2, 135;

Badź zdrów (prezydent miasta do aplikanta sądowego, lata 30. XIX w.) Jan$\mathrm{Au} 238$;

Bąźcie zdrowi, niech wam Bóg szczęści (dziedzic do chłopa, poł. XIX w.) DmNa 117.

Podobnie jednak jak w przypadku aktów używanych przy równych rangach pragmatycznych rozmówców, większość omawianych fraz posiada obudowę etykietalna, szczególnie w postaci adresatywów. Czasem sposób zwracania się do rozmówcy świadczy o jego niższym statusie społecznym:

Bqqd́z zdrów, dobry sługo (hrabia do sługi, I poł. XIX w.) KorzDram 150;

${ }^{10}$ W okresie średniopolskim „miej się dobrze” było samodzielną formułą pożegnalną o wyraźnie plebejskim charakterze. W dobie nowopolskiej akt ten zanika - cytowany fragment, to jedyny poświadczony w badanych tekstach przykład jego użycia. M. Cybulski, Obyczaje językowe..., s. 57. 
Bądźzdrów poczciwy stary (szlachcic do chłopa, lata 30. XIX w.) OrWęd 193; Badźcie zdrowi, dobrzy ludzie, badźcie zdrowi (rejent do majstrów, I poł. XIX w.) FrDz2, 71;

Bywaj mi wasan ${ }^{11}$ zdrów (kapitan do ułana na pożegnanie, I poł. XIX w.) PamUł 42;

Bądź asan zdrów (hrabia do komornika, I poł. XIX w.) KorzKom 46.

Zwykle jednak formy adresatywne mają neutralny charakter:

Badź waszmość pan zdrów! (szlachcic do kupca, II poł. XVIII w.) BohK2, 84;

Bywaj zdrów $i$ wesół miły arendarzu (szlachcic do Żyda, II poł. XVIII w.) RzewLis 101;

Bądź zdrów, pułkowniku Błędowski (generał do pułkownika, I poł. XIX w.) BłP 401;

Bywaj zdrów, Geldhabie (książę do szlachcica, I poł. XIX w.) FrDz1, 112;

Bywaj pan zdrów (generał do urzędnika, poł. XIX w.) KraszSt 138.

W szczególnych okolicznościach adresatywy mogły pozytywnie wartościować odbiorcę. Stanisław August Poniatowski żegnając się z wojskiem miał powiedzieć:

Badźcie zdrowi mężni wojownicy PamRadz 117.

Przykłady użycia tego typu aktów w sytuacji, gdy nadawca był niższy rangą od odbiorcy, są jedynie sporadyczne, co zapewne świadczy o tym, że były uznawane za poufałe:

Bąźzdrów, panie majster (czeladnik, II poł. XVIII w.) BDr 186;

Zostańcie zdrowi (pasterz do oficerów, kon. XVIII w.) GodGr 29;

Bądź zdrów (chłopka do szlachcica, pocz. XIX w.) ZamT 98;

Bywajcie tedy zdrowi, Jeremiaszu (kramarz do szlachcica, poł. XIX) ŁozNoc 140.

Bezpośredniość takiego pożegnania mogło złagodzić dodanie innego aktu, wskazującego na niższość nadawcy:

Bywaj WPan zdrów! Upadam do nóg (rzeźnik do prezydenta Krakowa, kon. XVIII w.) PamOśm2, 33.

Jedynie raz w badanych tekstach pojawia się łaciński odpowiednik bądź zdrów: vale - w ten sposób zwraca się zakonnik do zakonnika (II poł. XVIII w. ChodźPam 73). Na tej podstawie trudno oczywiście stwierdzić, czy zasięg użycia vale ograniczony był do środowisk kościelnych.

${ }^{11}$ Formy adresatywne wasan i asan, to skrócenia formy waszmość pan, które szybko uległy deprecjacji. W badanym okresie zwykle sygnalizowały niższość odbiorcy wypowiedzi. H. Safarewiczowa, Tytuly grzecznościowe w „Panu Tadeuszu”, [w:] W stużbie nauce i szkole. Księga pamiatkowa poświęcona prof. doktorowi Z. Klemensiewiczowi, Warszawa 1970, s. 267-275. także M. Chmielowiec, Z życia wyrazów. Aśćka i inne tytuły staropolskie (Przykład lekcji w klasie V gimnazjalnej), „Język Polski” 1924, nr 9, s. 19. 


\subsubsection{W listach}

W epistolarnych pożegnaniach frekwencja omawianych tu aktów jest wysoka. Jednak inaczej niż w przypadku formuł konwersacyjnych, ich użycie ogranicza się praktycznie do relacji symetrycznych. Nadawca listu jest zwykle bliskim znajomym, przyjacielem lub krewnym adresata. Wynika to zapewne z faktu, że w przypadku korespondencji bardziej niż podczas rozmów dbano o przestrzeganie zasad etykiety językowej i najwyraźniej ostrożniej stosowano poufałe zwroty. Obudowa grzecznościowa formuł często podkreśla bliskie relacje między piszącymi: pojawiają się hipocoristica imion w adresatywach oraz formy atrybutywne wskazujące na zażyłość typu drogi, kochany. Chętnie dodawano też kolejne życzenia czy prośby:

Sam bywaj zdrów i zawsze mnie kochaj (Ignacy Krasicki do brata, 1763) KKor 72;

Badź mi JW Pani Dobrodziejka zdrowa (kasztelanowa do znajomej, 1772) LisKos 151;

Badź zdrowa, matko ukochana! (syn do matki, II poł. XVIII w.) WirMal 16;

Bywaj mi WMP zdrów i wesół, a szanuj się (Ignacy Krasicki do brata, 1782) KKor2, 94;

Bywaj zdrowa, kochana Anielo! (arystokratka do przyjaciółki, 1790) TańDzien 157;

Badźcie Państwo zdrowi (Hugo Kołłątaj w liście do miecznika, 1792) KołLis1, 13;

Badź zdrów i stale łaskaw (Stanisław Trembecki do pułkownika, 1802) TremNie 240; 28 ;

Bywaj więc zdrów! (Jan Czeczot do Adama Mickiewicza, 1819) KorFil

Bqdź zdrów i dobry! (Józef Jeżowski do Adama Mickiewicza, 1820) KorFil 186;

Badź zdrów i miej nas w przyjaznej pamięci (Teofil Januszewski do przyjaciela, 1829) LisRS 381;

Bqdź zdrów i o mnie spokojny (Adam Mickiewicz do Antoniego Odyńca, 1830) KorMic 49;

Badź zdrów i mnie kochaj (Fryderyk Chopin do przyjaciela, 1833) ChopKor 226;

Bqdźcie zdrowi, najukochańsi, najlepsi, najmilsi (Juliusz Słowacki do rodziny, 1834) KorSł 215;

Bądź zdrowa i szczęśliwa kochana mamo moja (Juliusz Słowacki do matki, 1834) KorSł 209;

Bąd́z zdrów, i spokojniejszy i szczęśliwszy ode mnie (Zygmunt Krasiński do przyjaciela, 1838) KraJar 14

Bąź zdrowa Kornelciu (Wincenty Pol do żony, 1841) LisPol 78; 
Bądź zawsze zdrów i wesół (Stanisław Trentowski do znajomego, 1841) TrenLis 55;

Bądź mi jaknajzdrowszy (sic!) duchem i ciałem (Seweryn Goszczyński do przyjaciela, 1844) GoszLis 180;

Badźcie zdrowi i szczęśliwi (oficjalista Potockich do przyjaciela, 1846) ChrzPam 206;

Zdrów bywaj, druchu (sic!) kochany (Teofil Lenartowicz do przyjaciela, 1851) LisLen 25;

Bywaj zdrów i kochaj Twojego najprzywiązańszego Teofila (Teofil Lenartowicz do Józefa Kraszewskiego, 1859) LenarKor 61.

W przypadku korespondencji z rodziną i z bliskimi przyjaciółmi bądź zdrów często stanowi jedynie wstęp do dalszych formuł, przez co subskrypcja nabiera bardziej osobistego charakteru, jest wyrazem ciepłych uczuć nadawcy do adresata. Swobodnie łączono różne standardowe akty pożegnań - zebrany materiał prezentuje bardzo dużą wariantywność:

Bywaj zdrowa! Ściskam Ciebie z najczulszem sercem (Tadeusz Kościuszko do siostry, 1792) KośWsp 36;

Bywajcie, ile życzę, zdrowi. Ściskam Was, jak kocham serdecznie. (Ignacy Potocki w zakończeniu listu do brata, 1801) KorPot 225;

Badź zdrów! Niech cię Bóg błogosławi. Życzę ci wszystkiego dobra, kochająca matka (Barbara Mickiewicz w liście do syna, 1820) KorFil 151;

Badźcie zdrowi, ściskam was wszystkich (Adam Mickiewicz do przyjaciół, 1826) KorMic 11;

Bądź zdrów. Niech cię Bóg pokrzepia, i rozum utrzymuje, a nadzieja zasila (Adam Mickiewicz w liście do przyjaciela, 1826) KorMic 13;

Tymczasem baqdź zdrów i przyjmij uściśnienie od twego Seweryna (Seweryn Goszczyński do przyjaciela, 1830) GoszLis 12;

Bądź zdrów, mój drogi Fryciu, całuję Cię po milion razy (siostra do Fryderyka Chopina, 1831) ChopKor1, 186;

Badźcie zdrowi. Wszystkich was całuję i ściskam. Kochana mamo, całuję ciebie serdecznie (Juliusz Słowacki do matki, 1831) KorSł 43;

Badź zdrów i kochaj mnie jak ja Ciebie. Ja zawsze jestem i będę Twoim prawdziwym i życzliwym przyjacielem (Józef Elsner do Fryderyka Chopina, 1834) ChopKor1, 247;

Bądź zdrów, Eraziu, żegnam cię, do widzenia (Narcyza Żmichowska w liście do brata, 1838) ŻmLis1, 76;

Bywaj mi zdrowy, mój drogi Edmundzie i zapewniony o moim rzetelnym szacunku i przyjaźni (Wincenty Pol do przyjaciela, 1839) LisPol 38;

Badź mi zdrowa, kochana moja, żegnam Cię (Narcyza Żmichowska w liście do przyjaciółki, 1859) ŻmLi2, 152. 


\subsection{2. „dobranoc” i przekształcenia}

\subsubsection{W rozmowach}

Znana i powszechnie dziś używana forma dobranoc ${ }^{12}$ ma taką samą genezę jak dzień dobry - wywodzi się z frazy Boże daj dobra noc. Najpierw została skrócona do postaci dobra noc, a dopiero później biernik został zastąpiony mianownikiem ${ }^{13}$. Analizowane teksty pokazują że pożegnanie to miało neutralny charakter, nie było żadnych ograniczeń w stosowaniu go - nie wskazywało na rangę rozmówców. Często forma ta występowała bez żadnych dodatkowych wykładników grzeczności:

Dobranoc (czeladnik do piwowara, II poł. XVIII w.) BDr 197; (mąż do żony, I poł. XIX w.) ŁozHis 38; (arystokrata do żony garncarza, lata 40. XIX w.) KraszU 60; (matka do córki, lata 40. XIX w.) OsP2, 39; (spiskowiec do rannego, 1861) KraszSt 94; (prezes do bratowej, poł. XIX w.) KraszDwa 187; (pisarz do plenipotenta, poł. XIX w.) KraszH 42.

Ewentualne elementy obudowy etykietalnej to przede wszystkim formy adresatywne w wołaczu lub w celowniku oraz nieliczne przymiotniki ${ }^{14}$ :

Dobranoc, tatulu (dzieci do fabrykanta, II poł. XVIII w.) BDr 273;

Dobranoc wam, zaufani moi przyjaciele (hetmanowa do szlachty, kon. XVIII w.) PamGąs 48;

Dobranoc paniom (uboga szlachta, kon. XVIII w.) BolBez1, 33;

Dobranoc, mościa pani eks-królowa (szlachcic do arystokratki, kon. XVIII w.) KarpHis 142;

Dobranoc ci, panie Hrabio (szlachcic do hrabiego, lata 40. XIX w.) KorzDram 238;

Dobranoc kumo (chłopi, poł. XIX w.) KraszJer 66;

Dobranoc ci, Gracchusie (szlachcic do szlachcica, poł. XIX w.) ŁozDw 167;

Dobranoc ci moja mamciu (mąż do żony, lata 60. XIX w.) CieszPs 54.

Zwykle na dobranoc odpowiadano tą samą formą:

- Dobranoc bat'ku! Dobranoc.

- Dobranoc wam synku. (flisak do Poleszuka, poł. XIX w.) KraszJer 35.

Możliwe jednak było też użycie innego pożegnania:

- Dobranoc! Do zobaczenia!

- Do widzenia! Do zobaczenia! (szlachcic na zakończenie wizyty w domu przyjaciół, poł. XIX) WilkWsp 224.

${ }^{12}$ H. Zgółkowa, ,Dobranoc” jako formuła grzecznościowa i nazwa własna, „Studia Polonistyczne" 1979, t. VI, s. 213-216.

${ }^{13}$ M. Cybulski, Obyczaje jezzykowe..., s. 62.

${ }^{14} \mathrm{~W}$ przypadku dzieł literackich trudno jest ocenić na ile stosowane w prezentowanych formułach grzecznościowych formy adresatywne naprawdę były stosowane w ówczesnym języku mówionym, a na ile ich rolą jest wskazywanie bohaterów. 
Dwa razy występuje inny wariant formuły, który posiada człon werbalny w postaci czasownika performatywnego życzę:

Dobrej nocy życzę Wpanu panie Michale (szlachcic do szlachcica, II poł. XVIII w.) RzewLis2, 42;

Dobrej nocy życzę panu (baronowa do znajomego, lata 40. XIX w.) RusWar4, 29.

W ekscerpowanych tekstach nie ma natomiast skrócenia tej formuly do postaci dobrej nocy, która pojawiła się na początku XVIII wieku ${ }^{15}$.

\subsubsection{W listach}

Użycie dobranoc w zakończeniach listów jest bardzo rzadkie. Być może wybór pożegnania, które wskazuje na porę dnia, podyktowany był wspomnianą już koncepcją listu-rozmowy. Zakładała ona bezpośrednią relację nadawcy i adresata, a pomijała pisemną formę listu oraz wynikające $\mathrm{z}$ tego konsekwencje. Autorki (bo w badanych tekstach są to wyłącznie kobiety) listów zakończonych dobranoc mogły podkreślać w ten sposób, że wchodzą w konwencję rozmowy - traktują zapisywane słowa tak, jakby miały dotrzeć do adresata w tej samej chwili, gdy powstaja - jak ma to miejsce w przypadku konwersacji. Świadoma konwencjonalności takich pożegnań była zapewne Narcyza Żmichowska, gdy pisała do brata:

Dobranoc teraz, a dzień dobry, gdy będziesz czytać (1838) ŻmLis1, 88.

Za pomocą prostego dobranoc (1827, LisRS 180) kończyła swoje listy do Antoniego Odyńca także Salomea Słowacka (tu dodatkową rolę odgrywał zapewne fakt, że listy te miały formę dziennika). Dobranoc ci kończy również swój list szlachcianka do przyjaciółki (1840, HoffKryst 205).

\subsection{3. „idź/jedź/bądź z Bogiem” i przekształcenia}

Użycie tych aktów pożegnalnych w początkach doby nowopolskiej jest poświadczone niewielkim materiałem. Formułę wypowiadał zwykle gospodarz do gościa, więc w dialogu kończącym spotkanie zajmowała drugie miejsce, bo zasady savoir-vivre'u nie pozwalają gospodarzowi zaczynać pożegnania. Choć sama fraza nie zawiera żadnych wykładników społecznego statusu rozmówców, to jednak szybko uległa deprecjacji ${ }^{16}$ i przykłady jej stosowania możemy odnaleźć głównie w niższych warstwach społecznych:

Jedź z Bogiem (zakonnik do ubogiego szlachcica, II poł. XVIII w.) ChodźPam 61;

Idź z Bogiem (chłop do mieszczanina, poł. XIX w.) KraszDz 189;

${ }_{15}$ M. Cybulski, Obyczaje językowe..., s. 64.

${ }^{16}$ Ibidem, s. 58. 
Idź z Bogiem dziecko, już cię pewno na ziemi nie ujrzę, ale gdziekolwiek będziesz pamiętaj o Bogu a dobrze ci będzie (matka do syna idącego na wojnę, pocz. XIX w.) BielBon2, 8;

Badź zawsze z Bogiem (ojciec do córki, I poł. XIX w.) KorzDram 41;

Idźcie dzieci moje, w imię Boga (pleban do gości, lata 20. XIX w.) PawEd 25 ;

Idźcie no z Bogiem, idźcie (chłop do mieszczanina, poł. XIX w.) KraszDz 185. Możliwe było również odrzucenie członu werbalnego:

Z Bogiem! (ksiądz na pożegnanie do spiskowca, 1861) KraszSt 123.

\subsection{4. „niech Bóg prowadzi” itp.}

Tego rodzaju frazy o genezie religijnej z analityczną formą rozkaźnika są stosunkowo nowe - powstały prawdopodobnie dopiero na gruncie nowopolskim ${ }^{17}$. Na podstawie badanego materiału można stwierdzić, że raczej nie używano ich na co dzień, a jedynie w sytuacjach, gdy rozstawano się na dłużej:

To niechże Bóg szczęśliwie prowadzi (szlachcianka do kwestarza, II poł. XVIII w.) ChodźPam 162;

Niechże ci Bóg dopomaga według twojej poczciwości, a ja życzę abyś miał los jak najlepszy (szlachcianka do sługi, pocz. XIX w.) PamFel1, 222;

Jedź tedy, drogie dziecko moje i niechaj cię Bóg błogosławi (hrabina do syna, I poł. XIX w.) ŁozHis 46;

Idź w świat o swej sile...niech cię anioł święty prowadzi w imię Ojca i Syna i Ducha Świętego Amen (matka do syna, poł. XIX w.) KraszDwa 288;

Niech Bóg prowadzi (służba do państwa, poł. XIX w.) KuKas 251.

Podniosły i religijny charakter takich aktów sprawiał, że szczególnie chętnie żegnano nimi wyruszających na wojnę:

Niechajże Bóg wszechmogący pana szczęśliwie prowadzi (zarządca majątku do właściciela na wieść o tym, że zamierza zaciągnąć się do wojsk napoleońskich, kon. XVIII w.) BielBon1, 149;

Niech cię Bóg nie opuszcza i ciagle ma w swojej świętej opiece (siostra do brata wyruszającego na wojnę, I poł. XIX w.) SkarPow 55;

Niechaj Matka Boska pana prowadzi i przy życiu zachowa (panna do szlachcica wyruszającego na powstanie, 1861) CieszP 285.

Zebrany materiał pokazuje, że akty te charakteryzuje bardzo duża wariantywność zarówno członu werbalnego: prowadzi, dopomaga, błogosławi, nie opuszcza, jak nominalnego: Bóg, anioł, Matka Boska.

${ }^{17}$ M. Cybulski nie odnotował ich obecności w tekstach średniopolskich. 


\subsection{5. ,̇̇̇egnaj/adieu"}

\subsubsection{W rozmowach}

Pożegnanie, które dziś kojarzymy głównie z sytuacjami konfliktowymi i zrywaniem stosunków ${ }^{18}$ wywodzi się prawdopodobnie ze starej formuły Bóg żegnaj ${ }^{19}$. W początkach doby nowopolskiej jest bardzo rzadko spotykane i nie presuponuje, że zakończenie kontaktu jest ostateczne:

Żegnaj, pani Agato, moje serce (służący do służącej, II poł. XVIII w.) BohK2, 32;

No, żegnaj, mój Ludwiku (przyjaciel do przyjaciela, poł. XIX w.) ŻmPow1, 436.

Zdecydowanie częściej w całym badanym okresie pojawia się adieu - francuski odpowiednik polskiego żegnaj, co wiąże się z ówczesną modą na ten język. Zasięg społeczny adieu ograniczał się głównie do arystokracji i szlachty oraz ewentualnie służby, która przejmowała ten zwyczaj językowy od swoich chlebodawców. Adieu, tak samo jak żegnaj, łączono z wołaczowymi adresatywami (niekiedy także z adresatywami francuskimi). Czasem dodatkowo pojawiała się polska formuła pożegnalna:

Adieu, przyjacielu (szlachta, II poł. XVIII w.) CzarKom 116;

Adieu, bywaj mi zdrów (szlachcianka do brata, II poł. XVIII w.) CzarKom 354;

Adieu, mościa panno (służąca do swojej pani, II poł. XVIII w.) WybDr 228;

Adieu, messieurs, dziękujemy za kawę i kompanię (szlachcic do kolegów, II poł. XVIII w.) BohK1, 470;

Adyje, siostro (szlachta, lata 80. XVIII w.) ZabF 87;

Adieu, mademoiselle (szlachcic do szlachcianki, lata 20. XIX w.) SkarbSt 70; Adieu! (książę do aplikanta sądowego, lata 20. XIX w.) JanAu 126;

Bywaj zdrów, adieu (porucznik do szeregowca, lata 40. XIX w.) KorzSt 26.

\subsubsection{W listach}

Podobnie jak w formułach konwersacyjnych, również w korespondencji żegnaj jest wypierane przez francuskie adieu. Zarówno w polskiej, jak i w francuskiej wersji formuły obudowa etykietalna to przede wszystkim formy adresatywne $\mathrm{i}$ atrybutywne:

Żegnaj, przyjacielu (porucznik do wiceprezydenta Warszawy, 1808) BielBon1, 283;

Żegnaj mój drogi przyjacielu (kapitan do przyjaciela, 1812) BielBon2, 123;

${ }^{18}$ To samo dotyczy formuły żegnam. M. Marcjanik, Polska grzeczność językowa, Kielce 2000, s. 249.

${ }_{19}$ M. Cybulski, Obyczaje językowe..., s. 61. 
Na dziś żegnajcie (Fryderyk Chopin do rodziny, 1830) ChopKor1, 152;

Żegnaj, moja serdeczna (Narcyza Żmichowska do przyjaciółki, 1861) ŻmLis 178 .

Zapewne krótkość formy adieu skłaniała czasem piszących do wzmacniania jej funkcji przez powtarzanie pożegnania lub dodawanie kolejnych formuł werbalnych:

Adieu, Kochany Dziaduniu (Ignacy Krasicki do przyjaciela, 1765) KKor 101;

Adieu, kochanku, ściskam cię serdecznie i całuję, oraz nóżki i rączki (żona do Karola Radziwiłła, 1767) KorRadz 91;

Adieu, mój Biskupie, wyglądam niecierpliwie dnia tego, gdzie WPana tu znowu osobiście przywitam i ścisnę (Stanisław August Poniatowski do Adama Naruszewicza, 1776) KorNar 59;

Adieu, kochany Gintowcie (Ignacy Potocki do sekretarza KEN-u, 1776) KorPot 20; 416;

Adieu, Mój Książę na dzisiaj (Stanisław August Poniatowski, 1780) KKor1,

Adieu, Wacławie (Seweryn Goszczyńskie do przyjaciela, 1824) GoszLis 5;

Adieu, adieu (Salomea Słowacka do Antoniego Odyńca, 1826) LiRS 171;

Adieu, mon Prince (Salomea Słowacka do Antoniego Odyńca, 1827) LiRS 245;

Adieu, kochana mamo, adieu (Juliusz Słowacki do matki 1830) KorSł 11;

Ucałuj ode mnie familię całą, każdego w szczególności najserdeczniej adieu (szlachcic do brata, 1831) PamL 41;

Adieu, matko najdroższa, do zobaczenia się (Juliusz Słowacki do matki, 1832) KorSł 112;

Adieu, adieu i tysiąc razy adieu (lekarz do przyjaciół, 1842) MorLis 71.

\subsection{6. „niech będzie pochwalony Jezus Chrystus”}

Formuła ta w funkcji pożegnania jest w ekscerpowanych tekstach rzadkością. Dwukrotnie pojawia się na zakończenie rozmowy:

Dobrej nocy życzę Wpanu panie Michale, niech będzie pochwalony Jezus Chrystus (szlachcic do szlachcica, II poł. XVIII w.) RzewLis2, 42;

Niech będzie pochwalony Jezus Chrystus (plenipotent na pożegnanie do szlachcianki, poł. XIX w.) KraszH 254.

Jedynie raz odnajdujemy ją w listownej subskrypcji:

Niech będzie pochwalony Jezus Chrystus (lekarz do przyjaciółki, 1840) MorLis 48.

Być może takie pożegnania były przejawem indywidualnej pobożności. 


\subsection{7. „przyjmij/racz przyjąć/proszę przyjąc”}

Takie dość ceremonialne zakończenia, mające na celu podkreślenie szacunku do adresata, pojawiają się prawie wyłącznie w dziewiętnastowiecznych listach osób pochodzących z wyższych warstw społecznych.

Człon werbalny ma trzy postaci: zwykłego rozkaźnika przyjmij, honoryfikatywnej frazy racz przyjać lub formuły z czasownikiem performatywnym proszę przyjąć. Człon dopełnieniowy charakteryzuje duża swoboda.

1. ,przyjmij”:

Przyjmij W.Ks.M. oświadczenie najszczerszego i najgłębszego respektu od dozgonnego swojego sługi (Stanisław Trembecki do księcia, 1801) TremNie 223;

Przyjmij pan wyraz głębokiego szacunku z jakim zostaję WMPana Dobrodzieja najniższy sługa (Adam Mickiewicz do przyjaciela, 1829) MicKor 31;

Przyjmij wyraz głębokiego szacunku i prawdziwej przyjaźni, z którą pozostaję uniżonym sługą (Stanisław Trentowski do znajomego, 1841) TrenLis 49;

Przyjmijcie zapewnienie, Drogi Panie Józefie, o najgłębszej cześci i najprawdziwszej braterskiej miłości, z jaką na zawsze pozostaję (Teofil Lenartowicz do Józefa Kraszewskiego, 1858) LenarKor 50.

2. „racz przyjąć”:

Racz generale przyjąć wyrazy wysokiego szacunku (generał do kolegi, 1812) PamWoj 226;

Racz przyjąć, Jaśnie Oświecony Mości Książę, łaskawie oświadczenie najgłębszego uszanowania i podległości, z którą mam honor być Jaśnie Oświeconej Waszej Książęcej Mości najpokorniejszym sługą (August Bécu do księcia Adama Czartoryskiego, 1818) LisRS 32;

Racz Pan Dobrodziej przyjąć wyrazy czci i uwielbienia, z jakim mam zaszczyt być na zawsze (Wincenty Pol do znajomego, 1844) LisPol 119;

Racz WPan Dobrodziej przyjać wyrażenie powinnego uszanowania z jakim zostaję WPana Dobrodzieja prawdziwym sługą (Tytus Chałubiński do wydawcy, 1848) ChałLis 35.

3. „proszę przyjąć”:

Prosze przyjąc oświadczenie, że radbym go osobiście przeświadczyć, iż z wysokim szacunkiem być nie przestanę jw pana najniższym sługą (Stanisław Szczęsny Potocki do Tadeusza Kościuszki, 1792) BukPam 95-96;

Prosze przyjać oświadczenie mego szacunku (hrabia Wincenty Krasiński do Jana Kilińskiego, 1811) PamOśm1, XIV;

Proszę przyjąć wyrazy prawdziwego szacunku i wysokiego poważania z jakim zostaję (Wincenty Pol do ziemianina, 1837) LisPol 27;

Prosze przyjać wyrazy rzetelnego szacunku (Marcelina Czartoryska do szwagra Fryderyka Chopina, 1849) ChopKor2, 318;

Cześć najwyższa, przychylność najżyczliwszą prosze przyjąć od Władysława Syrokomli (poeta do Pauliny Wilkońskiej, poł. XIX w.) WilkWsp 274. 
W prezentowanych subskrypcjach obserwujemy częste współwystępowanie omawianych formuł $\mathrm{z}$ popularną $\mathrm{w}$ epistolografii całego badanego okresu frazą werbalną: zostaję/jestem $z$ + narzędnik rzeczownika abstrakcyjnego. Połączenie tych aktów powodowało wydłużenie zakończenia i zwiększało jego uprzejmość. Ten rodzaj subskrypcji wyróżnia także bogata obudowa etykietalna, którą tworzą przede wszystkim bardzo liczne przymiotniki, często dodatkowo intensyfikowane przez wprowadzanie form superlatywnych.

\subsection{FORMUŁY POCHODZĄCE OD FRAZ ZAWIERAJĄCYCH 1. OSOBĘ TRYBU OZNAJMUJĄCEGO}

\subsection{1. „żegnam (się)"}

\subsubsection{W rozmowach}

Pożegnanie to jest znane w polszczyźnie już od drugiej połowy XVI wieku. Nie jest jednak do końca jasna jego geneza. Można by je wywodzić od formuły Boże żegnaj - tak jak witam od witaj, ale M. Cybulski za bardziej prawdopodobny uznał związek z gestem znaczenia krzyża wykonywanym i nazywanym przez nadawcę. W tym drugim wypadku za pierwotną należy uznać formę trybu oznajmującego.

W epoce średniopolskiej żegnam miało charakter ceremonialny i często wchodziło w skład dłuższej oracji ${ }^{20}$. W początkach doby nowopolskiej mocno już straciło na swej odświętności. Akt ten co prawda nadal był używany w sytuacjach podniosłych (szczególnie, gdy rozstawano się na dłużej, czy wręcz na zawsze), ale i w całkiem zwyczajnych ${ }^{21}$ :

A teraz żegnam cię, bo jadę i wrócę aż wieczór zapewne (kapitan do siostrzeńca, I poł. XIX w.) ŁozHis 145.

W zebranym materiale możemy też zaobserwować wykształcanie się nowej funkcji tej formuły - w przypadku konfliktu zaczyna oznaczać ostateczne zerwanie kontaktów:

Żegnam cię na zawsze (rozgniewany szlachcic do brata, który odbił mu narzeczoną, II poł. XVIII w.) RzewLis2, 56;

Żegnam cię więc, żałuję, jednak szczęścia życzę (szlachcic do niewiernej narzeczonej, I poł. XIX w.) FrDz1, 56;

Żegnam, wychodź pan (szlachcic do szlachcica w gniewie, poł. XIX w.) BujSt 224.

\footnotetext{
20 Ibidem, s. 65.

21 E. Umińska-Tytoń, Polszczyzna ..., s. 170.
} 
Żegnam wypowiadała osoba inicjująca zakończenie kontaktu, a odpowiedzią był zwykle inny akt grzecznościowy:

- Żegnam.

- Papkin nóżki ściska. FrDz2, 89.

Niemal zawsze żegnam łączono z adresatywami w bierniku i w wołaczu. Najczęściej takie formuły obserwujemy w dialogach osób o podobnej randze pragmatycznej:

Żegnam cię, bracie drogi (bracia, II poł. XVIII w.) RzewLis2, 335;

Żegnam cię, bywaj zdrów - szczęśliwej podróży (przyjaciel do przyjaciela, lata 80. XVIII w.) ZabF 103;

Żegnam was tedy, kochana żonko i dzieci (podsędek, II poł. XVIII w.) BDr 152;

Żegnam Cię pani na zawsze (szlachcic do byłej narzeczonej, początek XIX w.) WójN 92;

Żegnam cię i życzę wesołej podróży (przyjaciel do hrabiego, lata 30. XIX w.) RaRa 188;

Idę walczyć, żegnam was na zawsze, bo po śmierć idę (szlachcic do rodzeństwa przed pójściem do powstania listopadowego, 1830) GirtOp1, 451;

Żegnam cię (przyjaciel do przyjaciela, I poł. XIX w.) KorzKom 54; (bankier do regenta, lata 40. XIX w.) RusWar3, 121;

Żegnam cię na długo, może na zawsze w tem życiu (szlachcic do ukochanej, lata 40. XIX w.) OsP1, 115;

Żegnam panie (hrabia do szlachcianek, I poł. XIX w.) KorzKom 355;

Żegnam (cenzor do autora, I poł. XIX w.) PamWoź 31;

Żegnam panów (szlachcic wychodząc z salonu, I poł. XIX w.) DzierzS 34;

Żegnam waści i życzę, aby ci się w nowym zawodzie powiodło (w złości starosta do porucznika, poł. XIX w.) SkarbSt 95;

Żegnam cię i zamawiam sobie na inny raz twoje towarzystwo (dziennikarz do kolegi, poł. XIX w.) KuczGodz 23;

Żegnam panią (szlachcic do znajomej, poł. XIX w.) CieszP 295;

Żegnam pana (mieszczanin do inżyniera, poł. XIX w.) KraszDz 119;

Żegnam panów moich (mieszczanin do znajomych, poł. XIX w.) KorzRep 62.

Akt ten był używany także wtedy, gdy odbiorca posiadał niższy status pragmatyczny od nadawcy. Formuły wyglądają bardzo podobnie do stosowanych w relacji symetrycznej:

Żegnam się z wami, szanowni wojownicy, i proszę was o odpuszczenie, jeżelim którego z was kiedy obraziła. Polecam się na zawsze waszej pamięci. (księżna do wojska, II poł. XVIII w.) PamRadz 203 - w tym wypadku żegnam jest tylko częścią dłuższej oracji;

Żegnam was, bo godzinę za plus minus, już mnie stąd wyruszyć trzeba (książę do szlachty, II poł. XVIII w.) RzewLis2, 16;

Żegnam Acani (hrabia do mieszczki, lata 40. XIX w.) RusWar3, 136;

Żegnam was moje panny (szlachcianka do młodszej siostry i jej guwernantki, poł. XIX w.) DmNa 76; 
Żegnam pannę Bogunię (poeta do córki szewca, I poł. XIX w.) DzierzS 115; A teraz żegnam (hrabia do szlachcica, poł. XIX w.) ŁozDw 340;

Żegnam aspana (marszałek do rotmistrza, poł. XIX w.) BujSt 290;

Żegnam panią, droga panno Wando (szlachcic do córki leśniczego, poł. XIX w.) CieszP 285.

Z ekscerpowanych tekstów wynika, że zdecydowanie rzadziej za pomocą żegnam zwracano się do osób o wyższej randze pragmatycznej:

Żegnam cię, mości hrabio (kapitan, I poł. XIX w.) ŁozHis 129;

Żegnam cię, hrabio (lekarz, I poł. XIX w.) KorzDram 122;

Ja panią żegnam (pułkownik do generałowej, I poł. XIX w.) KorzWd 41;

Żegnam cię (syn do ojca, lata 40. XIX w.) RuWar2, 168.

\subsubsection{W listach}

Nowością w stosunku do epoki średniopolskiej było używanie pierwotnie wyłącznie ustnej formuły również w zakończeniach listów. Z badanego materiału wyraźnie wynika, że upowszechnianie się tego rodzaju subskrypcji nastapiło dopiero w XIX wieku, gdyż wcześniejsze przykłady są bardzo nieliczne. Pisano w ten sposób głównie do rodziny, przyjaciół - do osób, z którymi nadawcę listu łączyły bliskie relacje. W przypadku epistolografii mamy do czynienia z dużo większą różnorodnością formuł niż w konwersacjach. Forma pisemna sprzyjała też tworzeniu dłuższych fraz. Do rzadkości należało zwykłe żegnam cię, które najwyraźniej było zbyt zdawkowe:

Żegnam cię it.d. (znajomy do Józefa Kraszewskiego, 1842) KorGrab1, 138;

Żegnam cię (Teofil Januszewski do przyjaciela, 1829) LisRS 385; (Zygmunt Krasiński do przyjaciela, 1841) KrasMał 6;

Obudowa etykietalna zwykle jest tu bogatsza niż w aktach ustnych: pojawiają się okoliczniki, a do adresatywów dodawane są formy atrybutywne pozytywnie wartościujące odbiorcę:

Żegnam cię Malwino, nad wszelkie uwielbienie (szlachcic w liście do ukochanej, II poł. XVIII w.) WirMal 36;

Żegnam cię, droga siostro (brat do siostry, I poł. XIX w.) BłP 378;

Żegnam cię jeszcze raz drogi Wacławie (Seweryn Goszczyński do przyjaciela, 1824) GoszLis 3;

Żegnam Pana przyjaźnie (Aleksandra Bécu do Antoniego Odyńca, 1827) LisRS 349;

Żegnam cię serdecznie (brat do brata, 1831) PamL 44;

Mamo droga, żegnam ciebie (Juliusz Słowacki, 1831) KorSł 13;

Żegnam cię, drogi mój Stasiu (Stanisław Trentowski do znajomego, 1836) TrenLis 4;

Mój aniele, bracie, żegnam cię (Narcyza Żmichowska, 1838) ŻmLis1, 73;

Czuciem więc żegnam ciebie (Zygmunt Krasiński do przyjaciela, 1840) KraPot 88; 
Żegnam cię, ukochany Panie (Stanisław Trentowski do wydawcy, 1841) TrenLis 58;

Żegnam Cię tedy z duszy i z serca (lekarz do przyjaciela, 1842) MorLis 68;

Do przyszłego listu żegnam cię, mój Erazmie (Narcyza Żmichowska do brata, 1844) ŻmLis 1, 168;

Żegnam cię, mój drogi (Teofil Lenartowicz do przyjaciela, 1850) LiLen 9;

Żegnam cię droga towarzyszko moich lat młodzieńczych (przyjaciółka do przyjaciółki, poł. XIX w.) DmNa 175;

Żegnam Bianko, nie na długo (Narcyza Żmichowska do przyjaciółki, 1860) ŻmLis2, 162 .

Typowym zjawiskiem w badanej epistolografii jest następowanie po żegnam kolejnych aktów etykietalnych:

Żegnam kochaną Ciocię Dobrodziejkę, ściskamy ją wszystko troje serdecznie, racz nas też kochać cokolwiek (arystokratka w liście do księżnej, 1790) TańDzien 159;

Żegnam Pana życząc mu zawsze najlepszego powodzenia (Salomea Słowacka do Antoniego Odyńca, 1826) LisRS 163;

Żegnam Pana i od wszystkich moich ukłony mu oświadczam (Salomea Słowacka do Antoniego Odyńca, 1827) LisRS 247;

Żegnam Pana i proszę, żeby mi odpisał prędko (Aleksander Bécu do Antoniego Odyńca, 1828) LisRS 354;

Żegnam Cię, kochany panie Fryderyku, życząc z serca zdrowia i wszystkiego dobra (Stefan Witwicki do Fryderyka Chopina, 1831) ChopKor1, 180;

Żegnam Cię, życząc Ci sercem spokojności (żona Teofila Januszewskiego do przyjaciela, 1832) LisRS 392;

Żegnam Kochanego Papę, po sto razy całując Jego rączki (Józef Kraszewski do ojca, 1835) KraszLis 51;

Żegnam cię, mój najdroższy, całuję, pieszczę, myślą do serca przyciskam. Bądź zdrów. (Narcyza Żmichowska do brata, 1838) ŻmLis1, 100;

Żegnam do przyszłego listu i całuję rączki Papy i Mamy (Józef Kraszewski do matki, 1839) KraszLis 89;

Żegnam cię i ściskam (Seweryn Goszczyński do przyjaciela, 1840) GoszLis 113;

Teraz żegnam i życzę wszelkiej pomyślności (Stanisław Trentowski do znajomego, 1841) TrenLis 50;

Żegnam Cię i całuję, mój najdroższy, niech ci Bóg da zdrowie i wszelką pomyślność (matka do Fryderyka Chopina, 1848) ChopKor1, 232;

Żegnam cię teraz do rychłego zobaczenia tylko (Narcyza Żmichowska, 1859) ŻmLis2, 144.

W zebranych subskrypcjach kilkakrotnie pojawia się też schemat żegnam + narzędnik:

Żegnam cię, panie, z żalem przywiązanego syna (szlachcic do ojca niedoszłej narzeczonej, 1826) SkarbSt 76; 
Żegnam najczulszym uściśnieniem (Narcyza Żmichowska do brata, 1839) ŻmLis1, 122;

Czuciem więc żegnam ciebie (Zygmunt Krasiński do przyjaciela, 1840) KrasPot 88;

Żegnam Cię mój kochany Mieczysławie życzeniem dobrej myśli (Wincenty Pol do przyjaciela, 1845) LisPol 138;

A teraz żegnam Panią z prawdziwym uczuciem wdzięczności za dobre serce (znajomy do Pauliny Wilkońskiej, 1855) WilkWsp 320.

\subsection{2. „kłaniam (się)"}

\subsubsection{W rozmowach}

Formuła ta pełniła nie tylko funkcję powitania, ale mogła być również pożegnaniem. O ile w pierwszej połowie XVIII w. miała ceremonialny charakter ${ }^{22}$, to w początkach doby nowopolskiej zdecydowanie już go zatraciła - badane teksty pokazują, że często była ona wręcz zdawkowa i stosowana w sytuacji ochłodzenia relacji z powodu konfliktu. Większość odnotowanych użyć pochodzi z XVIII wieku. Postać formalna takich pożegnań jest dość zróżnicowana. Mógł to być sam czasownik bez żadnych ozdobników:

Kłaniam (szlachcic do szlachcica na pożegnanie, II poł. XVIII w.) BohK1, 342; (podstolina do natrętnego zalotnika, II poł. XVIII w.) ZabF 47; (szlachcic do komisanta I poł. XIX w.) FrDz1, 52.

Zwykle jednak pojawia się mniej lub bardziej rozwinięta obudowa etykietalna. Standardowym ozdobnikiem były przysłówki uniżenie/najniżej:

Kłaniam jak najniżej (kupiec do dłużnika, II poł. XVIII w.) BohK1, 190; (lokaj do szlachcica, II poł. XVIII w.) BohK2, 76;

Kłaniam uniżenie (żona do męża w złości, II poł. XVIII w.) ZabF 96; (rozgniewany szlachcic do swego plenipotenta, II poł. XVIII w.) WybDr 85;

Kłaniam się uniżenie (szlachcic do szlachcica, II poł. XVIII w.) KK 238.

Cytowany materiał dowodzi, że okoliczniki te mają już wyłącznie konwencjonalny charakter - nie są wykładnikiem niższości nadawcy wypowiedzi, skoro stosowały je osoby o wyższej randze pragmatycznej od odbiorcy. O petryfikacji takich formuł świadczy także fakt, że używano ich nawet w gniewie - zapewne miały wtedy ironiczny wydźwięk.

Jedynie raz pojawia się inny przysłówek:

Kłaniam serdecznie (szlachcic do służącej, która mu pomogła, II poł. XVIII w.) BohK2, 372. W tym wypadku wyjście poza schemat jest zapewne wyrazem autentycznej wdzięczności do adresatki.

${ }^{22}$ M. Cybulski, Obyczaje językowe..., s. 70. 
Drugim częsty elementem obudowy etykietalnej tego aktu są formy adresatywne w celowniku lub w wołaczu:

Kłaniam waszmość panu (siostra do brata ze złością, II poł. XVIII w.) BohK2, 60; (obrażony guwerner do przyjaciela, II poł. XVIII w.) BohK1, 166;

Kłaniam, kochany przyjacielu (dłużnik do kupca, II poł. XVIII w.) BohK1, 190 ;

Kłaniam, kochany Gospodasiu (dłużnik do podstarościca, II poł. XVIII w.) BohK1, 193;

Kłaniam WaćPaństwu (szlachcianka do znajomych, pocz. XIX w.) NiemDom 28.

Najbardziej rozbudowane formuły zawierają zarówno adresatywy, jak i okoliczniki:

Kłaniam waszmość panu jak najuniżeniej (szlachta, II poł. XVIII w.) BohK2, 54;

Kłaniam jak najniżej waszmość panu (szlachta, II poł. XVIII w.) BohK1, 310.

\subsubsection{W listach}

W przypadku epistolografii ktaniam zwykle nie jest przeznaczone dla adresata, ale dla osób trzecich:

JMci samej prześlicznie kłaniam i w rękę prawą całuję (Ignacy Krasicki do brata, 1760) KKor 45;

Wszystkim kłaniam się (siostra do Karola Radziwiłła, 1773) MorDiar 123;

Wszystkim łaskawym kłaniam się (Franciszek Karpiński do przyjaciółki, 1775) KarpKor 11;

JWPannie Kluczyńskiej kłaniam się najuniżeniej (Franciszek Karpiński do przyjaciółki, 1775) KarpKor 11;

Wielmożnemu Pułkownikowi Cieńskiemu najuniżeniej kłaniam (Franciszek Karpiński, 1784) KarpKor 26;

J.p. Stanisławowej, Krysi serdecznie kłaniam się (Grzegorz Piramowicz do Ignacego Potockiego, 1785) KorPot 144;

Wszystkim razem serdecznie kłaniam (kasztelanowa do marszałka, 1793) LisKos 272;

Lelewelowi i Gołuchowskiemu ktaniam się (Salomea Słowacka do Antoniego Odyńca, 1826) LisRS 153;

Franusia ściskam i Galetowi kłaniam (Zygmunt Krasiński do przyjaciela, 1838) KraPot 16;

Jasinkowiczom najniżej kłaniam (lekarz do przyjaciółki, 1849) MorLis 137.

Nieco bardziej ceremonialny wariant to zasytać ukłony:

Jejmość Dobrodziejce najniższy ukłon zasyłam (Grzegorz Piramowicz do Ignacego Potockiego, 1779) KorPot 45; 
Całej Rodzinie Pana i wszystkim łaskawym, co pamiętają o mnie, najprzyjaźniejsze ukłony zasyłam (Salomea Słowacka do Antoniego Odyńca, 1828) LisRS 307.

W jednym z ówczesnych poradników dobrych manier czytamy, że: „Niemniej wystrzegać się trzeba, pisząc do osoby, dla której się ma uszanowanie, obowięzywać ją aby się kłaniała, lub przesyłała ukłon trzeciej osobie"23. W praktyce takie akty pojawiają się w listach do rodziny i bliskich:

Kłaniaj się ode mnie twojej rodzinie (Jan Czeczot do Adama Mickiewicza, 1819) KorFil 23;

Wszystkim znajomym kłaniaj się (Franciszek Mickiewicz do Aleksandra Mickiewicza, 1820) KorFil 162;

Kłaniajcie się ode mnie jak najpiękniej Olesi (Juliusz Słowacki do matki, 1831) KorSł 37;

Kłaniaj znajomym, panią Lenain uściskaj ode mnie (Narcyza Żmichowska do brata, 1839) ŻmLis1, 112;

Żoneczce kłaniaj i rączkę pocałuj (lekarz do przyjaciela, 1848) MorLis 128;

Oświadcz ode mnie ukłon niegrzecznemu panu Adamowi (Maria Puttkamerowa do siostrzeńca, 1822) KorFil 284.

W celu nadania większej uprzejmości takim frazom rozkaźnik bywa zastępowany formalnymi wykładnikami prośby:

Proszę J. W. Pisarzowi serdecznie kłaniać (kasztelanowa do siostrzeńca, 1789) LisKos 199;

Proszę się jak najniżej WJPanu Jgnacemu Zanowi, łaskawemu Dobrodziejowi, ukłonić (Adam Mickiewicz do Tomasza Zana, 1820) KorFil 108;

Proszę bardzo kłaniać się ode mnie panu Krzeczkowskiemu (Zygmunt Krasiński do plenipotenta, 1851) KrasLis 50.

W ekscerpowanych listach, choć rzadko, to jednak zdarzają się subskrypcje, w których omawiane tu akty były kierowane bezpośrednio do adresata:

Wszyscy Panu zasyłamy najprzyjaźniejsze ukłony (Salomea Słowacka do Antoniego Odyńca, 1827) LisRS 222;

Kłaniam się Panu szczerze (Elżbieta Krasińska w liście do plenipotenta, 1854) KraLis 263;

Wszyscy Ci przesyłamy ukłony najpiękniejsze, Tobie i żonie Twej, i Kazi (Józef Kraszewski do brata, 1859) KraszLis 417.

${ }^{23}$ Wychowaniec dziewiętnastego wieku czyli przepisy przystojności i dobrego tonu w pożyciu towarzyskiem, zebrał i według najlepszych wzorów francuzkich ułożył P.E. Leśniewski, Warszawa 1843, s.174. 


\subsection{3. „upadam do nóg/stóp” i przekształcenia}

\subsubsection{W rozmowach}

Formuła, która pierwotnie pojawiała się jedynie w listownych subskrypcjach, w epoce nowopolskiej zaczyna być również ustnym pożegnaniem. Akt ten szybko spospolitował się i w badanym okresie nie jest już wyznacznikiem niższego statusu nadawcy. O konwencjonalności tego rodzaju pożegnań może świadczyć taka wymiana uprzejmości:

- Upadam do nóżek mojej pani.

- Uniżona sługa waćpana. (szlachcic do narzeczonej, II poł. XVIII w.) BDr 92.

W poradniku dobrych manier z 1862 takie frazy spotkały się już z jednoznacznym potępieniem: „Żyją jeszcze silnie naiwne i komiczne formułki pożegnalne: »padam do nóg«, »całuję rączki i nóżki« itp."24

Pożegnanie to powszechnie stosowano w relacji symetrycznej - podobnie jak w przypadku powitań z wykorzystaniem tej frazy. Swoim zasięgiem objęło wszystkie warstwy społeczne - było używane zarówno przez szlachte, jak i przez chłopów. Formuła odznaczała się dużą stabilnością. Modyfikacji członu werbalnego w zasadzie nie ma, poza pojedynczym ścielę. Do nóg bywa zastępowane hipokorystycznym do nóżek. Czasami pojawia się szyk przestawny.

Zaskakująco ubogo, w porównaniu z aktami powitań zawierającymi tę frazę, prezentuje się tutaj obudowa etykietalna - jedyne ozdobniki to niezbyt liczne formy adresatywne i zupełnie wyjątkowo przymiotniki. Najwyraźniej inicjowanie kontaktu bardziej sprzyjało wylewności niż kończenie go.

W przypadku, gdy interlokutorzy zajmowali podobne miejsce w hierarchii społecznej formuły wyglądały następująco:

Upadam tedy do stóp waszmość pani dobrodziki (szlachcic do szlachcianki, II poł. XVIII w.) BohK2, 41;

Upadam do stóp waszmość pana (szlachta, II poł. XVIII w.) BohK1, 310;

Padam do nóżek (porucznik do szlachcianki, lata 20. XIX w.) SkarbSt 46;

Do nóżek upadam (szlachcic do szlachcica, I poł. XIX w.) FrDz1, 112;

Upadam do nóg (regent do bankiera, lata 40. XIX w.) RusWar3, 121;

Upadam do nóg pani (marszałek na pożegnanie do podkomorzanki, poł. XIX w.) BujSt 290;

Do nóg upadam wikarego dobrodzieja (mieszczanin do księdza, poł. XIX w.) KraszDz 421;

Upadam do nóg (szlachcic do szlachty, poł. XIX w.) KraszDwa 296.

${ }^{24}$ F. Betlejczyk, O języku towarzyskim, Kraków 1862, s. 5. 
Bardzo podobną postać mają pożegnania kierowane do osób o wyższej randze pragmatycznej od nadawcy - próżno szukać tu jakichś dodatkowych wykładników niższości:

Upadam do nóg pani (sługa do podstoliny, II poł. XVIII w.) ZabF 117;

Upadam do stóp waszmość pana (sługa do szlachcica, II poł. XIX w.) BohK2, 224;

Upadam do stóp JWPanu (mieszczka do hrabiego, lata 40. XIX w.) RusWar3, 136;

Upadam do nóg pani Baronowej (szlachcianka, lata 40. XIX w.) RusWar2, 89;

Do nóg upadam wielmożnemu panu (chłop do dziedzica, lata 40. XIX w.) GirtOp2, 205;

Upadam do nóg (rządca do sędziego, poł. XIX w.) ŁozDw 240;

Ściele mnie pod nogi (sługa do notariusza, I poł. XIX w.) FrDz2, 271 jedyny może przykład intensyfikowania uniżoności za pomocą czasownika ścielę.

\subsubsection{W listach}

Doba nowopolska jest okresem, gdy tego typu subskrypcje wychodzą z użycia. Są jeszcze dość popularne w drugiej połowie XVIII wieku, natomiast w XIX należą już do rzadkości. Być może częściowo zostały wyparte przez formułę $c a$ tuję nogi, którą spotykamy w epistolografii całego badanego okresu, ale i jej frekwencja nie jest wysoka.

Wariantywność formuł jest tu zdecydowanie większa niż w przypadku aktów oralnych. Przykładem twórczego przekształcania standardowych formuł mogą być subskrypcje autorstwa Adama Naruszewicza:

Uniżam się do stóp Pańskich wyznając, żem jest Jaśnie Wielmożnego WPana Dobrodzieja obowiązanym i najniższym sługą (do starosty żmudzkiego, 1773) KorNar 19;

Upadam do nóg najosobliwszego Dobrodzieja mego, oświadczając się, żem do zgonu życia Jaśnie Wielmożnego WPana Najłaskawszego Dobrodzieja najżyczliwszym i najniższym sługą (do Stanisława Augusta Poniatowskiego, 1775) NarLis 32;

Ja się za nogi trzymam jednego pana (do Stanisława Augusta Poniatowskiego, 1781) NarLis 490;

Schylam głowę moję u nóg Pańskich (do Stanisława Augusta Poniatowskiego, 1789) KorNar 334;

Rzucam mnie pod nogi Pańskie prosząc o przysłanie mi tego biletu żądanego (do Stanisława Augusta Poniatowskiego, 1790) KorNar 375;

Ścielę głowę moję u nóg, przy których chcę ją przy śmierci położyć (do Stanisława Augusta Poniatowskiego, 1790) KorNar 376. 
Jednak nie tylko w listach nadwornego poety możemy obserwować dużą rozmaitość formalną epistolarnych subskrypcji:

Ściskam serdecznie nogi JWMP Dobr. z nieoderwanem nigdy przywiązaniem (generał w liście do hetmana Ksawerego Branickiego, 1760) LisJak 31;

Upadam do nóg obojga JWMMPDobrodzieja (generał w liście do hetmana Ksawerego Branickiego, 1762) LisJak 57;

Ściskam nóżki i zostaję z serca przywiązaną sługą (kasztelanowa do księżnej, 1764) LisKos 61;

A teraz upadam do nóg WKMci (Ksawery Branicki do Stanisława Augusta Poniatowskiego, 1768) KonfB 147;

Księciu staroście do nóg upadam (szlachcianka, 1773) MorDiar 237;

Upadam do nóg Pańskich JWWP Dobrodzieja (działacz KEN-u do Ignacego Potockiego, 1778) KorPot 36;

Rzucam mię do stóp pańskich JWWMP Dobrodzieja najobowiązańszy i najniższy podnóżek (prefekt szkół do Ignacego Potockiego, 1780) KoPot 88;

Upadam do nóg Wielmożnej Pułkownikowej Cieńskiej Dobrodziejki, jej łasce się polecam (szlachcianka do żony magnata, 1784) KarpKor 26;

Ścielę się pod stopy Pańskie (Stanisław Trembecki do księcia, 1801) TremNie 225;

Ściele mię pod stopy (Stanisław Trembecki do księcia, 1802) TremNie 228;

Do nóg Jej razem z Zofią i Kostusią upadamy i łasce się Jej polecamy (Józef Kraszewski do babki, 1839) KraszLis 91;

Zawsze w nadziei widzenia Drogiej Babuni Dobrodziejki, upadam do nóg Jej i polecam się łasce, zostając zawsze najprzywiązańszym wnukiem (Józef Kraszewski, 1842) KraszLis 106.

W członie werbalnym widoczna jest duża rozmaitość czasowników oraz gradacja ich intensywności: schylam, składam, ściskam, trzymam, uniżam sie, upadam, ścielę, rzucam. Na podstawie badanych listów nie można już jednak wskazać konkretnej zależności między używaną formułą a pozycją społeczną odbiorcy. Jest to dobrze widoczne choćby na podstawie korespondencji Naruszewicza, który pisząc do Stanisława Augusta Poniatowskiego, raz królewskie nogi trzyma, a kiedy indziej się pod nie $r z u c a^{25}$. Świadczy to o daleko posuniętej konwencjonalizacji wszystkich tych formuł. Wyznacznikiem wysokiej pozycji społecznej adresatów są tu adresatywy w postaci mocno rozbudowanych grup imiennych.

Używanie takich aktów etykietalnych nie ogranicza się w badanym okresie tylko do sytuacji, gdy list był skierowany do osoby o wyższej randze od nadawcy. Pisano w ten sposób również do równych sobie, choć znacznie rzadziej:

${ }^{25}$ Ewentualnie można by tu wskazać na pewne uwarunkowania sytuacyjne: Naruszewicz $r z u$ cał się pod królewskie nogi, gdy zależało mu na spełnieniu jakiejś prośby. 
Wszelkie losy moje poruczam ojcowskiemu błogosławieństwu i wraz z żoną moją uniżam się do stóp (Karol Radziwiłł do Wacława Rzewuskiego, 1764) RzewKron 231;

Upadam do nóg JM Pani Łąckiej, mojej dobrodziejce (Franciszek Karpiński do znajomej, 1775) KarpKor 11;

Upadam ci do stóp (Jan Śniadecki do znajomego, 1791) ŚniaLis 29;

Schylam się do nóg JWJMć Pani Starościny (Franciszek Karpiński do znajomej, 1799) KarpKor 102;

Ścielę się do Jej nóg jako wierny sługa (lekarz do przyjaciółki, 1838) MorLis 35 .

Warto zauważyć, że formuły padam do nóg i całuje raczki, choć kostnieją i rozszerzają społeczny zasięg użycia, to jednocześnie zachowują swój honoryfikatywny charakter. Są elementem eleganckiego języka warstw wyższych, charakteryzują nadawcę jako człowieka grzecznego, w każdej relacji, zarówno symetrycznej w obrębie własnej sfery, jak i asymetrycznej wobec niżej stojących.

\subsection{4. „caluję..." i przeksztalcenia}

Możemy wydzielić tu dwa typy formuł: całuję + biernik nazwy części ciała oraz caluje + biernik zaimka osobowego adresata. Pierwszy z nich, to znane już w okresie średniopolskim frazy subskrypcji listownych w rodzaju catuję ręce, które następnie weszły do języka mówionego i w dobie nowopolskiej pełnią również funkcję powitań. Natomiast drugi typ występuje wyłącznie w epistolografii i jak pokazują ekscerpowane listy, wykształcił się dopiero pod koniec osiemnastego wieku.

1. O ile schemat całuję + biernik nazwy części ciała stał się w badanym okresie standardowym konwersacyjnym aktem powitalnym, to w roli ustnych pożegnań jest bardzo słabo poświadczony w analizowanych tekstach:

Catuje raczki panów moich (lichwiarka do szlachciców, II poł. XVIII w.) CzarKom 176;

Całuję nuzi pani dobrodziejce, ruci (sic!) caluje (poczmistrz do szlachcianki, poł. XIX w.) CieszT 139.

W przypadku korespondencji materiał jest bogaty. Zwykle pożegnanie było kierowane bezpośrednio do adresata, ale mogło też być przeznaczone dla osób trzecich:

Za pozwoleniem Pani caluje raczki WW Skarbnikówien Wiktorii i Ludwiki (Franciszek Karpiński do znajomej, 1775) KarpKor 11;

Jejmość dobrodziejki rączi całuje (Grzegorz Piramowicz do Ignacego Potockiego, 1778) KorPot 33;

Wielmożnej Siostrzyczki Twojej do nóg upadam WJMości Dobrodziejki, chociaż nieznajomej catuję nogi (Franciszek Karpiński w liście do przyjaciela, 1781) KarpKor 18; 
JWJM Pani Miecznikowej Koronnej nogi całuję (Hugo Kołłątaj do barona, 1792) KołLis1, 11;

Babuni Starszej raczki, nóżki całuję (Józef Kraszewski w liście do babki, 1827) KraszLis 19;

Papy nóżki i rączki całuję (Józef Kraszewski do matki, 1832) KraszLis 41;

Całuję ręce dziada (Juliusz Słowacki w liście do matki, 1834) KorSł 196;

Mamy kochanej rączi całuje (Józef Kraszewski w liście ojca, 1835) KraszLis 51 ;

Żonie twojej raczki caluje (Teofil Lenartowicz do przyjaciela, 1850) LisLen 8 .

Występował również wariant z członem werbalnym w trybie rozkazującym:

Ucałuj ode mnie panów Michała i Józefa (Adam Mickiewicz do Tomasza Zana, 1822) KorFil 292;

Szanownych rodziców nogi ucałuj (Seweryn Goszczyński do przyjaciela, 1823) GoszLis 1;

Papę Twego też ucałuj ode mnie i podziękuj za wywar (Fryderyk Chopin do kolegi, 1825) ChopKor1, 47;

Kochana Mamo, ucałuj ode mnie po tysiąc razy rączki kochanej pani Michalskiej (Juliusz Słowacki do matki, 1830) KorSł 7;

Żonie raczki ucałuj i podziękuj za pamięć (Teofil Lenartowicz do przyjaciela, 1850) LisLen 12;

Mamy rązki i nóżki ucałuj (Józef Kraszewski do brata, 1853) KraszLis 248.

Choć akty te wywodzą się z przeznaczonej tylko dla monarchy formuły $c a-$ tuję rękę, to jak pisze M. Cybulski ${ }^{26}$, w XVIII wieku zaczęto kierować je również do osób, które choć nie posiadały królewskiej rangi, to jednak miały pozycję dużo wyższą od nadawcy. Druga połowa XVIII wieku przynosi dalsze i szybkie pospolitowanie się takich subskrypcji.

$\mathrm{W}$ badanym materiale odnajdujemy listy do króla $\mathrm{z}$ tradycyjnym zakończeniem całuję ręke, ale pojawia się także nowy wariant $\mathrm{z}$ dopełnieniem nogi:

A teraz całuję nogi WKMci i jestem z najgłębszym respektem (Ksawery Branicki do Stanisława Augusta Poniatowskiego, 1768) KonfB 82;

Więcej nie mam co donieść, tylko całuję nogi WKMci i jestem z głębokim respektem (Ksawery Branicki do Stanisława Augusta Poniatowskiego, 1768) KonfB 82;

Całuję nogi Pańskie (Adam Naruszewicz do Stanisława Augusta Poniatowskiego, 1778) KorNar 288;

Catuję rękę W.K.M. (Adam Naruszewicz do króla, 1780) NarLis 484;

Cahuję z najgłębszym respektem rękę W.K.M. (Adam Naruszewicz do króla, 1781) NarLis 490;

Catuję rękę Pańską (Adam Naruszewicz do króla, 1781) KorNar 323.

${ }^{26}$ M. Cybulski, Obyczaje językowe..., s. 78. 
W celu zwiększenia grzeczności takiej subskrypcji często dołączano formułę jestem z respektem oraz stosowne okoliczniki.

Inne przykłady takich subskrypcji w relacji asymetrycznej dowodzą, że w badanym czasie były uważane za odpowiednie w listach do przełożonych i chlebodawców:

Całuję dobroczynne ręce JWWPana Dobrodzieja z dozgonnym najuniżeńszym uszanowaniem i wdzięcznością zostając JWWMPana Dobrodzieja najniższym sługą (Stanisław Konarski do Wacława Rzewuskiego, II poł. XVIII w.) KonL 216;

Całuję stopy Pańskie JWPDobrodzieja najniższy podnóżek (plenipotent do Ignacego Potockiego, 1782) KorPot 126;

Stopy JWMPDobr. caluje z tym respektem, z którym mu całe życie moje na usługi jego poświęcone (generał do hetmana Ksawerego Branickiego, 1760) LisJak 28;

Catuje po milion razy nogi Obojga Państwa Dobrodziejstwa (oficjalista do ziemianina, 1821) ChrzPam 181;

Catuję nogi Obojga Państwa Dobrodziejów (oficjalista do ziemianina, 1826) ChrzPam 189;

Caluję twe ręce, Ojcze, i Braci pozdrawiam (zakonnik do przełożonego, 1849) LisDuń 5.

Ten rodzaj epistolarnego pożegnania był również chętnie stosowany w listach do krewnych. Adresata od piszącego nie dzieliła w tym wypadku duża różnica pozycji społecznej - wyższa ranga pragmatyczna odbiorcy wynikała zwykle jedynie z faktu, że były to osoby starsze, którym wypadało okazać szacunek. Pisano tak nawet do bardzo bliskich osób, o czym świadczą hipokorystyczne formy adresatywne. Używane w subskrypcjach zdrobnienia rzeczownika np. rqczki, nóżki pełnią funkcję ekspresywną - wyrażają bliskość relacji. Często przełamywano schemat, łącząc więcej niż jedno dopełnienie, dodawano kolejne formuły oraz okoliczniki podkreślające przywiązanie do adresata:

Księcia stryja całuję rqczki, pamięci mu oddaję (bratanek do stryja, 1773) MorDiar 236;

Teraz caluję nogi braterskie, oddaję się jego afektowi (siostra ${ }^{27}$ do Karola Radziwiłła, 1773) MorDiar 233;

Całuję nogi brata dobrodzieja (siostra do Karola Radziwiłła, 1773) MorDiar 237;

Raczki Papie, Mamusi caluje jako wszystkie siostry serdecznie ściskam (porucznik do rodziców, 1812) BielBon 67;

Całuję rączki i nóżki Najukochańszych Rodziców (Fryderyk Chopin, 1824) ChopKor1, 38;

${ }^{27}$ Brat posiadał wyższą rangę od siostry z racji płci. 
Kochana mamo, całuje serdecznie twoje rączki i nóżki (Juliusz Słowacki, 1831) KorSł 23;

Całuję rączi, oczka, ściskam ciebie serdecznie i żegnam (Juliusz Słowacki do matki, 1835) KorSł 254;

Całuję rązki i nóżki Papy i Mamy i polecam się ich łasce (Józef Kraszewski, 1844) KraszLis 120;

Całuje po tysiąc razy raczki Ojca Dobrodzieja i polecam siebie i moich pamięci Jego, sercu i błogosławieństwu (Józef Kraszewski, 1851) KraszLis 212;

Po sto razy całuję raczki Mamy Dobrodziejki (Józef Kraszewski, 1853) KraszLis 234;

Do widzenia, najdroższa Mameczko. Całuję i ściskam rączki i nóżki (Helena Modrzejewska, 1862) KorMod 44.

Ostatecznym dowodem daleko posuniętej konwencjonalizacji takich subskrypcji w badanym okresie jest ich obecność w korespondencji osób o takim samym statusie społecznym:

Caluję nogi (Franciszek Karpiński do znajomych pań, 1775) KarpKor 10;

Całuję twe raczki, a matulki nóżki (Tadeusz Kościuszko do narzeczonej, kon. XVIII w.) LM 136;

Caluje raczki Twoje (Józef Szymanowski do starościny wyszogrodzkiej, 1792) SzymLis 24;

Całuję tysiąc razy rączki Pani mojej (Józef Szymanowski do starościny wyszogrodzkiej, 1792) SzymLis 21;

Całuje raczki Pani jak najczulej, zawsze wierny i przywiązany sługa (Józef Szymanowski do starościny, 1795) SzymLis 80;

Raczki Pani całuje, jako wierny przyjaciel i dobry sługa (lekarz do przyjaciółki, 1838) MorLis 32;

Raczki całuję, dziatki uściskam (lekarz do przyjaciółki, 1839) MorLis 46;

Ręce twoje całuję i ściskam Ciebie serdecznie (Adam Mickiewicz do przyjaciółki, poł. XIX w.) MicKon 17;

Ze czcią całuję raczki Pani (Władysław Syrokomla do Pauliny Wilkońskiej, poł. XIX w.) WilkWspo 277;

Całuje Twoje raczki i oddaje się z całą rodziną Twej pamięci poczciwej (przyjaciel do Pauliny Wilkońskiej, 1852) WilkWsp 108.

Ciekawymi przykładami indywidualnych przekształceń standardowej formuły są zakończenia listów Hugona Kołłątaja do Tadeusza Kościuszki: Całuje szanowne serce Przyjaciela mego (1793) KołLis2, 80; Józefa Szymanowskiego do starościny wyszogrodzkiej: Całuję raczki ślicznie i zdejmuję do tego aktu rękawiczki (1797) SzymLis 96, oraz Narcyzy Żmichowskiej do przyjaciółki: Całuje śliczne zabki twoje (1846) ŻmLis2, 40.

2. W odróżnieniu od już omawianych formuł schemat całuje + biernik zaimka osobowego adresata nie zawiera w sobie żadnych wykładników niższości nadawcy. O ile całowanie np. w rękę było wyrazem poddaństwa i sza- 
cunku, to całowanie kogoś (bez określania konkretnej części ciała) jest wyrazem bliskich czy wręcz intymnych relacji. Stąd takie subskrypcje spotykamy wyłącznie w listach do krewnych i przyjaciół, a nigdy do osób o wyższej randze od nadawcy. Najczęstszy element obudowy etykietalnej tego aktu, to okolicznik serdecznie:

Całuję cię serdecznie i statecznej mnie przyjaźni polecam (Jan Śniadecki do znajomego, 1788) ŚniadLis 7;

Całuję Cię serdecznie, łasce mnie Twojej i przyjaźni oddając (Jan Śniadecki do przyjaciela, 1791) ŚniaLis 27;

Catuję Cię serdecznie. Pamiętaj o mnie jak ja pamiętam o Tobie. (Fryderyk Chopin do przyjaciela, 1825) ChopKor1, 47;

Adieu, jeszcze raz całuję was serdecznie (Juliusz Słowacki w liście do matki, 1831) KorSł 13;

Catuje cię serdecznie (Seweryn Goszczyński do przyjaciela, 1833) GoszLis 20;

Catuję Was wszystkich jak najserdeczniej (Seweryn Goszczyński do przyjaciela, 1839) GoszLis 40;

Catuję Cię serdecznie (oficjalista w zakończeniu listu do przyjaciela, 1844) ChrzPam 203;

Catuje Was serdecznie i nieskończenie (szlachcic do rodziny, 1845) WysLis 36.

W niektórych subskrypcjach podkreślano swe przywiązanie do adresata hiperbolizując ilość pocałunków:

Mamo droga, całuję ciebie po tysiąc razy (Juliusz Słowacki, 1833) KorSł 163;

Ściskam cię i potysiąckroć caluję (Stanisław Trentowski do przyjaciela, 1836) TrenLis 4;

Całuję cię przy każdym wierszu tego długiego listu po dwa razy przynajmniej (Narcyza Żmichowska do brata, 1838) ŻmLis1, 90;

Catuję cię stokrotnie (Narcyza Żmichowska do przyjaciółki, 1845) ŻmLis2, 10.

Możliwe było też połączenie tej formuły z innymi aktami pożegnalnymi:

Całuje cię, ściskam, pieszczę za wszystkie siostry (Narcyza Żmichowska do brata, 1838) ŻmLis1, 91;

Tymczasem całuję cię, i dowidzenia (Seweryn Goszczyński do przyjaciela, 1839) GoszLis 69;

Catuję Cię i ściskam serdecznie (Helena Modrzejewska do brata, 1862) KorMod 45.

Znajdujemy też przykłady mocno zindywidualizowanej obudowy etykietalnej:

Droga mamo, całuję ciebie z całej duszy i z całego serca mojego (Juliusz Słowacki, 1834) KorSł 186; 
Caluję cię $\mathrm{z}$ ducha, mój Bracie, całuję cię także w imieniu innych mych braci (Seweryn Goszczyński do znajomego „współbrata” z kręgu Andrzeja Towiańskiego, 1844) GoszLis 182 - określenie ,z ducha” nie jest tu przypadkowe. Często można je spotkać w listach osób z kręgu Koła Sprawy Bożej i zapewne odnosi się ono do towiańskiej idei duchów;

Catuje cię pocałowanie braterskim (Seweryn Goszczyński do znajomego „współbrata” z kręgu Andrzeja Towiańskiego, 1844) GoszLis 184;

Teraz tak was caluje jak mnie nikt w życiu nie pocałował (Narcyza Żmichowska do przyjaciółki, 1845) ŻmLis2, 31.

Takie pożegnanie mogło też być kierowane do osób trzecich - wtedy zamiast zaimka używane są imiona lub nazwy pokrewieństwa:

Babkę i przyjaciół całuję (mieszczanin w liście do brata, 1831) PamL 43;

Marynię i niańkę jej Martę całuję (lekarz w liście do przyjaciółki, 1838) MorLis 35 .

W badanym materiale możemy odnaleźć też subskrypcje, które są połączeniem obydwu typów omawianych tu formuł. Ich schemat wygląda następująco: caluję + zaimek osobowy adresata $+\mathrm{w}+$ biernik nazwy części ciała:

Łasce mnie Twojej oddaję i caluję cię $w$ serce (Jan Śniadecki w liście do przyjaciela, 1791) ŚniaLis 36;

Mamo, całuje Ciebie serdecznie $w$ raczki (Juliusz Słowacki, 1831) KorSł 17 ;

Całuje ciebie $w$ oba oczka twoje, Hersylko (Juliusz Słowacki do krewnej, 1835) KorSł 228;

Ciebie $w$ tysine calujac, zostaję, jak zawsze bratem przywiązanym (Józef Kraszewski do brata, 1853) KraszLis 238.

Akty te stosowano również tylko w relacjach symetrycznych, w prywatnej korespondencji z bliskimi osobami. Wybór części ciała jest tu dużo swobodniejszy niż w przypadku pierwotnego schematu catuję rękę.

\subsection{5. „ściskam...” i przekształcenia}

Ta wyłącznie epistolarna formuła zdobywa dużą popularność w pierwszej połowie XIX wieku, ale znana jest już w drugiej połowie XVIII stulecia. Ściskam łączono zwykle z biernikiem określającym osobę odbiorcy a sposób funkcjonowania tej frazy jest podobny do schematu catuje + biernik zaimka adresata. Akt ten był używany przede wszystkim w korespondencji osób sobie równych: bliskich znajomych, przyjaciół i rodziny - gest uściśnięcia, do którego odwołuje się subskrypcja, wyraża bliskość relacji. Niekiedy znajdujemy ją również w listach osób wyższych rangą pragmatyczną od odbiorcy:

Adieu, ściskam cię serdecznie (Stanisław August Poniatowski do Ksawerego Branickiego, 1768) KonfB 21; 
Dziś kończę serdecznie Ciebie ściskając (Stanisław August Poniatowski do Ksawerego Branickiego, 1768) KonfB 148;

Serdecznie ściskam, etc. ... (kasztelanowa do siostrzeńca, 1781) LisKos 164;

Życząc Ci wszystkiego dobrego, ze serca ściskam (Zygmunt Krasiński do plenipotenta, 1858) KrasLis 258.

Akty te cechuje duże zróżnicowanie formalne. Możliwe było łączenie ich $\mathrm{z}$ innymi typowymi formułami listownymi. Konwencjonalne elementy obudowy etykietalnej to okoliczniki (zwykle serdecznie) oraz formy adresatywne:

Ściskam cię serdecznie, kochana Kuzynko (szlachcianka do krewnej, ok. poł. XVIII w.) TańList 82;

Ściskam serdecznie Kochanego Brata, żonę, dzieci, czeladkę, gospodarstwo cum omni castitate et prudentia [łac. z całą uprzejmością i szacunkiem] (Ignacy Krasicki do brata, 1763) KKor1, 73;

Ściskam serdecznie WMP (Ignacy Krasicki do brata, 1767) KKor1, 183;

Adieu, Ściskam Pana serdecznie (Ignacy Potocki do Grzegorza Piramowicza, 1786) KorPot 146;

Ściskam Cię serdecznie i Twojej mnie łasce oddaję (Jan Śniadecki do przyjaciela, 1791) ŚniaLis 33;

Ściskam serdecznie Pana mego (Jan Śniadecki do przyjaciela, 1793) ŚniaLis 108 ;

Ściskam Cię serdecznie i twojej mnie zawsze przyjaźni polecam (Jan Śniadecki do przyjaciela, 1788) ŚniaLis 8;

Ściskam Cię najserdeczniej, Twój dozgonny przyjaciel i sługa (Michał Ogiński do Ksawerego Brzostowskiego, 1827) WysLis 13;

Ściskam ciebie, kochana mamo, babuniu i dziaduniu, Teofilu, Hersylko etc. (Juliusz Słowacki, 1831) KorSł 31;

Ściskam Was wszystkich serdecznie (mieszczanin do brata, 1831) PamL 38;

Pozdrawiając wszystkich jak najuprzejmiej, ściskam i całuję po tysiąc razy wraz z Tobą, najukochańszy Bracie, którego zostaję dozgonnie szczerożyczliwym i kochającym bratem (mieszczanin do brata, 1832) PamL 40;

Adieu, mój drogi, ściskam Cię serdecznie (siostra do Fryderyka Chopina, 1834) ChopKor1, 245;

Ściskam Cię, mój drogi Frycku, wraz z Antkiem i błogosławię Was obydwóch (Teresa Wodzińska do Fryderyka Chopina, 1836) ChoKor1, 275;

Ściskam Cię najczulej (Teresa Wodzińska do Fryderyka Chopina, 1836) ChoKor1, 290;

Czekam parę słów od Pana i ściskam Go najserdeczniej, najserdeczniej (Fryderyk Chopin do Józefa Elsnera, 1840) ChopKor2, 10;

Ściskam cię, Julku mój (Zygmunt Krasiński do Juliusza Słowackiego, 1841) KraSł 27;

Nie ma nic więcej do napisania, dlatego kończę i ściskam was serdecznie (Seweryn Goszczyński do przyjaciela 1842) GoszLis 143; 
Ściskam cię silnie i gorąco (Zygmunt Krasiński do przyjaciela, 1846) KraMał 110;

Ściskam Was wszystkich, ile jest, a Ciebie jeszcze raz (Józef Kraszewski do brata, 1852) KraszLis 232;

Ściskam cię serdecznie (Teofil Lenartowicz do przyjaciela, 1852) LisLen 39;

Ściskam cię najserdeczniej, Kochany Ewarystku i życzę zdrowia jak najprędszego (Teofil Lenartowicz do przyjaciela, 1855) LisLen 94;

Ściskam Was, Najdroższy Panie Józefie, polecając dobremu Waszemu sercu wszystkie prośby moje (Teofil Lenartowicz do Józefa Kraszewskiego, 1858) LenarKor 52.

Inny często występujący, ale dopiero od XIX wieku, element obudowy etykietalnej, to mniej lub bardziej konwencjonalne wyrażenia okolicznikowe:

Ja Pana mego przy osobnym uszanowaniu z serca ściskam, najniższy sługa (Ignacy Potocki do Tadeusza Czackiego, 1802) KorPot 232;

Ściskam cię, kochany książę, z uczuciem prawdziwej przyjaźni (Tadeusz Kościuszko do Adama Czartoryskiego, 1815) KośWsp 128;

Ściskam Cię z duszy (matka do Fryderyka Chopina, 1837) ChopKor1, 296;

Ściskam Cię jak boa (Fryderyk Chopin do przyjaciela, 1837) ChopKor1, 307 ;

Ja ściskam cię od serca (Wincenty Pol do przyjaciela, 1838) LisPol 30;

Ściskam Was od duszy i oddaję Bogu (Wincenty Pol do przyjaciela, 1840) LisPol 60;

Tymczasem ściskam cię od serca (Seweryn Goszczyński do przyjaciela, 1841) GoszLis 123 ;

Ściskam Cię wraz z czeladzią z całej duszy (Wincenty Pol do żony, 1844) LisPol 124;

Ściskam cię z wszystkich sił serca (Zygmunt Krasiński do przyjaciela, 1846) KrasMał 50;

Ściskam cię z głębi sercowej (Zygmunt Krasiński do przyjaciela, 1846) KrasMał 53;

Ściskam cię z duszy (Zygmunt Krasiński do przyjaciela, 1847) KrasMał 118;

Ściskam Cię z całej duszy (Adam Mickiewicz do przyjaciółki, ok. poł. XIX w.) MicKon 12;

Ściskam cię z całej duszy (Teofil Lenartowicz do przyjaciela, 1852) LisLen 48.

Niekiedy zwiększano solenność formuły hiperbolizując liczbę uścisków:

Ściskam po tysiąc kroć serdecznie (Grzegorz Piramowicz do Ignacego Potockiego, 1784) KorPot 135;

Tymczasem ściskam cię po tysiąc razy (Seweryn Goszczyński do przyjaciela, 1829) GoszLis 10;

Bogu Cię oddaję wraz z dziećmi i ściskam po milion razy (Wincenty Pol do żony, 1841) LisPol 80. 
Inny, rzadko spotykany wariant tej formuły: ściskam + nazwa części ciała, został zapewne utworzony na wzór typu całuję ręce. Czasownik całować może również występować w takich frazach:

Adieu. Ściskam nóżki i całuję. (Józef Szymanowski do starościny wyszogrodzkiej, 1795) SzymLis 80;

Ściskam raczki, nóżki najukochańszego mego Papy (Maurycy Mochnacki, 1832) MochLis 90;

Ściskam Was najserdeczniej, nóżki i rączki Mameczki (Fryderyk Chopin do rodziny, 1846) ChopKor2, 176;

$\mathrm{Z}$ czcią ściskam tę rękę, którą wkrótce uściskać istotnie mam nadzieję (Wincenty Pol do przyjaciela, 1844) LisPol 128;

Ściskam $i$ całuję ręce $i$ stopy wasze (guwernantka w do rodziców poł. XIX w.) DmNa 78.

Uściski przekazywano także osobom trzecim. Człon werbalny mógł mieć wtedy postać rozkaźnika:

Uściśnij wszystkich braci (Adam Mickiewicz do Józefa Jeżowskiego, 1820) KorFil 95;

Ściśnijcie tam ode mnie każdą przyjazną rękę (Narcyza Żmichowska do przyjaciółki, 1847) ŻmLis2, 62;

Uściśnij nogi i ręce Kochanego Ojca, ucałuj rączki żony i pocałuj Sławka i Stasia, a sam przyjm serdeczny uścisk (Józef Kraszewski do brata, 1859) KraszLis 416 - w subskrypcji omawiany akt został wykorzystany dwukrotnie. Ten kierowany do adresata przybiera postać ceremonialnego zwrotu przyjm uścisk. W badanej epistolografii możemy wskazać więcej takich analitycznych, niestandardowych wariantów formuły:

Ja kończę serdecznem uściskaniem (Stanisław August Poniatowski do Ksawerego Branickiego, 1768) KonfB 5;

Kończę serdecznym Pana uściskaniem, z osobnym przywiązaniem i poważaniem zostając Pana najniższy sługa (Ignacy Potocki do Jana Śniadeckiego, 1808) KorPot 237;

Kochanej cioci Zosi zasyłam serdeczne uściśnienie (Maurycy Mochnacki, 1832) MochLis 14;

Od żony mojej proszę przyjąć zapewnienia szacunku - ode mnie serdeczne uściśnienie i życzenia zdrowia dobrego (Wincenty Pol do znajomego, 1838) LisPol 35;

Przyjmij szczere uściśnienie od twojego zawsze Seweryna (Seweryn Goszczyński do przyjaciela, 1841) GoszLis 130;

Przyjmij serdeczne uściśnienia od Twego Chałubińskiego (Tytus Chałubiński do przyjaciela, 1848) ChałLis 38 ;

Załaczam Ci braterskie uściśnienie w Panu Jezusie Chrystusie (zakonnik do zakonnika, 1851) LisDuń 149. 


\subsection{6. „sługą uniżonym”, „,najniższym sługą”, ,podnóżkiem” itp.}

\subsubsection{W rozmowach}

Formuły tego typu w funkcji pożegnania nigdy nie były w polszczyźnie powszechne i prawdopodobnie ich źródłem są obce wzorce ${ }^{28}$. W epoce średniopolskiej miały niską frekwencję i stan ten utrzymuje się również w okresie nowopolskim. Jeśli już się pojawiają, to niemal zawsze ze zredukowanym członem werbalnym - w badanych tekstach jedynie raz pojawia się pełna formuła:

Mam honor zostać uniżonq stuga (szlachcianka do szlachcica, I poł. XIX w.) FrDz1, 383.

Człon nominalny także uległ przekształceniu - narzędnik zostaje zastąpiony mianownikiem:

Uniżona stuga waćpana (szlachcianka do narzeczonego, II poł. XVIII w.) BDr 92;

Stuga uniżony (notariusz do barona, I poł. XIX w.) FrDz2, 274;

Stuga i podnóżek pana hrabiego (szlachic, poł. XIX w.) ŁozDw 296.

Nawet tak szczupły materiał pozwala stwierdzić, że wbrew semantycznym wykładnikom niższości, które w tym pożegnaniu występują, użycie go nie ograniczało się do sytuacji, gdy odbiorca miał wyższą rangę pragmatyczną od odbiorcy. Używane w nim określenia nadawcy stuga, podnóżek prawdopodobnie od początku miały jedynie konwencjonalny charakter.

\subsubsection{W listach}

W epistolografii frazy tego rodzaju bardzo często występowały w subskrypcjach. W dobie średniopolskiej zakres ich użycia zależał od tego jak wyglądał człon werbalny. Do osób o dużo wyższej randze pisano oddaję się, zostawam, piszę się, natomiast dla równych rangą i bliskich przeznaczone były formuly oparte na czasowniku $b y c^{29}$. W badanym okresie podział ten w praktyce epistolarnej zwykle nie jest już przestrzegany. Większość zebranego materiału pochodzi z drugiej połowy XVIII wieku w kolejnym stuleciu najwyraźniej subskrypcje te powoli wychodzą z użycia.

W relacji asymetrycznej, gdy nadawca kierował formułę do osoby o wyższej randze, dopuszczalne były już konstrukcje oparte na być:

Uniżam się do stóp Pańskich wyznając, żem jest Jaśnie Wielmożnego WPana Dobrodzieja obowiązanym i najniższym stuga (Adam Naruszewicz do starosty żmudzkiego, 1773) KorNar 19;

${ }^{28}$ Po raz pierwszy pojawiają się w poradniku wydanym w 1691 r. M. Cybulski, Obyczaje językowe..., s. 78.

${ }^{29}$ Ibidem, s. 73. 
Upadam do nóg najosobliwszego Dobrodzieja mego, oświadczając się, żem do zgonu życia Jaśnie Wielmożnego WPana Najłaskawszego Dobrodzieja najżyczliwszym i najniższym stuga (Adam Naruszewicz do Stanisława Augusta Poniatowskiego, 1775) KorNar 32;

W żywym pragnieniu upadnienia do nóg Łaskawych i trzymania się aż do śmierci podnóżka tronu jestem Waszej Królewskiej Mości Pana mego Miłościwego najniższy sługa i wierny poddany (Adam Naruszewicz do Stanisława Augusta Poniatowskiego, 1776) KorNar 56;

Jestem z najgłębszym respektem JWP Dobrodzieja najniższym stugq (ks. Onufry Kopczyński do Ignacego Potockiego, 1778) KorPot 34;

Jestem z rzetelnym szacunkiem WW Pana Dobrodzieja najniższym stuga (plenipotent do Zygmunta Krasińskiego, 1857) KrasLis 396.

W celu zwiększenia długości i grzeczności subskrypcji niekiedy zastępowano proste jestem honoryfikatywnym zwrotami:

Szczerze wyznaję, żem jest JWWMP Dobrodzieja najniższy podnóżek (korespondent zagraniczny KEN-u do Ignacego Potockiego, 1778) KorPot 38;

Wyznaję się być JW Pana i Dobrodzieja najuniżeńszym i najobowiązańszym stuga (kancelista KEN-u do Ignacego Potockiego, 1779) KorPot 48;

Racz przyjąć, Jaśnie Oświecony Mości Książę, łaskawe oświadczenie najgłębszego uszanowania i podległości, z którą mam honor być Jaśnie Oświeconej Waszej Książęcej Mości najpokorniejszym stuga (August Bécu do Adama Czartoryskiego, 1818) LisRS 32.

Nadal jednak w relacjach asymetrycznych stosowano tradycyjnie dla nich przeznaczone frazy z czasownikami piszę się i zostaję, które również często obudowywano grzecznościowymi zwrotami w rodzaju mam honor:

Oddaję mię łasce i z głębokim piszę się respektem JWWJP Dobrodzieja najniższym sługa (pisarz sądowy KEN-u do Ignacego Potockiego, 1777) KorPot 30;

Prośbę tę naszą i nas samych wielkiej Pańskiej oddawszy protekcji piszemy się JWP Dobrodzieja najniższymi stugami (nauczyciele do Ignacego Potockiego, 1777) KorPot 27;

Losy „Gramatyki” i gramatykę złożyła Opatrzność w najlepszych rękach, które ja całując jestem z najgłębszym respektem JWP Dobrodzieja i Obrońcy najniższym stugq (ks. Onufry Kopczyński do Ignacego Potockiego, 1778) KorPot 35;

Chciej się do poprawy losu mojego przyłożyć, a pewien jestem, że skutek pomyślny odbiorę, za co pisać się będę na zawsze JWMP Dobrodzieja najniższym stuga (ksiądz - nauczyciel do Ignacego Potockiego, 1787) KorPot 160;

Mam sobie za zaszczyt zostawać z winnym uszanowaniem JWWMP Dobrodzieja najniższym stuga (kasjer KEN-u do Ignacego Potockiego, 1777) KorPot 30 ;

Zostaje z najpowinniejszym uszanowaniem JWPana i Dobrodzieja najniższym i najobowiązańszym sługa (prefekt szkoły do Ignacego Potockiego, 1780) KorPot 80; 
Z winnym szacunkiem mam honor zostawać WM Pana Dobrodzieja najniższym sługa (Jan Śniadecki do prymasa Michała Jerzego Poniatowskiego, 1791) ŚniaLis 20;

Z najgłębszym uszanowaniem mam honor zostawać Jaśnie Oświeconej Wksiążęcej Mości Dobrodzieja najniższym sługą (Franciszek Karpiński do księcia Radziwiłła, 1791) KarpKor 43;

Mam honor do zgonu życia zostać najprzywiązańszym sługą (sekretarz do Ignacego Potockiego, 1793) TKor 174;

Zostaję uniżonym stuga (rządca do ziemianina, poł. XIX w.) ŁozDw 329;

Pozostaje w Chrystusie Panu życzliwym jej stuga (zakonnik do hrabiny, 1851) LisDuń 170;

Mam sobie za zaszczyt zostawać Jaśnie Wielmożnego Pana Hrabiego najniższym stuga (plenipotent do Zygmunta Krasińskiego, 1858) KrasLis 370.

Charakterystyczną cechą powyższych aktów jest bardzo bogata obudowa etykietalna. Liczne przymiotniki określające nadawcę nie ograniczają się już tylko do konwencjonalnych uniżony, najniższy. Najczęściej w celu intensyfikacji wprowadzana jest forma superlatywna, co dodatkowo podkreśla dystans między nadawcą a odbiorcą. Czasem samo określenie stuga nie wystarcza i dodawany jest kolejny element np. podnóżek, poddany. Na rozbudowane formy adresatywne składają się tytulatura i formy atrybutywne wskazujące wyższość adresata. Do nowości zaliczyć należy też zwyczaj tworzenia fraz według schematu: czasownik $+\mathrm{z}+$ narzędnik rzeczownika abstrakcyjnego typu: zostaje z szacunkiem. Wydłużanie subskrypcji za pomocą tych wszystkich środków być może miało na celu przywrócenie pospolitującym się formułom ich pierwotnej funkcji wskazywania na wyższość odbiorcy.

O tym, że te ewentualne próby nie były zbyt skuteczne, świadczy postać subskrypcji stosowanych w relacjach symetrycznych oraz gdy pisano do rodziny. Sa one bardzo podobne do tych używanych w sytuacji podrzędno-nadrzędnej. Jedynym wyznacznikiem równości nadawcy i odbiorcy mogą być pewne formy autoadresatywne np. brat ${ }^{30}$, przyjaciel czy nazwy pokrewieństwa:

Jestem z głębokim respektem JWWM Pani Dobrodziejki z serca kochającym synem i najniższym podnóżkiem (Ignacy Krasicki do matki, 1757) KKor 24;

Kochanego Brata serdecznie uściskawszy zostaję z serca kochający brat i najniższy stuga (Ignacy Krasicki, 1760) KKor 38;

Teraz łaskawej mnie Jego oddając protekcji z głębokim zostaję respektem Jaśnie Wielmożnego WMP Dobrodzieja najniższym sługa (Ignacy Krasicki do Franciszka Salezego Potockiego, 1760) KKor 30;

${ }^{30}$ Określenie brat (w przypadku, gdy nie chodzi o relację pokrewieństwa) wskazuje na równość nadawcy i adresata - jest wyrazem solidarności stanowej i szlacheckiej równości. M. Mroczek, 1978, Tytulatura w korespondencji staropolskiej jako problem stosunku między nadawca a odbiorcq, „Pamiętnik Literacki” 1978, z. 69, s. 131. 
Wyznawam się być z serdecznym przywiązaniem i wysokim szacunkiem JWWMWMP Kochanego Dobrodzieja życzliwym bratem, uniżonym stuga (arcybiskup gnieźnieński do Ignacego Potockiego, 1779) KorPot 47;

Jestem z uprzejmym przywiązaniem stuga i przyjaciel (Adam Naruszewicz do królewskiego sekretarza, 1781) NarLis 491;

$\mathrm{Z}$ najmilszym czuciem powiadam, żem jest najobowiązańszym Jego stugq (Grzegorz Piramowicz do Ignacego Potockiego, 1782) KorPot 122;

Ja serdecznie JWMW Pana uściskawszy zostaje z prawdziwym afektem kochającą ciotką i uniżoną stuga (kasztelanowa do marszałka, 1788) LisKos 191;

Zostaje z winnym szacunkiem i przywiązaniem dobry przyjaciel i stuga (Jan Śniadecki do przyjaciela, 1788) ŚniaLis 11;

Mam honor zostawać z powinnem uszanowaniem Jaśnie Wielm. WM Pana Dobrodzieja najniższym sługa (Jan Śniadecki do Hugona Kołłątaja, 1790) ŚniaLis 14;

Zostaję z głębokim szacunkiem najniższą stuga (arystokratka do przyjaciela, lata 40. XIX w.) RusWar4, 158;

Zostaję z najgłębszym uszanowaniem JWM Pana Dobrodzieja najniższym stuga (Euzebiusz Słowacki do Jana Śniadeckiego, 1811) LisRS 20;

$\mathrm{Z}$ największym przywiązaniem jestem WW Pana Dobrodzieja najniższy stuga i podnóżek (znajomy do Franciszka Karpińskiego, 1813) KarpKor 217;

$\mathrm{Z}$ radością chwyciłem zarazem sposobność zapewnienia WPana Dobrodzieja o wysokim szacunku z jakim zostaje prawdziwym i uniżonym stuga (Fryderyk Chopin do znajomego, 1831) ChopKor1, 174.

\subsection{7. ,gostaję z...", ,,jestem z..." itp.}

Frazy typu zostaje (jestem) $z+$ nazwy abstrakcyjne stały się modne w XVIII wieku. Na początku używane głównie przez magnaterię ${ }^{31}$, szybko rozprzestrzeniły się w korespondencji całego szlacheckiego stanu. O ich popularności świadczy fakt, że występują w dużej części formuł omówionych w poprzednim rozdziale, ale ich użycie nie ogranicza się do tamtych aktów.

Kończono w ten sposób listy do wyższych i równych rangą, również do rodziny. Standardowe rzeczowniki obecne w takich subskrypcjach pochodzą z kręgu znaczeniowego szacunek i często poprzedza je przymiotnik zwiększający wartość grzecznościową formuły. W zebranym materiale zdecydowanie rzadziej występują zakończenia z jestem:

Jestem $z$ najgłębszym uszanowaniem i dozgonnym przywiązaniem (Adam Naruszewicz do Adama Czartoryskiego, 1762) KorNar 4;

Jestem $z$ głębokim uszanowaniem i zupełnym szacunkiem obojga Państwa (Adam Naruszewicz do starosty żmudzkiego, 1773) KorNar 8;

${ }^{31}$ M. Cybulski, Obyczaje językowe..., s. 106. 
Jestem $z$ jak najgłębszym upadnieniem przed tronem najlepszego monarchy (Adam Naruszewicz do Stanisława Augusta Poniatowskiego, 1775) KorNar 34;

Jestem $z$ jak najgłębszym respektem i dozgonną wdzięcznością (Adam Naruszewicz do Stanisława Augusta Poniatowskiego, 1793) KorNar 468.

Formuły zawierające zostaje $z$ są używane znacznie powszechniej:

Zostaje z uszanowaniem (Franciszek Karpiński do znajomej, 1777) KarpKor 13;

Zostaję z winnym szacunkiem i przywiazaniem (Jan Śniadecki do znajomego, 1788) ŚniaLis 11;

Zostaje z prawdziwem przywiazaniem (kasztelanowa do marszałka, 1790) LisKos 213;

$Z$ najgłębszym uszanowaniem zostaję na całe życie (Franciszek Karpiński do księcia Radziwiłła, 1792) KarpKor 54;

Zostaję $z$ winnym szacunkiem i konsyderacyja (Jan Śniadecki do znajomego, 1794) ŚniaLis 157 ;

Oddaję mię litości Twojej i przyjaźni, zostając z powinnym uszanowaniem (Elżbieta Sapieżyna do Franciszka Karpińskiego, 1799) KarpKor 99;

Zostaje z najwyższym upoważnieniem (znajoma do Franciszka Karpińskiego, 1803) KarpKor 158;

Ściskając Cię najserdeczniej, Przyjacielu mój, zostaję z winnym szacunkiem (Franciszek Karpiński do przyjaciela, 1818) KarpKor 225;

Prosze przyjąć zapewnienie uwielbienia z jakim na zawsze zostaje pańskim wdzięcznym i przywiązanym uczniem (Fryderyk Chopin do Józefa Elsnera, 1831) ChopKor1, 171;

My na zawsze zachowamy dla Niej uczucie wdzięczności, przywiqzania, szacunku, z którymi zostaję Babuni Dobrodziejki przywiązany wnuk (Józef Kraszewski, 1839) KraszLis 88;

Życząc wam wszystkim Nowego Roku, pozostaję $z$ wysokim szacunkiem (Stanisław Trentowski do przyjaciela, 1842) TrenLis 99;

Zostaje z szacunkiem $i$ poważaniem (uczeń do stryja, lata 40. XIX w.) CieszT1, 186;

Życząc ci Panie, najdłuższego życia i dobrego humoru ku szczęściu spólnej (sic!) matki ojczyzny, pozostaję z głębokim szacunkiem (Stanisław Trentowski do Joachima Lelewela, 1843) TrenLis 109.

Zdarzały się także bardziej ceremonialne warianty takich formuł:

Mam honor być z najgłębszym respektem (kasztelanowa do elektorowej saskiej, 1763) LisKos 46;

Ja mam honor wyznać się z najwyższym uszanowaniem (sekretarz do Ignacego Potockiego, 1792) TKor 83. 


\subsection{8. ,życzę" i przekształcenia}

Rolę pożegnania w epistolarnych subskrypcjach mogły pełnić także akty życzeń. W okresie średniopolskim fraza dobrego zdrowia życzymy była typowym zakończeniem w listach królewskich ${ }^{32}$. W ekscerpowanych tekstach doby nowopolskiej znajdujemy ją dwa razy w listach Stanisława Augusta Poniatowskiego:

Dobrego zdrowia do usługi publicznej, do której chwalebnego sprawowania masz wrodzone przymioty i dostateczną sposobność, potrzebnego Uprzejmości Waszej z serca życzemy (do Ignacego Krasickiego, 1765) KKor 92;

Dobrego przytem zdrowia Uprzejmości Waszej od Boga życzymy (do wojewody, II poł. XVIII w.) ChodźPam 33.

W badanym okresie, mimo poświadczenia takich subskrypcji, najwyraźniej zaczyna się odchodzenie od spetryfikowanej formuły, gdyż w królewskich listach spotykamy też bardziej swobodne jej warianty, które nie zawierają nawet tradycyjnie przysługującego monarsze pluralis maiestaticus:

Kończę, Uprzejmości Waszej dobrego od Boga życzqc zdrowia (król do Ignacego Krasickiego, 1765) KKor 94;

Wszelkich z serca życzę WPanu od Boga pomyślności (król do Szczęsnego Potockiego, 1792) KitPam 540.

Konwencjonalne życzenia zdrowia, pomyślności itp. kończą również listy kierowane do przyjaciół i podwładnych. Przy czym ich obecność w prywatnej korespondencji możemy odnotować dopiero w pierwszej połowie XIX w.:

Życzę pomyślności wszelkiej (Ignacy Krasicki do księdza - podwładnego, 1768) KKor1, 199;

Życzę Pani dobrego zdrowia i wesołości (Adam Mickiewicz do Maryli Wereszczakówny, 1822) KorFil 286;

Wszyscy Panu zasyłamy najprzyjaźniejsze ukłony życzymy świąt dobrych i za listy dziękujemy wszyscy (Salomea Słowacka do Antoniego Odyńca, 1827) LisRS 222;

Nóżki Pani mojej całuję i szczerze życzę, aby kąpiele Starej Russy służyły jej dobrze (lekarz do przyjaciółki, 1839) MorLis 43;

Życzę ci poprawienia zdrowia, swobody, szczęśliwej myśli i wszystkiego, czego serce przyjaciela życzeć może (Teofil Lenartowicz, 1854) LisLen 85;

Życzę Panu jeszcze jak najlepszego zdrowia (Elżbieta Krasińska do plenipotenta, 1855) KraLis 270;

Ściskam cię najserdeczniej Kochany Ewarystku i życzę zdrowia jak najprędszego (Teofil Lenartowicz do przyjaciela, 1855) LisLen 94.

Na podstawie prezentowanych tu subskrypcji można stwierdzić, że standardowa formuła składała się z czasownika performatywnego, adresatywu w celowniku

32 Ibidem, s. 104. 
oraz dopełnienia w genetivie. Zdarzają się jednak także inne konstrukcje, pozbawione performatywu, ale są zdecydowanie rzadsze:

Spodziewam się, że Ci co dzień lepiej, czego Ci wszyscy, cały nasz dom życzy a szczególniej Ja Twój najszczerszy przyjaciel (Fryderyk Chopin, 1826) ChopKor1, 62;

Życzenia tylko szlę Panu zawsze, aby Panu zawsze dobrze było, bo cóż ja więcej mogę? (Salomea Słowacka do Antoniego Odyńca, 1827) LisRS 190;

Życząc wam szczęścia i zdrowia, oddaję mnie sercu Waszemu i szanownej przyjaźni Waszej (Wincenty Pol do kustosza biblioteki, 1841) LisPol 67;

Teraz zaś przyjmij najserdeczniejsze me życzenia (Stanisław Trentowski do wydawcy, 1843) TrenLis 106.

\subsection{9. ,pozdrawiam” i przekształcenia}

Formuły te, choć znane już ze średniopolskich subskrypcji ${ }^{33}$, w praktyce epistolograficznej pojawiały się rzadko. Zwiększenie ich frekwencji przypada dopiero na sam koniec badanego okresu - przede wszystkim lata 40.-50. XIX wieku. Akt ten był kierowany do adresata albo do osób trzecich. Obserwujemy dużą wariantywność formuł. Standardowa fraza zawierała czasownik performatywny. Obudowa tych aktów była zwykle ograniczona do biernikowych i wołaczowych adresatywów oraz modyfikatorów przysłówkowych typu serdecznie. Możliwe było też łączenie pozdrowień z innymi aktami pożegnalnymi:

Pozdrawiam przyjaźnie (generał do generała, 1812) PamWoj 257;

Pozdrawiam serdecznie ciebie i twoją rodzinę (Seweryn Goszczyński do przyjaciela, 1841) GoszLis 1841 ;

Pozdrawiam cię, kochany ziomku, z całego serca (Seweryn Goszczyński do wydawcy, 1843) GoszLis 158;

Pozdrawiam was serdecznie i błogosławię z głębi mej duszy waszej córeczce (Seweryn Goszczyński do przyjaciela, 1842) GoszLis 147;

Pozdrawiam i całuję was wszystkich (szlachcic do przyjaciela, poł. XIX w.) DomL 24;

Pozdrawiam cię i całuję w miłości braterskiej (zakonnik do zakonnika, 1849) LisDuń 30;

Serdecznie pozdrawiam i ręce całuję (Adam Mickiewicz do przyjaciółki, 1853) MicKon 13.

Często jednak czasownik performatywny był zastępowany konstrukcjami analitycznymi:

${ }^{33}$ Ibidem, s. 106. 
Łqczę braterskie pozdrowienia (zakończenie odezwy przywódcy spiskowców do mieszkańców Galicji, I poł. XIX w.) PamGal 92;

Pozdrowienie i uściśnienie bratnie załaczam Ci, Bracie najmilszy i Rodzinie całej (zakonnik do współwyznawcy sekty Towiańskiego ${ }^{34}, 1850$ ) LisDuń 86;

Łacze Wam najczulsze pozdrowienia (zakonnik do współwyznawców sekty Towiańskiego, 1850) LisDuń 86.

Człon werbalny mógł mieć postać rozkaźnika:

Przyjm, kochana Pani Konstancyo, najszczersze moje pozdrowienie (Celina Mickiewiczowa do znajomej, I poł. XIX w.) MicKon 28;

Przyjmij moje braterskie pozdrowienia (Seweryn Goszczyński do przyjaciela, 1839) GoszLis 54;

Przyjm braterskie pozdrowienia od wiernego Józefa (Józef Kraszewski do brata, 1858) KraszLis 399.

Pozdrowienia przeznaczone dla osób trzecich również cechowała duża chwiejność formalna:

Wszystkich z WPanem jadących pozdrawiam (Stanisław August Poniatowski do Ksawerego Branickiego, 1768) KonfB 12;

Dziaduniowi posytam pełne uszanowania wnukowe pozdrowienie (Juliusz Słowacki do rodziny, 1834) KorSł 215;

Szanownego Józefa pozdrawiam najuprzejmiej (Seweryn Goszczyński do przyjaciela, 1838) GoszLis 24;

W sam dzień Nowego Roku pozdrawiam cię, Bibianno, tym, co najdroższym zdawać mi się może: serdecznym uściskiem Pauliny (Narcyza Żmichowska do przyjaciółki, 1843) ŻmLis2, 9;

Matkę Makrynę w Panu Jezusie pozdrawiam (zakonnik w liście do współbrata, 1848) LisDuń 3;

Wegnera pozdrów odemnie po bratersku (Teofil Lenartowicz, 1852) LisLen 49.

\subsubsection{0. „polecam się/mię", ,oddaję mnie"}

Formuły typu zalecam się, zalecam stużby, oddaję się w taskę itp. zdecydowanie dominowały w subskrypcjach epistolografii średniopolskiej ${ }^{35}$. W początkach okresu nowopolskiego ich frekwencja wyraźnie spada, a dodatkowo gwałtownie zmniejsza się wariantywność tych aktów. Z całego bogactwa dawnych formuł zostają w użyciu tylko dwa schematy, które swoją postacią nawiązują do tych średniopolskich. Akty te cechuje duża stabilność: w badanych subskrypcjach czasownik niemal zawsze ma formę 1. osoby. Najczęściej oddawano się łasce -

\footnotetext{
${ }^{34}$ Stąd adresatyw bracie.

${ }^{35}$ M. Cybulski, Obyczaje językowe..., s. 79-104.
} 
człon nominalny w dużej mierze również był spetryfikowany. Większą swobodę $\mathrm{w}$ doborze dopełnienia obserwujemy w przypadku fraz z czasownikiem polecać się, gdzie nieraz pojawia się więcej niż jeden rzeczownik oraz epitety. Czasami stosowano szyk przestawny. Akty te bywały również łączone z innymi formułami werbalnymi właściwymi dla finalnych partii listu. Ich zasięg społeczny ograniczał się głównie do środowiska szlachty i arystokracji. Choć zawierały w sobie wykładniki wyższości odbiorcy, to dominują użycia w sytuacji, gdy nadawca i adresat mieli podobne rangi pragmatyczne:

Statecznej polecam mię łasce będąc z winnym uszanowaniem (Ignacy Krasicki do Jana Klemensa Branickiego, 1771) KKor1, 209;

Łasce mnie Twojej oddaję i całuję cię w serce (Jan Śniadecki do przyjaciela, 1781) ŚniaLis 36;

Oddaję mnie do nieustającej łaski WKsMci Dobr. z serca przywiązany a znajomy sługa (brat do Ignacego Krasickiego, 1782) KKor2, 110;

Oddaję mnie łasce (brat do Ignacego Krasickiego, 1782) KKor2,105;

Polecam się nieskończonej Twojej łasce czy przyjaźni, bo to za jedno biorę (Franciszek Karpiński do znajomego profesora, 1787) KarpKor 31;

Polecam mnie twojej łasce i przyjaźni, zostając z winnym szacunkiem i poważaniem WM Pana Dobrodzieja (Jan Śniadecki do znajomego, 1791) ŚniaLis 23;

Polecam mię stałej przyjaźni (Józef Wasilewski do Józefa Wybickiego, 1799) BielBon1, 67;

Mnie samego Jego wieczyście polecam łasce (Stanisław Trembecki do pułkownika, 1802) TremNie 240;

Polecam się jego dobrej przyjaźni (Maria Puttkamerowa do Tomasza Zana, 1823) KorFil 399;

Zatem polecam się łaskom JW Pana Dobr. (Fryderyk Chopin do znajomego, 1825) ChopKor1, 57;

Polecam się pamięci (Joachim Lelewel do znajomego, 1832) LeLNie 41;

Polecam się wzajemnemu sercu (Joachim Lelewel do znajomego, 1832) LeLNie 28;

Łasce i pamięci polecam się jako najuniżeńszy i wierny sługa (lekarz do przyjaciółki, 1838) MorLis 41;

Ściskam Pana Dobrodzieja i polecam mię Jego łaskawemu sercu (Wincenty Pol do znajomego, 1838) LisPol 31;

Polecam siebie życzliwości i Szacownej przyjaźni (Wincenty Pol, 1843) LisPol 107;

Miłości waszej i modlitwie polecam się (zakonnik do współbraci, 1849) LisDuń 20;

Ściskam Cię serdecznie, mój kochany Lucjanie i polecam się Twojej pamięci i braterskiemu sercu (Józef Kraszewski do brata, 1853) KraszLis 236.

Przykłady użycia, gdy status nadawcy był niższy od adresata, są rzadkie i ograniczone do osiemnastego wieku: 
Oddaję mię nieodmiennej łasce, opiece i protekcji Jaśnie Wielmożnego WPana (Adam Naruszewicz do Michała Hieronima Radziwiłła, 1775) KorNar 28;

Łasce mię oddaje JWWMP Dobrodzieja najniższy sługa (pisarz sądowy KEN-u do Ignacego Potockiego, 1777) KorPot 24;

Tymczasem oddają mię łasce i protekcji Pańskiej oświadczam się, żem jest z najgłębszym uszanowaniem Jaśnie Oświeconego WKsżęcej Mości Pana i Dobrodzieja najniższym sługą (Adam Naruszewicz do Michała Hieronima Radziwiłła, 1791) KorNar 385.

Zdecydowana przewaga użyć takich subskrypcji $\mathrm{w}$ relacji symetrycznej świadczy o ich spospolitowaniu się. W badanym materiale odnajdujemy nawet przykład podobnej formuły skierowanej przez Zygmunta Krasińskiego do swojego plenipotenta:

Polecam się zatem Pańskiej opiece i troskliwości (1853, KrasLis 33).

Jest to jednak wyjątek, gdyż wykładniki wyższości zawarte w tego rodzaju formułach były najwyraźniej zbyt silne, by używanie takich aktów rozciagnąć na sytuacje, gdy nadawca stał wyżej w hierarchii społecznej od adresata. Nawet w przytoczonej subskrypcji z listu Krasińskiego standardowa łaska została zastąpiona rzeczownikami w mniejszym stopniu wskazującymi na niższość nadawcy.

\subsection{FORMY „DO ZOBACZENIA”, „DO WIDZENIA (SIĘ)” ITP.}

Formuła ta znalazła się poza przyjętą klasyfikacja, ponieważ trudno w jej przypadku określić z jakiej frazy werbalnej się wywodzi ${ }^{36}$. Te powszechnie dziś używane akty pożegnalne w epoce średniopolskiej były bardzo rzadkie ${ }^{37}$. Ich popularność najwyraźniej przyszła dopiero wraz z dobą nowopolską. Pierwotnie formuła miała postać do ujrzenia. Być może jest to kalka jakiegoś obcojęzycznego pożegnania np. francuskiego au revoir. W zebranym materiale występują trzy schematy: do widzenia (sie), do zobaczenia, do obaczenia. Wariant do ujrzenia najwyraźniej zanika wcześniej, bo nie ma po nim żadnego śladu w ekscerpowanych tekstach. W odpowiedzi na takie pożegnania zwykle powtarzano formułę lub ewentualnie wybierano inny jej wariant:

- Do zobaczenia!

- Do widzenia! (znajome ziemianki na zakończenie krótkiej rozmowy na ulicy, poł. XIX w.) WilkWsp 124.

Możliwa była jednak także odpowiedź za pomocą zupełnie innego aktu oraz łączenie omawianych fraz z drugim standardowym pożegnaniem:

- Do zobaczenia, sługa uniżona.

- Kłaniam. (szlachcianka do znajomego, II poł. XVIII w.) ZabDz1, 177.

${ }^{36}$ M. Cybulski (Obyczaje językowe...) pisze, że możliwe, iż istniała formuła o genezie religijnej w rodzaju: Boże daj ci zdrowie do ujrzenia, ale w żadnym średniopolskim tekście takowej nie znalazł.

${ }^{37}$ Ibidem, s.110. 
Akty te wyróżniają się spośród innych formuł kończących konwersację tym, że są jednocześnie zapowiedzią ponownego kontaktu ${ }^{38}$. Dziś utraciły swoją pierwotną semantykę na rzecz wyrażania funkcji grzecznościowej, uległy leksykalizacji, ale w badanych tekstach obserwujemy jeszcze frazy, w których pojawia się miejsce lub czas kolejnego spotkania, co świadczy o ich literalnym rozumieniu ${ }^{39}$ :

Do widzenia w Karlinie (szlachcic do przyjaciela, poł. XIX w.) KraszDwa 133;

Spodziewam się, że do widzenia w Warszawie (szlachcic do guwernera, poł. XIX w.) KraszH 236;

Do widzenia się tedy, panie hrabio, do widzenia się za trzy miesiące (lichwiarz do hrabiego, I poł. XIX w.) ŁozHis 81;

A zatem do widzenia jutro (szlachcic do znajomego, poł. XIX w.) ŁozDw 167; Do widzenia jutro (szlachcic do znajomej, poł. XIX w.) WilkWsp 134.

\subsubsection{W rozmowach}

Pożegnanie to miało neutralny charakter, gdyż nie zawierało żadnych wykładników sytuacji nadawczo-odbiorczej. Jedynie elementy obudowy etykietalnej w postaci form adresatywnych mogły wskazywać na status odbiorcy. W badanym okresie akty te są często stosowane na zakończenie rozmów zarówno szlachty, jak i mieszczan:

Do zobaczenia (piwowar do dziewczyny, II poł. XVIII w.) BDr 198;

Do zobaczenia, buziaczku (doktor do swojej służącej, II poł. XVIII w.) ZabDz1, 263;

Do obaczenia się (wódz wojsk do szlachcica, II poł. XVIII w.) RzewLis2, 189;

Do zobaczenia, mości majorze (ksiądz do majora, poł. XVIII w.) RzewMich 71;

Do widzenia, do widzenia (kuzynka do kuzyna, pocz. XIX w.) WójSp 201; (szlachcic do szlachcica, poł. XIX w.) ŁozDw 276;

Do widzenia panie kapitanie (starościna do kapitana, pocz. XIX w.) WójN 24;

Do widzenia pułkowniku! (szambelanowa, I poł. XIX w.) KorzWd 38;

Do widzenia się, panie Karosz (szewc do poety, I poł. XIX w.) DzierzS 115;

Do widzenia się Leonie (szlachcianka do narzeczonego, lata 40. XIX w.) DzierzS2, 150;

Do widzenia, koledzy (uczeń, poł. XIX w.) ŁozDw 103;

A teraz do widzenia się, kochany panie (dziedzic do rządcy, poł. XIX w.) ŁozDw 163;

${ }^{38}$ M. Marcjanik, W kręgu grzeczności. Wybór prac z zakresu polskiej etykiety językowej, Kielce 2001, s. 168-169.

39 E. Umińska-Tytoń, Polszczyzna...s. 170-171. 
Do widzenia zatem, panie Gągolewski (rządca do sędziego, poł. XIX w.) ŁozDw 242.

Zaprezentowany materiał pokazuje, że w badanym okresie stopień utrwalenia językowego szablonu jest już wysoki. Tylko raz odnajdujemy żartobliwe przekształcenie formuły:

Do zobaczyska (lokaj do żołnierza, I poł. XIX w.) KorzSt, 73.

\subsubsection{W listach}

Te, jak mogłoby się wydawać, typowo ustne pożegnania w pierwszej połowie XIX w. zaczęły być stosowane w roli listownych subskrypcji. Jedynie w pojedynczych użyciach widać związek z dosłownym znaczeniem:

Do zobaczenia najpóźniej na początku oktobra (Delfina Potocka do Fryderyka Chopina, 1849) ChopKor2, 307;

Może Bóg da do rychłego zobaczenia (Józef Kraszewski do ojca, 1852) KraszLis 225;

Daj mi się choć słowem Cię uściskać i daj Boże do widzenia (Józef Kraszewski do Teofila Lenartowicza, 1858) LenarKor 28.

W pozostałych formułach końcowych element znaczeniowy uległ już zatarciu.

Nieformalność tych aktów zapewne zadecydowała o tym, że używano ich tylko w listach kierowanych do rodziny i przyjaciół. Czasami formuła typu $d o$ widzenia jest tylko jednym z pożegnań zastosowanych w subskrypcji:

Do widzenia się - niech Panu będzie dobrze (Salomea Słowacka do Antoniego Odyńca, 1827) LisRS 206;

Kocham Cię i przyciskam do serca. Do obaczenia, droga Ty (Zygmunt Krasiński do Delfiny Potockiej, 1841) KrasDel 110;

Do widzenia. Ściskam cię słowem i pismem, nim cię uścisnę rękoma. (Zygmunt Krasiński do przyjaciela, 1842) KrasMał 26.

Często jednak taka fraza samodzielnie tworzy finalną partię listu:

Do widzenia, moi najmilsi (Juliusz Słowacki do rodziny, 1835) KorSł 238;

Do widzenia. Do widzenia (Narcyza Żmichowska do brata, 1838) ŻmLis1, 70;

Tymczasem do widzenia (Seweryn Goszczyński do przyjaciela, 1839) GoszLis 66;

Do obaczenia, droga (Zygmunt Krasiński do Delfiny Potockiej, 1840) KraDel 32;

Do zobaczenia (Zygmunt Krasiński do przyjaciela, 1841) KraMał 3;

Do obaczenia (Zygmunt Krasiński do przyjaciela, 1844) KraMał 32;

Do widzenia (Fryderyk Chopin do przyjaciela, 1845) ChopKor 133. 


\subsection{UWAGI KOŃCOWE}

Okres nowopolski przynosi ważne zmiany w etykietalnych aktach pożegnalnych. Wśród formuł konwersacyjnych szerzą się te, które nie wskazują na pozycję społeczną rozmówców i są używane we wszystkich środowiskach: badź zdrów, dobranoc. Prawdopodobnie stąd też popularność nowych fraz: do widzenia, do zobaczenia. Z kolei pożegnania ustne, które wskazywały na niższość nadawcy wypowiedzi w rodzaju upadam do nóg, spospolitowały się i w początkach doby nowopolskiej są powszechnie używane przez równych rangą rozmówców. Formuły o pierwotnie ceremonialnym charakterze typu żegnam, kłaniam tracą swoją odświętność i zaczynają być stosowane na co dzień.

W epistolografii widoczna staje się tendencja do upraszczania zasad rządzących używaniem konkretnych formuł finalnych. Epokę średniopolską cechowało drobiazgowe rozróżnianie pozycji społecznej piszących, natomiast w dobie nowopolskiej stare reguły są coraz częściej łamane. Nawet w korespondencji królewskiej widać większą swobodę. Formuły niegdyś zarezerwowane dla najwyższych stanów rozprzestrzeniają się w listach osób z niższych warstw społecznych, a tym samym ich wartość grzecznościowa spada. W korespondencji prywatnej popularność zdobywają nowe akty typu: ściskam, całuję cię, które odwołują się do nazw gestów typowych w relacji z bliskimi osobami. 


\section{PROŚBY}

Przyjęto tu kryterium autorytetu, a więc zasadę, że ,prośba zachodzi wówczas, gdy osoba o pozycji niższej (realnie bądź pragmatycznie) oczekuje wykonania czynności od osoby dominującej, natomiast z rozkazem mamy do czynienia wtedy, gdy sytuacja jest odwrotna, to jest gdy nadawca z wyższej pozycji zwraca się do niżej usytuowanego odbiorcy "'. Oczywiście został wzięty pod uwagę fakt, że są sytuacje, gdy nadawca jest realnie równy odbiorcy, ale mimo to zwyczajowo gra pragmatyczną rolę niższego ${ }^{2}$, bo tego wymaga sytuacja, w której dochodzi do aktu prośby.

Klasyfikacja jest tu taka sama jak klasyfikacja rozkazów (zob. 4.). Formy wyrażania prośby zostały uszeregowane od najprostszych do najbardziej skomplikowanych.

\subsection{CZASOWNIKI PERLOKUCYJNE 3}

\subsubsection{Tryb rozkazujący czasownika perlokucyjnego}

Najprostszym wykładnikiem prośby była 2 . osoba trybu rozkazującego czasownika, który sygnalizuje akt perlokucyjny wypowiedzi. Formie rozkaźnika towarzyszył adresatyw wokatywny lub niewokatywny (z 3. osobą czasownika), który prawdopodobnie był konieczny w XVIII wieku, a później nie był już wymagany.

\subsubsection{W listach}

Ten najmniej wyszukany sposób formułowania prośby stosowano zarówno w relacjach symetrycznych, jak i wówczas, gdy nadawcę i odbiorcę dzieliła różnica rang pragmatycznych:

J. Wielmożny Wodzu, [...] uwolnij mnie jeszcze od służby we własnym regimencie (hrabia do hetmana, ok. 1775) KraszAu 55;

Uczyń tak, Panie Dobrodzieju (Adam Naruszewicz do starosty żmudzkiego, 1775) KorNar 51;

Mój jenerale, [...] przyślijcie mi posiłki (pułkownik do generała, 1812) PamWoj 236;

${ }^{1}$ M. Cybulski, Obyczaje językowe dawnych Polaków. Formuly werbalne w dobie średniopolskiej, Łódź 2003, s. 114.

${ }^{2}$ E. Goffman, Człowiek w teatrze życia codziennego, Warszawa 2000, s. 276-279.

${ }^{3}$ Pod pojęciem czasownika perlokucyjnego rozumiem czasownik, którego odniesieniem jest akcja będąca zakładanym efektem (aktem perlokucyjnym) prośby np. dla „daj” - to, że ktoś coś daje. 
Niech Pan do nas pisze dużo (Salomea Słowacka do Antoniego Odyńca, 1826) LisRS 153;

Jak najprędzej odpisuj! (Adam Mickiewicz do przyjaciela, 1820) KorFil 164;

Pisz mi często (Juliusz Słowacki do matki, 1833) KorSł 127;

Dialy, módl się za mnie, módl się za mnie (Zygmunt Krasiński do Delfiny Potockiej, 1840) KrasDel 94;

Pozwólcie się wyszumieć mojemu chrzestnemu synowi (lekarz do przyjaciół, 1841) MorLis 50;

Niech mi Papa odpisze rychło (Józef Kraszewski do ojca, 1845) KraszLis 128. liczne:

Przykłady rozkaźnika z obudową honoryfikatywną lub ekspresywną są nie-

Napisz mi z łaski swojej (profesor do znajomego, 1791) ŚniaLis 30;

Rubelki moje niech Pani łaskawie u siebie zatrzyma (lekarz do przyjaciółki, 1838) MorLis 34;

Na Boga, kochany Papo, przysyłaj mi świadectwo, bo zwariuję (Józef Kraszewski do ojca, 1845) KraszLis 129.

\subsubsection{W rozmowach}

W żywej mowie forma adresatywna nie musiała towarzyszyć rozkaźnikowi w przypadku, gdy odbiorca był równy lub niższy rangą od nadawcy:

Kopcie no dalej (garncarz do chłopa, poł. XIX w.) KraszJer 196;

Pomóż mi! (do przyjaciela, poł. XIX w.) KraszDwa 394.

Zwykle jednak formom imperatywnym towarzyszyły zwroty do odbiorcy, które zwiększały poziom honoryfikatywności takich próśb:

Niech wielmożny pan tu na mnie czeka (gajowy do szlachcica, II poł. XVIII w.) RzewLis 92;

Najjaśniejszy panie [...] przyjmij sto tysięcy czerwonych złotych od obywatela (Stanisław Małachowski do króla, kon. XVIII w.) KarpHis 141;

Wracaj pan do mnie (generał do hrabiego, 1794) SchSt 134;

Niech Pan mię uczy, niech mną kieruje! (szlachcianka do szlachcica, pocz. XIX w.) PamFel1, 57;

Idź pan sobie, idź! (chłopka do pana, lata 40. XIX w.) KraszU 59;

Panie, daj nam choć pół ćwiertni żyta, bo z głodu pomrzemy (chłopi do pana, poł. XIX w.) ŻmLis 66;

Przeczytaj pan! (szlachcianka do szlachcica, poł. XIX w.) CieszT2, 42;

Czekaj pan tu chwilkę! (arystokratka do hrabiego, poł XIX w.) KraszH 66;

Niech pani będzie spokojna (lekarz do hrabiny, poł. XIX w.) KraszDz 23;

Niech mnie ojciec postucha (córka, poł. XIX w.) KraszH 36;

Niech wielmożny pan stucha (karczmarz do szlachcica, poł. XIX w.) ŁozDw 311; 
Nie frasujcie się, matuniu (ubogi mieszczanin, po 1860) KraszSt 15.

Często spotykaną obudową etykietalną w rozmowach szlachty było wyrażenie z laski swojej:

Panie Michale, pofatyguj się z łaski swojej do tego huczka (II poł. XVIII w.) ChodźPam 13;

Niech pani z łaski swojej czyta dalej (pocz. XIX w.) PamFel1, 282;

Każ, z łaski swojej, zawołać Balbinę (poł. XIX w.) BujSt 175.

Inne sposoby intensyfikacji prośby używane były także w niższych warstwach społecznych:

Ale przez litość, powiedz, wytłomacz, co się dzieje? (studenci, 1831) LewPam 38;

Feluniu, przez litość zobacz, czy mi się girlanda na głowie nie przekrzywiła? (mieszczki, poł. XIX w.) ŻmPow2, 10;

Nie płacz pani, na Boga (lekarz do szlachcianki, poł. XIX w.) KraszJary 67;

Ale, na miłość Boża, nie zdradźcie mnie (chłopka do mieszczanina, poł. XIX w.) KraszDz 203;

Adyć, przez Boga, cicho bądźcie, moi panowie! (mieszczanie, poł. XIX w.) ŻmPow1, 260.

\subsubsection{Tryb przypuszczający czasownika perlokucyjnego}

Tryb przypuszczający czasownika nazywającego akt perlokucyjny to rzadka i wyszukana forma prośby, występująca w członach podrzędnych zdań złożonych. $Z$ badanych tekstów wynika, że jej użycie było ograniczone do środowiska szlachty.

\subsubsection{W liście}

Gdybyś JWPan Dobrodziej chciał być tak łaskaw przełożyć to komisarzom [...], dogodziłbyś tem dobroczynności swego serca (Jan Śniadecki do Hugona Kołłątaja, 1791) ŚniaLis 13.

\subsubsection{W rozmowach}

Podobnie wyglądało to w salonowej konwersacji:

Gdybyś raczyła kilka jeszcze nic nie znaczacych przydać drobnostek, byłabym ci bardzo wdzięczna (szlachcianka do szlachcianki, poł. XIX w.) ŻmPow2, 15;

Będę najszczęśliwszy z ludzi, jeżeli pani przyjąć raczysz urząd gospodyni (na balu, poł. XIX w.) BujSt 106. 
Natomiast w rozmowach swobodnych skracano taką wypowiedź, pozostawiając tylko zdanie podrzędne, które samo pełniło funkcję prośby:

Może byś więc pan raczyt wystuchać mnie senatis arbitris (szlachta, II poł. XVIIII w.) ChodźPam 14;

Chciałbym kilka słów z jasnym panem pomówić na osobności (kozak do szlachcica, poł. XIX w.) ŁozDw 272.

\subsubsection{Tryb przypuszczający lub czas przyszły czasownika w zda- niu pytajnym}

Dziś typowy, a w epoce średniopolskiej nieistniejący sposób proszenia pytaniem $^{4}$ widać dopiero $w$ tekstach dziewiętnastowiecznych. Charakterystyczna jest obecność zanegowanej formy trybu przypuszczającego lub futurum w większości przykładów. Czasownik jest tu zazwyczaj perlokucyjny, choć zdarza się też orzeczenie modalne ze słowem prosić (typ czy nie mógłbym prosić?).

\subsubsection{W listach}

Nie jest to jeszcze zjawisko częste w epistolografii i ograniczone do korespondencji kierowanej do przyjaciół:

Czy mógłby mi Pan najać ze dwa pokoiki blisko tych wód? (Salomea Słowacka do Antoniego Odyńca, 1827) LisRS 191;

Jeżeli macie drogi porozumienia się ze swoimi rodzinami, czy i ja nie mógtbym z nich skorzystać? (Seweryn Goszczyński do przyjaciela, 1838) GoszLis 23;

Czy by Pan łaskawy po dawnej znajomości a niedawnym sąsiedztwie nie byt tyle dobry i nie pozwolit mi przyjść do siebie jutro o jakiej bądź godzinie? (Klementyna z Tańskich Hoffmanowa do Fryderyka Chopina, 1844) ChopKor2, 124.

\subsubsection{W rozmowach}

Znacznie częściej stosowano pytania w żywej mowie zarówno w relacjach symetrycznych, jak i asymetrycznych. Przykłady z trybem przypuszczającym:

Czy nie wolno by mi było prosić p. kapitana o jaki żołnierski płaszcz, bo nie mam nic (ułan, I poł. XIX w.) PamUł 43;

${ }^{4}$ M. Marcjanik, Polska grzeczność językowa, Kielce 2000, s. 161. oraz M. Cybulski, Obyczaje językowe..., s. 139. 
Proszę cię, czy nie ułatwitbyś mi interesu (hrabia do szlachcica, I poł. XIX w.) WójP 77;

Czy nie można by to odtożyć (mieszczanin do adwokata, I poł. XIX w.) DzierzS 13;

Czy byś pan nie był łaskaw nam wythumaczyć? (baron do geometry, lata 40 . XIX w.) KuWar3, 68;

Czy nie mógtbym prosić o pozwolenie zapalenia cygara (do dam, lata 40. XIX w.) KuWar2, 123;

Nie byłbyś tak grzeczny powiedzieć mi, czy nie obserwowałeś podróżnego? (hrabia do mieszczanina, poł. XIX w.) KraszDz 164;

Czy nie przyjatbyś go do siebie, mój Trzebisiu? (szlachcic do leśniczego, poł. XIX w.) CieszP 35.

Przykłady z futurum:

Drogi ojcze [...] czy nie raczysz nam wyjaśnić te wielką tajemnicę? (szlachcianka, lata 30. XIX w.) RaRa 64;

Czy raczysz mię przyjąc za kuma? (szlachcic, lata 40. XIX w.) PrusMor 117.

\subsection{4. ,racz" "+ infinitivus czasownika perlokucyjnego}

Orzeczenie modalne $\mathrm{z}$ honoryfikatywnym czasownikiem raczyć pojawiało się w całym badanym okresie, częściej jednak w XVIII wieku niż później. Czasownik ten występował w 1. lub. 3 osobie, zależnie od formy adresatywnej, wyrażał oficjalność lub szacunek.

\subsubsection{W listach}

W korespondencji formuły te stosowano, zwracając się zarówno do osób o wyższej randze, jak i w relacjach symetrycznych:

Racz JO. książę zastanowić wielkie moje refleksye (hetman do prymasa, 1763) PamKasz 122;

Racz WKMć dla mnie i dla niego przysłać mi patent na pułk (Ksawery Branicki do króla, 1768) KonfB 17;

Racz JMPan Dobrodziej rozkazać zaległość od 400 m. wypłacić (Jan Śniadecki do Hugona Kołłątaja, 1791) ŚniaLis 19;

Pułkowniku Dobrodzieju mój, do wielu łask racz mi przydać jeszcze jedną (Stanisław Trembecki do pułkownika, 1802) TremNie 240;

Niech się Pan do mnie dziś pofatygować nie raczy (Stanisław Trembecki do pułkownika, 1802) TremNie 241;

Oto są moje myśli, które racz JWPan Dobrodziej rozważyć (Euzebiusz Słowacki do Jana Śniadeckiego, 1811) LisRS 20; 
Racz, czcigodna Pani, wziać pióra do ręki na małą chwilkę (Stanisław Trentowski do Klementyny z Tańskich Hoffmanowej, 1841) TrenLis 55;

Racz udać się do profesora Poplińskiego (Stanisław Trentowski do znajomego, 1842) TrenLis 99;

Racz, kochana Mamo, błogosławić zawsze kochającego i posłusznego syna (szlachcic, 1855) WysLis 73;

Jeszcze prośba jedna! Racz po wyjściu egzemplarza rozesłać (do znajomej, 1856) WilkWsp 141.

\subsubsection{W rozmowach}

Prawie wszystkie przykłady użycia omawianych aktów pochodzą z wypowiedzi w sytuacjach dość ceremonialnych, a nawet oficjalnych. Zwracano się w ten sposób do osób o wyższej lub równej randze pragmatycznej:

Wojski, dobrodzieju, racz nam także nie odmawiać swej łaski i fatygi, a zasiaść w tym kompromisie ze strony naszej (wojewoda podczas posiedzenia, II poł. XVIII w.) ChodźKon 77;

Niech Książę raczy mówić z obywatelami (sędzia, II poł. XVIII w.) KoźPam1, 113;

Niech pan raczy przeczytać ten listek (sługa do szlachcica, II poł. XVIII w.) ZabDz1, 258;

Racz się WaćPan dobrodziej prośbom mym nakłonić (prośba o rękę córki, 1790) NiemPowr 75;

Ach pani racz się za mną do córki twej wstawić (narzeczony, 1823) NiemPod 63;

Raczcie pozwolić, abym i dziś wystapił z mową pogrzebową (student do żałobników, lata 20. XIX w.) PawEd 29;

Racz jaśnie wielmożny pan przyjąć teraz ode mnie rewers na tę sumę (komornik do hrabiego, I poł. XIX w.) KorzKom 44;

Racz mi szanowny pan [...] odpowiedzieć szczerze (mieszczanie, poł. XIX w.) KraszDz 260;

Racz mi powiedzieć, jakiego doznałaś pani wrażenia po przeczytaniu tej powieści? (szlachcic do szlachcianki, poł. XIX w.) DmNa 93;

Racz mnie pani wytlumaczyć przed panem Augustem, że oddalę się pierwej (na przyjęciu u P. Wilkońskiej, poł. XIX w.) WilkWsp 134.

\subsection{5. „raczysz”+ infinitivus czasownika perlokucyjnego}

Konstrukcje z formą czasu przyszłego raczysz jako wykładnik prośby to cecha języka głównie XVIII wieku. Formę tę, mimo że zapewne wywodzi się z rozkaźnika racz, w kontekście próśb interpretować należy jako należącą do paradyg- 
matu futurum, podobnie jak np. synonimiczne (i rzadsze) pozwolisz i in. O tym, że są to formy czasu przyszłego świadczy również fakt, że w wielu przykładach owo raczysz wchodzi w skład zdań złożonych, w których paralelne zdania mają niewatpliwe futurum orzeczenia, np. zważysz i raczysz.

\subsubsection{W listach}

Prawie wszystkie znalezione przykłady pochodzą z epistolografii. Pisano w ten sposób przede wszystkim do osób o wyższej randze:

Raczysz mi dać radę, co mam sobie postąpić (komendant Kamieńca do hetmana, 1764) RzewKron 52;

Zważysz tedy JWPan i raczysz WKMośc z tego listu wypisać treść moich dyspozycji (Ksawery Branicki do króla, 1768) KonfB 9;

Raczysz mnie zaraz ostrzec (Jan Śniadecki do przyjaciela, 1791) ŚniaLis 31;

Wasza Ks. Mość jako bliski Janusza nauczyć mię raczysz, czyli nie byłoby daremnym powtórzenie prośby (Stanisław Trembecki do księcia, 1801) TremNie 222;

Raczysz, Jaśnie Wielmożny Panie, powziqć łaskawie wiadomość i przekonanie z wyjaśnienia, które poważamy się tu załączyć (szlachcic do hrabiego, 1859) KrasLis 356.

\subsubsection{W rozmowach}

Użycie w ozdobnej konwersacji trafiało się dopiero w połowie XIX wieku:

Panna Natalia raczy darować, że poproszę jej na chwilę zostawić nas samych (znajomy do modystki, lata 40. XIX w.) KuWar2, 154;

Pan dobrodziej raczy mi dać list do siebie (sędzia do szlachcica, poł. XIX w.) ŁozDw 359.

Wyraźny jest tutaj wpływ etykiety epistolarnej na konwersacyjną.

\subsection{6. „chciej”+ infinitivus czasownika perlokucyjnego}

Słowo, synonimiczne niegdyś wobec raczyć, było od niego rzadziej używane, ale również przez cały czas objęty eksploracją. W kontekście trzecioosobowym (np. niekiedy przy pan, pani itd.) występował odpowiednik dokonany zechcieć.

\subsubsection{W listach}

W badanej korespondencji omawiane tu formuly występują zwykle w sytuacji, gdy nadawca pisze do adresata o wyższej randze pragmatycznej. Konteksty są przeważnie oficjalne: 
Chciej tę łaskę, o którą proszę, z najpierwsza zrównać cnotą miłosierdzia (żona do Karola Radziwiłła, 1773) KorRadz 91;

Chciej W.K.M. destynować dla tego godnego kapłana i uczonego obywatela (Adam Naruszewicz do króla, 1776) NarLis 479;

Chciej się WPan z nim rozmówić (Hugo Kołłątaj do barona, 1782) KołLis1, 8;

Chciejcie mnie powrócić do Litwy (Tadeusz Kościuszko do zwierzchnika, 1790) KośWsp 12;

Chciej Pan to zrobić w osobnym artykule (literat do hrabiego, 1842) KorGrab2, 59.

Zdecydowanie rzadziej stosowano takie akty grzecznościowe w relacjach symetrycznych:

Chciej mi także donieść co - kochany Bracie - o twojej najukochańszej żonie (mieszczanin do brata, 1831) PamL 40;

Zechciejcie mi to donieść (Seweryn Goszczyński do przyjaciela, 1842) GoszLis 148 .

\subsubsection{W rozmowach}

W kontaktach ustnych zależność między pozycją społeczną nadawcy i odbiorcy wypowiedzi jest słabiej widoczna:

Chciej waszmość pan powiedzieć (szlachta, poł. XVIII w.) BohK 1, 459; sim. ib. 138, 161, 421;

Chciejże mu waszmość pan także o zamęściu siostry mojej wspomnieć (szlachta, II poł. XVIII w.) BDr 60;

Chciej jaśnie wielmożny pan mieć wzglad na moje położenie (komornik do hrabiego, I poł. XIX w.) KorzKom 43;

Chciej kochana pani uważać (arystokracja, I poł. XIX w.) DzierzS 103;

Niech jegomość dobrodziej zechce napisać, bo ja nie wiem, jak to tam potrzeba (klient w redakcji, poł. XIX w.) KuczGodz 30.

\subsection{7. ,zechcesz”}

Jest to rzadka forma prośby; odnotowane użycia pochodzą wyłącznie z listów:

Zechcesz Dobrodziej [...] wspomnieć mię i uszanowanie moje mu oświadczyć (Grzegorz Piramowicz do Ignacego Potockiego, 1780) KorPot 78;

JWWPan Dobrodziej zechcesz łaskawie ocenić pobudki moje (Wincenty Pol do znajomego, 1844) LisPol 126. 


\subsection{8. „pozwól” + czasownik}

Forma ta pojawiła się w funkcji etykietalnej w końcu XVIII wieku. Wprowadzała ona czasownik odnosząc się do pożądanej czynności nadawcy: perlokucyjny (jak np. nosić w pierwszym przykładzie) lub, później, także illokucyjny prosić. $\mathrm{W}$ ten sposób w znaczeniu proszę zaczęto używać zwrotu pozwól prosić.

\subsubsection{W listach}

Mimo raczej ceremonialnego charakteru takich formuł, spotykamy je nie tylko wówczas, gdy nadawca zwracał się do osoby o wyższym od siebie statusie, ale również (choć rzadziej) w relacjach równorzędnych:

Pozwól W.K.M. nosić na piersiach ukochane imię moje (Adam Naruszewicz do króla, 1780) NarLis 487;

Co do mniej, pozwól, niechaj otwarcie powiem, ubogi jestem, ale poczciwy (sekretarz do Ignacego Potockiego, 1792) TKor 66;

Pozwól pomówić z sobą o sprawie publicznej (Karol Kniaziewicz do Tadeusza Kościuszki, 1799) LisKn 23;

Pozwól wasza Książęca Mość, abym się choć krótko do Jego wysokich i dobrotliwych przypisał względów (August Bécu do Adama Czartoryskiego, 1822) LisRS 44;

Nim jednak przystapię do oddania Panu zasłużonych pochwał za tak prześliczny wstęp, pozwól, że się z nim posprzeczam (literat do literata, 1842) KorGrab 36.

\subsubsection{W rozmowach}

W kontaktach bezpośrednich większość odnotowanych użyć to z kolei sytuacje, gdy interlokutorzy mają podobne rangi pragmatyczne, a ewentualna wyższość odbiorcy wynika z jego wieku lub pozycji w rodzinie:

Pozwólcie waćpanowie, ażebym jako pierwej przybyły miał pierwszeństwo do przyjęcia gości (oficer do kolegów, kon. XVIII w.) GodGr 32;

Pozwól waćpan dobrodziej powiedzieć sobie, żem jest przekonaną (szlachcianka do ojca, kon. XVIII w.) CzarKom 406;

Teraz pozwól, łaskawco, zadać sobie jeszcze jedno pytanie (szlachta, pocz. XIX w.) KuKas 137;

Pozwól więc, niech jadę, gdzie jedziesz (szlachcianka do męża, pocz. XIX w.) PamFel1, 417;

Pozwól mi pan choć w tej chwili wynagrodzić w sumieniu mojem ruinę z twej przyczyny (szlachcianka do ukochanego, I poł. XIX w.) OSP1, 146;

Pozwól mi zarazem prosić ciebie o jedno dobrodziejstwo (siostrzenica do ciotki, poł. XIX w.) BujSt 269. 


\subsection{9. ,pozwolisz" + czasownik perlokucyjny}

Funkcja jest tu taka sama jak w przypadku formy „raczysz”.

\subsubsection{W listach}

Zbyt skromny materiał nie pozwala na jednoznaczne stwierdzenie jaki układ nadawczo-odbiorczy najbardziej sprzyjał stosowaniu takich form w epistolografii:

Pozwoli Pani Dobrodziejka, ażebym JMCi Pani Cześnikowej [...] do nóg upadł (Franciszek Karpiński do matki swego ucznia, 1765) KarpKor 6;

Pozwolisz JO Pani, ażebym Cię położył na czele tych wszystkich... (Franciszek Karpiński do księżnej, 1791) KarpKor 39;

Pozwolisz jednak, kochany Edmundzie, że Ci tu zrobię uwagę (Wincenty Pol do przyjaciela, 1845) LisPol 144.

\subsubsection{W rozmowach}

Pewne przykłady tej konstrukcji pojawiły się w żywej mowie znacznie później, bo prawdopodobnie dopiero przed połową XIX w.:

Pozwoli jaśnie wielmożny pan zapytać (komisarz do hrabiego, 1844) KorzDram 263;

Pozwolisz, że rzucę kilka uwag nad temi dwoma charakterystycznymi numerami (znajomy do dziennikarza, 1848) KorKrak 1;

Pozwoli mama, że ja znów widząc ją tak rozgniewaną, Mani nie porzucę (arystokracja, poł. XIX w.) KraszDz 304;

Pozwolisz asindziej, że ja tu jutro u niego wypocznę (szlachcic do hrabiego, poł. XIX w.) KraszH 188.

\subsubsection{0. „bądź laskaw” + czasownik perlokucyjny}

Zwrot ten wchodzi w szersze użycie od końca XVIII wieku.

\subsubsection{W listach}

W ekscerpowanej korespondencji formuła ta pojawia się przede wszystkim w relacjach symetrycznych:

Badź WWPan laskaw wejrzeć we wszystkie artykuły mego gospodarstwa (Hugo Kołłątaj do barona, 1792) KołLis1, 9;

Niech Generał będzie łaskaw upewnić mnie (Karol Kniaziewicz do Henryka Dąbrowskiego, 1799) LisKn 13; 
Niech Pan będzie łaskaw uspokoić mnie w tym trochę (Salomea Słowacka do Antoniego Odyńca, 1827) LisRS 191;

Badź Poseł łaskaw i nie czyń tego we Francji publicznem (Stanisław Trentowski, 1837) TrenLis 12;

Niech Mama Dobrodzika będzie łaskawa zakomunikować Papie te szczegóły (Józef Kraszewski, 1840) KraszLis 94; sim. ib. 97; 120; 121;

Bąd́ łaskaw, napisz zaraz do mnie (literat do Józefa Kraszewskiego, 1842) KorGrab1, 133;

Bqdź łaskaw zawarty tu zaraz oddać Gaszyńskiemu (Zygmunt Krasiński do przyjaciela, 1846) KrasMał 35.

\subsubsection{W rozmowach}

Charakterystyczna jest w niektórych użyciach składnia bezspójnikowa typu badź taskaw przeczytaj; niech panowie będa łaskawi, uratuja. Zazwyczaj zapisywano takie połączenia bez przecinka. Podobnie jak w przypadku korespondencji dominują przypadki użycia w sytuacji, gdy interlokutorzy posiadali podobny status społeczny:

Bádź łaskaw, mości dobrodzieju, pomówmy no sobie (szlachta, kon. XVIII w.) CzarKom 401;

Panie dorożkarzu! Badź łaskaw przenieść Kopernika do króla Zygmunta, żeby się z sobą poznali (szewczyk, pocz. XIX w.) WójSp 102;

Niech panowie będa laskawi, uratują biedne dziewczęta od rozpusty (włościanie do szlachty, pocz. XIX w.) KoźPam2, 326;

Niech pan będzie łaskaw - powie mu, żeby śpiewał (arystokracja, po 1820) OlPam1, 156;

Niech pani dobrodziejka będzie łaskawa nie wspominać nic wcale o tem (porucznik do szlachcianki, 1826) SkarbSt 46;

Niech pan będzie łaskaw powiedzieć mi, dlaczego mi w tym numerze oto tyle przekreślono (dziennikarz do cenzora, I poł. XIX w.) JanAn 121;

Badź łaskaw przeczytaj teraz ten list (szlachcianka do szlachcica, lata 40. XIX w.) KorzDram 308.

\subsubsection{1. ,zmiłuj się", ,zlituj się" + czasownik perlokucyjny}

\subsubsection{W listach}

Słowa te, przydające prośbie intensywności, stały się modne w epistolografii w końcu XVIII w., a szczególnie chętnie używano ich w stuleciu następnym, prawie zawsze w listach do przyjaciół, bliskich znajomych, najbliższej rodziny:

Zmituj się Pani, albo napisz słówko jakie, albo zleć komu do napisania (arystokrata do znajomej, 1792) SzymLis 52; 
Zmituj się, bądź łaskaw jak najprędzej mi ten interes skończyć (Jan Śniadecki do przyjaciela, 1792) ŚniaLis 38; sim. ib. 30;

A zmiłuj sięż, a bój sięż Boga, a pisz! (Adam Mickiewicz do Tomasza Zana, 1820) KorFil 62;

Zmiluj się, nie zaniedbuj starać się o zdrowie (Jan Czeczot do Adama Mickiewicza, 1820) KorFil 97;

Zmituj się, mamo droga! Dopomnij się o te kroniki (Juliusz Słowacki, 1834) KorSł 214;

Zlituj się nade mną, nie mów mi o wzniosłych twoich marzeniach (Narcyza Żmichowska do brata, 1838) ŻmLis 66;

Zmituj się, wyprawcie to wszystko jak najprędzej (Seweryn Goszczyński do przyjaciela, 1839) GoszLis 50;

Zlituj się, Papo, o ten paszport proszę (Józef Kraszewski do ojca, 1845) KraszLis 124.

\subsubsection{W rozmowach}

Dowody użycia w wypowiedziach ustnych są wcześniejsze o kilkadziesiąt lat, zwracano się tak do równych lub wyższych rangą:

Zmiłuj się, daj mi waszmość pan tę książkę (szlachta, II poł. XVIII w.) BohK1, 322; sim. ib. 101, 142, 170;

Panie dobrodzieju, zmituj się, każ przynajmniej pięćset złotych wyliczyć (krawiec do sługi szlacheckiego, ok. 1770) CzarKom 190;

Zmiłuj się Cześnikówno dobrodziejko, nie dawaj mi rekuzy (szlachcic, XVIII/ XIX w.) BykPam2, 141;

A zmituj się, biegaj z Wężykiem, żeby temu zapobiegł (generał do generała, 1831) ZałWsp 375;

Zmiluj się panicz, nigdy nie powiadaj nikomu, ze ja o tem gadałam (chłopka do szlachcica, I poł. XIX w.) RaRa 24;

Zmituj się, nie przypraw mnie o kłopot (mieszczanin do przyjaciela, poł. XIX w.) KraszDz 37.

\subsection{CZASOWNIKI PERFORMATYWNE}

\subsection{1. „proszę"}

Sam czasownik performatywny proszę, bez żadnej ozdobnej obudowy, to bardzo częsty w analizowanym materiale sposób wyrażenia prośby. Jest to zjawisko wskazujące na uproszczenie etykiety w drugiej połowie XVIII w. i w wieku XIX, bo w epoce dawniejszej tego prostego sposobu, widocznego jeszcze w XVI w., 
już w następnym stuleciu używano bardzo rzadko ${ }^{5}$. Widzimy więc jakby nawrót do prostoty „wieku złotego”.

\subsubsection{1. „proszę" + imperativus}

\subsection{W listach}

Taka formuła jest charakterystyczna dla korespondencji między osobami bardzo sobie bliskimi, zazwyczaj będącymi ,na ty”. Najczęściej elementem obudowy etykietalnej jest tutaj forma adresatywna niewołaczowa (zaimkowa, pan) lub rzadziej wokatywna:

Więc proszę, przyjacielu, napisz (Karol Radziwiłł do arystokraty, 1773) KorRadz 91;

Bądź, proszę, thumaczem moim (arystokrata do starościny, 1792) SzymLis 26;

Proszę cię, odpisz mi (mieszczka do kochanka, 1793) LM 143;

Proszę Cię, numeruj listy (baron do córki, kon. XVIII w.) PamOśm2, 69;

Oświadcz, proszę, moje pozdrowienie i przyjaźń (Karol Kniaziewicz do Henryka Dąbrowskiego, 1801) LisKn 19;

Proszę Cię, najukochańszy Bracie, odpisz mi też (1832) PamL 39;

Proszę Cię, [...], donieś mi tedy, co to za człowiek? (Wincenty Pol do przyjaciela, 1832) LisPol 34;

Proszę Cię, przeczytaj Pismo święte (Zygmunt Krasiński do przyjaciela, 1841) KrasLis 9;

Proszę Cię, drogi, pisz i pisz (Zygmunt Krasiński do przyjaciela, 1846) KrasMał 50;

Proszę Cię, przyjedź (Józef Kraszewski do brata, 1845) KraszLis 128;

Proszę cię, pracuj nad tem pisemkiem (Teofil Lenartowicz do przyjaciela, 1852) LisLen 37;

Proszę, niech też mi Pan opowie, jak przepędził karnawał (Salomea Słowacka do Antoniego Odyńca, 1828) LisRS 288.

\subsection{W rozmowach}

W kontaktach bezpośrednich, tak samo jak w przypadku listów, warunkiem zastosowania tego typu formuły etykietalnej były bliskie relacje między rozmówcami. Świadectw używania takich aktów grzecznościowych w wypowiedziach ustnych jest bardzo dużo. Wybrane przykłady:

Konserwuj ten portret, proszę (panna do kawalera, II poł. XVIII w.) CzarKom 170;

\footnotetext{
${ }^{5}$ M. Cybulski, Obyczaje językowe..., s. 117.
} 
A! nie porzucaj mnie, prosze (żona do męża, kon. XVIII w.) PamOch4, 308;

Witkowski, nie masz tam chleba? Proszę cię, daj kawałek (żołnierz do żołnierza, pocz. XIX w.) PamWit 79;

Prosze, niech pan to zrobi dla mnie i nie wychodzi (szlachcianka do szlachcica, pocz. XIX w.) PamFel1, 94;

Tylko proszę, moja babciu, niech tu dziś do mnie nikt nie przychodzi (pocz. XIX w.) DemD 154;

Powiedz mi, proszę cię, co to znaczy (urzędnik do oficera, 1831) JanAu 237;

Proszę cię, Dioni, wystaraj mi się porcji lodów, bo okropnie gorąco (arystokratka do brata na balu, poł. XIX w.) Żm Pow2, 29;

Ojcze, nie płaczcie prosze (chłop, poł. XIX w.) KraszJer 151;

Mój drogi stryju, proszę cię, nie przymuszaj ją do widzenia się z sobą (poł. XIX w.) KraszDwa 96;

O, idźcie, matusiu! Idźcie, proszę, i spocznijcie (chłop, 1861) KraszSt 95.

\subsubsection{2. „proszę o”, ,proszę, aby (żeby, by)”, „proszę” + infinitivus}

Dwa warianty formuły, ,proszę o”, ,proszę, aby (żeby, by)”, stosowne były zwłaszcza (choć niekoniecznie) w listach oficjalnych i/lub kierowanych do osób szczególnie ważnych, a także gdy przedmiot prośby był ważny dla nadawcy.

\subsubsection{1. ,proszę o"}

\subsection{W listach}

Proszę JWMP. Dobr. jednak o rezolucyą [...] proszę o kompassyą JJWMM. Państwa Dobr (generał do hetmana, 1767) LisJak 101; 105;

Prosze WKMość o pobłażanie (wojewodzianka do króla, 1788) LM 133;

Proszę w tej okoliczności o dowód dobroci (Grzegorz Piramowicz do Ignacego Potockiego, 1790) KorPot 205;

Bardzo o to proszę (Hugo Kołłątaj do barona, 1792) KołLis 14;

Proszę Cię o niezawodny odpis przyszłą pocztą (do brata, 1831) PamL 43;

Matko, koniecznie proszę $o$ więcej otwartości w twoich listach (Juliusz Słowacki, 1833) KorSł 137;

Proszę Cię o błogosławieństwo Twoje (hrabia do matki, I poł. XIX w.) ŁozHis 18 ;

$O$ modlitwę za mną proszę (zakonnik do przełożonego, 1849) LisDuń 5;

Proszę o prędką odpowiedź, choć nie zasłużyłam (Narcyza Żmichowska do przyjaciółki, 1862) ŻmLis 192. 


\subsection{W rozmowach}

Mci panie marszałku, prosiemy o zagajenie sejmu (poseł, 1762) KitPam 129;

Mości Książę Marszałku proszę o głos (podczas sejmiku, II poł. XVIII w.) WybŻ 46;

Prosimy ciebie dla nas o pomoc (oficerowie do Jana Kilińskiego, 1794) PamOśm1, 263;

Proszę pana prezesa $o$ warunki (lekarz do szlachcica, poł. XIX w.) KraszJary 47.

\subsubsection{2. „proszę, aby (żeby, by)”}

\subsection{W listach}

Prosze WKMość, ażeby order dla niego na moje był przysłany ręce (hetman do króla, 1768) KonfB 55;

Proszę W.X.M. abyś wszystkie rozkazy i zdania moje odkrył (książę do biskupa, 1773) KorRadz 102;

Proszę Obywatela, abyś mi przysłał wiadomość o konduicie i odjeździe Pągowskiego (Karol Kniaziewicz do Henryka Dąbrowskiego, 1799) LisKn 12;

Ta potrzeba zmusza mię także prosić cię, abyś obrachował wartość tego co ci teraz posyłam (Seweryn Goszczyński do wydawcy, 1842) GoszLis 151;

Proszę, ażeby nazwisko moje z listy członków Towarzystwa wykreślone zostało (do zarządu, 1846) KorAlc 8;

Proszę Cię, Siostro kochana, abyś pozdrowiła ode mnie Brata Ludwika (zakonnik do współwyznawczyni sekty Towiańskiego, 1849) LisDuń 31.

\subsection{W rozmowach}

Proszę Państwa, abyście mi pozwolili dwa dni jeszcze bawić w domu waszym (kanonik do szlachty, kon. XVIII w.) PamGąs 234;

Mości panie Płaski. Maleńkiej bym się tylko domagała łaski, proszę, byś w sprawach naszych nie był tak gorliwym (hrabina do przyjaciela, I poł. XIX w.) NiemPod 1823;

Proszę pana, żebyś się rozmyślił (szlachta, poł. XIX w.) KraszDwa 295.

\subsubsection{3. ,proszę o łaskę, aby...”}

Zwroty proszę taski, aby...; proszę o taskę, aby itp. pojawiały się w prośbach szczególnie gorących, które zarówno w korespondencji, jak i w rozmowach były kierowane do osób o wyższej randze od nadawcy wypowiedzi: 


\subsection{W listach}

Proszę tedy taski JW.W.Pana, byś mnie zapewnił, co się to dalej dziać będzie (kasztelanowa do marszałka, 1790) LisKos 212; sim. ib. 226.

\subsection{W rozmowach}

Panie kochany! O jedną cię proszę łaskę: nie odprawiaj mnie waćpan (służąca do fabrykanta, II poł. XVIII w.) BDr 273;

O jedna taskę będe prosić Waszą Książęca Mość, to, żebym nie tracąc chwili mógł wrócić do żony (oficer, lata 20. XIX w.) BTP 334;

O jedna taskę proszę panią, aby mnie zostawić na parę lat w Warszawie (sługa do pani, I poł. XIX w.) BTP 235;

Proszęo tę łaskę, aby mi dał te sześć rubli (córka do ojca, poł. XIX w.) DmNa 126.

\subsubsection{4. „proszę” + infinitivus}

\subsection{W listach}

Wariant trzeci, ,proszę" z bezokolicznikiem, występował głównie w listach prywatnych, gdy nadawcę i odbiorcę nie dzieliła duża różnica rang pragmatycznych:

Sumę tę przystać niezawodnie proszę tu na miesiąc september (Ignacy Krasicki do brata, 1760) KKor 36;

Proszę mi podesłać konie choć do Bielska (generał do hetmana, 1767) LisJak 101;

Prosze przyjechać do Frankfurtu (siostra do Karola Radziwiłła, 1773) MorDiar 233;

Proszę MDobrodzieja przeczytać to z Jejmością Dobrodziejką (Grzegorz Piramowicz do Ignacego Potockiego, 1779) KorPot 40;

Prosze mnie informować o dalszych skutkach sprawy (Ignacy Krasicki do brata, 1781) KKor 2, 15;

Proszę nie być zazdrosnym, że ja w niebytności jego całuję w rączki panią kilka razy (Tadeusz Kościuszko do wojskiego Wielkiego Księstwa Litewskiego, 1789) KośWsp 11;

Proszę Obywatela Generała przesłać mi tych Officerów (Karol Kniaziewicz do Henryka Dąbrowskiego, 1799) LisKn 16;

Proszę mi wyznaczyć miejsce na granicy (Józef Poniatowski wyzywając na pojedynek, kon. XVIII w.) PamOśm5, 73;

Jeszcze raz proszę nie zapominać tak zupełnie o tej, którą Pan swą siostrą nazywał (Ewa Ankwiczówna do Adam Mickiewicza, 1833) OpDz 110;

Proszę się nie gorszyć z mego anti-abolitionizmu (literat do literata, 1842) GrabKor2, 50. 


\subsection{W rozmowach}

Konstrukcja taka występowała przede wszystkim w swobodnych rozmowach, gdy interlokutorzy posiadali podobny status społeczny:

Proszę ze mnie nie żartować (szlachcianka do konkurenta, II poł. XVIII w.) PamOch2, 281;

Proszę mi powiedzieć, co to waszmość panu do głowy przypłynęło, ni z tego ni z owego porzucić choragiew (służący do pana, II poł. XVIII w.) CzarKom 71;

Proszęż mnie chociaż tutaj zaniechać! (podstolina do kawalera, II poł. XVIII w.) ZabF 40;

Proszę przecie dobrze przyjmować mego przyjaciela (mąż do żony) ZabF 133;

Proszę pana sierżanta mnie to opowiedzieć (ułan, I poł. XIX w.) PamUł 21;

Proszę mi dać spokój (szlachcianka do sąsiadki, I poł. XIX w.) KorzDz 58;

O panu hrabi proszę przy mnie nie mówić tak lekko (lekarz do wierzyciela, poł. XIX w.) KraszJary 84.

\subsubsection{3. ,proszę bardzo”}

Spośród różnych możliwych okoliczników wzmacniających akt prośby najczęstszy był przysłówek bardzo. Zwracano się w ten sposób do rodziny i przyjaciół zarówno w listach jak i w kontakcie bezpośrednim:

\subsection{W listach}

Proszę bardzo, Mci Kochany Bracie, ażebyś posłał [...] zł piędziesiąt (Ignacy Krasicki do brata, 1767) KKor1, 165;

Bardzo o tę grzeczność prosze (Ignacy Krasicki do przyjaciela, 1773) KKor 235;

Proszę Pana bardzo, ażeby do mnie pisywał teraz na ręce Julka (Aleksandra Bécu do Antoniego Odyńca, 1828) LisRS 354;

Proszę Cię bardzo o portret twój, Zosi i Stefana (Adam Mickiewicz do Antoniego Odyńca, 1833) KorMic 79;

Proszę bardzo o zwrot tego listu (zakonnik do współwyznawców sekty Towiańskiego, 1853) LisDuń 220.

\subsection{W rozmowach}

Proszęż bardzo, żeby mi tego więcej nie było (żona do męża, I poł. XIX w.) KorzSt 37;

Bardzo proszę zachować się przyzwoicie względem tej panny (żona do męża, lata 40. XIX w.) RusWar2, 183; 
Romualdzie, nie drażnij go, bardzo cię proszę (mieszczanin do przyjaciela, poł. XIX w.) ŻmPow1, 267.

\subsubsection{4. „(proszę) na miłość Boską”}

Prośby wzmacniane formułą odwołującą się do sacrum to w korespondencji nowopolskiej rzadkość:

Na miłość Boga mi odpowiedz; na miłość Boga cię proszę (Zygmunt Krasiński do przyjaciela, który długo nie odpisywał, 1838) KrasJar 14;

Na miłość Boska, nie używaj Pani do niej czarnych pieczątek! (lekarz do przyjaciółki, 1839) MorLis 45.

W epoce średniopolskiej były one bardzo chętnie stosowane ${ }^{6}$; jak widać, w nowszych czasach obyczaje epistolarne uległy pewnej laicyzacji.

\subsubsection{5. ,proszę" + inne okoliczniki}

Jest to niezbyt liczna grupa wyrazów i wyrażeń. Zniknęło więc niemal bez śladu bogactwo epoki średniopolskiej, kiedy to były w użyciu m.in. okoliczniki wielce, pilnie, pokornie, uniżenie (nisko, poniżenie), braterskie, miłościwie, niestychanie i inne, nieraz powtarzane i mnożone ${ }^{7}$. Zebrany materiał pokazuje, że takie formuły próśb zarówno ustne jak i pisemne kierowano do osób o podobnym statusie społecznym do nadawcy wypowiedzi.

\subsection{W listach}

W początkach epoki widać jeszcze ślady mody na latynizmy:

Zostaje mi zatem ordenter prosić WM. Pana (wojewoda do kasztelana, 1753) PamKosz 126;

Proszę JMci, Kochany Dobr., instanter, instantius, instantissime, ażebyś raczył gdzie dostać książkę (Ignacy Krasicki do przyjaciela, 1765) KKor 102;

Na miłość ojcowska Cię proszę, abyś Królowi, ile tylko można, przywiązanie swoje oświadczał (ojciec do hetmana polnego, 1776) RzewKron 115;

Proszę serdecznie, abyś przyjaciół wszystkich obligował w Komisji (kasztelanowa do siostrzeńca, 1790) LisKos 212;

I jeszcze tysiqc razy proszę o miniaturę (krewna do Adama Mickiewicza, 1821) KorFil 262;

Wszystko to niech Babunia Dobrodziejka, najusilniej proszę, nie weźmie za próżność (Józef Kraszewski, 1834) KraszLis 49;

\footnotetext{
${ }^{6}$ M. Cybulski, Obyczaje językowe..., s. 125-129.

${ }^{7}$ Ibidem, s. 119-122.
} 
Proszę Cię mocno, abyś tej lekcji nie odmówił (Władysław Witwicki do Fryderyka Chopina, 1840) ChopKor2, 7;

Najmocniej Papy Kochanego proszę i przepraszam (Józef Kraszewski do ojca, 1843) KraszLis 116.

\subsection{W rozmowach}

Proszę waszmość pana uniżenie, abyś wszystkich swych ludzi kazał wziąć w kajdany (szlachcic do szlachcica, II poł. XVIII w.) BohK2, 254;

Proszę serdecznie, nie odmawiaj (szlachta, II poł. XVIII w.) ŁozG 42;

A ja proszę najpokorniej waszmość pana dobrodzieja od nauczania jego osoby mnie uwolnić (ksiądz do szlachcica, II poł. XVIII w.) RzewLis1, 263;

Na mitość Boga, proszę cię, panie Feliński, nie wychodź ze swego pokoju (szlachcianka, pocz. XIX w.) PamFel1, 94.

\subsubsection{6. „rzucam mię pod nogi i proszę” itp.}

Bardzo modne w wiekach XVII i XVIII formuły wyrażające uniżoność i pokorę przez nazwanie ostentacyjnego gestu ${ }^{8}$ wychodziły z użycia w okresie oświecenia. Zupełnie wyjątkowo trafiały się one w listach do osób wysoko postawionych:

Rzucam mię pod nogi WKMości i Jego wsparcia proszę (Adam Naruszewicz do króla, 1774) KorNar 24;

Sktadają mnie u nóg Pana, o jednę łaskę śmiem prosić (sekretarz do Ignacego Potockiego, 1793) TKor 214.

\subsubsection{7. ,proszę, racz (chciej)” itp.}

Opatrywanie czasownika performatywnego proszę formą modalną słów raczyć albo (rzadziej) chcieć to zjawisko wychodzące z użycia. Większość przykładów pochodzi z XVIII wieku, a wszystkie z listów:

Proszę wcześnie racz mi WKMość przysłać w tym moją dyspozycyę (hetman do króla, 1768) KonfB 111;

Proszę Cię, racz nam donieść, co tam o edukacyi myślą (Jan Śniadecki do znajomego, 1788) ŚniaLis 11;

Prosze JW. Pana racz ordynacją sądu przeczytać (Tadeusz Czacki do Hugona Kołłątaja, 1806) KołCzac 78;

Proszę Pana, niech Pan raczy zważyć dobrze wszystkie te okoliczności (Salomea Słowacka do Antoniego Odyńca, 1827) LisRS 196;

${ }^{8}$ Ibidem, s. 123-124. 
Proszę, żebyś raczyła stale być przekonaną o najstalszych zawsze sentymentach (arystokrata do starościny, 1792) SzymLis 42;

Prosze JWPana, chciej go czasem w odezwach nie przepomnieć (sekretarz do Ignacego Potockiego, 1793) TKor 130.

Proszę Mamy, żeby była łaskawa przysłać mi dzieło moje o Literaturze (Maurycy Mochnacki, 1832) MochLis 153.

Choć przedstawione powyżej formuły sprawiają wrażenie dość ceremonialnych, to jednak zazwyczaj stosowano je w relacjach symetrycznych.

\subsubsection{Powtórzenie wykładnika prośby}

Wzmocnieniu prośby służyło też podwojenie lub potrojenie czasownika illokucyjnego. Zdarzało się rzadko (wszystkie przykłady z listów):

Darujesz mi WWMc Pan Dobrodziej, że Go zatrudniam pisaniem moim, proszqc, proszqc, ażebyś mi o JO Krakowskiej donieść raczył (Franciszek Karpiński do podskarbiego białostockiego, 1790) KarpKor 36;

Napisz mi parę słów, proszę, proszę, proszę (Fryderyk Chopin do Józefa Elsnera, 1840) ChopKor2, 10;

Prosze i jeszcze raz proszę o list (Wincenty Pol do znajomego, 1843) LisPol 103.

\subsubsection{Tryb przypuszczający: ,prosiłbym”}

Tryb przypuszczający słowa illokucyjnego to dość rzadki środek wyrażania prośby. Podkreślał jej usilność i jednocześnie zwiększał poziom honoryfikatywności formuły.

\subsection{W listach}

Odnotowane przykłady pochodzą wyłącznie z listów pisanych w XVIII wieku do osób o wyższej randze pragmatycznej od nadawcy:

Prositbym jednak WKMci, abyś mu na moje ręce przysłał jaki prezent (hetman do króla, 1768) KonfB 52;

Prositbym o dopełnienie tej łaski (Adam Naruszewicz do króla, 1791) KorNar 384;

Prositbym wszelako o cyfrę jaką (sekretarz do Ignacego Potockiego, 1792) TKor 38;

Jeżelibym mógł zyskać łaskę JWPana Dobr., prositbym, aby póki to prześladowanie w Polszcze będzie, żeby żadnej łaski nikomu nie wydano na moje beneficya (Hugo Kołłątaj do Stanisława Małachowskiego, 1793) KołLis2, 75. 


\subsection{W rozmowach}

Moda na konwersacyjne prosiłbym przyszła dopiero w połowie XIX wieku, zatem znacznie później forma ta upowszechniła się w żywej mowie niż w epistolografii, w której miała źródło:

Prositbym tylko o pozostanie wszystkich trzechset kozaków przy mnie (szlachcic do księcia, kon. XVIII w.) Pam Och2, 187;

Prositbym tylko pani, abyś [...] była łaskawą nic mi nie mięszać i nie przeszkadzać (prezes do pułkownikowej, poł. XIX w.) KraszDwa 367;

Panie Gagolewski, prositbym pana na słówko (szlachcic do sędziego, poł. XIX w.) ŁozDw 193;

Prosiłbym tylko o jaką bliższą informację (urzędnik do prezesa, poł. XIX w.) ŁozNoc 29;

Jeżeli to więc nie zrobi panu jakiego ambarasu, to prosiłbym o dozwolenie mi poczekania w redakcyi (do redaktora, poł. XIX w.) KuczGodz 9;

Jeżeliby to nie przechodziło zakresu pańskiej grzeczności, prosiłabym ogień poprawić (szlachcianka ironicznie do szlachcica, poł. XIX w.) FrDz 2.

Inaczej niż w przypadku korespondencji, zakres użycia formuł ustnych nie był ograniczony do sytacji, gdy nadawca miał niższy status od odbiorcy.

\subsubsection{0. ,śmiem prosić”, „ośmielam się prosić” itp.}

Pierwszy z tych honoryfikatywnych czasowników kontynuuje stan starszy, bo wcześniej stosowano go często w tej funkcji ${ }^{9}$. Natomiast czasownik ośmielam się to nowopolska innowacja. Oba wyrażały uniżoność proszącego - również w przypadku relacji symetrycznej. Wszystkie przykłady wystapiły w listach:

Śmiem upraszać łaski Pańskiej, ażebyś, JW. Panie, raczył determinować przynajmniej ks. Gzowskiego (Adam Naruszewicz do podskarbiego, 1777) KorNar 65;

Ośmielam się prosić o przyspieszenie pracy (Tadeusz Czacki do Hugona Kołłątaja, 1806) KołCzac 278;

Doznając najszacowniejszej łaski Pana, ośmielam się prosić o tom inny tego dzieła (Alojzy Osiński do Hugona Kołłątaja, 1806) KołCzac 121;

Ośmielam się jeszcze prosić JWPana Dobr. o radę i objaśnienie względem porządku i układu nauki (Euzebiusz Słowacki do Jana Śniadeckiego, 1811) LisRS 19.

To samo w trybie przypuszczającym:

Śmiatbym go prosić o sąd w tej mierze (Euzebiusz Słowacki do Hugona Kołłątaja, 1806) LisRS 13.

$\mathrm{Z}$ innym słowem lub zwrotem honoryfikatywnym:

Poważam się więc najusilniej prosić W Kr Mość o umieszczenie go w wojsku (wojewodzianka, 1788) LM 132;

9 Ibidem, s. 132. 
Mam honor zarazem prosić pana, abyś był łaskaw uwiadomić mnie o stanie zdrowia (generał do generała, 1812) PamWoj 206.

\subsection{2. "upraszam"}

Czasownik illokucyjny upraszam, chętnie stosowany od drugiej połowy XVII wieku, wyrażał prośbę intensywniej i miał zawsze frekwencję niższą niż proszę. Występował zwykle w konstrukcjach upraszam o i upraszam, aby...; konstrukcja z bezokolicznikiem była bardzo rzadka. Upraszam to właściwość próśb listownych; w rozmowach prawie tego słowa nie używano.

\subsubsection{W listach}

Upraszam JW. Pan, abyś miał względy na sejmiki (kasztelanowa do brata, 1763) LisKos 31;

Upraszam o ich przysłanie (Adam Naruszewicz do starosty żmudzkiego, 1773) KorNar 19;

Upraszam JWP Dobrodzieja kazać mię pisaniem do Wilna obwieścić (Grzegorz Piramowicz do Ignacego Potockiego, 1782) KorPot 115;

Zaczem upraszam W. Pana, ażebyś ułatwił mu zaspokojenie tych dwóch interesów (Hugo Kołłątaj do barona, 1792) KołLis 7;

O listę przechodzących rozkazy upraszamy (Joachim Lelewel do znajomego, 1832) LelNie 28;

Tylko o jedną flaszkę i tego, i tego specjału upraszam (lekarz do przyjaciółki, 1838) MorLis 34;

Upraszam w tym razie o największą szczegółowość (literat do hrabiego, 1842) KorGrab2, 59; sim. ib. 53; 58;

Upraszam o wyznaczenie mi niezapełnionej chwili (Wincenty Pol do znajomego, 1845) LisPol 143;

Upraszam drogiego Mistrza o uczucie jego i uwagi co do służby tej (zakonnik do współwyznawców sekty Towiańskiego, 1855) LisDun 290.

Pojawiały się typowe w takich kontekstach określenia wzmacniające prośbę:

- tryb przypuszczający:

Upraszałbym więc, aby je W. Ks. M. u siebie naprzód umieścić pozwolił (Stanisław Trembecki, 1801) TremNie 112;

- okoliczniki bardzo, pokornie, najpokorniej, najusilniej, jako najusilniej, uniżenie, wielce, najmocniej:

O co ja bardzo upraszam (prymas do hetmana, 1763) PamKasz 120;

$\mathrm{O}$ tę sumę, aby była zaciagniona, wielce upraszam (Ignacy Krasicki do brata, 1766) KKor1, 146; 
Upraszam więc jako najusilniej Jaśnie Oświeconego Pana, abyś... (Adam Naruszewicz do wojewody, 1774) KorNar 20;

Najmocniej upraszam o jakąkolwiek cyfrę (sekretarz do Ignacego Potockiego, 1792) TKor 44;

Upraszam W.K.M. pokornie o wstawienie się za temi mojemi dobrami, które są darem pańskim (Adam Naruszewicz do króla, 1793) NarLis 494;

Upraszam bardzo o wyroby ,pisanej” literatury warszawskiej (literat do literata, 1842) KorGrab2, 106;

Obojga Państwa najpokorniej upraszam o niezrywanie, a raczej o nieostyganie w stosunkach z nami (Adam Pług do Pauliny Wilkońskiej, żartobliwie, 1851) WilkWsp 281;

Upraszam przeto najusilniej szanownego Pana Dyrektora o udzielenie mi tych kilku fl. (Helena Modrzejewska, 1863) KorMod 45-46;

- słowa śmiem (także grzecznościowo zaprzeczone), mieć honor, mieć zaszczyt jako elementy orzeczenia modalnego:

Nie śmiem JWP Dobrodzieja upraszać, abyś dał rozkaz p. kapitanowi względem mojego małego ekwipażu (Grzegorz Piramowicz do Ignacego Potockiego, 1780) KorPot 82;

Śmiem upraszać JW. WM. Pana, abyś ten edykt uchylił (kasztelanowa do marszałka, 1790) LisKos 235;

Mam honor upraszać W.K. Mości o łaskawe podpisanie mi dymisji (Tadeusz Kościuszko do króla, 1792) KośWsp 28;

Mam zaszczyt upraszać o udzielenie mi ustnej odpowiedzi (pułkownik do księcia, pocz. XIX w.) SkarbPow 81;

- słowo raczyć jako orzeczenie zdania podrzędnego:

abyś sługę swojego biletem u tego Prałata poratować raczyt (Adam Naruszewicz do króla, 1774) KorNar 25;

Upraszam WMMć Pana Dobrodzieja, ażebyś przyłączony diariusz sądów Trybunału Najjaśniejszemu Panu prezentować raczyt (Franciszek Karpiński do sekretarza sejmu, 1782) KarpKor 21;

Upraszam za nim W.K.M., ażebyś raczyt [...] użyć prawa swego (Adam Naruszewicz do króla, 1790) NarLis 493;

Upraszam WMPana Dobrodzieja, abyś skutecznie te uwagi raczyt delegacyi przełożyć (profesor do Hugona Kołłątaja, 1791) ŚniaLis 20;

Upraszam JWPana, abyś mnie zdaniem swojem wesprzyć raczył (Hugo Kołłątaj do Ignacego Potockiego, 1793) KołLis2, 50;

Upraszam łaski WPana Dobr., abyś raczył ów pakiecik [...] odesłać (Fryderyk Chopin do Wacława Hanki, 1831) ChopKor1, 174; sim. ib. 224;

Upraszam, abyś ją oddać raczyt panu Janowi (Wincenty Pol do znajomego, 1843) LisPol 105.

Zgromadzony materiał pozwala stwierdzić, że formuły epistolarne, których ośrodkiem jest upraszam, kierowano zarówno do osób o wyższym statusie spo- 
łecznym od piszącego, jak i do adresatów o statusie zbliżonym do nadawcy. Jeśli różnica rang obu stron korespondencji była bardzo duża, stosowano kombinację różnych leksykalnych i gramatycznych elementów obudowy etykietalnej, np.:

O co przy pokornym do nóg upadaniu upraszajac (Franciszek Karpiński do magnata, 1763) KarpKor 4;

Ośmielam się przeto upraszać łaski Pańskiej, abyś mi w niniejszej okoliczności dopomóc raczył (kancelista KEN-u do Ignacego Potockiego, 1779) KorPot 47.

\subsubsection{W rozmowach}

Nieliczne przykłady użycia takich formuł w kontakcie bezpośrednim ograniczone są do relacji asymetrycznych, gdy nadawca miał niższą rangę pragmatyczną od odbiorcy:

Upraszamy waszmość pana dobrodzieja o audiencję (guwerner do chlebodawcy, II poł. XVIII w.) BohK1, 118; sim. ib. 2, 25;

Mon Prince, jestem wynagrodzony należycie, upraszam tylko patent na krzyż (ułan do księcia, I poł. XIX w.) PamUł 20;

Oto cię tylko upraszam, łaskawy panie, abyś jej skłonności nie stał na przeszkodzie (szlachcic do ojca ukochanej, I poł. XIX w.) SkarbSt 94;

Ja papę przy tem jeszcze raz upraszam, aby mi papa i na drugi miesiąc zaliczył trzy ruble (szlachcianka, poł. XIX w.) DmBa 125.

\subsection{3. "suplikuje"}

Czasownik illokucyjny suplikuję modny stał się w etykiecie epistolarnej od XVIII wieku, podobnie jak kilka innych latynizmów, i początkowo wyrażał większą intensywność prośby. Jak wynika z zebranego materiału, nie przeżył on przełomu XVIII i XIX wieku. Używano go w listach do osób o równej lub wyższej randze od nadawcy:

Suplikuje, aby mi ten list był posłany na pierwszą pocztę (szlachcic do hetmana, 1760) LisJak 19;

Suplikuję tego WMPana, per omnes teneritudines braterskiego serca, nie czynić zawodu tej mojej prośbie (Ignacy Krasicki do brata, 1760) KKor 46; sim. ib. 91;

Jeżeli mogę mieć z łaski JW. Pana i libertację na dobra moje, to suplikuję (kasztelanowa do brata, 1767) LisKos 66; sim. ib. 56, 65;

Bardzo suplikuję W.K.M. za nim (Adam Naruszewicz do króla, 1780) NarLis 485;

Suplikuję rozkazać powiedzieć Prawikowskiemu, w którym miejscu bryczka stoi (Stanisław Trembecki do pułkownika, 1802) TremNie 240. 
Obudowanie takich próśb intensyfikującymi dodatkami było rzadkie. Predylekcję do szczególnej uniżoności miał Stanisław Trembecki:

Na miłość Bóstwa i ludzkości najusilniej suplikuję, abyś Wasza Książęca Mość jako mój Protektor dopomóc mi dobroczynnie raczyt [...]. Wypada mi jeszcze najusilniej suplikować [...] Odważam się więc suplikować, abyś Wasza Książęca Mość zalecił ... (Stanisław Trembecki do ks. Czartoryskiego, 1801-2) TremNie 221; 222; 231;

Suplikuje bardzo a bardzo mój ten bilet odzyskać (Stanisław Trembecki do pułkownika, 1802) TremNie 237.

W rozmowach czasownik suplikuje jest prawie zupełnie nieobecny. Charakterystyczny i wyjątkowy zarazem przykład: gdy nie skutkuje wypowiedź: Ale proszę, mości panie skarbniku!, następuje intensyfikacja: Ale suplikuję, mości panie skarbniku (poł. XIX w.) KK 118.

\subsection{4. "dopraszam się"}

Czasownik dopraszać się wchodził z rzadka w skład formuły prośby tylko w wieku XVIII i jedynie w epistolografii:

Dopraszam się więc rozkazów i ojcowskiej rady (Karol Radziwiłł do Wacława Rzewuskiego, 1764) RzewKron 235;

Bardzo się dopraszam przysłania memoriału (Ignacy Krasicki do przyjaciela, 1765) KKor 107 ;

Wielką mi łaskę J. W. Pan uczynisz, gdy mi ten fawor wyjednasz, o co jako najusilniej dopraszam się (kantor krakowski do Ignacego Potockiego, 1787) KorPot 157;

Dopraszam się za największą łaskę JWPana Dob., aby tylko na mnie jednym był uskutecznionym (Tadeusz Kościuszko do Szczęsnego Potockiego, 1792) KośWsp 30.

Wydaje się, że ten typ prośby kierowano głównie do osób o wysokim statusie społecznym, jednak zbyt skromny materiał nie pozwala tego jednoznacznie ocenić.

\subsection{5. ,życzyłbym"}

Także do XVIII wieku i do epistolografii ogranicza się rzadka, znana od XVI wieku ${ }^{10}$, etykietalna forma prośby życzyłbym kierowana do osób o wyższej randze od piszącego:

${ }^{10}$ Ibidem, s. 137. 
Życzyłbym sobie, ażeby ten interes mógł być z łaski WKM przypomniony (Adam Naruszewicz do króla, 1777) KorNar 67;

Życzyłbym sobie, Panie Miłościwy, abym z tejże litości pańskiej mógł być przy boku biskupa (Adam Naruszewicz do króla, 1779) NarLis 496;

Życzyłbym, abyś był pomocą Ojczyźnie swojej (Tadeusz Kościuszko do wojskiego Wielkiego Księstwa Litewskiego, 1791) KośWsp 26.

Formy indykatywnej użył później Adam Mickiewicz w liście do Józefa Jeżowskiego:

Życzę także prospektów z parę i biletów kilkadziesiąt (1821) KorFil 209 - to już wówczas rzadki archaizm ${ }^{11}$.

\subsection{6. ,zaklinam" i ,błagam”}

Czasowniki zaklinać i błagać nie były składnikami etykiety średniopolskiej. Stały się nimi dopiero w końcu XVIII i w wieku XIX w tej funkcji zwiększyły frekwencję. Trudno w nich nie widzieć przejawów nowej obyczajowości eksponującej ekspresję uczuć, szerzącej się wtedy pod wpływem idei sentymentalizmu i romantyzmu.

Oba czasowniki były nacechowane emocjonalnie w stosunku do podstawowego czasownika illokucyjnego prosić. Zwiększeniu emocjonalności służyło eksponowanie dopełnień tych czasowników: „zaklinam na żoneczkę i dziatki, na Boga, na wszystko, co..." itp.

\subsubsection{1. ,zaklinam”}

\subsection{W listach}

Nie jest zapewne przypadkiem, że większość cytowanych dalej sformułowań wyszła spod piór romantycznych artystów słowa. Pisano tak zarówno do zwierzchników, jak i do przyjaciół czy najbliższej rodziny:

Zaklinam na wszystko, co jest w życiu najmilszego, to jest żoneczkę i dziatki, [...] abyś chciał JW. Pan Dobrodziej wyrwać mnie z miejsca tak nieprzyjemnego (Tadeusz Kościuszko do zwierzchnika, 1790) KośWsp 12;

Zaklinam JW. Pana, żebyś był spokojny (sekretarz do Ignacego Potockiego, 1792) TKor 28;

Zaklinam, abyś raczyt dowiedzieć się o miejscu jego pobytu (Adam Mickiewicz pyta majora o swego brata, 1831) KorMic 51; sim. ib. 54;

${ }^{11}$ Ibidem. 
Zaklinam ciebie, abyś mi jak najprędzej choć kilka słów napisała (Juliusz Słowacki do matki, 1831) KorSł 37;

Strzeż się i porachuj z własnych sił sumieniem, o to zaklinam ciebie (Zygmunt Krasiński do przyjaciela, 1838) KrasPot 49;

Zaklinam Cię na przywiqzanie do mnie i do dzieci, żebyś mnie w tej dręczącej niepewności nie zostawiała (Wincenty Pol do żony, 1841) LisPol 78;

Zaklinam, żebyś się tą nieprzyzwoitą krytyką nie zrażał (literat do literata, 1842) KorGrab2, 17;

Na Boga, zaklinam, niech mi Papa przysyła świadectwo (Józef Kraszewski do ojca, 1845) KraszLis 128.

\subsection{W rozmowach}

Świadectwa używania takich formuł w dialogach pochodzą z XIX wieku. Przeważają wypowiedzi cokolwiek pompatyczne kierowane często do osób bliskich:

Malwino, na wszystko, co ci tylko jest drogiem $w$ świecie, zaklinam cię, nie porzucaj mnie (ziemianin do ukochanej, XVIII/XIX w.) WirMal 32;

Mój synu, [...] zaklinam cię, nie bądź powodem zniewagi domu bożego (zakonnik do szlachcica, XVIII/XIX w.) BykPam2, 296;

Drogi ojcze! Zaklinam cię na chwałe naszego imienia, na miłość ku ojczyźnie, oświadcz przychylne zdanie twoje dla dobrej sprawy! (I poł. XIX w.) SkarbTar 103;

Zaklinam panią na wszystko! Chciej mnie wysłuchać (do znajomej, lata 40. XIX w.) RusWar2, 154;

Najmilsza pani, nie słuchaj, zaklinam cię, doktorów (szlachic, poł. XIX w.) BujSt 24;.

Na Boga zaklinam cię, uspokój się, utul moja Jaryno (do żony, poł. XIX w.) KraszJary 56.

\subsubsection{2. „błagam”}

\subsection{W listach}

W epistolografii zakres użycia takich nacechowanych emocjonalnie próśb wydaje się być ograniczony do listów pisanych do osób, z którymi łączyła nadawcę pewna zażyłość:

O dwie łaski błagam Cię, Najlepszy Bracie (sekretarz do Ignacego Potockiego, 1792) TKor 41;

Malwinko, o jednę i ostatnią błagam cię łaskę! (ziemianin do ukochanej, II poł. XVIII w.) Wir Mal 36;

Błagam Cię tylko, droga Wikciu, abyś nie odrzucała mej prośby (Narcyza Żmichowska do siostry, 1833) ŻmLis1, 219; 
Pamiętaj, błagam cię u wstępu do życia, pamiętaj (Zygmunt Krasiński do przyjaciela, 1840) KrasPot 240;

Błagam Cię więc przez przyjaźń, jaką masz dla naszego domu, oszczędź nam przykrości (do przyjaciela, poł. XIX w.) KuczGodz 6.

\subsection{W rozmowach}

I tu dominuje patos literackich dialogów, których bohaterowie pozostają w bliskich relacjach:

Błagam cię raz w życiu, uczyń zadość mej prośbie i daj mi szczęście moich dzieci (żona do męża, XVIII/XIX w.) BykPam2, 295;

Błagam cię, ażebyś dar ten ubogi od mego służki przyjęła (przyjaciel do wojewodziny, pocz. XIX w.) WójN 169;

Najprzód błagam cię, Emilio, abyś mię nie posądzała o niewdzięczność (szlachcianki, I poł. XIX w.) KorzDr 360; sim. ib. 259;

Błagam cię, żebyś mi błogosławieństwa nie odmawiał (syn do ojca, poł. XIX w.) KraszDwa 439.

\subsubsection{Kombinacje różnych czasowników}

Wzmacnianie prośby drogą synonimów było cechą zwłaszcza epistolografii. Szczególnie częste było połączenie proszę $i$ zaklinam:

Proszę WKMość o pobłażanie, gdyby prośba moja wydała się zuchwała, zaklinam Go, aby została w tajemnicy (wojewodzianka do króla, 1788) LM 133;

Proszę więc, najukochańszy Bracie, i zaklinam na wszystko, abyś mi mógł przez tę okazję odesłać (mieszczanin do brata, 1831) PamL 37;

Proszę cię, zaklinam cię, nie męcz mnie o to (Zygmunt Krasiński do przyjaciela, 1838) KrasPot 30;

Niech się Pan zlituje, proszę, zaklinam na wszystko, co Panu święte i miłe (Salomea Słowacka do przyjaciela, 1853) LisRS 336.

W dialogach to rzecz rzadka:

Ach, luby majorze, / Proszę cię, błagam, błagam w największej pokorze, / Puść mnie stąd (I poł. XIX w.) FrDz1, 107;

Proszę i błagam ciebie, dostojny mężu, nie opuszczaj nas (do marszałka sejmiku powiatowego, poł. XIX w.) WilkWsp 251.

O użyciu takch próśb decydował chyba nie tyle status społeczny nadawcy i odbiorcy, co duża determinacja proszącego.

Warto wspomnieć, że taki zabytek baroku jak żebrzę ${ }^{12}$ dał o sobie znać tylko raz u progu doby nowopolskiej:

12 Ibidem, s. 137. 
Ja o nie jako najpokorniej żebrzę (Ignacy Krasicki prosi matkę o pieniądze, 1759) KKor 27.

\subsubsection{Formy analityczne}

Formy złożone typu 1. os. czasownika + prośbę to właściwość polszczyzny pisanej. Wtórnie mogły się one pojawić i w mowie, ale bardzo rzadko, dopiero w XIX wieku i w jednej tylko konstrukcji: mam też do kolegi niewielką prośbe (I poł. XIX w.) PamUł 45; mam do jegomości prośbę (poł. XIX w.) KraszDwa 418, sim. KraszJary 45.

Wszystkie inne cytowane przykłady pochodzą z listów.

\subsubsection{1. „niosę (wnoszę, zanoszę itp.) prośbę” i warianty}

Tradycyjny zwrot, zawsze z przydawką przymiotnikową lub zaimkową, używany od dawna w listach i w pismach urzędowych. W dobie nowopolskiej nadal był stosowany, głównie jednak w wieku XVIII, i nadal tylko w pismach oficjalnych. Miał on różne warianty formalne, starano się bowiem o ozdobną różnorodność stylistyczną próśb pisemnych. Z badanej korespondencji wynika, że prośby tak sformułowane kierowano do osób o wyższej randze pragmatycznej od nadawcy:

Niesiemy przeto do JWP Dobrodzieja najpokorniejsze prośby, abyśmy od tak znacznego nas uszkodzenia łaskawą Pańską zasłonieni być mogli protekcją (nauczyciele do Ignacego Potockiego, 1777) KorPot 26;

Odważam się moje niegodne zanosić prośby (profesor do Ignacego Potockiego, 1781) KorPot 99;

Dowody łaskawości Pańskiej mnie oświadczone dają śmiałość przy złożeniu siebie u nóg JWWMP Dobrodzieja moja zanieść w tym punkcie prośbę (pisarz grodzki do Ignacego Potockiego, 1785) KorPot 143;

Śmiem w pełnej ufności nieść prośbe moja do tego, któremu kraj, edukacja publiczna i stan akademicki winne największą opiekę i wdzięczność (prorektor do Ignacego Potockiego, 1790) KorPot 214;

Niose pokorna prośbe moję do WKM za JP Wężykiem (Adam Naruszewicz do króla, 1794) KorNar 470;

Poważam się zanieść do wielmożnych państwa najuniżeńsza prośbe moje (szlachcic do rodziców ukochanej, 1826) SkarbSt 28.

3.2.7.2. „składam (przekładam, przedkładam) prośbę u stóp” i warianty

Jest to kancelaryjny relikt dawnego gestu składania dokumentu u stóp władcy. Występował do początku XIX wieku głównie w listach do przełożonych: 
Vota moje i prośby [...] składam u stóp pasterskich (Ignacy Krasicki do biskupa, 1762) KKor 65;

Prośby moje u nóg Jego składam, abyś w Prześw. Komisji Edukacyjnej raczył mnie łaską swoją wesprzeć (korespondent zagraniczny KEN-u do Ignacego Potockiego, 1778) KorPot 37;

Składam u nóg tronu prośby o najwyższe do króla Jmci Pruskiego udanie się (Karol Radziwiłł do króla, 1784) KorRadz 140;

Łaskawość JWWMP Dobrodzieja ośmiela mię przełożyć Mu prośbę moję listownie (ks. Onufry Kopczyński do Ignacego Potockiego, 1784) KorPot 141;

Wiadomość o chęci najjaśniejszych stanów [...] ośmiela mnie w tym celu złożyć prośbę moja przy nogach twórcy i opiekuna edukacji (prorektor do Ignacego Potockiego, 1790) KorPot 213;

Tę moję prośbę sktadajac u nóg Pańskich upraszałbym o rezolucję (Adam Naruszewicz do króla, 1794) KorNar 471;

Ośmielam się przedtożyć za nim prośbę moję (Hugo Kołłątaj do Tadeusza Czackiego, 1806) KołCzac 141.

\subsubsection{Inne warianty}

Wielka rozmaitość próśb, które starano się tak napisać, by niezwykłością wyrażenia zwrócić uwagę darczyńcy, nie pozwala na ich szczegółową klasyfikację. Oto niektóre przykłady:

Biore śmiałość proszenia Najlepszego Pana o taskę, żebyś raczył opatrzyć mnie z czym z garderoby swojej (sekretarz do Ignacego Potockiego, 1783) TKor 137 ;

Używam więc najgorętszych próśb do dobroczynnego JWMP Dobrodzieja serca, suplikujac o przyspieszenie przybycia Jego (starosta żmudzki do Ignacego Potockiego, 1787) KorPot 159;

Idę śmiele do Tronu Jego z prośba (Adam Naruszewicz do króla, 1788) KorNar 305;

Jest więc najusilniejsza prośba szkoty głównej, abyś... (Jan Śniadecki do prymasa, 1791) ŚniaLis 24;

Jeżeli JWPan Dobrodziej nagrodzisz tę ufności, w której ośmielam się przetożyć Mu interes stanu akademickiego [...] (Jan Śniadecki do Hugona Kołłątaja, 1791) ŚniaLis 12;

Poważam się udać z pokorna prośbq mojq do JW. Ministra i upraszać Go o wyjednanie mi łaski u Rzqdu (Mikołaj Chopin, 1829) ChopKor 88;

Udaje się do JW. P. hrabiny z uniżona prośbq o załatwienie tej bagatelki (lichwiarz, I poł. XIX w.) ŁozHis 93. 


\subsection{UWAGI KOŃCOWE}

$\mathrm{Z}$ zaprezentowanego przeglądu form wynika, że niektóre z nich występowały prawie wyłącznie w listach, jak np. suplikuję, upraszam, dopraszam się, życzytbym, śmiem prosić, dotyczy to także różnych konstrukcji analitycznych, natomiast nie było chyba takich, które występowały tylko w żywej mowie i do listów się nie przedostawały. Co prawda np. prośby typu mógłbyś z nim pomówić właściwe były rozmowom, ale wywodziły się jednak z dłuższych zdań dobrze zaświadczonych w epistolografii.

Wielokrotnie poza tym dało się zauważyć w przytoczonym materiale, że etykieta epistolarna oddziaływała na konwersacyjną. Tak można by interpretować opóźnienie niektórych formuł konwersacyjnych w stosunku do epistolarnych. $\mathrm{Z}$ opóźnieniem zaczęto stosować w żywej mowie formy pozwolisz, raczysz, prositbym, verbum + prośbę.

Proces odwrotny zachodził rzadziej, np. w wypadku emocjonalnych form typu zlituj się, które pojawiły się najpierw w wypowiedziach ustnych. 


\section{POLECENIA I ROZKAZY}

Akt polecenia, a w niektórych wypadkach także akt rozkazu, nie zawsze da się jasno oddzielić od aktu prośby, ponieważ formalne wykładniki tych aktów nieraz się pokrywają; np. Jędrzej Kitowicz pisał o rozkazie „w składzie prośby”, tzn. dostrzegał rozbieżność między mocą illokucyjną aktu a jego formą ${ }^{1}$. Toteż wyraźnej formalnej różnicy między rozkazem (poleceniem) a prośbą od dawna nie widziano.

W niniejszej pracy przyjęto kryterium autorytetu, w myśl którego z rozkazem lub poleceniem mamy do czynienia wtedy, gdy nadawca o pozycji dominującej zwraca się do odbiorcy znajdującego się w pozycji niższej, natomiast z prośbą wtedy, gdy nadawca o pozycji niższej zwraca do odbiorcy o pozycji dominującej lub gdy obaj są sobie równi. Dodatkowo bierze się pod uwagę inne czynniki pragmatyczne, jak np. możliwość zastosowania konkretnej sankcji wobec odbiorcy ${ }^{2}$.

Przy odróżnianiu polecenia od rozkazu, trzeba pamiętać, że jest ono stosunkowo nowe. Dziś przez rozkaz rozumie się „polecenie wykonania czegoś wydane przez osobę uprawnioną do tego lub mającą nad kimś jakąś przewagę..." ;"; dodajmy: polecenie wydane zwłaszcza w sytuacji takiej, gdy zwierzchnik zwraca się do podwładnego, przy czym obaj należą do organizacji ściśle sformalizowanej i zhierarchizowanej, typu wojsko czy policja. Jak wynika z tej definicji, polecenie to dziś pojęcie nadrzędne: „wypowiedź nakazująca komuś wykonanie jakiejś czynności”. Prośba z kolei to „uprzejme zwrócenie się do kogoś w celu uzyskania, wyjednania czegośt". W dawnej Polsce nie istniało rozgraniczenie między służbami „mundurowymi” a sferą „cywilną”, a pojęcie rozkazu obejmowało zarówno to, co nazywamy dziś rozkazami, jak i to, co nazywamy poleceniami.

Klasyfikacja jest tu taka sama jak klasyfikacja próśb (zob. 3.). Formy wyrażania rozkazu zostały uszeregowane od najprostszych do najbardziej skomplikowanych. Pozwoli to porównać obecność poszczególnych kategorii i ich frekwencję.

Nie wzięto pod uwagę specyficznych, ściśle sformalizowanych komend wojskowych typu otwórz panewkę, zamknij panewkę, do lewej nogi broń, ładunek $w$ rurę itp., bo nie należały one do powszechnie przestrzeganej etykiety językowej.

${ }^{1}$ M. Cybulski, Obyczaje językowe dawnych Polaków. Formuly werbalne w dobie średniopolskiej, Łódź 2003, s. 114.

${ }^{2}$ A. Awdiejew, Pragmatyczne podstawy interpretacji wypowiedzeń, Kraków 1987, s. 46-49, 128.

3 Stownik języka polskiego PWN, http://sjp.pwn.pl/rozkaz.

${ }^{4}$ Ibidem, http://sjp.pwn.pl/prośba. 


\subsection{CZASOWNIKI PERLOKUCYJNE}

\subsubsection{Formy trybu rozkazującego czasownika perlokucyjnego}

\subsubsection{W listach}

Do podwładnych pisano stosując najprostszy środek językowy oferowany przez system gramatyczny, a mianowicie 2. osobę trybu rozkazującego:

Więc na to obróć wszelkie starania i umiejętności swoje (król do Ksawerego Branickiego, 1768) KonfB 33;

WMPan Dobr widź się z Lelewelem (Jan Śniadecki do podwładnego, 1791) ŚniaLis 34;

Uważniejszym bqdź (hrabia do plenipotenta, 1856) KrasLis 171, Daj mi radę (1858) ib. 331.

Jako etykietalną obudowę stosowano formę adresatywną (zazwyczaj pan), formułę prośby lub inny składnik honoryfikatywny:

Zwijaj się pan na Mińsk (generał do generała, 1812) PamWoj 251;

Pisz Pan do mnie do Drezna (Zygmunt Krasiński do plenipotenta, 1852) KrasLis 45; Powiedz mi Pan także (1851) ib. 51; Pisz teraz Pan często do mnie (1854) ib. 88 ;

Donieś mi, proszę jak najrychlej (Hugo Kołłątaj do ekonoma, 1792) KołLis 15 ;

Staraj się Pan z łaski swojej, o ile można, na drobniejszego rozmiaru papierze pisywać do mnie (1851) ib. 33.

W XIX w. forma pan wymagała już prawdopodobnie 3. osoby czasownika:

Niech Pan list tu przyłączon odda natychmiast (1852) ib. 70, sim. ib. 110.

\subsubsection{W rozmowach}

Jest to forma stosowana zwłaszcza w typowych poleceniach wydawanych służbie oraz osobom podporządkowanym i (stale lub sytuacyjnie) zależnym:

Jak najprędzej wykonaj moje życzenie! (do sługi, ok. 1770) CzarKom 74;

Przeproś! (dama do młodego szlachcica II poł. XVIII w.) PamOch1, 217;

No idżże WPan na ratusz (Tadeusz Kościuszko do prezydenta Krakowa, 1794) PamOśm2, 9;

O, zmiarkujcie się, panie Ożarowski (król do hetmana, 1794) MagBac 115;

Proś panów jutro do mnie na obiad (do lokaja, kon. XVIII w.) BTP 94;

Niech mi okulbaczq konia (do lokaja, pocz. XIX w.) OlPam1, 51;

Zanieście go do mojego pokoju! (organista do chłopów, I poł. XIX w.) PamGal 269; 
Panie arendarzu, dajcie jeszcze kwartę na mnie (chłop do karczmarza, I poł. XIX w.) KraszU 75;

Weź te buty i zanieś za jegomością (do chłopca na posyłki, I poł. XIX w.) DzierzS 115;

No, gadajże, gdzieżeś to bywał (ojciec do syna, poł. XIX w. ) KraszDwa 88 ;

Każ dawać jeść (mąż do żony, poł. XIX w.) ŁozNoc 109;

Mów acan, co się święci i jak? (profesor do młodzieńca, poł. XIX w.) KraszSt 51 ;

Otwieraj, bo drzwi wyłamiemy (policjant do mieszczki, lata 60. XIX w.) KrasSt81; - i mnóstwo innych.

\subsection{2. , „żebyś..." + czasownik perlokucyjny}

Ten dobrze dziś znany sposób istniał już ponad 200 lat temu. Niewątpliwie wywodzi się on od zdań podrzędnych dopełnieniowych w konstrukcjach typu rozkazuję, żebyś...;

Żebyś mi ich nie uczył pisać! (baron do nauczyciela, I poł. XIX w.) PamGal 235.

\subsubsection{Formy czasu przyszlego czasownika perlokucyjnego}

Funkcja i obudowa formuł z użyciem futurum jest podobna jak w przypadku rozkaźnika.

\subsubsection{W listach}

Zechcesz oddać z laski swojej nieodwłocznie (profesor do podwładnego, 1791) ŚniaLis 31.

Opłatę za paszport weźmiesz pan prosto z mojej kasy [...] Nie zapomnisz też Pan przy tym wspomnieć urzędnikom KrasLis 48;

Będziesz Pan łaskaw [...] odnieść mu z mojej kasy 20.000 złp ib. 44.

\subsubsection{W rozmowach}

Pójdziesz WPan ze mną (kasztelan do guwernera, II poł. XVIII w.) SkarSegl 44;

Za podebraniem niniejszego rozkazu, wyprawisz podpułkownik wszelkie magazyny żywności (generał, 1812) PamWoj 234; 
Pani Rzemińska będzie tak dobra i wyegzaminuje Jadwisię z tego (pani domu do guwernantki, poł. XIX w.) DmNa 72;

Powiecie panu, gdy się zbudzi, że ja poszłam do kościoła (do służącej, lata 60 . XIX w.) KraszSt 78.

\subsubsection{Bezokolicznik czasownika perlokucyjnego}

Jest to forma swoista dla rozkazywania, nieużywana w prośbach, nieużywana też na piśmie:

Zaprzęać co żywo (do sług, II poł. XVIII w.) WójDw 161;

Janek albo Pietrze! Wziqć konie do stajni i dać obroku (pułkownik do sług, pocz. XIX w.) WójN 131;

Prosić natychmiast! (do lokaja, I poł. XIX w.) ŁozHis 65;

Okulbaczyć mi siwosza (oficer do stajennego, I poł. XIX w.) SkarbSt 39;

Tę sztukę perkalu odestać mojej żonie (ekonom do chłopa, poł. XIX w.) KraszJer 70;

Ustapić stąd natychmiast (rządca do chłopów, poł. XIX w.) KraszJary 98.

\subsection{5. „racz”, „chciej”, „pozwól”, „bądź laskaw” + czasownik per- lokucyjny}

Taka grzeczna forma polecenia czy rozkazu w ekscerpowanych tekstach jest bardzo rzadka.

\subsubsection{W listach}

Chciej z łaski swojej przypilnować, aby mi na pytania odpowiedziano (Ignacy Potocki do sekretarza KEN-u, 1774) KorPot 15;

Chciej WMPan naglić respons (Ignacy Potocki do sekretarza KEN-u, 1774) KorPot 17;

O moje zdrowie nie chciej się WP. turbować (Hugo Kołłątaj do ekonoma, 1793) KołLis 2, 43;

Chciej pan odpisać na ten piękny bilet (kasztelan do guwernera, 1798) SkarSegl 23;

Bądź też pan łaskaw mi pokrótce napisać (Zygmunt Krasiński do plenipotenta, 1851) KrasLis 33, sim. ib. 44, 54, 73, 98, $251 \mathrm{i}$ in.;

List tu przyłączony racz Pan oddać zaraz za przyjazdem memu Ojcu (Zygmunt Krasiński do plenipotenta, 1852) KrasLis 45;

Racz mi wyttumaczyć (Zygmunt Krasiński do plenipotenta, 1856) KrasLis 244, sim. ib. 239; 
Niech Pan będzie łaskaw i zapłaci rachunek (Elżbieta Krasińska do plenipotenta, 1854) KrasLis 258.

\subsubsection{W rozmowach}

Raczcie zachować moje wyznanie w tajemnicy (ks. Józef Poniatowski do oficerów, pocz. XIX w.) KoźPam1, 17;

Panie Szelechowski, pozwól siebie zapytać, na wielu moich lekcjach w tym roku być postanowiłeś (nauczyciel do ucznia, I poł. XIX w.) KozW 205.

Oznaką rozkazu była forma rozkaźnika czasownika perlokucyjnego:

A więc kochany kolego, badź łaskaw, oddaj jej to ode mnie (oficer do ułana, I poł. XIX w.) PamUł 136.

\subsection{6. „zmiłuj się" + tryb rozkazujący czasownika perlokucyjnego}

Tak ekspresywnej formy poprzedzającej polecenie prawie nigdy nie używano w listach:

Zmituj się, myślcie o sposobie na ten rok dla mnie niezawodnym (Hugo Kołłątaj do ekonoma, 1793) KołLis2, 72.

Była ona charakterystyczna dla polszczyzny mówionej, a konkretnie dla sytuacji, gdy na wykonaniu polecenia komuś bardzo zależało:

Helenko, zmiłuj się, schowaj jegomość pana Fircyka (do służącej, II poł. XVIII w.) CzarKom 103;

Zmituj się, przeprowadź i nie mów nikomu (biskup do kanonika, pocz. XIX w.) OpDz 46;

Krystyniuchno! Zmituj się nade mną! Bądź taka jak zawsze! (babka do wnuczki, pocz. XIX w.) DemS 153.

\subsection{CZASOWNIKI ILLOKUCYJNE}

\subsection{1. „rozkazuje"}

Poza kontekstami kancelaryjnymi (jak mandaty królewskie itp. ${ }^{5}$ ) ten podstawowy tu czasownik illokucyjny był stosowany jedynie w zupełnie wyjątkowych wypadkach, np.:

${ }^{5}$ Np. zalecam i przykazuje WPanu, abyś koniecznie zaraz zmienił dany Wittowi ordynans (król do hetmana, 1768) KonfB 174; sim. ib. 33. 
Rozkazuję całą powagą słusznie zagniewanego ojca, abyś nie tylko wybił sobie ten zamiar z głowy, ale nawet ażebyś mi i o nim więcej nie wspominał (ojciec w liście do syna, lata 30. XIX w.) SkarBTar 20.

\subsection{2. "proszę o", ,proszę" + gen., ,proszę, aby (żeby, by)”, ,proszę" + infinitivus}

\subsubsection{1. ,proszę o”, ,proszę” + gen.}

Był to m.in. zwyczajny sposób zamawiana usług:

Mości sekretarzu, proszę także $o$ czekoladę (szlachcic do „pocztmejstra”, II poł. XVIII w.) PamOch2, 6;

Proszę o klucze (urzędnik do czeladnika, II poł. XVIII w.) BDr 264;

Prosze fajki! (w kawiarni, lata 30. XIX w.) WójK 54;

Proszę o cygana (do bufetowej, lata 40. XIX w.) RusWar4, 75.

\subsubsection{2. ,proszę, aby”}

Była to rzadka forma wydawania poleceń. W listach stosowano niekiedy konwencjonalną obudowę charakterystyczną dla próśb, to jest okolicznik usilnie, a także formę adresatywną:

Usilnie Pana proszę, aby jej tam jak najwygodniej i najlepiej było (Elżbieta Krasińska do plenipotenta, 1854) KrasLis 259, sim. ib. 258, 90.

\subsection{W rozmowach}

Jednak proszę cię, żebyś się z nim nie widywała (rzemieślnik do wychowanicy, II poł. XVIII w.) BDr 189;

Prosze, aby ta pani miała dobre umieszczenie u jakiej przyzwoitej gospodyni (ks. Józef Poniatowski do oficera, pocz. XIX w.) KoźPam 27;

Proszę mościa, żebyś sobie zaprzagł i pojechał do miasta (starosta do porucznika, I poł. XIX w.) SkarbSt 38.

\subsubsection{3. ,proszę” + infinitivus czasownika perlokucyjnego}

Formuła rozkazu z użyciem formalnych wykładników prośby, inaczej niż w epoce średniopolskiej, dotyczyła niekoniecznie takich wypadków, gdy adresat polecenia mógł go nie wykonać, choćby ze względu na swą dość wysoką rangę ${ }^{6}$.

${ }^{6}$ M. Cybulski, Obyczaje językowe..., s. 165. 
W XVIII i XIX wieku stosowano ją bowiem także wobec osób o randze wyraźnie niższej. W ten sposób moc rozkazu (polecenia) słabła, przynajmniej formalnie, bo sytuacyjnie rozkaz pozostawał rozkazem.

\subsection{W listach}

O zdrowiu dzieci, jako też i ich powodzeniu informować mnie proszę (wojewoda do księdza, 1754) KKor 16;

Proszę wynaleźć mi dowód (król do Adama Naruszewicza, 1776) KorNar 57 ;

Proszę mi pomyślniejsze wieści donosić (Ignacy Potocki do sekretarza KEN-u, 1774) KorPot 12; sim. ib. 13, 14;

Proszę mi donieść (Hugo Kołłątaj do ekonoma, 1783) KołLis2, 47;

Proszę swoje doniesienia o sejmie kontynuować (profesor do podwładnego, 1788) ŚniaLis 11 ; sim. ib. 28, 33, 111, $184 \mathrm{i}$ in.;

Raporta regularnie co dwanaście godzin [...] zdawać proszę (generał do pułkownika, 1812) PamWoj 184; sim. ib. 207, 231;

Proszę mi to krótko i jasno wyttumaczyć (Zygmunt Krasiński do plenipotenta, 1854) KrasLis 82, sim. ib. 14, 155, 191, 199;

Proszę Cię być w aptece pana Heynrych (Zygmunt Krasiński do plenipotenta, 1858) KrasLis 300.

Mimo stosowania coraz grzeczniejszych form rozkazu trafiały się w listach Krasińskiego do plenipotenta kategoryczne sformułowania ujawniające ich rzeczywistą funkcję:

Do mamki Portowej list natychmiast proszę tu wyprawić KrasLis 41;

Proszę i obliguję rachunek mi z niej przysłać KrasLis 153.

\subsection{W rozmowach}

Ten sposób rozkazywania upowszechnił się dopiero w XIX wieku, można więc sądzić, że był przejawem wpływu etykiety epistolarnej na konwersacyjną. Im bliżej naszych czasów, tym więcej przykładów takiego grzecznego rozkazywania:

Proszę nigdy prośbą swoją mnie nie pokrzywdzać (król do Franiciszka Karpińskiego, kon. XVIII w.) KarpHis 132;

Panie kapitanie Radzikowski, proszę pamiętać o nich (podpułkownik, pocz. XIX w.) PamWit 73;

Proszę natychmiast udać się do swego pokoju (do uczennicy, pocz. XIX w.) OpDz 43;

Proszę mi powiedzieć, jak to się stało, że mąż wasz [...] sam się postawił w przykrym położeniu? (gubernator do szlachcianki, pocz. XIX w.) PamFel1, 70; 
Proszę bez zwłoki przejrzeć te kartki i zdać mi sprawę (Julian Niemcewicz do bibliotekarza, lata 20. XX w.) JanAu 136;

Proszę tak zrobić, jak mówiłem (pan do ekonoma, lata 40. XIX w.) KraszU 56;

Barona proszę dziś wyprawić! (do syna, poł. XIX w.) KraszDz 298;

Od tego czasu proszę mi zawsze pokazywać wszystko, co tylko pisać będziesz (matka do córki, poł. XIX w.) ŻmPow2, 78;

Prosze mi nie przerywać! (kardynał do szlachcica, poł. XIX w.) BujSt 307;

Prosze pisać, panie Chachełka (sędzia do sekretarza, poł. XIX w.) ŁozDw 316;

Jutro prosze przyjść z raportem (generał do urzędnika, lata 60. XIX w.) KraszSt 138;

Proszę no prędzej otwierać (policjant do mieszczki, lata 60. XIX w.) KrasSt 81;

Proszę się zapytać, czy mogę się z panią widzieć (szlachcic do sługi, lata 60. XIX w.) CieszP 291.

Zdarza się przysłówek bardzo, który zaostrzał zakaz:

Bardzo proszę, swoich trzech groszy nie wścibiać; inaczej będzie pokuta (zakonnica do panienki, pocz. XIX w.) OpDz 41;

Bardzo proszę swego nosa pilnować (szlachcianka do adwokata-Żyda, I poł. XIX w.) DzierzS 17.

4.2.2.4. ,proszę" + imperativus

\subsubsection{W listach}

Jest to bardzo rzadka forma w epistolografii. Jeśli się trafia, to $\mathrm{z}$ dodatkowymi sygnałami kategoryczności rozkazu:

Prosze Cię raz na zawsze, przestań tak ze mną czynić KrasLis 170;

Proszę Cię, drogi Panie Grodzki [...], natychmiast tam się zjaw ib. 240.

\subsection{W rozmowach}

Natomiast w żywej polszczyźnie taki sposób wydawania poleceń był zwyczajny:

Idź, proszę, i dowiedz się pewniej (szlachcic do sługi, poł. XVIII w.) BohK1, 170; Mówże mi, proszę (szlachcic do guwernera, poł. XVIII w.) BohK1, 178;

Prosze ciebie, nie pytaj mnie się (panna do służącej, ok. II poł. XVIII w.) CzarKom 90;

Moja lubko, proszę cię, zrób mi to (księżna do pokojówki, II poł. XVIII w.) PamRadz 176;

Proszę cię, nie przerywajże mi (szlachcic do służącej, II poł. XVIII w.) BDr 78;

Proszę, idź Panie, poszukaj go (Tadeusz Kościuszko do żołnierza, 1794) GrabWsp1, 62; 
Proszę cię, kochany Abe, porzuć te niewczesne żarty (matka do syna, przeł. XVIII/XIX w.) BykPan1, 263;

Julianie, proszę cię, badź przewodnikiem (szlachcic do sługi, pocz. XIX w.) ChodźKon 259;

Bądźże, proszę cię, u Nowosilcowa i oddaj mu wizytę (książę do szlachcica, pocz. XIX w.) KoźPam2, 344;

Prosze więc, nie stuchaj podłej rady służalców i każ zapłacić (książę do zięcia, pocz. XIX w.) KoźPam2, 170;

Usiądź panna proszę i chciej mi wszystko opowiedzieć (kupcowa do sklepikarki, lata 40. XIX w.) KuWar2, 208;

Mówcie, mówcie, proszę was (mieszczanin do chłopki, poł. XIX w.) KraszDz 203;

Proszę cię, moja Kasiu, nie nudź mię swojemi pytaniami (szlachcianka do służącej, poł. XIX w.) BujSt 245.

Przysłówek bardzo itp. w tej sytuacji prawie nie był używany:

Bądźże rozsądniejsza, moja Guciu, bardzo cię proszę (arystokratka do córki, poł. XIX w.) ŻmPow2, 72.

\subsubsection{Tryb przypuszczający: ,prosiłbym”, „,będę prosił”}

Zdarza się bardzo rzadko takie formułowanie polecenia:

Prositbym, abyś dotarł do Szałwijskiego i wręczył mu ten list (ojciec do syna, przeł. XVIII/XIX w.) BykPam 173;

Naprzód prositbym o papiery i wyjaśnienie stanu interesów bieżących (do rządcy, poł. XIX w.) KraszJary 73;

Bardzo będę pana prosit, żebyś temu nie sprzeciwiał (król do hrabiego, 1793) SchSt 82.

\subsection{3. ,życzę", ,żądam" i warianty}

Życzę, żebyś go dobrze przyjęła (ojciec do córki, kon. XVIII w.) CzarKom 384

$\dot{Z} y c z y t b y m$ nadto, aby nikt w domu o twym wyjeździe nie wiedział (szlachcic do syna, lata 30. XIX w.) RaRa 135;

Życzytbym udać się Jejmości do magazynu (przestępca do pomocnicy, lata 40. XIX w.) RusWar4, 37;

Żadam od ciebie jeszcze jednej usługi (szlachcianka do Żyda, I poł. XIX w.) KorzKol 178. 


\subsection{UWAGI KOŃCOWE}

Przegląd form służących do wydawania poleceń i rozkazów ujawnił tylko trzy sposoby specyficzne dla tego aktu mowy, to jest rozkazuję, bezokolicznik słowa perlokucyjnego i typ ,żebyś...” + czasownik perlokucyjny. Skoro zaś cała reszta form służyła też wyrażaniu próśb i z próśb się wywodziła, to należy wnioskować, że początek doby nowopolskiej jest okresem tendencji do „łagodzenia obyczajów".

Przejawiło się zatem zjawisko polegające na utożsamianiu funkcji różnych aktów etykiety, nie tylko w myśl zasady „twoja prośba jest dla mnie rozkazem”, ale i w myśl zasady mniej znanej: „mój rozkaz jest dla ciebie prośbą”. Stało się zatem istotne uwzględnianie godności i uczuć adresata rozkazu wydawanego w zwykłych okolicznościach towarzyskich. Być może widoczny jest tu wpływ sentymentalnej czułostkowości i romantycznego emocjonalizmu. 


\section{PRZEPROSINY}

Etymologicznie przeprosiny to jedna $\mathrm{z}$ odmian prośby: nadawca prosi odbiorcę o darowanie, zapomnienie winy ${ }^{1}$. Dziś formuły przeprosin należą do podstawowych aktów polskiej etykiety językowej ${ }^{2}$, ale jeszcze w dobie średniopolskiej używano ich rzadko i raczej niechętnie ${ }^{3}$. W okresie nowopolskim sytuacja ulega zmianie i frekwencja przeprosin zdecydowanie wzrasta zarówno w konwersacjach jak i w korespondencji. O ile w staropolszczyźnie ośrodkiem formuły były czasowniki przepuścić i odpuścić, a od XVII wieku także wybaczyć, to w badanym czasie zwycięża i dziś powszechnie stosowany performatyw przepraszam $^{4}$.

\section{1. „PRZEPRASZAM”}

Na podstawie zebranego materiału można stwierdzić, że już w pierwszym stuleciu doby nowopolskiej był to najbardziej konwencjonalny sposób proszenia o wybaczenie. Postać formuły zależała nie tylko od rangi nadawcy i odbiorcy, ale też od ciężaru przewinienia przepraszającego ${ }^{5}$. W przypadku spraw błahych wystarczał sam performatyw wzmocniony ewentualnie modyfikatorem przysłówkowym bardzo:

Bardzo przepraszam, mam jeszcze co pisać (szlachcic do marszałka w odpowiedzi na zaproszenie na śniadanie, II poł. XVIII w.) PamOch1, 386;

Przepraszam, omyliłem się (major do szlachcianki, kon. XVIII w.) PamGąs 229;

$\mathrm{O}$ ! przepraszam. Nie postrzegłem cię, Basiu (mąż do żony, I poł. XIX w.) FrDz1, 353;

Bardzo przepraszam, miałem owszem powody mniemać, iż walet w pańskim się ręku znajduje (szlachta podczas gry w karty, lata 40. XIX w.) OsP1, 63;

Przepraszam!... zapomniałem (szlachcic do prefekta, poł. XIX w.) ŁozCh2, 15;

${ }^{1}$ A. Wierzbicka tak eksplikuje akt przeprosin: ,wiem, że zrobiłem coś, co było dla ciebie złe / sądzę, że możesz czuć do mnie coś złego z tego powodu / mówię: żałuję, że to zrobiłem / mówię to, bo chcę, żebyś nie czuł do mnie nic złego". A. Wierzbicka, Genry mowy, [w:] Tekst i zdanie. Zbiór studiów, red. T. Dobrzyńska, E. Janus, Wrocław 1983, s. 130.

${ }^{2}$ E. Masłowska, Proszę, dziękuje, przepraszam, [w:] Język a kultura, t. 6, Wrocław 1992, s. $81-88$.

${ }^{3}$ M. Cybulski, Obyczaje językowe dawnych Polaków. Formuly werbalne w dobie średniopolskiej, Łódź 2003, s. 152.

${ }^{4} \mathrm{~W}$ dzisiejszym znaczeniu przepraszam pojawia się w polszczyźnie dopiero w drugiej połowie XVII w. Wcześniej był to termin z zakresu prawa. Ibidem, s. 156.

${ }^{5}$ M. Marcjanik, Polskie czasowniki adresatywne. Pragmatyka, semantyka, sktadnia, Kielce 1987, s. 40. 
Przepraszam, nie całkiem to pojmuję mocium dzieju (podczaszyc do rotmistrza, poł. XIX w.) BujSt 92;

Przepraszam, pilno. Żegnam pana (szlachcic do szambelana, poł. XVIII w.) BujSt 207;

Przepraszam przesłyszało mi się (szlachcic do rządcy, którego nazwisko przekręcił, poł. XIX w.) ŁozDw 240;

Przepraszam, już jestem zamówiona (szlachcianka na balu, poł. XIX w.) ŻmPow2, 20;

Przepraszam... nie wiedziałem (lekarz do pacjenta, poł. XIX w.) KraszSt 97 ;

Dzień dobry pani - i tysiąc razy przepraszam - może lekcya jeszcze nieskończona? (szambelan do baronowej, poł. XIX w.) BujSt 131.

Zwykle jednak stałym elementem formuły były biernikowe a rzadziej wołaczowe adresatywy:

Przepraszam, Podstolino, masz we mnie natręta (zalotnik, II poł. XVIII w.) ZabF 118;

Przepraszam pana, zostałam oszukana, myślałam już, że się gniewasz na mnie (szlachcianka do znajomego, II poł. XVIII w.) PamOch1, 325;

Przepraszam, panie majster (czeladnik do majstra, II poł. XVIII w.) BDr 183;

Przepraszam, panie bracie, nie będziesz tego wiedział (szlachcic do sługi, II poł. XVIII w.) BohK2, 355;

Przepraszam, mości dobrodzieju (szlachcic do gospodarza odmawiając dalszego picia, II poł. XVIII w.) BohK2, 366;

Przepraszam, nie pijam, tylko poncz (szlachcic odmawiając picia wina, II poł. XVIII w.) KK 173;

Przepraszam, mości dobrodzieju, pilny mam interes, zatrzymać się nie mogę (służący do pana, II poł. XVIII w.) CzarKom 144;

Przepraszam waćpana, wcale się nie mylę (szlachcic do znajomego, kon. XVIII w.) CzarKom 401;

Przepraszam pana, dawnoż pan dobrodziej złapał to piękne porównanie? (szlachcic przerywając drugiemu, pocz. XIX w.) ChodźKon 218;

Przepraszam bardzo pana hrabiego (lichwiarz, I poł. XIX w.) ŁozHis 72;

Przepraszam cię, przepraszam (szlachcic do służącej, którą przestraszył, I poł. XIX w.) FrDz1, 145;

Przepraszam pania, szukałem właściwie kogo innego (szlachta, poł. XIX w.) ŁozDw 264;

Przepraszam uniżenie pana dobrodzieja, nie uważałem (sędzia do szlachcica, poł. XIX w.) ŁozDw 194;

Przepraszam mój ojcze, nigdym w życiu nikomu nie nadskakiwał, o to możesz być najspokojniejszy (syn do rotmistrza, poł. XIX w.) BujSt 161;

Przepraszam pania, bardzo przepraszam, pozwoli pani na chwileczkę rozmowy (lekarz do guwernantki, poł. XIX w.) KraszDz 399; 
Przepraszam pana, natura co rok jest nowa (szlachcic do znajomego w dyskusji, poł. XIX w.) KraszDwa 384.

Większość zacytowanych powyżej aktów nie jest właściwymi przeprosinami ${ }^{6}$, tzn. wypowiadający je nie wyrażali żalu z powodu swego przewinienia. Formuły te były stosowane jedynie po to, by odbiorca nie myślał źle o nadawcy oraz aby podtrzymać atmosferę grzeczności ${ }^{7}$. Akty te są wyrazem świadomości przekraczania pewnych norm obyczajowych. Stopień szkodliwości takiego działania dla partnera interakcji jest jednak znikomy, bo dotyczy spraw mało istotnych (przerwania wypowiedzi, sprawienia niewielkiego kłopotu, niezgadzania się w jakiejś kwestii z rozmówca, spóźnienia itp.). Tego rodzaju formuły charakteryzują się także tym, że zwykle następują zaraz po przewinieniu lub nawet je poprzedzają (jak w przykładzie: Przepraszam, pilno. Żegnam pana. - nadawca przeprasza tutaj, że będzie musiał zakończyć rozmowę). W przypadku aktów przepraszania używanych w podstawowej dla nich funkcji byłoby to nieetyczne ${ }^{8}$.

Jeśli przewinienie było poważne, to formuła przeprosin miała zwykle bogatszą obudowę - dodawano okoliczniki zwiększające moc illokucyjną aktu lub reduplikowano czasownik:

Mościa dobrodziejko, przepraszam pokornie (szlachcic do matki narzeczonej, II poł. XVIII w.) KK 248;

Przepraszam dobrodzieja, przepraszam stokrotnie i pokornie, winienem jestem mea culpa, dobrodzieju (II poł. XVIII w.) ChodźPam 159 - tą wyjątkowo solenną formułą chciał przebłagać za stratowaną przez owce łąkę kwestarz szlachcica;

Przepraszam cię, przepraszam kochany panie Janie (starościna do Franciszka Salezego Dmochowskiego, I poł. XIX w.) DmochWsp 194;

Przepraszam cie serdecznie (starszy szlachcic do młodszego, I poł. XIX w.) SkarbSt 64;

Przepraszam pana jak najmocniej (dziennikarz do mieszczanina, poł. XIX w.) KuczGodz 12;

Nieskończenie przepraszam pana hrabiego (szlachcic, poł. XIX w.) ŁozDw 296.

Zebrany materiał prowadzi do wniosku, że formuły zawierające przepraszam były bardzo uniwersalne, właściwe zarówno w relacjach niesymetrycznych, jak i wtedy, gdy interlokutorzy mieli podobny status społeczny.

${ }^{6}$ M. Marcjanik, Grzeczność językowa..., s. 236. także M. Marcjanik, Funkcje komunikacyjne performatywu „przepraszam”, „Poradnik Językowy” 1995, z. 2, s. 22-30.

${ }^{7}$ A. Gałczyńska, Niedefinicyjne funkcje performatywu przepraszam, „Poradnik Językowy” 2002, z. 4, s. 16-24.

${ }^{8}$ Chociaż jak pisze M. Cybulski, wedle staropolskiej konwencji kat przed wykonaniem wyroku przepraszał swoją ofiarę. M. Cybulski, Obyczaje językowe..., s.153.

W badanym czasie tradycja ta musiała być nadal żywa, bo w jednym z ekscerpowanych tekstów znajdujemy takie przeprosiny „Przebacz waćpan niezgrabność” (FrDz1, 541) - miał zwrócić się kat do skazańca. 


\section{2. „PRZEPRASZAM ZA...”}

\subsubsection{W rozmowach}

Akty etykietalne z performatywem przepraszam mogły zawierać dopełnienie określające winę adresata, co wydłużało formułę i sprawiało, że była grzeczniejsza:

Jakże ja przepraszam panów za tak szkaradny obiad (wojewoda do gości, kon. XVIII w.) BłP 51;

Przepraszam waszmość panów za ich grubiaństwo (szlachcic przepraszając za zachowanie synów, II poł. XVIII w.) BohK1, 430;

Bardzo pana przepraszam za jego prostotę (burmistrz do szlachcica, przepraszając za zachowanie urzędnika miejskiego, II poł. XVIII w.) WybDr 381;

Przepraszam was za mojego kucharza (szlachcic do przyjaciół, poł. XIX w.) DmNa 46;

Przepraszam acana dobrodzieja za niego i za siebie (szlachcic do porucznika, I poł. XIX w.) SkarbSt 47;

Przepraszam za nieprzyzwoite obejście mojego kollegi (student do szlachcica, lata 20. XIX w.) PawEd 37;

Ja pana przepraszam [...] za niegrzeczne przyjęcie (szlachcianka do znajomego, lata 30. XIX w.) OrWęd 89;

Przepraszam panią Małgosię za mojego kolegę (mieszczanin do służącej, poł. XIX w.) ŻmPow1, 261;

Aleśmy tę nieprzyjemność, za którą barona przepraszamy, winni nieostrożności ojca (mieszczanin do barona, poł. XIX w.) KraszDz 53;

Przepraszam za poranną wizytę bez zameldowania (policjant do owocarki, poł. XIX w.) KraszSt 84.

\subsubsection{W listach}

Omawiany szablon był jednym z najchętniej stosowanych w ówczesnej korespondencji. W epistolografii akty przeprosin często miały konwencjonalny charakter ${ }^{9}$. Na początku listu zwykle przepraszano za długie zwlekanie z odpowiedzią:

Przepraszam za spóźnioną odpowiedź, bom był słaby (Hugo Kołłątaj do znajomego, 1792) KołLis1, 113;

Późno dopiero odpisuję na list Jego, otrzymany w odpowiedzi na odezwę moja, $z a$ co też najmocniej przepraszam (Wincenty Pol do znajomego, 1838) LisPol 28;

Niezmiernie Pana przepraszam za tak spóźnioną odpowiedź na list (literat do kolegi, 1842) KorGrab2, 113;

\footnotetext{
${ }^{9}$ A. Kałkowska, Struktura sktadniowa listu, Warszawa 1982, s. 57.
} 
Przepraszam cię bardzo za tak długie milczenie moje (Narcyza Żmichowska do przyjaciółki, 1860) ŻmLis2, 162.

Dla odmiany w subskrypcjach przepraszano za listy zbyt częste, długie, nudne, nabazgrane itp.:

$\mathrm{Z}$ najgłębszym respektem ścieląc się pod Stopy Pańskie, $z a$ nagłe pisanie, naprzykrzone i dłuższe niż przystoi, nieskończenie przepraszam (Stanisław Trembecki do księcia, 1802) TremNie 232;

Bardzo ciebie przepraszam za to pisanie (siostra stryjeczna do Adama Mickiewicza, 1821) KorFil 262;

Przepraszam jeszcze za nudy, których byłem przyczyną (Adam Mickiewicz do Marii Puttkamerowej, 1822) KorFil 285;

Po tysiąc razy przepraszam Panią za taką straszliwą bazgraninę (Adam Mickiewicz do hrabiny, 1830) KorMic 48;

Przepraszam za wszystko, com tylko mógł złego zrobić (mieszczanin w liście do brata, 1831) PamL 44;

Przepraszam panią za te nudne od początku do końca detale (lekarz do przyjaciółki, 1838) MorLis 28;

Przepraszam cię za okładanie mojemi listami (Seweryn Goszczyński do wydawcy, 1843) GoszLis 157;

Przepraszam cię na klęczkach za to niegodne serca Twojego pismo (oficjalista do przyjaciela, 1846) ChrzPam 203;

Przepraszam za ten list (Zygmunt Krasiński do znajomego, 1847) KrasSt 141;

Przepraszam Cię za list nieporządny (Józef Kraszewski do brata, 1859) KraszLis 414.

Epistolarne przeprosiny oczywiście nie zawsze miały tylko grzecznościowy charakter. Mogły dotyczyć bezpośrednio spraw omawianych w listach:

I teraz, i zawsze przepraszam, i przepraszać Cię będę za tyle trudów i kosztów (mieszczanin do brata, 1832) PamL 39;

Przepraszam Pana $z a$ te krytyczne lamentacje z powodu Pańskich wyjątków (literat do literata, 1842) KorGrab1, 81;

Przepraszam za tyle poleceń (Elżbieta Krasińska do plenipotenta, 1851) KrasLis 257.

\section{3. „PRZEPRASZAM, ŻE...”}

\subsubsection{W rozmowach}

Drugim sposobem opisania swojego przewinienia w formule przeprosin było dodanie po czasowniku performatywnym zdania podrzędnego dopełnieniowego z odrębną predykacją: 
Waszmość panów zaś przepraszamy, żeśmy im przeszkodzili (szlachta, II poł. XVIII w.) BohK1, 466;

Przepraszam, że wczora w wieczór nie mogłem upaść do nóg waszmość dobrodziki (szlachcic do wdowy, II poł. XVIII w.) BohK2, 38;

Przepraszam jako najpokorniej, że na moment odejść muszę (solenizant do gości, II poł. XVIII w.) KK 124;

Przepraszam panią, że się na moment oddalę (wojewodzic do baronowej, kon. XVIII w.) SkarSegl 176;

Panie chorąży, przepraszam, żem cię nieco obraził (ksiądz, kon. XVIII w.) RzewPam 241;

Mości panie starosto, najpokorniej przepraszam, że go tak długo zatrzymałem w miejscu tak nieprzyzwoitem dla jego godności (książę Radziwiłł, II poł. XVIII w.) RzewLis1, 136;

Przepraszam panią Wojewodzinę, żem jej od razu nie poznał (kapitan, pocz. XIX w.) WójN 186;

Przepraszam księżniczkę, żem wszczęła niemiłą rozmowę (szlachcianka, pocz. XIX w.) KuKas 156;

Przepraszam bardzo, że przeszkadzam (pisarz do cenzora, I poł. XIX w.) PamWoź 29;

Przepraszam cię, tatku, żem nic nie odpowiedziała (córka do szewca, I poł. XIX w.) DzierzS 43;

Przepraszam, sto razy przepraszam, kochany Hrabio, żem cię zatrzymała (szlachcianka, I poł. XIX w.) KorzDram 248;

Przepraszam pana pułkownika, żem dała na siebie czekać (szlachcianka, I poł. XIX w.) KorzDz 39;

Przepraszam Pana Grafa, że na pańskim gruncie chciałem polować (hrabia, lata 20. XIX w.) OlPam1, 159;

Przepraszam pana, że mu przerywam (mieszczanin do podwładnego, lata 40. XIX w.) RusWar3, 64;

Przepraszam, że nie składam roboty, bo mam pilno wykończyć (modystka do znajomego, lata 40. XIX w.) RusWar2, 151;

Przepraszam pana, że nadużywam jego uprzejmości (szlachta, poł. XIX w.) CieszP 127;

Przepraszam pana bardzo, przepraszam, że się mięszam nie w swoję rzecz (szlachcianka do syna plenipotenta, poł. XIX w.) KraszH 234.

\subsubsection{W listach}

W epistolografii ten typ przeprosin również był często stosowany. Przeważają użycia w korespondencji między osobami o porównywalnym statusie społecznym, choć w ten sposób przepraszano i wyższych rangą. Formuły pisemne są 
bardzo podobne do ustnych, obudowa etykietalna ogranicza się do formuł adresatywnych i okoliczników:

Przepraszam Panią, że tu przyłączam bilecik dla JMPana Skuratowskiego (Franciszek Karpiński do znajomej, 1775) KarpKor 1775;

Ja pięknie przepraszam, że się nie udałem z tym interesem do Jaśnie Pana Excellencji jenerała (lichwiarz do hrabiny, I poł. XIX w.) ŁozHis 93;

Przepraszam, że Pana tą bazgraniną zatrudniam (Euzebiusz Słowacki do generała, 1812) LisRS 24;

Przepraszam bardzo Pana Tomasza, że go nudzę moją bazgraniną bez sensu (Maria Puttkamerowa do Tomasza Zana, 1822) KorFil 270;

Przepraszam Pana, że go obarczam tak marudnymi zleceniami (Salomea Słowacka do Antoniego Odyńca, 1826) LisRS 145;

Przepraszam, że z taką konfidencyją zaczynam (Wincenty Pol do znajomego, 1837) LisPol 24;

Przepraszam Pana Hrabiego, że tak późno odpisuję na szacowny list (literat w liście do hrabiego, 1842) KorGrab2, 61;

Przepraszam cię raz jeszcze, żem się do Ciebie zapędził z tą prośbą (Wincenty Pol do przyjaciela, 1843) LisPol 104;

Przepraszam cię, szanowny ziomku, że nie będę mógł zrobić zadość twemu żądaniu (Seweryn Goszczyński do znajomego z kręgu Towiańskiego, 1843) GoszLis 162;

Przepraszam Panią że tak późno dziękuję i łaję za piękne a niepotrzebne kwiatki (Fryderyk Chopin do znajomej, 1845) ChopKor2, 128.

\section{4. „PRZEPRASZAM, ALE...”}

Nieco inny typ aktów przeprosin prezentują zdania, w których po czasowniku performatywnym pojawia się wypowiedzenie pozornie współrzędne przeciwstawne (a w rzeczywistości podrzędne dopełnieniowe) ${ }^{10}$, a w nim informacja o przewinieniu, która jest jednocześnie próbą usprawiedliwienia ${ }^{11}$. W ekscerpowanych tekstach formuły takie pojawiają się dopiero około połowy XIX w.:

Przepraszam cię, moja ciociu, ale ja zawsze parafianka (kasztelanka do starościny, I poł. XIX w.) KorzKom 161;

${ }^{10}$ M. Marcjanik, Grzeczność językowa..., s. 239.

${ }^{11}$ Wśród formuł utworzonych według tego schematu znajdują się także akty, w których performatyw przepraszam pełni funkcję prośby. Nadawca oczekuje od odbiorcy pewnego zachowania i z góry przeprasza go za ewentualny dyskomfort:

Przepraszam pana, ale czemuś pan nie siadasz i nie zaczynasz nareszcie? (szlachcic do sędziego, poł. XIX w.) ŁozDw 155 - jest to w istocie prośba o konkretne działanie odbiorcy;

Przepraszam, ale ja tego nie rozumiem (Żyd do szlachcica, lata 40. XIX w.) DzierzDz 86 nadawca prosi o wyjaśnienie. 
Przepraszam jegomości, ale tak jestem zirytowany, że o wszystkiem zapomniałem (kapitan do księdza, poł. XIX w.) ŁozHis 89;

Najmocniej przepraszam państwa, ale $\mathrm{w}$ istocie godziny mam policzone (lekarz do rządców, poł. XIX w.) KraszJary 73;

Bardzo pana dobrodzieja przepraszam, ale nie wiedziałem (rządca do lekarza, poł. XIX w.) KraszJary 71;

Przepraszam, wstałem rano, alem miał do pisania (szlachcic do baronowej, poł. XIX w.) BujSt 77;

Przepraszam cię, ale cała myśl moja zajęta była pisaniem (szlachcic do przyjaciela, poł. XIX w.) CieszP 244;

Przepraszam panią, ale ja zaraz powrócę (panienka do guwernantki, poł. XIX w.) DmNa 188;

Przepraszam cię, kochany Auguście, ale jeszcze i tego nie widzę (szlachcic do przyjaciela, poł. XIX w.) KorzDram 327;

Przepraszam was z całego serca, ale dziś tak jakoś nie jestem w humorze (referendarz do znajomych, poł. XIX w.) KorzRep 90;

Przepraszam jegomości, ale muszę profitować z każdej chwili ażeby zrobić porządek (służący do mieszczanina, poł. XIX w.) KuczGodz 34.

W ekscerpowanej korespondencji omawiane tu przeprosiny w zasadzie nie występują. Jedynie raz spotykamy taką formułę w liście Michała Grabowskiego do znajomego literata, z którego poglądami nie zgadzał się:

Przepraszam Pana, ale ja, który znam lud wiejski z blizka, wiem, że on nie ma za „niesprawiedliwość” czynszu i roboty (1842) KorGrab2, 111-112.

W całym badanym okresie w konwersacjach pojawiają się również bardziej rozbudowane akty, w których najpierw podaje się informację o przewinieniu za pomocą schematu przepraszam za lub przepraszam, że, a zdanie przeciwstawne zawiera jedynie usprawiedliwienie:

Przepraszam waści, panie Bartłomieju, że przerywam modlitwę, ale musim pomówić ze sobą (hetman do zubożałego szlachcica, II poł. XVIII w.) WójDw 21;

Przepraszam za spóźnione odwiedziny, ale mam do pomówienia z waszą książęcą mością (książę do żony, kon. XVIII w.) BolBez1, 155;

Przepraszam cię, hrabino, że tak wcześnie cię zaprosiłem na śniadanie, ale miałem sny męczące (mąż do żony, pocz. XIX w.) WójN 238;

Mościwa pani, wielce przepraszam za moję klaczkę, ale Pan Bóg mi świadkiem, że to z przypadku (szlachcic, którego koń stratował stoisko warszawskiej przekupki, pocz. XIX w.) WójSp 213;

Przepraszam, że śmiem przeciwić się pani, ale zjawisko moje było tak jawne i rzeczywiste (szlachcic do hrabianki, poł. XIX w.) ŁozDw 137.

$\mathrm{Z}$ badanego materiału wynika, że użycie takich formuł zależało nie tyle od rang nadawcy i odbiorcy, co od konkretnej sytuacji komunikacyjnej. Szlachcic, który wyrządził przekupce dużą szkodę przeprasza ją równie solennie jak hrabia żonę. Akty te z racji swojej długości miały dużą moc illokucyjną. 


\section{5. „PRZEPRASZAM, JEŚLI...”ITP.}

Formuły przeprosin, w których po performatywie występuje zdanie podrzędne okolicznikowe warunku są używane w sytuacji, gdy nadawca tego aktu nie jest przekonany, że zrobił coś złego. Taka strategia grzecznościowa ma za zadanie zaspokoić potrzeby adresata i zapobiec ewentualnemu zakłóceniu zgody między partnerami interakcji. W badanym okresie akty tego rodzaju są rzadko spotykane w rozmowach i w listach:

Przepraszam waszmość pana, jeśli w czym przeciwko godności jego moi kochani sąsiedzi wykroczyli (szlachcic do dziennikarza, II poł. XVIII w.) BohK2, 312;

Przepraszam jaśnie wielmożnego pana, jeżelim to zrobił (chłop do szlachcica, I poł. XIX w.) KorzKol 106;

Moje dziecię, przepraszam, jeżelim cię tem pytaniem boleśnie dotknęła (matka do córki, pocz. XIX w.) WójN 176;

Najuniżeniej przepraszam panią, jeżeli jej to zrobiło przykrość (wojewodzic do starościny, I poł. XIX w.) KorzKom 180;

Jeślim cię w czem obraziła, to przepraszam jak najpokorniej (szlachcianka do przyjaciółki, 1840) HoffKryst 204;

Przepraszam, jeśli zanadto wymagam (Seweryn Goszczyński do wydawcy, 1842) GoszLis 151.

\section{6. „DARUJ”/'DARUJESZ” I PRZEKSZTAŁCENIA}

\subsubsection{W rozmowach}

Powszechnie stosowano także pośrednie akty przeprosin ${ }^{12}$. Najczęściej są to formuły zawierające czasownik darować, które zaczęły pojawiać się dopiero w pierwszym stuleciu nowopolszczyzny - ich użycie nie zostało poświadczone w dobie średniopolskiej ${ }^{13}$. Frekwencja tego rodzaju próśb o wybaczenie jest wysoka w całym badanym okresie. Akty te funkcjonowały podobnie jak frazy z performatywem przepraszam: stosowano je jako przeprosiny właściwe, gdy wyrażano autentyczny żal z powodu poważnego przewinienia, ale również w przypadku spraw bardzo błahych. Swoim zasięgiem objęły wszystkie stany: przepraszał w ten sposób chłop pana i dworzanin króla. Najczęściej formuła miała postać trybu rozkazującego:

Lecz daruj W. K. Mość, przebacz żalowi... ale książę Prymas był zdrajcą i powinien skończyć na rusztowaniu (dworzanin do Stanisława Augusta Poniatowskiego, II poł. XVIII w.) MajerKron 79;

\footnotetext{
${ }_{12}$ M. Marcjanik, Grzeczność językowa..., s. 223.

${ }^{13}$ M. Cybulski, Obyczaje językowe..., s. 152-157.
} 
Więcej, daruj pani, powiedzieć nie mogę (szlachcic do podkomorzanki, II poł. XVIII w.) PamOch1, 397;

Daruj mi waszmość pan dobrodziej to głupstwo moje (młodszy szlachcic do starszego, II poł. XVIII w.) BohK2, 172;

Daruj, dobra Malwino, że czułe twoje serce trwożę (szlachta, II poł. XVIII w.) WirMal 127;

Daruj, daruj, panie (starościc do baroneta, II poł. XVIII w.) WybDr 216;

Daruj mi, niesłusznie cię posądziłem, żono (szlachta, II poł. XVIII w.) ZabF 128;

Daruj, żeć prawdę mówię, choć żeś starościcem (szlachta, II poł. XVIII w.) WybDr 91;

No, darujzes mi, Dosiu (młynarz do żony, kon. XVIII w.) BoCu 153;

Daruj, zacny wojowniku, że cię zapytam (zakonnik do oficera, pocz. XIX w.) ChodźPam 245;

Daruj mi mój przyjacielu, że cię zapytam, kogożeś to pochował? (mieszczanie, pocz. XIX w.) WójSp 127;

Daruj mi, zacny starcze, żem tak późno wezwać cię śmiała (kasztelanowa do urzędnika, I poł. XIX w.) KorzDram 127;

Daruj mi, kochaneczku. Nie chciałam cię rozgniewać (chłopka do męża, I poł. XIX w.) KorzKom 8;

Daruj mi, Aronie, i pomóż (komornik do Żyda, I poł. XIX w.) KorzKom 98;

Daruj, ojcze! nie mogłem być posłusznym (szlachcic, I poł. XIX w.) KorzKol 137;

Daruj, jeżeliśmy się poważyli prosić cię, abyś panie stanął na chwilę u tego grobu (uboga szlachcianka do starościca, I poł. XIX w.) SkarbDod 103;

Daruj mi, jeśli śmiałem przypuścić do głowy myśl starania się o siostrzenicę twoję (szlachta, I poł. XIX w.) SkarbSt 63;

Daruj, naczelny wodzu, że tej łaski nie przyjmę (marszałek do Jana Zygmunta Skrzyneckiego, lata 30. XIX w.) ZałWsp 380;

Daruj mi, żem tak się ubrała (szlachcianka do znajomej, I poł. XIX w.) KorzDram 372;

Daruj pani otwartości mojej (szlachcic do znajomej, lata 40. XIX w.) DzierzD1, 117;

Daruj szanowny redaktorze, ale też to było wielką z Twej strony naiwnością, odwoływać się do sumienia pp. redaktorów Jutrzenki (czytelnik do dziennikarza, lata 40. XIX w.) KorKrak 10;

Darujcie, darujcie dobrodzieju (chłop do pana, lata 40. XIX w.) DzierzD2, 78;

Daruj mi pan, zapewne obraziłam go (córka ślusarza do artysty, poł. XIX w.) ŻmiPow1, 323;

Zasmuciłem cię, życie moje, daruj mi (mąż do żony, pocz. XIX w.) PamFel1, 34;

Daruj, że w takiej chwili odchodzę (córka profesora do owocarki, poł. XIX w.) KraszSt 107. 
Chociaż akty te zawierają tryb rozkazujący właściwy dla relacji z osobami, z którymi jesteśmy „na ty”, a więc prezentujący najniższy poziom honoryfikatywności ${ }^{14}$, to zebrany materiał pokazuje, że były to formuły bardzo uniwersalne. Stosowano je nie tylko wówczas, gdy partnerzy interakcji mieli podobne rangi pragmatyczne, ale i w sytuacji, gdy status społeczny nadawcy był różny od statusu odbiorcy. Na rodzaj relacji między przepraszającym a przepraszanym wskazują formy adresatywne - często poufałemu rozkaźnikowi drugiej osoby towarzyszy trzecioosobowa tytulatura standardowa pan, pani. Sposobem na zwiększanie mocy illokucyjnej takich formuł, szczególnie w relacji podrzędno-nadrzędnej, było dodawanie wieloskładnikowych adresatywów i form atrybutywnych pozytywie wartościujących odbiorcę.

Akty $\mathrm{z}$ analityczną formą trybu rozkazującego lub z honoryfikatywnym czasownikiem raczyć, które prezentują wyższy stopień grzeczności są w badanym materiale rzadkością:

Niech pani daruje (hrabia do szlachcianki, I poł. XIX w.) KorzKom 352;

Racz jaśnie wielmożny pan darować (służąca do hrabiego, I poł. XIX w.) KorzDram 270;

Jaśnie wielmożny panie, racz darować staremu nieuważne słowo (komornik do hrabiego, I poł. XIX w.) KorzKom 43;

Jaśnie oświecona pani, racz mi darować moją śmiałość (komornik do księżniczki, I poł. XIX w.) KorzKom 99;

Niechże mi najłaskawszy sąsiad daruje (szlachcic, poł. XIX w.) KraszH 88;

Niech mi panie daruja (mieszczanin do hrabianek, poł. XIX w.) KraszDz 212.

Drugim rozpowszechnionym typem przeprosin były formuły, w których człon werbalny miał postać trybu oznajmującego:

Darujesz mi waszmość pan, że nie będąc znajomym przerywam jego zabawy (starosta do szlachcica, II poł. XVIII w.) BohK2, 404;

Darujesz mi, waćpani, jeżeli mam swoje [sekrety] (podstolina do siostry, II poł. XVIII w.) ZabF 85;

Darujesz mi waćpan, że go teraz porzucić muszę (służąca do szlachcica, kon. XVIII w.) CzarKom 376;

Darujcie mi, moi drodzy goście, że was zostawię na chwilę (chorążyna, I poł. XIX w.) KorzKom 113;

Darujesz mi pewnie, żem posłała do ciebie i prosiła cię, abyś przyszedł (generałowa do pułkownika, I poł. XIX w.) KorzWd 10;

Przykro mi to bardzo, ale pan hrabia daruje (lichwiarz, I poł. XIX w.) ŁozHis 74;

Darujesz pani (regent do szlachcianki, lata 40. XIX w.) RusWar2, 127;

Pan dobrodziej daruje, że ośmielam się jeszcze naprzykrzać panu dobrodziejowi (sędzia do szlachcica, poł. XIX w.) ŁozDw 357;

${ }^{14}$ R. Huszcza, Honoryfikatywność. Gramatyka. Pragmatyka. Typologia, Warszawa 2006, s. 172. 
Darujesz mi prezesie, że się mięszam do tego (bratowa do szwagra, poł. XIX w.) KraszDwa 184;

Daruja panie, że tak natrętnie przerywamy im wypoczynek (baron do hrabianek, poł. XIX w.) KraszDz 71;

Darujesz mi doktorze, że może nie we właściwej godzinie przybywam (mieszczanin do lekarza, poł. XIX w.) KraszDz 104;

Darujesz mi pan, że go opuszczę (córka plenipotenta do starościca, poł. XIX w.) KraszH 192;

Daruje pani, że jej odmówić muszę (lekarz do żony rządcy, poł. XIX w.) KraszJary 74 ;

Profesor mi daruje, że tak jestem natrętnym (mieszczanin, lata 60. XIX w.) KraszSt 47.

Podobnie jak w przypadku formuł z rozkaźnikiem, często drugiej osobie czasownika towarzyszy tytulatura właściwa dla osoby trzeciej, wskazująca na dystans między nadawcą a odbiorcą. Pośrednie akty przeprosin występują w takich samych typach struktur składniowych jak te z performatywem przepraszam. Najczęściej po formule zawierającej różne postaci czasownika darować następuje zdanie podrzędne dopełnieniowe, w którym wyjaśniany jest powód przeprosin.

Bardzo rzadko spotykanym przekształceniem omawianych fraz są akty, które zawierają formalne wykładniki prośby, co zwiększa ich moc illokucyjną:

Proszę darować tę mitręgę, księże kwestarzu dobrodzieju (szlachcic, II poł. XVIII w.) ChodźPam 161;

Proszę mi darować, jeżeli nie wiedząc gdzie mi kwaterę przeznaczono, zajechałem wprost do dworu (szlachcic do gospodarza, lata 40. XIX w.) DzierzD2, 210;

Kochana matuniu, proszę mi darować (szlachcic do matki, poł. XIX w.) KraszDwa 284.

\subsubsection{W listach}

W początkach doby nowopolskiej akty przeprosin z czasownikiem darować zaczynają się pojawiać nie tylko w konwersacjach, ale również w epistolografii. Sposób ich używania jest bardzo zbliżony do tego co obserwujemy w rozmowach: występują podobne struktury składniowe i elementy etykietalnej obudowy. Właściwy tylko dla listów zabieg mający na celu zwiększenie grzeczności przeprosin, to dodawanie po daruj czasownika performatywnego proszę. Podobnie jak w kontaktach ustnych zdecydowanie największą frekwencję miały formuły z członem werbalnym w postaci rozkaźnika:

Daruj mi WKMść jeżeli ten Rapport nie jest tak dokładny jakem zwykł czynić WKMci (Ksawery Branicki do Stanisława Augusta Poniatowskiego, 1768) KonFB 121; 
Daruj, JW Panie, że tak śmiało mówię, gdyż żal uwagi nie ma (nauczyciel do Ignacego Potockiego, 1787) KorPot 160;

Daruj proszę mojej śmiałości (Hugo Kołłątaj do znajomego, 1792) KołLis1, 64 ;

Daruj JWW Pan mej ufności, która sprawia, że go utrudzam (Hugo Kołłąaj do podkanclerzego litewskiego, 1792) KołLis1, 1792;

Daruj mi, proszę, żem nie wspomniał o moim zdrowiu (arystokrata do starościny, 1792) SzymLis 22;

Daruj, Panie, że się tak wypisuję (sekretarz do Ignacego Potockiego, 1793) TKor 183;

Daruj mi, pani moja, że dotychczas nie pisałem do Ciebie (arystokrata do starościanki, 1794) SzymLis 41;

Daruj JW. Pan, że tak wiele piszę (Hugo Kołłątaj do Tadeusza Czackiego, 1806) KołCzac 134;

Jeżelim ci stał się może rozwlekły i niezrozumiały, daruj, bo zwłaszcza dziś lepiej pisać nie mogę (Adam Mickiewicz do przyjaciela, 1817) KorFil 19;

Daruj mi, że się tak otwarcie tłumaczę (Jan Czeczot do Adama Mickiewicza, 1819) KorFil 22;

Daruj, Józefie, że nie piszę więcej (Teofil Januszewski do przyjaciela, 1829) LisRS 385;

Daruj JWM Pani Dobrodziejka staremu gawędzie, że ją tak długo nudzę (Jan Śniadecki do hrabiny, 1830) ŚniLis 203;

Darujcie mi, że nic pocieszającego o sobie donieść nie mogę (Fryderyk Chopin do rodziny, 1831) ChopKor1, 174;

Daruj, że się powtarzam, daruj, że cię może nudzę (Zygmunt Krasiński do przyjaciela, 1838) KrasJar 18;

Daruj mi, przebacz mi, że tak wybucham rozpacznemi jęki (Zygmunt Krasiński do ukochanej, I poł. XIX w.) KrasDel 43;

Daruj, że tak zwlokłem przesłanie ci szczegółów o Konarskim (Seweryn Goszczyński do przyjaciela, 1841) GoszLis 129;

Daruj, jeźli słabo i nędznie wyrażać się będę (Zygmunt Krasiński do Juliusza Słowackiego, 1843) KrasSł 41;

Daruj, Pani, mazaniom i niezgrabnościom (lekarz do przyjaciółki, 1849) MorLis 149;

Daruj mi, Pani, że tak wiele mówię o sobie (Adam Pług do Pauliny Wilkońskiej, 1857) WilkWsp 291;

Daruj, serdeczny Panie Józefie, że nie uprzedziwszy Cię, poważyłem się ofiarować Ci wiersz mój nowy (Teofil Lenartowicz do Józefa Kraszewskiego, 1858) LenarKor 23.

Badany materiał pokazuje, że formuł tych używano przede wszystkim w korespondencji do osób o podobnym statusie społecznym do nadawcy, ale możliwe było także ich zastosowanie w relacjach asymetrycznych - nawet do króla. 
Dobrze poświadczone w ekscerpowanej epistolografii są też frazy z czasownikiem w trybie orzekającym:

Darujesz mi to JWW Pan, że podobieństwa użyłem dlatego, ażebym jaśniej myśl może wytłumaczył (podkomorzy litewski do Andrzeja Zamoyskiego, II poł. XVIII w.) WybŻ 341;

Darujesz WKMść moją prostotę przez wzgląd moich szczerych chęci (Ksawery Branicki do Stanisława Augusta Poniatowskiego, 1768) KonFB 146;

Darujesz Pani, że to co odjąłem powinności służenia Jej dnia dzisiejszego, dałem potrzebnemu gwałtownie wczasu memu (Franciszek Karpiński do znajomej, 1777) KarpKor 13;

Darujesz mi JWPDobrodziej i za natrętność grubiańską nie racz poczytać słudze swemu, że przez najgodniejsze ręce Jego śle powtórny już memoriał do j.o. Komisji Edukacji Narodowej (prefekt szkolny do Ignacego Potockiego, 1780) KorPot 91;

Darujesz JWMPDobrodziej [...] że powtórną inkomoduję ekspedycją (starosta żmudzki do Ignacego Potockiego, 1787) KorPot 159;

Darujesz JOWKM, że od czasu mego wyjazdu, sytuacja interesów Ojczyzny nie pozwalała mi pisać do Tych, których najwięcej szanowałem (Hugo Kołłątaj do księcia biskupa krakowskiego, 1793) KołLis2, 37;

Daruje mi Pani, że Jej z wiadomości publicznych nic nie donoszę (arystokrata do starościny, 1794) SzymLis 71;

Darujesz, Obywatelu Naczelniku, iż śmiem ci przypomnieć oddanie tego listu (Karol Kniaziewicz do Tadeusza Kościuszki, 1800) LisKn 27;

Darujesz W.Pan, że mu dalszych tomów tego dzieła przesłać nie mogę (Hugo Kołłątaj do współpracownika, 1806) KołCzac 121;

Darujesz tedy, że tylko słów kilka do ciebie załączę (Adam Mickiewicz do przyjaciela, 1826) KorMic 11;

Darujesz, czcigodna Pani, iż do niej wprost się udaję (znajomy do Klementyny Hoffmanowej, 1841) TrenLis 55.

Dwa prezentowane powyżej typy formuł zdecydowanie dominują w analizowanych listach. Ewentualne przekształcenia są rzadkie:

Raczysz WKMć łaskawie darować śmiałość wyrazów moich (Ignacy Krasicki do Stanisława Augusta Poniatowskiego, 1781) KKor2, 31;

Proszę mi darować, że przyłączam drugi [list] do Święcickiego (arystokrata w liście do starościny, 1792) SzymLis 29;

Niech Pan daruje, aleśmy się śmieli z nich i z Pana (Salomea Słowacka do Antoniego Odyńca, 1827) LisRS 179;

Jeśli w czem błądzę, racz mi łaskawie darować (Zygmunt Krasiński do Kajetana Koźmiana, 1844) KrasSł 112.

Obudowanie aktu przeprosin czasownikiem honoryfikatywnym raczyć, wprowadzenie formalnych wykładników prośby oraz okolicznika łaskawie miało na celu zwiększenie mocy illokucyjnej aktu. 


\section{7. „WYBACZ/PRZEBACZ”, „WYBACZYSZ/PRZEBACZYSZ” I PRZEKSZTAŁCENIA}

\subsubsection{W rozmowach}

Formuły te są dość nowe, pojawiają się w polszczyźnie dopiero od XVII wieku. W początkach doby nowopolskiej zaczęły być wypierane przez akty z performatywem przepraszam, ale nadal ich frekwencja $\mathrm{w}$ badanych tekstach jest wysoka. Częstotliwość występowania wybaczyć i przebaczyć jest porównywalna. Struktury składniowe następujące po omawianych czasownikach są takie same jak w przypadku przepraszam i daruj. Zdecydowanie dominującą postacią członu werbalnego jest rozkaźnik. W ten sposób przepraszano przede wszystkim osoby, które zajmowały podobne miejsce w hierarchii społecznej jak nadawca:

Wybacz, mój kochany, niecierpliwości mojej, nie ja to czasem wydziwiam, ale moja rozpacz (szlachcic do przyjaciela, II poł. XVIII w.) KK 302;

Przebacz, wspominając, że uczucia moje w każdym czasie i w najmniej pospolitych zdarzeniach tobie jednemu poświęcone były (szlachcianka do ukochanego, II poł. XVIII w.) WirMal 165;

Przebaczcie, moja śliczna (chłop do znajomej, II poł. XVIII w.) BohK2, 280;

Wybacz, proszę (mąż do żony, II poł. XVIII w.) WybDr 108;

Synu, wybacz mi, żem cię niesłusznie martwił (szlachcic, II poł. XVIII w.) BohK1, 210;

Wybaczże mi, moja Hortensjo (szlachcic do córki, II poł. XIX w.) CzarKom 271;

Wybacz waćpanna dobrodziejka, jeżelim trochę żywo mówił (kawaler do panny, II poł. XVIII w.) CzarKom 1770;

Wybaczaj bracie, ale tak postępując, trudno poczciwych przekonać (szlachcic do brata, II poł. XVIII w.) RzewLis1, 109;

Zatem przebacz mi, reverendissime, jeżelim cię nie chcąc obraził (zakonnik do plebana, II poł. XVIII w.) ChodźPam 167;

Wybaczaj, panie chorąży, ale gdzież nam córkę zawieziesz? (rodzice do narzeczonego, kon. XVIII w.) RzewPam 118;

Wybaczcie matko droga, że dwa razy w życiu sprzeciwiłem się waszej woli (szlachcic, przełom XVIII/XIX w.) BykPam2, 36;

Wybacz mej otwartości, ale twój ojciec jest stare dziecko (szlachcic do narzeczonego córki, przełom XVIII/XIX w.) BykPam2, 193;

Kochany Józefie! przebacz, zapomnij co się działo (major do kapelana, I poł. XIX w.) FrDz1, 309;

Przebacz mi, proszę, żem twoję delikatność obraził (starosta do szlachcica, I poł. XIX w.) SkarbSt 64;

Wybacz mi pan [...] że nieprzyjąłem pana tak jakbym był rad przyjać (szlachcic do cześnika, lata 20. XIX w.) OlPam1, 331; 
Przebacz, przebacz Heleno (szlachcianka do przyjaciółki, lata 40. XIX w.) PrusMor 103;

Przebacz żem ciebie posądzał (lichwiarz do syna, lata 40. XIX w.) RusWar4, 176;

Wybacz mi ojcze, lecz mam pilny interes (szlachta, lata 40. XIX w.) RusWar2, 168;

Przebacz Konstancyo (szlachcic do szlachcianki, lata 40. XIX w.) DzierzD1, 116;

Przebacz pani, szukałem cię tu (szlachcic do szlachcianki, poł. XIX w.) ŁozDw 264;

Wybacz mi, wybacz, jedyna moja, widzę, że cię dręczę boleśnie, ale muszę pytać (przyjaciółka do przyjaciółki, poł. XIX w.) ŻmPow2, 155;

Przebaczcie mi, żem was przyszedł nudzić pod pozorem choroby (lekarz do znajomego, poł. XIX w.) KraszDz 107;

Wybacz pani - ale czy historya o jej siostrze należy do rzeczy? (dziennikarz do gadatliwej interesantki, poł. XIX w.) KuczGodz 44;

Wybacz mi pani, że się rozwodzę nad tym przedmiotem (szlachcic do szlachcianki, poł. XIX w.) DmNa 93;

Winienem, przebacz (malarz do ukochanej, lata 60. XIX w.) KraszSt 156.

Choć syntetyczna forma rozkaźnika nie ma dużej wartości honoryfikatywnej, to badane teksty dowodza, że za pomocą takich formuł przepraszano także osoby o wyższej randze pragmatycznej od nadawcy wypowiedzi. W ten prosty sposób miał się zwrócić Jan Kiliński do Stanisława Augusta Poniatowskiego, podkreślając jednocześnie swój brak znajomości form towarzyskich:

Wybaczże mi N. Królu tę furię... gdyż ja na dworskiej retoryce się nie znam MajerKron 82.

Postać formuł kierowanych do wyższych rangą zasadniczo nie różni się od tych stosowanych w relacjach symetrycznych. Ewentualnym wykładnikiem wyższości odbiorcy mogą być adresatywy:

Wybacz mnie, panie miły (mieszczka do komendanta, poł. XVIII w.) ProcPil 168;

Wybacz, marszałku, lecz nie przypuszczam czegoś podobnego (oficer napoleoński, kon. XVIII w.) BielBon1, 151;

Wybacz pan, żem gość niespodziany ale mi noclegu nie odmów (ułan do szlachcica, I poł. XIX w.) GirtOp2, 293;

Przebacz, ojcze i wzajemną pobłogosław naszę miłość (szlachcic, I poł. XIX w.) FrDz2, 115;

Wybacz pani, żem się przed nią chciał schronić, bo mi pan mój największą ostrożność zalecił (masztalerz do arystokratki, I poł. XIX w.) SkarbTar 23;

Przebacz mi, stryju (siostrzeniec do stryja, I poł. XIX w.) FrDz1, 396;

Przebacz mi Heleno, że ja chociaż młodsza z moim zdaniem się odzywam (szlachcianka do znajomej, lata 40. XIX w.) PrusMor 99;

Przebacz pani (mieszczanin do hrabiny, poł. XIX w.) KraszDz1, 211; 
Przebacz mi, jasny panie, za surowo was sądziłem (kozak do hrabiego, poł. XIX w.) ŁozDw 423.

Najrzadziej formuły te występują w roli przeprosin w sytuacji, gdy osoba o wyższym statusie zwracała się do niższej od siebie:

Przebacz, proszę (starościc do plenipotenta, II poł. XVIII w.) WybDr 224;

Wybacz mi waszmość pan, że mu w tym służyć nie mogę (starszy szlachcic do młodego, II poł. XVIII w.) BohK1, 422;

Przebacz, bracie (baron do szewca, I poł. XIX w.) DzierzS 178;

Przebacz pani, że wątpić w tym względzie pozwolę sobie (baron do żony malarza, I poł. XIX w.) FrDz2, 229;

Przebaczcie mój stary, że was trudzę (mieszczanin do chłopa, poł. XIX w.) KraszDz 184.

Frazy z analityczną formą rozkaźnika są zupełnie wyjątkowe:

Niech Pan przebaczy, [...] ale ja pewny byłem, że tu dziś nikogo nie ma (górnik do hrabiego, lata 30. XIX w.) RaRa 206;

Niech mi ciotka dobrodzika przebaczy małe wzruszenie (szlachcic do ciotki, poł. XIX w.) BujSt 139.

Druga najczęściej spotykana postać członu werbalnego, to omawiane czasowniki w trybie orzekającym:

Wybaczysz mi waćpan moją rzetelność (panienka do szlachcica, II poł. XVIII w.) CzarKom 100;

Pani przebaczy nam łaskawie, że się ośmielamy ją nawiedzać (szlachcic do znajomej, pocz. XIX w.) WójN 95;

Wybaczysz mi także, że drugiej twojej sympatyi także nie dzielę (mąż do żony, I poł. XIX w.) KorzDz 49;

Wybacza Jmościulki, ale to mój z bratem kończy chatę (chłopka do szlachcianek, I poł. XIX w.) HoffOpis 247;

Kasztelanowa wybaczy, że ją pożegnam, ale słowo honoru, że muszę się spieszyć (szlachcic, lata 20. XIX w.) SkrabSt 69;

Wybaczysz waść, że tej rady nie przyjmę (starosta do porucznika, lata 20. XIX w.) SkarbSt 95;

Tym razem wybaczysz Regencie, że mu odznaczę trzy marki (starościc do Regenta podczas gry w wista, lata 40. XIX w.) RusWar2, 123;

Przebaczysz pani że lubo mało jej znamy, ośmielam się prosić o naznaczenie godziny, w której bym mógł ją samą zastać (młodzieniec do kupcowej, lata 40. XIX w.) RusWar2, 130;

Wybaczysz pan [...], że sobie tego nie przypominam (marszałek do podczaszyca, poł. XIX w.) BujSt 108;

Wybaczy mi pan, że go na małą chwilkę zostawię samego (dziennikarz do interesanta, poł. XIX w.) KuczGodz 33;

Ksiądz kanonik mi przebaczy, że mu się naprzykrzam (mieszczanin do księdza, poł. XIX w.) KraszDz 154. 
Tak samo jak w przypadku przeprosin z trybem rozkazującym dominują użycia w relacjach symetrycznych. Na dystans między nadawcą a odbiorcą może wskazywać 3. osoba czasownika, ale możliwe było również łączenie formy 2 . osoby z tytulatura pan, pani. Niemal zawsze formuła ma postać zdania złożonego ze zdaniem podrzędnym dopełnieniowym, które określa przewinienie.

W ekscerpowanych tekstach zdarzają się także akty, które mają postać pytania:

Czy wybaczy pani, że stanąłem tak nierychło przy nożętach jej? (kawaler do panny, II poł. XIX w.) CzarKom 104;

A mnie, przebaczyszże rolę twojej rywalki? (szlachcianka do znajomej, lata 40. XIX w.) OsP2, 184.

Sposobem na zwiększenie grzeczności takich przeprosin było obudowanie ich za pomocą formalnych wykładników prośby w postaci czasownika performatywnego. Występują tu dwa schematy: proszę + bezokolicznik lub proszę o + biernik rzeczownika odsłownego:

Proszę wybaczyć mojej otwartości (pułkownik do generała, kon. XVIII w.) BielBon1, 325;

Jeżelim się stał występnym z pokorą o przebaczenie waćpana dobrodzieja prosze (szlachcic do znajomego, kon. XVIII w.) CzarKom 403;

Proszę mi przebaczyć (szlachcic do znajomej, kon. XVIII w.) BolBez1, 33;

Proszę nam jednak wybaczyć, że przybywamy jednak w chwili, gdy pan pragnąłeś użyć przyjemności w swym towarzystwie (kasztelanowa do profesora, I poł. XIX w.) GirtOp1, 220;

Wobec was wszystkich, panowie i bracia, prosze go dziś uroczyście, publicznie o przebaczenie (generał do kapitana, który wyzwał go na pojedynek, I poł. XIX w.) ŁozHis 157;

Proszę mi przebaczyć nieostrożne słowo (prezes do szlachcianki, poł. XIX w.) KraszDwa 375.

Innym sposobem na zwiększenie mocy illokucyjnej przeprosin było tworzenie honoryfikatywnych fraz z czasownikiem raczyć:

Raczysz waćpan dobrodziej przebaczyć mi, że go odważam się zapytać (cudzoziemiec do szlachcica, II poł. XVIII w.) WybDr 394;

Bądź książę litościwy i racz przebaczyć (młynarka do księcia, II poł. XVIII w.) WirMal 154;

Niegodne te wierszyki aplauzów wybaczyć raczq te damy rzecz niedoskonała zrobioną naprędce, w poufałej kompanii (szlachcic do pań słuchających jego wierszy, II poł. XVIII w.) KK 158;

Raczcie wybaczyć, panie moje, jeżelim śmiem was w tej karczmie przyjmować, lecz chciałem urozmaicić zabawę (szlachcic do dam, lata 20. XIX w.) SkarbSt 35;

Racz pani przebaczyć, uniosłem się w jej przytomności, wyznaję moję winę (szlachcic do starszej szlachcianki, I poł. XIX w.) FrDz1, 586. 


\subsubsection{W listach}

W epistolografii badanego okresu zdecydowanie przeważają formuły zawierające tryb rozkazujący. Zwracano się w ten sposób przede wszystkim do równych i wyższych od siebie rangą:

Matko kochana, wybacz, jeśli twoim radom nie mogę być posłusznym (szlachta, II poł. XVIII w.) WirMal 33;

Wybacz, żem jeszcze swą ręką nie pisał, bo czasu nie mam (Karol Radziwiłł do guwernera, 1774) KorRadz 106;

Wybacz W.Pan, że zbyt długie do Niego pisuję listy (Hugo Kołłątaj do barona, 1792) KołLis1, 45;

Wybacz, proszę, że od tak dawna nie pisałem do ciebie (Ignacy Domeyko do przyjaciela, I poł. XIX w.) DomL 7;

Przebacz mi, mój drogi, że cię zawsze utrudzam tymi chilijczykami, którzy w nas nieograniczoną ufność mają (Ignacy Domeyko do przyjaciela, I poł. XIX w.) DomL 96;

Przebacz JW Pan Dobrodziej śmiałości mojej (Euzebiusz Słowacki do Jana Śniadeckiego, 1810) LisRS 17;

Wybacz mi mój Janie, że cię zatrudniam moimi pismami (szlachcic do przyjaciela, 1822) KorFil 316;

Wybacz, że ci nie mogę dużo pisać (mieszczanin do brata, 1831) PamL 44;

Przebacz za nieład w tym liście, ale piszę jak pijany (Fryderyk Chopin do przyjaciela, 1831) ChopKor1, 168;

Przebacz, że dziś dopiero odpisuję (Seweryn Goszczyński do przyjaciela, 1838) GoszLis 29;

Wybacz, mój drogi Eraziu, że się tak samolubnie moim krzyżem z tobą dzielę (Narcyza Żmichowska do brata, 1838) ŻmLis1, 85;

Przebacz mi te brednie (Stanisław Trentowski do wydawcy, 1842) TrenLis 88;

Przebacz teraz mojemu niespodziewanemu natręctwu i wierzaj, że zawsze po staremu wielbię cię i kocham (Bohdan Zaleski do Fryderyka Chopina, 1844) ChopKor2, 119;

Przebacz raz jeszcze, żem się ośmieliła pisać do ciebie (arystokratka w liście do znajomego, lata 40. XIX w.) RusWar4, 158;

Wybacz jakeś łaskawa, Szanowna Pani, moim tak długim zwłokom w odpowiedziach (Adam Mickiewicz do przyjaciółki, poł. XIX w.) MicKon 37;

Wybacz, droga pani (Władysław Syrokomla do Pauliny Wilkońskiej, poł. XIX w.) WilkWsp 277;

Przebacz zatem pani dobrodziko, żem użył takich środków (szlachcic do przyszłej teściowej, poł. XIX w.) DmNa 325;

Wcale niepotrzebnie w dzień twoich imienin z taką prozą wystąpiłam, ale mi to przebacz ze względu na poetyczniejszy początek (Narcyza Żmichowska do przyjaciółki, 1860) ŻmLis2, 170. 
Podobnie jak w przypadku formuł ustnych, również w listach znajdziemy przykłady przeprosin bardziej ceremonialnych, głównie kierowanych do osób o wyższym statusie społecznym od piszącego:

Pokornie proszę wybaczyć (Adam Naruszewicz do Stanisława Augusta Poniatowskiego, 1776) NarLis 479;

Przebaczyć WMPan raczysz zatrudnieniom moim, żem się nieco w odpowiedzi spóźnił (Ignacy Krasicki do generała, 1777) KKor1, 288;

Po milion razy błagam o przebaczenie (sekretarz do Ignacego Potockiego, 1793) TKor 154;

Proszę wybaczyć zbytecznemu deklarowaniu, pierwszy raz w życiu przyjąłem ton kaznodziei (Tomasz Zan do Marii Puttkamerowej, 1822) KorFil 272;

Mocno żałuję i o przebaczenie za to proszę (dostojnik kościelny do dyrektora komisji rządowej do spraw wyznań, przepraszając za udział w powstaniu listopadowym, 1832) SkarbPam 231;

Racz przebaczyć Wasza Książęca Mość śmiałości mojej, iż ważę się z tym listem przesłać załączone dzieło (Stanisław Trentowski do księcia Radziwiłła, 1842) TrenLis 83.

Tyle razy proszę o wybaczenie, że śmiem być powtórnie natrętną (Helena Modrzejewska do dyrektora teatru, 1862) KorMod 45.

Formuły z członem werbalnym w postaci trybu oznajmującego prawdopodobnie były aktami typowo ustnymi. W ekscerpowanej epistolografii poświadczone są jedynie w listach Adama Mickiewicza do Konstancji Łubieńskiej:

Wybaczysz mi Pani takim długi wyjątek (1826) MicKon14;

Wybaczysz nam, że ci daliśmy ten kłopot (poł. XIX w.) MicKon 32.

\section{8. „NIE GNIEWAJ SIĘ”}

\subsubsection{W rozmowach}

Fraza ta w roli przeprosin pojawia się dopiero w okresie nowopolskim. Z badanych tekstów wynika, że była chętnie stosowana szczególnie wśród niższych warstw społecznych oraz w sytuacji, gdy zwracano się do służby czy osób o niższej randze od nadawcy wypowiedzi:

Nie gniewaj się waszmość pan (służąca do stajennego, II poł. XVIII w.) BohK2, 109;

Ale się nie gniewaj waszmość pan (ojciec do guwernera, II poł. XVIII w.) BohK1, 138;

Nie gniewaj się, Petrusiu (szlachcic do służącej, kon. XVIII w.) CzarKom 363;

Nie gniewajcie się (chłop do chłopki, II poł. XVIII w.) BohK2, 280; (chłop do garncarza, poł. XIX w.) KraszJer 102; 
No, no, popie, nie gniewaj się (arystokrata do zakonnika, pocz. XIX w.) ChodźPam 218;

Nie gniewaj się na mnie i żyjmy w przyjaźni (szlachcic do Żyda, lata 40. XIX w.) OsP2, 12;

Nie gniewaj się, moja Anusiu, ostatni to może wieczór, który tu daję (szlachcic do służącej, lata 40. XIX w.) KorzDram 281;

Urszulo!...nie gniewajta sie (rybak do karczmarki, lata 40. XIX w.) RusWar4, 129;

Nie gniewajcie się, mam interes do pana Jeremiasza (kramarz do służącej, poł. XIX w.) ŁozNoc 138;

No, no, nie gniewaj się na mnie, pani Małgosiu, przyrzekam poprawę (mieszczanin po nocnej pijatyce do służącej, poł. XIX w.) ŻmPow1, 261;

Nie gniewajcie się, mój ojcze (mieszczanin do chłopa, poł. XIX w.) KraszDz 184;

Zlitujcie się, nie gniewajcie się na mnie (ubodzy mieszczanie, lata 60. XIX w.) KraszSt 6.

Jeśli pojawia się w kontaktach osób ze stanu szlacheckiego, to uczestnicy interakcji są spokrewnieni:

Nie gniewaj się mój ojcze (córka, II poł. XVIII w.) WybDr 115;

Ależ nie gniewaj się kochany stryju, bo obaczysz, że się unosisz na próżno (bratanek, I poł. XIX w.) KorzKom 140;

Nie gniewaj się moja duszo (żona do męża, lata 60. XIX w.) CieszP 52;

Nie gniewaj się, proszę, a wierz mi trochę (córka do ojca, lata 60. XIX w.) KraszSt 87.

Formuła ta odznaczała się stabilnością. Zakres jej użycia wskazuje, że nie miała dużej wartości honoryfikatywnej. Zwiększano jej uprzejmość głównie za pomocą adresatywów i epitetów pozytywnie wartościujących odbiorcę.

Przypadki stosowania takich przeprosin w sytuacji, gdy osoba o niższej randze pragmatycznej zwracała się do wyżej postawionej są wyjątkowe i formuła ulega wtedy przekształceniu do grzeczniejszej postaci:

Niech się Pan nie gniewa (górnik do hrabiego, lata 30. XIX w.) RaRa 207;

Vox populi, vox Dei, mociumdzieju, proszę się nie gniewać (podczaszyc do marszałka, poł. XIX w.) BujSt 110.

\subsubsection{W listach}

Ten pozornie typowo ustny akt etykiety pojawia się także w kilku listach badanego okresu. Adresatami takich bezceremonialnych przeprosin byli przyjaciele i rodzina:

Hersylko, Teofilu, wy nie gniewajcie się na mnie, jeżeli do was osobno nie piszę (Juliusz Słowacki do rodziny, 1832) KorSł 70; 
Nie gniewaj się, mój luby, mój najdroższy bracie (Narcyza Żmichowska do brata, 1838) ŻmLis1, 67;

Nie gniewaj się, żem nie odpisywał ci, iże nie pisuję (Zygmunt Krasiński do przyjaciela, 1845) KraSł 115;

Nie gniewaj się, kiedy czasem bąknę (Teofil Lenartowicz do przyjaciela, 1852) LisLen 45.

\section{9. „PRZEPUŚĆ/ODPUŚĆ”}

Takie przeprosiny znane od okresu staropolskiego i rozpowszechnione w dobie średniopolskiej ${ }^{15} \mathrm{w}$ badanym okresie wyraźnie zanikają. Akty tego rodzaju są bardzo słabo poświadczone $\mathrm{w}$ badanych tekstach i pochodzą niemal wyłącznie z wieku XVIII:

Prawda... zgrzeszyłem... odpuść panie... posądziłem... (pijany gość na imieninach marszałka, II poł. XVIII w.) KK 98;

Panie kolego, odpuść mnie to, com ci żartem powiedział (książę do kasztelana, kon. XVIII w.) RzewPam 45;

Dobra panno Heleno odpuść mi moją winę (szlachcic do ukochanej, kon. XVIII w.) BolBez1, 32;

Przepuścisz mi JWWMP Dobrodziej tak długą dygresją (Ignacy Krasicki do Franciszka Salezego Potockiego, 1760) KKor 29;

Przepuść mój łaskawco (Stanisław Trembecki do pułkownika, 1802) TremNie 238.

\subsection{UWAGI KOŃCOWE}

Początek doby nowopolskiej przyniósł duże zmiany w formułach etykietalnych służących przepraszaniu. W porównaniu z wcześniejszym okresem zwiększa się repertuar tych aktów, co być może jest związane również ze zdecydowanie częstszym niż dawniej ich używaniem. Najstarsze formuly werbalne z czasownikami przepuścić i odpuścić wyraźnie zanikają. Rozpowszechnia się dotąd rzadko stosowany performatyw przepraszam i szybko staje się najchętniej stosowaną formułą. Pojawiają się także zupełnie nowe typy pośrednich aktów przeprosin: bardzo popularne są formuły z członem werbalnym zawierającym darować. Nowością jest także fraza nie gniewaj się. Nadal chętnie używano aktów, w których jądrem są czasowniki wybaczyć i przebaczyć.

${ }^{15}$ M. Cybulski, Obyczaje językowe..., s. 152. 
Postać formalna przeprosin jest mocno zróżnicowana, ale w przypadku aktów pośrednich zdecydowanie przeważają formuły zawierające tryb rozkazujący. Co ciekawe, użycie takich fraz o niewielkiej wartości honoryfikatywnej było powszechne nie tylko w relacjach równorzędnych, ale także wówczas, gdy osoba o niższej randze pragmatycznej zwracała się do wyżej postawionej. Dominują formuły proste o raczej ubogiej etykietalnej obudowie. W większości przypadków akty ustne znajdujemy także w komunikacji listownej. 


\section{ZAPROSZENIA}

Zaproszenia to również odmiana prośby - nadawca prosi odbiorcę, by ten z nim przebywał i zakłada, że jest to zgodne z wolą adresata ${ }^{1}$. Akty zaproszeń z czasem wykształciły własny czasownik performatywny zapraszam, który wyróżnia je spośród innych próśb i dlatego zasadne wydaje się być ich osobne omówienie.

Akty te możemy podzielić na dwa podstawowe typy²: prośby (ustne lub pisemne) o przybycie na jakąs uroczystość czy na spotkanie towarzyskie w niedalekiej przyszłości oraz zaproszenia dotyczące danej chwili - mógł je kierować gospodarz do gościa, ale mogła to być również propozycja wspólnego spędzenia czasu np. w gospodzie czy w teatrze. W przypadku drugiego typu zaproszeń należy dodatkowo wyodrębnić akty częstowania ${ }^{3}$, które jednak w badanym okresie nie wykształciły żadnych osobnych formuł i dlatego omawiane są w tym rozdziale.

\subsection{FORMUŁY ORALNE}

\subsection{1. „zapraszam na”}

Czasownik illokucyjny właściwy dla tego aktu mowy w okresie średniopolskim występował jedynie w zaproszeniach pisemnych ${ }^{4}$. W początkach doby nowopolskiej zaczyna pojawiać się także w formułach konwersacyjnych, ale jest jeszcze bardzo rzadki. Poświadczone użycia ograniczają się do środowiska szlacheckiego:

Waszmość pana tedy na ten akt weselny zapraszamy (ojciec panny młodej do znajomego szlachcica, II poł. XVIII w.) BohK1, 422;

$\mathrm{Na}$ obiady zapraszam do siebie (starosta do kwestarza, II poł. XVIII w.) ChodźPam 141;

I $n a$ to spectaculum wszystkich panów braci szlachtę i dobrodziejów zapraszam (szlachcic na sejmiku, II poł. XVIII w.) ChodźPam 30;

Zapraszam panów braci na pławienie (szlachcic na sejmiku, II poł. XVIII w.) ChodźPam 31;

Zapraszam cię na komedyą (hrabia do grafa, lata 20. XIX w.) OlPam1, 170.

${ }^{1}$ M. Marcjanik, Polska grzeczność językowa, Kielce 2000, s. 101.

2 M. Cybulski, Obyczaje językowe dawnych Polaków. Formuty werbalne w dobie średniopolskiej, Łódź 2003, s. 141.

${ }^{3}$ M. Marcjanik, Polska grzeczność..., s. 81-100.

${ }^{4}$ M. Cybulski, Obyczaje językowe..., s. 142. 


\subsection{2. "prosimy"}

W omawianych aktach w członie werbalnym zdecydowanie najczęściej występowało proszę. Niekiedy sam czasownik performatywny tworzył zaproszenie. Jednak użycie takich fraz ograniczało się do sytuacji, gdy nie było wątpliwości, czego owo prosimy dotyczy - zwykle gość właśnie wchodził w progi domu i była to zaplanowana wcześniej wizyta. Gospodarz używał liczby mnogiej, bo wypowiadał zaproszenie w imieniu wszystkich domowników. Formule werbalnej najczęściej towarzyszyły biernikowe formy adresatywne:

Prosiemy waszmości (chłop do organisty, kon. XVIII w.) BoCu 119;

Księdza dobrodzieja prosimy z sercem otwartym (pułkownik do kwestarza, pocz. XIX w.) WójN 131.

Krótkość takiego zaproszenia powodowała, że dla wzmocnienia efektu grzecznościowego czasami je reduplikowano:

A prosimy, bardzo prosimy (szlachcic do adoratora córki, lata 40. XIX w.) OsP1, 94;

Prosiemy pana barona, prosiemy (mieszczanin do barona, poł. XIX w.) KraszDz 45.

\subsection{3. „proszę" + bezokolicznik}

Inne bardzo proste formuły zaproszeń składały się z proszę i bezokolicznika, a jedynym elementem obudowy etykietalnej mogły być biernikowe adresatywy:

Prosiemy waszmość dobrodzieja usieść (szlachcianka do gościa, II poł. XIX w.) BohK2, 380;

Jeszcze prosze przez cztery dni zabawić z nami (hetmanowa do adiutanta, kon. XVIII w.) PamGąs 77;

Prosze zaszczycić mój dom swoją bytnością (starościna do oficera, pocz. XIX w.) WójN 24;

Proszę się rozgościć i bydź bez ceremonii (szlachcic do gości, lata 20. XIX w.) PawEd 57;

Proszę usiáść (modystka do znajomego, lata 40. XIX w.) RusWar2, 151;

Prosiemy siadać (szlachcianka do gościa, poł. XIX w.) DzierzD1, 97;

Prosiemy nas odwiedzać (szlachta, poł. XIX w.) DzierzD1, 100;

Prosze pokosztować (Żyd do szlachcica, poł. XIX w.) KraszJer 134;

Prosze pana barona zajść do pokoju, bardzo proszę (Żydówka, poł. XIX w.) KraszDz 470. 


\subsection{4. "proszę na"}

W schemacie tym po czasowniku następuje wyrażenie przyimkowe, które określa cel (rzadko miejsce) spotkania - najczęściej posiłek. Konstrukcja proszę $n a$ była używana przez wszystkie warstwy społeczne: szlachtę, mieszczan oraz chłopów:

Proszę teraz na moję tabaczkę (szlachcianka do kwestarza, II poł. XVIII w.) ChodźPam 132;

Całe koło prześwietnych urzędników na obiadek pokornie proszę (wojewoda do szlachty na sejmiku, II poł. XVIII w.) ChodźPam 36;

Prosze pana Łowczego i obecnych tu przyjaciół moich na jutro do mnie na obiadek szlachecki (stolnik do szlachty, kon. XVIII w.) PamGąs 16;

Prosiemy na śniadanie (młynarz do chłopów, kon. XVIII w.) BoCu 154;

Prosze pana starosty z sobą na pokoje (książę Karol Radziwiłł do starosty, II poł. XVIII w.) RzewLis1, 136;

Panie Kochanku, proszę na teatr, pojdź waść ze mną (książę Karol Radziwiłł do znajomego szlachcica, II poł. XVIII w.) PamOch1, 283;

Proszę waćpana jutro $n a$ obiadek (książę Karol Radziwiłł do znajomego szlachcica, II poł. XVIII w.) PamOch1, 25;

Ja panie proszę na wieczerzę (szef szwadronu szwoleżerów gwardii do kasztelanowej i jej córki, pocz. XIX w.) BielBon2, 64;

Proszę cię na skromną wieczerzę (szlachcic do gościa, I poł. XIX w.) OrWęd 119;

Prosi ojciec, prosi matka i ja was proszę na dziewiczy wieczór i na chleb, i na sól (chłopka do szlachcianki, I poł. XIX w.) BłP 256;

Prosze pana na tabakę (chłop do ekonoma w karczmie, lata 40. XIX w.) KraszU 83.

Możliwe, choć rzadko spotykane, było zastapienie czasownika performatywnego konstrukcją analityczną, która czyniła akt mniej bezpośrednim:

Przyszedtem prosić Wielebność Waszę na jutrzejszy fest do nas z całym konwentem, a po służbie Bożej na uczciwą pieczeń baranią i na konsolacyą, ot co jest (ksiądz kustosz do przeora, II poł. XVIII w.) ChodźPam 63;

Gdybym miał być natrętnym i mógt prosić pana dobrodzieja jako ziomek na kieliszek szampana (baron do znajomego, poł. XIX w.) KraszDz 128;

Możemy pana dobrodzieja prosić na herbatkę do mojej żony? (rządca do lekarza, poł. XIX w.) KraszJary 72 - zaproszenie w formie pytania jest grzeczniejsze ${ }^{5}$.

${ }^{5}$ Zgodnie z zaproponowaną przez R. Lakoffa regułą grzecznościową: „daj możliwość wyboru”. R. Lakoff, The Logic of Politeness! or, Minding Your P's and q's, [w:] Papers from the Ninth Regional Meeting Chicago Linguistic Society, Chicago 1973. 
Prezentowane powyżej formuły były stosowane zarówno w sytuacji, gdy uczestnicy interakcji mieli podobny status społeczny jak i w relacji asymetrycznej. Niezależnie jednak od rangi zapraszającego i zapraszanego ich obudowa etykietalna jest uboga i zwykle ogranicza się do form adresatywnych, a czasami nawet $\mathrm{z}$ nich rezygnowano.

\subsection{5. "proszę do"}

Szablon ten był używany przede wszystkim przez gospodarzy zapraszających gości. Po czasowniku illokucyjnym i ewentualnych adresatywach występuje dopełnienie przyimkowe wskazujące miejsce gościny:

Proszę pomaleńku, panów dobrodziejów do pokoju (wojski do szlachty, II poł. XVIII w.) ChodźPam 49;

Prosze, prosze do siebie (miecznikowa do oficera zapraszając go do swojej karety, II poł. XVIII w.) KoźPam1, 265;

A to ja proszę do mojej karety (wydawca do Kajetana Koźmiana, lata 20. XIX w.) KoźPam2, 211;

Prosze pana do mojej stancji (pisarz komory celnej do szlachcica, II poł. XVIII w.) KoźPam1, 295;

Proszę do mego pokoju (szlachcic do znajomego, kon. XVIII w.) CzarKom 392;

Moi panowie, jeżeliście łaskawi, proszę asanów jutro do siebie (hrabia do szlachty, I poł. XIX w.) KorzDram 237;

Proszę pana do pokoju (chorażyna do hrabiego, I poł. XIX w.) OlPam1, 200;

Prosze panów do siebie (szlachta, poł. XIX w.) RusWar4, 150;

Prosze panów do pokojów (szlachcianka do gości, poł. XIX w.) KraszDwa 197;

Proszę do Sali, a ja zaraz i z obiadkiem, i z kawą nadejdę (szlachcianka do gości, poł. XIX w.) KraszDwa 198;

Proszę panów do Sali balowej (szlachcic do kolegów, poł. XIX w.) DmNa 162;

Jeśli pan nie pogardzi kawalerską herbata, to proszę do siebie (nauczyciel do znajomego, poł. XIX w.) CieszT2, 21;

Prosze do izby (plenipotent do pisarza, poł. XIX w.) KraszH 80.

Również te akty zaproszeń charakteryzuje prostota. Jedynie raz w badanych tekstach znajdujemy przykład bardziej rozbudowanej formuły stworzonej według omawianego schematu:

Jeżeli pan dobrodziej nie pogardzi ubogą chata, to prositbym do siebie (zubożały szlachcic do podróżnego, II poł. XVIII w.) WójDw 35. Performatyw zastapiono tu trybem przypuszczającym, który wyraża wyższy stopień grzeczności. Dodatkowo zaproszenie zostało obudowane zdaniem warunkowym, w którym gospodarz, zgodnie z konwencją, podkreśla skromne warunki w jakich może ugościć przybysza. 


\subsection{6. „proszę" + zdanie okolicznikowe celu}

To bardziej rozbudowane, a przez to grzeczniejsze zaproszenie w badanym materiale występuje rzadko i wyłącznie w środowisku szlacheckim. W zdaniu podrzędnym mógł pojawić się honoryfikatywny czasownik raczyć, który dodatkowo podkreślał ceremonialność takiego aktu:

Prosiemy więc księdza kanonika, abyś nam nie odmówił na ten dzień jeden zabawienia się w domu naszym (stolnik do kanonika, kon. XVIII w.) PamGąs 234;

Proszę, żebyś się raczył pofatygować jutro do nas na objadek (baron do regenta, lata 40. XIX w.) RusWar3, 123;

Prosimy bardzo xiędza Hieronima, abyś w domu naszym wypoczął (szlachcic do bernardyna, poł. XIX w.) DmNa 332.

$\mathrm{W}$ jednym z zaproszeń czasownik illokucyjny został zastapiony formą analityczną:

Przychodzę sam prosić Waćpana, byś raczył wstapić w progi nasze i był nam gościem łaskawym (szlachcic do oficera, II poł. XVIII w.) ŁozG 42.

\subsubsection{Formy imperatywne}

Najprostsze zaproszenia miały postać rozkaźnika. Imperatywne formy syntetyczne były używane przede wszystkim w relacjach symetrycznych oraz gdy zapraszający miał wyższą rangę pragmatyczną, choć $\mathrm{w}$ jednym $\mathrm{z}$ badanych tekstów zwraca się w ten sposób również chłop do szlachcica:

Chodźcie do czeladnej izby zjeść co Pan Bóg dał (I poł. XIX w.) OrWęd 196.

Jak widać $\mathrm{w}$ analizowanym materiale, taki niewyszukany sposób zapraszania rozpowszechniony był we wszystkich warstwach społecznych, a niemal jedynym elementem obudowy etykietalnej mogły być rzadko pojawiające się adresatywy:

Chciej waszmość pan usieść (szlachcianka do gościa, II poł. XVIII w.) BohK2, 331;

Odwiedźcie mnie jutro przynajmniej na godzin dwie przed pokojami (hetmanowa do znajomych, kon. XVIII w.) PamGąs 48;

Koledzy! zjedzcie ze mną obiad (Tadeusz Kościuszko do adiutantów, kon. XVIII w.) PamGąs 89;

Odwiedź mnie jeszcze (Stanisław Staszic do Kajetana Koźmiana, lata 20. XIX w.) KoźPam2, 208;

Panie podstarości [...] chodź wasan wypić z nami kieliszek wina (szlachcic do podstarościca, lata 30. XIX w.) OrWęd 83;

Bqqdź u mnie jak we własnym domu (szlachcic do gościa, lata 30. XIX w.) OrWęd 141; 
Teraz rozgość się kochanie (mieszczka do krewnej, lata 40. XIX w.) RusWar2, 182;

Siadajcie, siadajcie nie marudźcie (chłopi, poł. XIX w.) KraszJer 126.

Analityczne formy rozkaźnika w badanych tekstach nie są liczne. Dłuższa postać formuły wyrażała wyższy stopień grzeczności i dlatego zwykle była używana przez osoby o niższej randze od zapraszanego:

Niech pan z łaski swojej się rozgości i zdejmie ten oręż (generał do starosty, II poł. XVIII w.) RzewLis1, 225;

Niech Jmościuszki wejdq przez łaskę swoją i zobaczq, jakie będzie walne domostwo (chłopka do szlachcianek, I poł. XIX w.) HoffOpis 248;

Niech wielmożny pan siada (karczmarz do szlachcica, poł. XIX w.) ŁozDw 307.

Obudowa grzecznościowa jest tu bogatsza: pojawiają honoryfikatywne zwroty z taski swojej, przez łaskę swoja.

Imperatiwus presuponuje, że nadawca jest w pozycji nadrzędnej wobec odbiorcy i ma prawo wydawać mu polecenia ${ }^{6}$. Z tego powodu zaproszenia, w których człon werbalny ma postać rozkaźnika, bardzo często posiadają dodatkowo formalny wykładnik prośby w postaci czasownika performatywnego proszę dzięki temu formuła staje się uprzejmiejsza. Pozycja czasownika illokucyjnego jest swobodna: może zarówno poprzedzać formę imperatywną, następować po niej jak i zajmować miejsce między dwoma rozkaźnikami:

Toż się u mnie zostań z całego serca proszę (książę do szlachcica, II poł. XVIII w.) KarpP 95;

Zasiadźcież raz, proszę was bardzo (szlachcianka do przyjaciółek, II poł. XVIII w.) CzarKom 344;

Siadajże waszmość pan, proszę (szlachcianka do znajomego, II poł. XVIII w.) CzarKom 331;

A więc proszę, siadaj pan ze mną (generałowa do szlachcica, II poł. XVIII w.) PamOch2, 7;

Proszę, panie bracie, rozgośćcie się w moim domu (starosta do sługi księcia, kon. XVIII w.) RzewPam 341;

Oto jest miejsce, siadaj proszę ze mną (hetmanowa do adiutanta, kon. XVIII w.) PamGąs 1793;

Siadaj więc z nami, prosimy cię z zastrzeżeniem: czym chata bogata, tym rada (pułkownik do aplikanta sądowego, lata 30. XIX w.) JanAu 511;

Prosze was, wejdźcie (łowczy do gości, I poł. XIX w.) KorzDram 7;

Jeżeli ci u nas nie jest źle kochany poruczniku, to ot zostań już i nadal, prosimy serdecznie, co Bóg da, zjesz z nami (major do porucznika, I poł. XIX w.) PamUł 169;

Siadajże pan, proszę (hrabina do lekarza, poł. XIX w.) KraszJary 88;

${ }^{6}$ R. Grzegorczykowa, Wprowadzenie do semantyki językoznawczej, Warszawa 2001, s. 146. 
No siadaj, prosze, i spocznij (hrabia do przyjaciela, poł. XIX w.) KraszDwa 309.

Zaprezentowane przykłady pokazuja, że proszę towarzyszą niekiedy okoliczniki, które dodatkowo zwiększają grzeczność aktu. Warto też zauważyć, iż w zaproszeniach, które mają formalne wykładniki prośby, pojawia się przy rozkaźniku partykuła wzmacniająca $\dot{z} e$. Nie obserwujemy jej w formułach zawierających jedynie imperatiwy, w których nic nie łagodzi ich wymowy.

$\mathrm{Z}$ ekscerpowanych tekstów wynika, że proszę występuje niemal wyłącznie $\mathrm{w}$ formułach z syntetycznym rozkaźnikiem. Najwyraźniej forma analityczna prezentowała dużo wyższy stopień grzeczności i nie było potrzeby obudowywania jej prośbą. Jedyny przykład zaproszenia łączącego te elementy to:

Proszę, niech się babunia rozgości (wnuczka do babki, I poł. XIX w.) KorzKom 334.

\subsection{8. „racz / pozwól” + infinitiwus i przeksztalcenia}

Tego rodzaju zaproszenia, choć, podobnie jak wcześniej omawiane, zawierają formy trybu rozkazującego, prezentują o wiele wyższy stopień grzeczności $\mathrm{z}$ racji użytego $\mathrm{w}$ nich czasownika nacechowanego honoryfikatywnością. Stosowano je zarówno wtedy, gdy uczestnicy interakcji mieli podobne rangi pragmatyczne, jak i wówczas, gdy zwracano się do osoby o wyższym statusie:

Panie Stefanie, na święta wyjadę do pana chorążego, racz przyjąć gościnę, to i razem ruszymy (szlachta, II poł. XVIII w.) WójDw 76;

Racz pani przyjać mój dom na mieszkanie, póki w tych stronach zabawisz (szlachcic do szlachcianki, I poł. XIX w.) BłP 398;

Każ swoim koniom odejść i pozwól sobie ofiarować miejsce w moim „baloniku" (szlachta, przeł. XVIII/XIX w.) BykPam 110;

Pozwól Jaśnie Pani i nie gardź śniadaniem ubogiej żydówki (karczmarka do szlachcianki, lata 40. XIX w.) PrusMor 96 - w tym wypadku samo pozwól bez infinitiwu pełni funkcję zaproszenia.

Zmodyfikowaną postać formuły spotykamy w inwitacji, którą skierował komendant wojskowy do Stanisława Augusta Poniatowskiego:

Raczysz królu łaskawy przyjąć ten mój namiot na spoczynek dla siebie PamRadz 103.

Imperatiwus został tu zastapiony trybem oznajmującym zapewne ze względu na osobę króla, do której nigdy nie wypadało zwracać się za pomocą rozkaźnika - nawet w przypadku typowo grzecznościowych czasowników.

$\mathrm{W}$ ekscerpowanych tekstach zdarzają się również konstrukcje $\mathrm{z}$ analityczną formą imperatiwu:

Niech pan prezes raczy usiassć (szlachcic, I poł. XIX w.) KorzKol 62;

Niech wielmożny pan pozwoli stużyć sobie tem co Bóg dał (gajowy do szlachcica, II poł. XVIII w.) RzewLis 89. 


\subsubsection{Inne formy}

Oprócz wyżej omówionych formuł w badanym materiale jest wiele zaproszeń, które nie prezentują żadnego ustalonego szablonu. Często funkcję tego aktu etykiety pełnią pytania - szczególnie w przypadku częstowania:

Malwinko, nie chcesz czekolady? (szlachcianka do znajomej, II poł. XVIII w.) WirMal 68;

Mogę służyć herbatą? (baron do szlachcianki, II poł. XVIII w.) FrDz2, 238;

Może pan pozwoli sobie czem służyć? Są pierogi i dobra śmietana (ubogi szlachcic do zamożnego, lata 20. XIX w.) OlPam1, 39;

Może pan pozwoli szklaneczkę miodu? (chorąży do kapitana, lata 20. XIX w.) OlPam1, 215;

Nie napijesz się wódki? (chłop do parobka, poł. XIX w.) KraszJer 137;

Pan marszałek będzie może łaskawy? Herbata za chwilę w altanie. (podkomorzanka, poł. XIX w.) BujSt 289;

Wypijesz pan kieliszek tego wina? (lekarz do mieszczanina, poł. XIX w.) KraszDz 198;

Czymże bym mógł służyć? może kieliszek wina? (sąsiad do sąsiada, poł. XIX w.) KraszH 93.

Również zaproszenie do tańca miało postać pytania:

Pozwoliszże mi pani [...] służyć sobie i do następnego tańca? (szlachta, lata 40. XIX w.) OsP1, 38;

Czy mogę panią prosić do mazura? (szlachta, poł. XIX w.) CieszT2, 73.

Znajdujemy też przykłady całkowicie zindywidualizowanych aktów zaproszeń, w których próżno szukać jakichkolwiek schematów np.:

Mospanie wojski dobrodzieju, jutro piątek, szczupak na szaro czekać będzie na pana na obiadku, suplikuję, nie przyjmując żadnej exkuzy (wojewoda do wojskiego, II poł. XVIII w.) ChodźKon 124;

Spodziewam się, że jak zawsze łaskaw był pan na sługę swego, tak i dziś nie odmówisz prośbie i zaszczycisz swą przytomnością akt weselny, a co więcej pobłogosławisz dziecku memu (ubogi szlachcic do bogatego zapraszając na wesele córki, I poł. XIX w.) KuKas 173;

Pana Ludwika zatrzymuję na obiad (mieszczka do znajomego, poł. XIX w.) ŻmPow1, 246.

\subsection{FORMUŁY EPISTOLARNE}

W ekscerpowanej korespondencji przykłady zaproszeń są nieliczne. Tak samo jak w aktach oralnych, dominują formuły z czasownikiem prosić. Mogły mieć one bardzo prostą postać: 
Na dzisiejszego imiennika Jakubowskiego proszę WPana na obiad z Wyrwiczem (Stanisław August Poniatowski do Adama Naruszewicza, 1774) KorNar 21;

Prosimy do Kurowa (Grzegorz Piramowicz do Ignacego Potockiego, 1781) KorPot 98;

Proszę Cię najmocniej o to, żebyś mógł dzień jaki z powrotem zabawić, albo żebyś przynajmniej na noc przyjechał (Wincenty Pol do przyjaciela, 1839) LisPol 39.

Zdarzały się również zaproszenia bardziej ozdobne. Performatyw został w nich zastapiony formułami werbalnymi, które zawierają czasowniki nacechowane honoryfikatywnie:

Poważam się prosić wielmożnego pana dobrodzieja, ażebyś wraz z całą familią w przyszły czwartek do sługi swego na obiadek zjechać raczył (szlachcic do znajomego, 1826) SkarbSt 30;

Xięstwo Czartoryscy maja zaszczyt prosić do siebie J. W. P. Chopin Fryderyka na wieczory w soboty o godzinie dziewiątej (1846) ChopKor2, 179.

Odbiorcy tych listów są dodatkowo dowartościowywani przez wieloskładnikowe adresatywy.

W badanych tekstach spotykamy też rymowane zaproszenie wysłane przez przyjaciół do Kazimierza Brodzińskiego:

Pan Kazimierz niech prośby wysłucha

I w dniu jutrzejszym dorożką czy pieszo

Na skromny obiad przybędzie na Szucha (I poł. XIX w.) DmochWsp 123.

Trudno na podstawie tak szczupłego materiału w pełni ocenić zależność między rangami nadawcy i adresata a postacią formuły. Wydaje się jednak, że w początkach okresu nowopolskiego panowała w tej dziedzinie spora swoboda. Świadczą o tym również ówczesne podręczniki sztuki epistolarnej. Wyodrębniały one kategorię „listy zapraszające” i podawały wzory zaproszeń na różne okazje: chrzciny, pogrzeb, wesele, urodziny, obiad itp. często z uwzględnieniem rangi zapraszanego i zapraszającego. W zamieszczonych w nich przykładowych listach znajdujemy najróżniejsze, często mocno zindywidualizowane akty. Wśród pisemnych zaproszeń wyróżniano bilety i listy. W listowniku M. Korzeniowskiego czytamy: „Zaproszenie na zaręczyny, wesela, chrzciny, pogrzeb, obiady zwykle odbywają się listownie, jeźli osoby nieznajdują się w miejscu, inaczej zaś przez bilety. Zaczyna się zwyczajnie od powodu do zaproszenia, proszenia, prosząc o udział w zabawie lub czem innem, oraz dodając jaka radość ztąd wyniknie, jeźli osobą jego będziem zaszczyceni ${ }^{7 ”}$.

${ }^{7}$ M. Korzeniowski, Wybór wzorowych listów we wszelkich stosunkach i okolicznościach potocznego życia. Wzory do władz rzqdowych, wekslów, obligów, kontraktów, cessyi, testamentów, rozmaitych zapisów, zaświadczeń, wszelkich aktów urzędowych i.t.p. z dołqczeniem krótkich obiaśnień nad temiż, Wrocław 1847, s. 193. 
Choć w autentycznej korespondencji nie pojawia się czasownik zapraszać, to w listach i biletach poradnikowych jest on używany. W listowniku S. Szymańskiego $^{8}$ z 1784 r. znajdujemy na przykład :

Mam honor zapraszać Wmć Pana na dzień jutrzejszy do mnie na obiad;

Dnia jutrzejszego mam przyjaciół na obiedzie: do tak miłego mi grona Wmć Pana zapraszam;

Dzień dziwnie pogodny, cały dom mój dziś wyrusza na przejażdżkę do... Donoszę o tym Wmć Panu, i oraz do kompanii naszej zapraszam.

Także w poradniku M. Korzeniowskiego ${ }^{9}$ nie brak takich formuł:

Ośmielam się WMCPana Dobr. z całą familją do siebie zaprosić;

Dnia 10 t. m. wyprawiam małą wieczerzę, na którą WMCPana Dobr. oraz Jego godną małżonkę, uniżenie zapraszam.

Inny typ zaproszenia obserwujemy w subskrypcjach. Są to ogólne zachęty do odwiedzin nadawcy bez podania konkretnej daty. Formuły te mają postać prostego rozkaźnika:

Przyjeżḋaj, przyjeżdżaj zdrowy na świeże bożonarodzeniowe kiełbasy (Jan Czeczot do Adama Mickiewicza, 1819) KorFil 46;

Bądź zdrowa i zawsze łaskawa i nie zaniedbaj nas odwiedzić (Adam Mickiewicz do przyjaciółki, I poł. XIX w.) MicKon 38;

Skoro będziesz mogła, przyjedź do nas (Adam Mickiewicz do przyjaciółki, I poł. XIX w.) MicKon 45.

\subsection{UWAGI KOŃCOWE}

Zaproszenia w początkach doby nowopolskiej prezentują dość duże zróżnicowanie formalne. Właściwy dla tego aktu etykiety performatyw zapraszam jest rzadko używany, natomiast dominują formuly zawierające różne postaci czasownika prosić oraz rozkaźniki.

W badanym okresie odpowiedzi na zaproszenia miały bardzo swobodny charakter i trudno znaleźć w nich jakieś znamiona formuliczności. Widoczna jest jednak, znana już w okresie średniopolskim ${ }^{10}$ konwencja, by zaproszenie traktować jak rozkaz. Świadczą o tym takie dialogi:

- Nie łaska do mnie na wista?

- Jeśli każesz. (znajomi, lata 30. XIX w.) KraszPam 108;

- Do naszej loży jesteś zaproszony/Jutro zaś pojedź, do dziesiątej z rana z konną jazdą zaczekam na mojego pana/Potem u nas na obiedzie/Dobrze, kochany Alfredzie?

\footnotetext{
${ }^{8}$ S. Szymański, Wzory biletow, listow..., s. 57-63.

${ }^{9}$ M. Korzeniowski, Wybór wzorowych listów..., s. 200-201.

${ }^{10}$ M. Cybulski, Obyczaje językowe..., s. 149.
} 
- Tak, jutro, Wacławie/Na twoje miłe rozkazy się stawię. (przyjaciele I poł. XIX w.) FrDz1, 143.

Również w listowniku S. Szymańskiego" ${ }^{11}$, który podaje wzory „odpisów” znajdziemy dowody ciagłej żywotności tej konwencji:

w odpowiedzi na zaproszenia na obiad: „Bardzo żałuję, że tak miłego dla mnie rozkazu Wmć Pana dopełnić nie mogę, przymuszonym będąc cały wieczór strawić w domu, dla dotarcia wiadomego interesu.";

w odpowiedzi na zaproszenie na przejażdżkę: „Choćby nie dzień tak piękny, to wola Wmć Pana i rozkaz dosyćby miały mocy nade mną do wyruszenia mnie $\mathrm{z}$ domu”.

${ }^{11}$ S. Szymański, Wzory biletow, listow..., s. 62-63. 


\section{PODZIĘKOWANIA}

Podziękowania należą do wyrażeń grzecznościowych o charakterze reaktywnym: zawsze są odpowiedzią na bodziec - werbalny lub niewerbalny. Według M. Marcjanik akty te możemy podzielić na trzy rodzaje. Pierwszy to podziękowania właściwe, które wyrażają wdzięczność za przysługę. Kolejne to podziękowania kurtuazyjne - konwencjonalne reakcje na grzecznościowe akty mowy typu życzenia, zaproszenia, gratulacje itd. oraz podziękowania wtórne, pełniące w rzeczywistości inne funkcje komunikacyjne np. kończenie kontaktu ${ }^{1}$. Okazywanie wdzięczności należy do podstawowych zasad grzecznościowych i zarówno dziś, jak i w badanym okresie, podziękowania to jedne z najczęściej stosowanych aktów językowej etykiety.

\section{1. „DZIĘKUJĘ”}

W początkach okresu nowopolskiego najczęściej jądrem formuł werbalnych wyrażających wdzięczność był czasownik performatywny. Pierwotnie dziękować odnosiło się tylko do sfery religijnej - oznaczało relację człowieka do Boga. Z czasem wyraz ten uległ desakralizacji i wszedł do polszczyzny ogólnej². Dziękuję było znane i używane we wszystkich warstwach społecznych: zarówno przez arystokrację, jak i przez chłopów.

W ekscerpowanych tekstach sam performatyw pozbawiony jakiejkolwiek obudowy etykietalnej występuje rzadko:

Dziękuję (kapitanowa do szlachcica, pocz. XIX w.) ChodźKon 249; (szlachta, I poł. XIX w.); (mieszczanin do chłopki, poł. XIX w.) KraszDz 189; (sędzia do szlachcica, poł. XIX w.) ŁozDw 327;

Dziękujem (chłopi do Cyganki, II poł. XVIII w.) KniaźDram 149;

Dziękujewa (wieśniacy do szlachcianki, I poł. XIX w.) KorzOk 82.

Zwykle formuła była amplifikowana przede wszystkim przez celownikowe i wołaczowe adresatywy a niekiedy dodatkowo także przez formy atrybutywne:

Dziękujemy tatulu (chłopka do ojca, II poł. XVIII w.) WybDr 251;

Dziękuje dobrodziko (kwestarz do szlachcianki, II poł. XVIII w.) ChodźPam 135;

Dziękuję, mości dobrodzieju (kupiec do szlachcica, II poł. XVIII w.) BohK1, 186;

Dziękuję ci, Nastuleńko (służący do służącej, II poł. XVIII w.) BohK2, 346;

Dziękuję ci, mości oficerze (oficer do kolegi, II poł. XVIII w.) ŁozG 20;

${ }^{1}$ M. Marcjanik, Struktura komunikacyjna podziękowania, „Socjolingwistyka” 1994, t. 14, s. 75.

${ }^{2}$ K. Długosz-Krurczabowa, Stownik etymologiczny języka polskiego, Warszawa 2006, s. 119-120. 
Dziękuje prawy obywatelu (Stanisław August Poniatowski do Jana Kilińskiego, II poł. XVIII w.) MajerKron 81;

Dziękujemy wasmości (chłopi do młynarza, kon. XVIII w.) BoCu 56;

Dziękuje panu (szlachcic do sędziego, lata 80. XVIII w.) KoźPam1, 142; (ubogi szlachcic do bogatego, początek XIX w.) WójSp 129; (szlachcianka do szlachcica, poł. XIX w.) KraszDwa 323;

Dziękuję ci mon frére (szlachcic do brata, II poł. XVIII w.) RzewLis1, 106;

Dziękuję ci, panie hrabio (generał, pocz. XIX w.) PuzPam 62;

Tomicki, dziękuję ci (książę Konstanty do dowódcy ułanów, I poł. XIX w.) PamUł 14;

Dziękuję ci, mój drogi (żona do męża, I poł. XIX w.) MicPam 15;

Dziękujemy, panie arendarzu (góral z siostrzenicą do Żyda, I poł. XIX w.) KorzDram 186;

Dziękuje jaśnie wielmożny panie (Żyd do szlachcica, I poł. XIX w.) KorzKol 23;

Dziękuje ci, dobra matko (szlachcic, I poł. XIX w.) KorzKom 126;

Dziękuję jegomości (szeregowiec do sędziego, I poł. XIX w.) KorzSt 93;

Dziękuje panoczku (Cyganka do rządcy, lata 20. XIX w.) OlPam1, 279;

Dziękuję ci dobra Julio (mieszczka do przyjaciółki, lata 40. XIX w.) KuWar3, 85;

Dziękuje ci (szlachta, poł. XIX w.) CieszT2, 240;

Dziękuje jasny panie (kozak do szlachcica, poł. XIX w.) ŁozDw 274;

Dziękuję ci, Morysiu (szlachcianka do kuzyna, poł. XIX w.) ŻmPow2, 29;

Dziękuję hrabiemu (syn plenipotenta do hrabiego, poł. XIX w.) KraszH 206.

Innymi, chętnie stosowanymi w celu intensyfikacji, elementami obudowy grzecznościowej podziękowań były okoliczniki stopnia i sposobu. Trudno precyzyjnie określić, na ile faktycznie zwiększały one moc illokucyjną aktu, gdyż w badanych tekstach repertuar przysłówków jest raczej ograniczony, co zapewne świadczy o ich konwencjonalizacji. Najczęściej spotykane to bardzo i serdecznie. Szyk czasownika i okolicznika był swobodny:

Dziękuje pokornie (szlachcic do zakonnika, II poł. XVIII w.) ChodźPam 60;

Dziękujemy ci serdecznie (wojewoda do wojskiego, II poł. XVIII w.) ChodźKon 79;

Dziękuje jak najpokorniej waszmość panu (służąca do szlachcica, II poł. XVIII w.) BohK2, 36;

Jak najniżej dziękuję (sługa do podstoliny, lata 80. XVIII w.) ZabF 114;

Dziękuję ci serdecznie mój Stanisławie (szlachcianka do ogrodnika, pocz. XIX w.) WójN 174;

Uniżenie dziękuję (hrabia do szlachcianki, pocz. XIX w.) NiemDom 64;

Mocno dziękuje (szlachcic do studenta, lata 20. XIX w.) PamEd 30;

Pokornie dziękuję (włóczęga do szlachcica, lata 20. XIX w.) PamEd 133;

Bardzo dziękuje panom (chorążyna do znajomych, lata 20. XIX w.) OlPam1, 220;

Bardzo panu prezesowi dziękuję (szlachcic, I poł. XIX w.) KorzKol 99; 
Ślicznie dziękuję pani (chłopka do szlachcianki, I poł. XIX w.) KorzOk 77;

Dziękuje pani bardzo (mieszczanin do wdowy, poł. XIX w.) KraszDz 286;

Bardzo dziękuję jaśnie wielmożnemu panu (rządca do dziedzica, poł. XIX w.) KraszDwa 362;

Bardzo paniom dziękuje (doktor do mieszczek, poł. XIX w.) KraszDz 318;

Serdecznie hrabiemu dziękuję (syn plenipotenta, poł. XIX w.)KraszH 170.

Kolejnym zabiegiem wydłużającym, a tym samym zwiększającym wartość honoryfikatywną formuły, było powtórzenie czasownika performatywnego. Pierwsze dziękuję od drugiego oddzielano adresatywami lub okolicznikiem:

Dziękuję, pokornie dziękuję (książę Radziwiłł do szlachty, która obiecała mu wierność, II poł. XVIII w.) ChodźPam 105;

Dziękuje, och! bardzo dziękuję (kapitan do szlachcica, pocz. XIX w.) ChodźKon 232;

Dziękuję ci, stokroć dziękuję, kochany pułkowniku (generałowa, I poł. XIX w.) KorzWd 15;

Dziękuję ci, moje dziecię, dziękuję (starszy mąż do młodej żony, lata 40. XIX w.) KorzSt 124;

Dziękuje, ślicznie dziękuję panu (szlachcianka do dziennikarza, poł. XIX w.) KuczGodz 44;

Dziękuje panu, dziękuję (arystokratka do hrabiego, poł. XIX w.) KraszH 64;

Dziękuję ci, dziękuję (cechmistrz do mieszczki, poł. XIX w.) ŁozNoc 60.

Możliwa była także amplifikacja formuły przez dodanie po czasowniku performatywnym podziękowania pośredniego:

Dziękuję ci, mój Jakóbie, poczciwe w tobie serce i Bóg zapłać, a obdarz twoją żonę i dziatki zdrowiem i łaską (tracz do przyjaciela, pocz. XIX w.) WójSp 126;

Dziękuję ci, bracie. Bóg ci to nadgrodzi (mularz do szewca, I poł. XIX w.) DzierzS 120.

Podziękowania to językowy wyraz wdzięczności za otrzymane dobro i trzeba pamiętać, że wielkość tego dobra zwykle również ma wpływ na wylewność aktu. Omawiane formuły były najczęściej bezpośrednią reakcją na drobne przysługi ${ }^{3}$, stąd ich względna prostota. Sam czasownik performatywny nie wskazuje rang nadawcy oraz adresata i był stosowany zarówno w relacjach równorzędnych, jak i asymetrycznych. O statusie partnerów interakcji mogły natomiast świadczyć elementy obudowy etykietalnej: formy atrybutywne i okoliczniki, przy czym trzeba pamiętać o ich silnej już leksykalizacji w badanym okresie.

Podobnie wyglądały podziękowania, które były konwencjonalną reakcją na inne akty grzecznościowe:

Bardzo dziękuje, nie pijam (mieszczka do regenta w reakcji na poczęstunek, lata 40. XIX w.) RusWar3, 215;

${ }^{3}$ Szczegółowe omawianie uwarunkowań sytuacyjnych każdego z przedstawianych tu aktów nie wydaje się być celowe, gdyż nie wnosi niczego istotnego. 
Dziękuje paniom, zdrowa jestem (naczelnikowa do znajomych pań pytających o jej zdrowie, poł. XIX w.) KorzRep 9;

Bardzo dziękuję, nie pijam herbaty (lekarz do rządcy, poł. XIX w.) KraszJary 72;

Mocno dziękuję (kobieta do dziennikarza zapraszającego, by usiadła, poł. XIX w.) KuczGodz 423.

\section{2. „DZIĘKUJĘ ZA”}

\subsubsection{W rozmowach}

W zebranym materiale podziękowania realizujące ten szablon są najliczniej reprezentowane. Określanie przyczyny podziękowania sprawia, że formuła wydłuża się i rośnie siła illokucyjna aktu. Drugim powodem nazywania bodźca jest odwołanie się do jakiejś przeszłej sytuacji, której dotyczy podziękowanie. Standardowymi elementami obudowy tych aktów są formy adresatywne oraz okoliczniki ograniczone do konwencjonalnych bardzo oraz serdecznie:

Bardzo panom dziękuję za ich uprzejmość (major do żołnierzy, poł. XVIII w.) RzewMich 104,

Bardzo państwu dziękuje za te dowody ich życzliwości (starosta do szlachty, II poł. XVIII w.) RzewLis2, 48;

Dziękuję Waszmość pani za otwartość szczerą (szlachta, II poł. XVIII w.) WójDw 108;

Dziękuje za dobre serce (guwerner do przyjaciela, II poł. XVIII w.) BohK1, 171;

Dziękuję za łaskawą obietnicę (służąca do pana, II poł. XVIII w.) BohK2, 26;

Dziękuje dobrodzice za łaskawe serce (kwestarz do szlachcianki, II poł. XVIII w.) ChodźPam 162;

Bardzo waćpanu dziękuję za te pobożne życzenia jego (podsędkowa do przyjaciela, II poł. XVIII w.) BDr 101;

Serdecznie JW Pani Dobrodziejce dziękuję za Jej pamięć o moich imieninach (kasztelanowa do znajomej, II poł. XVIII w.) LisKos 78;

Dziękuję ci, panie hrabio, serdecznie $z a$ to (żona do męża, pocz. XIX w.) WójN 239;

Dziękujemy panie Michale za smaczne sucharki do kawy (szlachta, pocz. XIX w.) ChodźKon 176;

Dziękuję ci za twoją życzliwość dla nich (szlachcianka do kupca, pocz. XIX w.) PamFel1, 156; 
Bardzo dziękuję za pamięć o pannie kasztelance (szlachcianka do znajomego, I poł. XIX w.) SkarbSt 24;

Dziękuje ci za twoje dobre serce (kapitan do siostrzeńca, I poł. XIX w.) ŁozHis 145 ;

Dziękuje panu za to serdecznie (młody szlachcic do starego żołnierza, I poł. XIX w.) KorzKol 116;

Dziękuje zacnej pani za słowo łaskawe (młody szlachcic do sędziny, I poł. XIX w.) KorzKom 345;

Bardzo dziękuję za ten honor (Żyd do szlachcianki, I poł. XIX w.) KorzKol 53;

Dziękuje panu za objaśnienie (student do podoficera, 1830) LewPam 36;

Dziękuje wam za przywiązanie (szlachcic do chłopów, lata 30. XIX w.) OrWęd 212;

Dziękuję pani za wyborny pomysł (baronowa do znajomego, lata 40. XIX w.) RusWar4, 29;

Dziękuje ci za troskliwość twoją (uboga kobieta do szlachcianki, lata 40. XIX w.) OsP2, 53;

Dziękuję za komplement (szlachta, poł. XIX w.) KraszDwa 384;

Bardzo ci dziękuję za twoje dobre serce (arystokratka do męża, poł. XIX w.) KraszH 146;

Dziękuję, mój dobry panie, $z a$ przestrogę i za pociechę (ślusarz do mieszczanina, poł. XIX w.) ŻmPow1, 281;

Dziękuję $z$ całego serca $z a$ wszystko dobre, którem pani nieznajomego obdarzyć raczyłaś, $z a$ wszystkie starania i za opiekę (szlachcic do córki leśniczego, lata 60. XIX w.) CieszP 285.

W ekscerpowanych tekstach zdarzają się także formuły z szykiem przestawnym, w których najpierw podawana jest przyczyna podziękowania, a dopiero potem czasownik performatywny:

$\mathrm{Za}$ dobre serce dziękuję wam dziatki (pan do chłopów, II poł. XVIII w.) BohK2, 269;

Uniżenie mu $z a$ ten wzgląd łaskawy dziękuję (wdowa do szlachcica, II poł. XVIII w.) CzarKom 282;

$Z a$ dobre chęci dziękuję (major do siostry, I poł. XIX w.) FrDz1, 217;

$Z a$ panią Kajetanową najpokorniej dziękuję (szlachcianka do znajomej, poł. XIX w.) ŻmPow2, 24.

\subsubsection{W listach}

W ekscerpowanej korespondencji typ ten jest zdecydowanie najczęściej używanym schematem podziękowania w całym badanym okresie. Wynika to zapewne z faktu, że w przypadku komunikacji listownej zwykle konieczne jest wyjaśnienie, czego wyrazy wdzięczności dotyczą - inaczej niż w kontaktach ust- 
nych, gdzie możliwa jest natychmiastowa reakcja na wyświadczoną przysługę. Omawiane formuły epistolarne identycznie jak w przypadku aktów oralnych były bardzo uniwersalne - pisano tak do równych sobie, ale także wtedy, gdy adresat posiadał niższą lub wyższą rangę pragmatyczną:

Dziękuje serdecznie JW Panu Dobrodziejowi za tę myśl (kasztelanowa do brata, 1763) LisKos 31;

Serdecznie dziękuję za atencją WMPana, którą tak z odebranego listu, jako i z wyczytanych w nim interesów doznaję z ukontentowaniem (Ignacy Krasicki do brata, 1766) KKor1, 138;

Dziękuję za przyłączoną mowę Króla Jegomościa (Ignacy Potocki do sekretarza KEN-u, 1774) KorPot 12;

Dziękuję za wiadomość o ubogaceniu biblioteki mojej (Stanisław August Poniatowski do Adama Naruszewicza, 1776) KorNar 58;

Dziękuję za skąpanie w winie węgierskim (Ignacy Krasicki do brata, 1781) KKor2, 33;

Na koniec dziękuję i za książkę (Stanisław August Poniatowski ${ }^{4}$ do Ignacego Krasickiego, 1780) KKor1, 416;

Serdecznie Ci dziękujemy wszyscy za nowiny (Jan Śniadecki do znajomego, 1788) ŚniaLis 9;

Dziękuje Ci za użyczone mi o pozostałych dzieciach szczegóły (arystokratka do przyjaciółki, 1789) TańDzien 156;

Jak najserdeczniej dziękuję JWWPanu za uwiadomienie o śmierci Cesarskiej (ciotka do marszałka, 1790) LisKos 217;

Dziękuje WPanu za wszystkie WPana oświadczone łaski (Hugo Kołłątaj do barona, 1792) KołLis 1, 28;

Dziękuję ci za wszystkie życzenia (hrabina do Jana Śniadeckiego, 1802) LM 147;

Dziękuję WPanu za wspomnienie o moich dziełach (Hugo Kołłątaj do współpracownika, 1806) KołCzac 121;

Czule dziękuję za udzielenie rady w przedmiocie gimnazjum (Tadeusz Czacki do Hugona Kołłątaja, 1806) KołCzac 86;

Bardzo Ci dziękuję za tak przyjemną korespondencją (autor sztuk do aktora, 1807) AktoPodr 65;

Bardzo dziękuję za przysłaną mi żywność i bydło (generał do pułkownika, 1812) PamWoj 193;

Dziękuje Ci najmocniej i najserdeczniej za Twoją czynną i prawdziwie przyjacielską gorliwość o moje interesa (oficjalista Potockich do przyjaciela, 1817) ChrzPam 175;

${ }^{4}$ Cytowana formuła świadczy o zerwaniu z wcześniejszą zasadą, że król nigdy nie „dziękował” tylko „wdzięcznie przyjmował” - choć być może na taką postać formuły wpłynął również fakt, że nie jest to korespondencja oficjalna. M. Cybulski, Obyczaje językowe..., s. 198-199. 
Dziękuje tobie za lakoniczne doniesienie (Adam Mickiewicz do Józefa Jeżowskiego, 1820) KorFil 100;

Dziękuje Panu za wszystkie dowody przyjaźni jego (Salomea Słowacka do Antoniego Odyńca, 1827) LisRS 249;

Ślicznie dziękuję za autografy i proszę o więcej (Maria Wodzińska do Fryderyka Chopina, 1836) ChopKor 1, 291;

Dziękuję Ci za pamięć o mnie (Wincenty Pol do znajomego, 1838) LisPol 32 ;

Dziękuję od serca za życzliwość i tak wielką przysługę (Wincenty Pol do znajomego, 1839) LisPol 40;

Najwdzięczniej dziękuję za te starania o interes mój (Józef Kraszewski do przyjaciela, 1839) KraszLis 92;

Dziękuje wam najszczerzej za obiecane dzieła (Seweryn Goszczyński do wydawcy, 1843) GoszLis 158;

Dziękuję za ten dowód przyjaźni i życzliwości (lekarz do przyjaciółki, 1849) MorLis 134;

Dziękuję Ci za uczucie wyrozumiałej sprawiedliwości w sprawie Towiańskiego (zakonnik do współbrata, 1849) LisDuń 25;

Dziękuje Tobie za Twoją stałą pamięć (Adam Mickiewicz do przyjaciółki, poł. XIX w.) MicKon 40;

Dziękuję za dobroć waszą (guwernantka do chlebodawców, poł. XIX w.) DmNa 230;

Naprzód ci serdecznie dziękuję za przysłany paltocik (Józef Kraszewski do brata, 1853) KraszLis 244;

Dziękuje bardzo za szczegóły mi dane o domie i interesach (Elżbieta Krasińska do plenipotenta, 1854) KrasLis 263;

Serdecznie dziękuję za mały list (Paulina Wilkońska do Władysława Syrokomli, 1856) WilkWsp 273.

W przypadku, gdy nadawca posiadał dużo niższy status społeczny od adresata, wyznacznikiem relacji asymetrycznej zwykle stają się wyrażenia okolicznikowe (często w stopniu najwyższym) oraz formy adresatywne w postaci rozbudowanych grup imiennych:

$\mathrm{Za}$ doniesienie mi wiadomości o panu Obreskow jak najpokorniej dziękuje WKMci (Ksawery Branicki do Stanisława Augusta Poniatowskiego, 1768) KonfB 94;

Za konferowanie pułku Panu Byszewskiemu z jak najgłębszym respektem dziękuję WKMci (Ksawery Branicki do Stanisława Augusta Poniatowskiego, 1768) KonfB 66;

Dziękuje wielce JWP Dobrodziejowi za obiecane mi przysłanie korespondencji (Adam Naruszewicz do starosty żmudzkiego, 1773) KorNar 7;

Dziękuję najjaśniejszemu majestatowi za tę godność (Adama Naruszewicz do Stanisława Augusta Poniatowskiego, 1781) NarLis 490; 
Jako najpokorniej dziękuję JWP Dobrodziejowi za pozwolenie awansowania pieniędzy dla mnie na kolaskę (plenipotent dóbr do Ignacego Potockiego, 1782) KorPot 126;

Dziękuje jak najuprzejmiej i jak najpokorniej WKM za pocieszenie tych sierot (Adam Naruszewicz do Stanisława Augusta Poniatowskiego, 1795) KorNar 480.

Zdecydowanie częściej niż w przypadku aktów oralnych obserwujemy szyk przestawny:

Za dokładne uwiadomienie mnie o czynnościach Komisji dziękuję (Ignacy Potocki do sekretarza KEN-u, 1775) KorPot 18;

Za pamięć JW Pani Dobrodziejce w imieniu moich serdecznie dziękuję (kasztelanowa do znajomej, 1786) LisKos 178;

Za udzielone wiadomości o życiu i zdania o pracach uczonych Czecha najmocniej dziękuję (Euzebiusz Słowacki do Jana Śniadeckiego, 1811) LisRS 19;

$Z a$ pozostawienie mi jazdy bez zmian bardzo generałowi dziękuję (generał do generała, 1812) PamWoj 210;

Za przestrogę dziękuję (Salomea Słowacka do Antoniego Odyńca, 1827) LisRS 179;

$Z a$ wełnę przysłaną najpokorniej $\mathrm{Ci}$, luby Panie, dziękuję (ziemianka do przyjaciela, 1832) LisRS 400;

Mój najmilszy, raz jeszcze za twój list Ci dziękuję (Narcyza Żmichowska do brata, 1838) ŻmLis1, 63;

Za książki bardzo dziękuje (Seweryn Goszczyński do przyjaciela, 1839) GoszLis 69;

Za poczciwe zaprosiny Twoje do Górki, dziękuje Ci (Wincenty Pol do przyjaciela, 1840) LisPol 47;

Za otrzymane dzieła całem sercem dziękuję (Stanisław Trentowski do przyjaciela, 1841) TrenLis 34;

Ci serdecznie za pamięć Twoją o nas dziękuję (Józef Kraszewski do brata, 1845) KraszLis 124;

Raz jeszcze $z a$ twe złote serce ku mnie ci dziękuje (Zygmunt Krasiński do przyjaciela, 1846) KrasMał 47;

Za tabakę i kalendarz dziękuję (lekarz do przyjaciół, 1849) MorLis 133;

$Z a$ wiadomość o mieszkaniu Bronka dziękuję Ci najmocniej (Teofil Lenartowicz do przyjaciela, 1851) LisLen 28;

$\mathrm{Za}$ obietnicę dla mojego „Kwestarza” jak najserdeczniej dziękuję (Adam Pług do Pauliny Wilkońskiej, 1852) WspWilk 1852. 
Drugim typem formuł, w których również wyjaśniano przyczynę podziękowań, były wypowiedzi ze zdaniem podrzędnym dopełnieniowym. Schemat ten w badanym materiale występuje jednak znaczniej rzadziej niż dziękuję za. Wydaje się, że pierwotnie szablon ten był typowy dla epistolografii, a dopiero z czasem zaczęto go używać również w kontaktach bezpośrednich. Świadczy o tym fakt, że w przypadku korespondencji większość odnotowanych użyć pochodzi z wieku osiemnastego, natomiast w funkcji formuł oralnych tego rodzaju frazy na większą skalę pojawiają się dopiero w następnym stuleciu:

Dziękuję waści, księże kwestarzu, żeś moją obligację tak rychło i ochoczo spełnił (starosta do kwestarza, II poł. XVIII w.) ChodźPam 141;

Bardzo dziękuje, żeś mnie pan raczył w dniu dzisiejszym odwiedzić (szlachcic do grafa, lata 20. XIX w.) OlPam1, 313;

A, dziękuję ci, żeś mi przypomniał (szlachcic do Kajetana Koźmiana, pocz. XIX w.) KoźPam2, 255;

Dziękuję ci, mój drogi Erazmie, żeś chęci mojej dogodził (żona do męża, I poł. XIX w.) KorzDz 52;

$\mathrm{O}$, dziękuję ci, kasztelanicu, żeś o mnie pamiętał (starościna, I poł. XIX w.) KorzKom 223;

Szczerze wam dziękuję, że mi ufacie (łowczy do przyjaciół, I poł. XIX w.) KorzDram 12;

Dziękuję pani, żeś tak łaskawie przyjęła wiernego towarzysza podróży (szlachta, I poł. XIX w.) KorzKol 11;

Dziękuję ci, żeś mnie cokolwiek rozerwał (szlachcic do Żyda, I poł. XIX w.) KorzKol 57;

Dziękuję ci pułkowniku, że dla mojej rozrywki chcesz nawet wstręt swój przezwyciężyć (hrabina do pułkownika, I poł. XIX w.) KorzWd 77;

Dziękuję ci Jędrzeju, żeś mnie trochę przewiózł (panienka do służącego, lata 40. XIX w.) DzierzD2, 60;

Dziękuję ci, że się dobrze uczysz i sprawiasz mi pociechę (matka do syna, lata 40. XIX w.) CieszT1, 155;

Panie Tomaszu, dziękuję wam stokrotnie, żeście zachowali tajemnicę (cechmistrz do ubogiego szlachcica, poł. XIX w.) ŁozNoc 63;

Bogu naprzód, potem tobie dziękuje, że cię jeszcze zobaczę i posłyszę (ojciec do córki, poł. XIX w.) KraszH 288;

Dziękuję ci żeś o mnie pamiętała (ciotka do siostrzenicy, poł. XIX w.) BujSt 234;

Dziękuję ci, żeś o mej prośbie pamiętał (żona do ślusarza, poł. XIX w.) ŻmPow1, 235; 
Dziękuje ci, Urszulko moja, bardzo serdecznie ci dziękuje, że w ten sposób moją sprawę przedstawiasz (arystokratka do przyjaciółki, poł. XIX w.) ŻmPow2, 154.

Formuły te z racji swej długości sprawiają wrażenie dość ceremonialnych, szczególnie, gdy dodatkowo obudowane są adresatywami i okolicznikami. Według M. Marcjanik akty tego typu stosowane są wówczas, gdy nadawca uważa, że działanie odbiorcy znacznie przekroczyło jego towarzyskie obowiązki ${ }^{5}$.

W listach formuły te są rzadziej spotykane niż w przypadku konwersacji i używane wyłącznie w relacjach symetrycznych:

Dziękuję, że moja myśl zgodziła się z myślą tak JW Pana, jako i JW Wojewodzica Poznańskiego (kasztelanowa do starosty, 1773) LisKos 152;

Dziękuję Pani mojej, żeś raczyła odpieczętować list od Święcickiego (arystokrata w liście do starościny, 1792) SzymLis 54;

Bardzo dziękuję Panu mojemu, żeś mię użyć chciał do usłużenia sobie w interesie przyjacielskim (przyjaciel do Franciszka Karpińskiego, 1799) KarpKor 103;

Dziękuję, że się to stało za pośrednictwem Pańskim (literat do znajomego, 1842) KorGrab1, 105.

\section{4. „SKŁADAM DZIĘKI” I PRZEKSZTAŁCENIA}

\subsubsection{W rozmowach}

W celu zwiększenia mocy illokucyjnej aktu możliwe było zastąpienie konstrukcji syntetycznej dziękuje przez analityczną sktadam dzięki. Charakterystyczną cechą omawianych tu podziękowań jest bardzo duża wariantywność formalna. Formuła zbudowana z czasownika performatywnego skladam oraz z biernika liczby mnogiej rzeczownika $d z i e ̨ k$ pojawia się w ekscerpowanych tekstach jedynie kilka razy:

Najpokorniejsze składam dzięki panu generałowi za łaskę jaką zaszczycasz (uboga szlachcianka, poł. XVIII w.) RzewMich 39;

Składam najgłębsze dzięki najjaśniejszemu królowi, panu memu i tobie JW pani Dobrodziejce z najczulszem uczuciem dozgonnej mojej wdzięczności (kanonik do hetmanowej, kon. XVIII w.) PamGąs 62;

To dobrodziejstwo przyjmuję i przy nogach twoich dzięki ci za nie składam (służąca do hrabiego, I poł. XIX w.) KorzDram 275.

Akty te miały bogatą obudowę grzecznościową, były długie, co decydowało o ich podniosłym charakterze. Kierowano je do osób stojących wyżej w hierarchii społecznej od nadawy.

\footnotetext{
${ }^{5}$ M. Marcjanik, Polska grzecznosśc..., s. 207.
} 
Przekształcenia formuły polegały najczęściej na zastępowaniu składam czasownikami typu oświadczam, niosę, winienem oraz na wprowadzaniu rzeczowników pokrewnych do dzięki: dziękczynienie, podziękowanie, podzięka:

Najuniżeńsze składam dziękczynienie wielmożnemu panu i waszmość państwu, mnie wielce miłościwym braciom i dobrodziejom (marszałek przemawiając do szlachty, II poł. XVIII w.) SkarbDod 131;

W imieniu generalności oświadczam WPanu podziękowanie (wódz wojska do szlachcica, II poł. XVIII w.) RzewLis2, 188;

I waspanu tez za to dzięki zanosiemy, ześ nas pogodził (furman do organisty, kon. XVIII w.) BoCu 131;

$\mathrm{Z}$ całego serca niosę dzięki gorliwości waszej (wojewodzic do generała, I poł. XIX w.) KorzKom 236;

Winnam ci wiele podziękowania, Szloma (szlachcianka do Żyda, I poł. XIX w.) KorzKol 178.

Sposobem na zwiększenie wartości honoryfikatywnej podziękowania było wprowadzenie orzeczenia modalnego:

Winnam panu staroście ponowić moje dzięki, za dar coś mi go pan raczył przysłać na pamiątkę (szlachcianka do starosty, II poł. XVIII w.) RzewLis1, 142.

Używano też syntetycznych i analitycznych form trybu rozkazującego:

Pozwól, niech u nóg złożę twych najczulsze dzięki (szlachcic do ojca narzeczonej, dziękując za zgodę na małżeństwo, kon. XVIII w.) NiemPowr 81;

O mój arcy szanowny kolego! przyjmij najserdeczniejszą podziękę którą ci tu naprzód już imieniem p. Plater składam (ułan do oficera, I poł. XIX w.) PamUł 136;

Chciej przyjać moje dzięki i niskie ukłony (hrabianka do szlachcica, I poł. XIX w.) NiemPod 65;

Dzięki niechaj wam będa, ojcze, za słowa pocieszenia (szlachcianka do zakonnika, lata 30. XIX w.) SkarbTar 36.

Formuły te miały duża siłę illokucyjną i dlatego stosowano je przede wszystkim wtedy, gdy dziękowano za duże przysługi oraz w sytuacjach oficjalnych.

W ekscerpowanych dziewiętnastowiecznych tekstach znajdujemy również akty, które utraciły wykładnik predykacji - składam dzięki bywało skracane do popularnego i dziś $d z i e ̨ k i{ }^{6}$. W dobie średniopolskiej dzięki nie mogło występować samodzielnie, bez żadnego epitetu ${ }^{7}$, natomiast w badanym okresie często spotykamy formuły pozbawione okolicznika. Najwyraźniej jednak samo dzięki nadal

${ }^{6}$ Według K. Ożoga dzięki ma pochodzić od konstrukcji wyrażam słowa podzięki, jednak badany materiał w żaden sposób nie potwierdza tej tezy. K. Ożóg, Podziękowania w polszczyźnie mówionej, „Język Polski” 1982, R. LXII, z. 4/5, s. 261.

${ }^{7}$ M. Cybulski, Obyczaje językowe..., s. 197. 
było uważane za zbyt zdawkowe i w celu zwiększenia grzeczności tych formuł dodawano formy adresatywne. Siłę illokucyjną aktów zwiększano też przez powtarzanie dzięki:

Dzięki panom, dzięki (kapitanowa do szlachciców, pocz. XIX w.) ChodźKon 261;

Dzięki! dzięki szlachetny panie Władysławie (córka szewca do poety, I poł. XIX w.) DzierzS 134;

Dzięki! dzięki wam najszczersze (Kornel Ujejski do młodzieży, I poł. XIX w.) BrzostCK 25;

Dzięki ci, dzięki stryjaszku, mój drogi (szlachta, I poł. XIX w.) FrDz1, 353;

Dzięki ci pani (szlachcic do przyszłej teściowej, lata 40. XIX w.) RusWar4, 211;

Dzięki ci młody aniołku (szlachcic do panienki, lata 40. XIX w.) DzierzD2, 32;

Dzięki tobie, dzięki piękna dziewico (szlachta, lata 40. XIX w.) OsP1, 176;

Serdeczne dzięki (pianistka do hrabiego, poł. XIX w.) KraszH 273;

Dzięki ci, Julianie (szlachta, poł. XIX w.) KraszDwa 37.

O ile konstrukcje analityczne zawierające $d z i e ̨ k i$ miały ceremonialny charakter, to cytowane powyżej podziękowania są go pozbawione. Akty te funkcjonowały podobnie jak dziękuję i tak samo jak formuly z czasownikiem performatywnym mogły też być amplifikowane przez dodanie wyjaśnienia, czego wyrazy wdzięczności dotyczą:

Dzięki tobie bracie za myśl zbawienną ofiarowania Bogu tego votum (zakonnik do współbrata, pocz. XIX w.) ChodźPam 196;

Dzięki wam $z a$ wasze pozdrowienia (ubogi szlachcic do starościca, I poł. XIX w.) SkarbDod 103;

Dzięki, Gustawie, za twoje rozkazy (szlachta, I poł. XIX w.) FrDz1, 449;

Dzięki wam $z a$ waszę gościnność (arystokrata do szlachty zagrodowej, lata 30. XIX w.) SkarbTar 165;

Dzięki ci panie Karolu za opiekę nad tym biednym chłopem (szlachcianka do znajomego, lata 40. XIX w.) DzierzD1, 113.

\subsubsection{W listach}

W epistolografii wariantywność formuł w porównaniu z podziękowaniami ustnymi jest mniejsza i łatwiej znaleźć tutaj akty szablonowe:

Składam Ci, Panie, dzięki za wyrazy, które z uszanowaniem co dzień odczytuję sobie (sekretarz do Ignacego Potockiego, 1792) TKor 36;

$\mathrm{Z}$ uszanowaniem składam winne dzięki za łaskawą pamięć o mnie w listach do w. komisarza (sekretarz do Ignacego Potockiego, 1792) TKor 43;

\footnotetext{
${ }^{8}$ Synchronicznie dzięki jest odczuwane jako skrót od dziękuję. K. Ożóg, Podziękowania...,
} s. 261. 
Za dane mi rozkazy jak najżywsze Pani mojej składam dzięki (arystokratka do starościny, 1795) SzymLis 84;

Dzięki czułe składam za zajęcie się moim statutem (Tadeusz Czacki do Hugona Kołłątaja, 1806) KołCzac 179;

Składam JWW Panu Dobr. dzięki za przysłane mi uwagi nad pismami moimi (Euzebiusz Słowacki do Jana Śniadeckiego, 1811) LisRS 22;

$\mathrm{Za}$ to, żeś do mnie pisał $\mathrm{w}$ takiej godzinie, najczulsze ci dzięki składam i czuję prawdziwą wdzięczność (Zygmunt Krasiński do przyjaciela, 1838) KrasPot 44;

Dzięki składam za ciagge donoszenie o Ojcu (Zygmunt Krasiński do plenipotenta, 1856) KrasLis 125;

Za rysunki i fotografie dzięki Ci sktadam (Józef Kraszewski do Teofila Lenartowicza, 1858) LenarKor 28.

Mechanizmy przekształceń formuł listownych są podobne do tych, które obserwujemy w podziękowaniach ustnych:

Jak najżywsze oświadczam podziękowanie takową uczynność pomiędzy inne statecznej JWWMPana łaskawości i przyjaźni licząc dowody (Ignacy Krasicki do kasztelana, 1767) KKor1, 162;

Składam za nią pokorne dziękczynienie (Adam Naruszewicz do starosty żmudzkiego, 1773) KorNar 18;

Niose powinne podziękowanie JWWMP Dobrodziejowi za łaskawe przyjęcie dawniejszej prośby mojej (kantor krakowski do Ignacego Potockiego, 1787) KorPot 156;

Z pokorą głęboką dzięki czynię za najdroższe mi zawsze ręki i serca Jego wyrazy (Adam Naruszewicz do Stanisława Augusta Poniatowskiego, 1788) KorNar 294;

$\mathrm{Z}$ uszanowaniem powinne niosę dzięki za łaskawe wyrazy JW Pana (sekretarz do Ignacego Potockiego, 1792) TKor 63;

Odebrałem łaskawą pamięć JW Pana Dobrodzieja, za którą najniższe zasytam podziękowanie (Tadeusz Kościuszko do wielkiego księcia litewskiego, 1792) KośWsp 33;

Przyjmij, Pani moja, najżywsze $d z i e ̨ k i$ za listek Twój i za pomarańcze (arystokrata do starościny, 1796) SzymLis 90;

Przesyłam czułe dzięki za wszystkie łaskawe wyrazy (arystokrata do starościny, 1798) SzymLis 99;

Najżywsze oświadczam mu podziękowanie za udzielone mi uwagi (Euzebiusz Słowacki do Hugona Kołłątaja, 1806) KołCzac 154;

Pozwól Pan złożyć sobie największe dzięki za uprzejmą pomoc w projektowanej przezemnie publikacji „Źródel” (literat do kolegi, 1842) KorGrab1, 54;

Zawsze winienem Panu największe dzięki za tak doskonałe biuletyny literackie (literat do kolegi, 1842) KorGrab1, 87;

Zasyłam Panu najszczersze podziękowania (Elżbieta Krasińska do plenipotenta, 1854) KrasLis 258. 
Choć podziękowania te miały wysoką wartość honoryfikatywną ze względu na swoją długość i bogatą obudowę etykietalna, to w badanym okresie w dużej mierze mają jedynie konwencjonalny charakter, skoro nie jest widoczna zależność między ich użyciem a statusem nadawcy i odbiorcy.

W dziewiętnastowiecznych listach do osób równych rangą nadawcy lub od niego niższych chętnie stosowano formuły pozbawione czasownika:

Dzięki Panu memu kochanemu i szanownemu za przesłane książki (Ignacy Potocki do Tadeusza Czackiego, 1806) KorPot 234;

Dzięki mężowi JW Pani Dobrodziejki, że nie zapomina dawnych przyjaciół i towarzyszów broni (generał do żony kolegi, 1809) ZałWsp 149;

Z sakiewki kontenta jestem i dzięki Panu (Salomea Słowacka do Antoniego Odyńca, 1827) LisRS 266;

Dzięki Ci tysiączne za to wszystko, coś kiedy dla mnie, nieszczęśliwego przyjaciela uczynił (Wincenty Pol do przyjaciela, 1830) LisPol1, 21;

Dzięki ci, kochana matko za wszystko, co robisz dla syna (Juliusz Słowacki do matki, 1831) KorSł 19;

Teofilu, Hersylko, dzięki wam za wasze słowa w liście (Juliusz Słowacki do matki, 1833) KorSł 167;

Dzięki Ci za Twe uprzejme słowa przyjaźni i pociechy (Joachim Lelewel do znajomego, 1835) LelNie 53;

Dzięki ci, dzięki mój Edwardzie, że tak myślisz o mnie (Zygmunt Krasiński do przyjaciela, 1835) KrasJar 13;

Nieskończone dzięki za pieniądze (Seweryn Goszczyński do przyjaciela, 1838) GoszLis 29;

Dzięki Tobie serdeczne, tysiączne, łez pełne i dzięki za wszystko, ale najbardziej za tę obrączkę włosów (Zygmunt Krasiński do Delfiny Potockiej, 1839) KraDel 10;

Dzięki ci za twój list (Zygmunt Krasiński do przyjaciela, 1841) KrasMał 2;

Dzięki Ci, kochany Teofilu, za przypis „Świętej pracy” (Józef Kraszewski do Teofila Lenartowicza, 1858) LenarKor 27;

Dzięki panu za podjęte trudy (Zygmunt Krasiński do plenipotenta, 1858) KraLis 251 ;

Najserdeczniejsze dzięki za troskliwość o mnie Ojcowską (Józef Kraszewski do ojca, 1859) KraszLis 419.

Ciekawym indywidualizmem Zygmunta Krasińskiego była często spotykana w jego listach fraza, w której biernik rzeczownika dzięk został zastapiony dopełniaczem:

Tysiqc dzięków Ci za Balladynę składam (do Delfiny Potockiej, 1840) KrasDel 39;

Tysią dzięków za twój drugi list, z serca ci dziękuję (do przyjaciela, 1841) KrasMał 1841;

Tysiq̨c najserdeczniejszych dzięków za codzienne do mnie pisanie (do plenipotenta, 1855) KrasLis 106. 
To, co odróżnia wszystkie omawiane tu formuły epistolarne od ustnych, to obowiązkowe wyjaśnienie, czego dotyczy podziękowanie. Najczęściej jest ono wprowadzane tak samo jak w przypadku aktów z performatywem dziękuję: przeważa konstrukcja $d z i e ̨ k i ~ z a$, pojawiają się także wypowiedzenie złożone.

\section{5. „PROSZĘ PRZYJĄĆ/RACZ PRZYJĄĆ PODZIĘKOWANIA” ITP.}

Użycie takich ceremonialnych formuł podziękowań obudowanych aktem prośby lub czasownikiem honoryfikatywnym raczyć było rzadkie i ograniczone do komunikacji listownej. Chociaż akty te miały dużą wartość grzecznościową, to znajdujemy je nie tylko w listach do osób wyższych rangą od nadawcy:

Za zaczęty diariusz podróży proszę przyjąć wyraz najczulszej wdzięczności (arystokrata do starościny, 1796) SzymLis 92;

Za przywrócenie P. Januszewskiego na jego miejsce racz JO Wasza Księca Mość przyjąć najpokorniejsze podziękowanie, które w imieniu całej familii mam honor złożyć (August Bécu do księcia Adama Czartoryskiego, 1819) LisRS 36;

Racz Pan przyjać zapewnienia mej wdzięczności i uszanowania z jakim zostaję do zgonu najprzywiązańszym uczniem (Fryderyk Chopin do swego dawnego nauczyciela, 1831) ChopKor1, 207;

Za tak łaskawe przyjęcie listu mego racz Szanowny Pan Dobrodziej przyjać najszczersze podziękowania (Wincenty Pol do znajomego, 1843) LisPol 109;

Racz przyjać wyraz najszczerszy i najgłębszy dziękczynienia mego (Zygmunt Krasiński do przyjaciela, 1847) KraSł 132;

Proszę Pana przyjać me szczere podziękowanie za wszystko (Elżbieta Krasińska do plenipotenta, 1854) KrasLis 261;

Prosze przyjać me podziękowania i najszczersze życzenia zdrowia jak najlepszego (Elżbieta Krasińska do plenipotenta, 1855) KrasLis 271.

\section{6. „JESTEM WDZIĘCZNY/OBOWIĄZANY/OBLIGOWANY” I PRZEKSZTAŁCENIA}

\subsubsection{W rozmowach}

Tego rodzaju podziękowania pośrednie zaczęły rozpowszechniać się dopiero w początkach okresu nowopolskiego. W dobie średniopolskiej istniała, początkowo zarezerwowana tylko dla króla, formuła wdzięcznie przyjmujemy, która 
z czasem uległa deprecjacji i różnym przekształceniom ${ }^{9}$ Być może fraza jestem $w d z i e ̨ c z n y \mathrm{w}$ funkcji podziękowania jest również śladem po niej.

Najczęściej spotykana w ekscerpowanych tekstach postać formuły to jestem wdzięczny, przy czym często stosowano szyk przestawny:

Wielce wam koledzy wdzięczny jestem, żeście zbliżyli odwiedzenie mię przed siódmą godziną (Tadeusz Kościuszko do adiutantów, 1793) PamGąs 86;

Wdzięczna Waćpanu jestem, lecz taka zabawa, chociaż nie jest naganną, jednak mnie nie łudzi (szlachcianka do znajomego, kon. XVIII w.) NiemPowr 31;

Wdzięczny jestem Pani za tę ufność (pułkownik do generałowej, I poł. XIX w.) KorzWd 11;

Wdzięczny jestem pani i za tę miłą wzmiankę (wojewodzic do kasztelanki, I poł. XIX w.) KorzKom 179;

Ja najszczerzej jednak wdzięczny panu jestem i za to (szlachcic do znajomego, I poł. XIX w.) BrzostCK 75;

Bardzo panu wdzięczni jesteśmy (szlachta, lata 40. XIX w.) DzierzD1, 97;

Jestem ci wdzięczny za twoje zaufanie (szlachta, lata 40. XIX w.) RusWar2, 11 ;

Wdzięczny pani jestem niewymownie za dozwolenie odwiedzenia jej (hrabia do mieszczki, lata 40. XIX w.) RusWar3, 139;

Wdzięczna panu jestem, żeś mógł pamiętać o mnie biednej (arystokratka do hrabiego, poł. XIX w.) KraszH 64;

Wdzięczny jestem za łaskę pana dobrodzieja (bernardyn do szlachcica, poł. XIX w.) DmNa 332.

Czasami orzecznik przyjmował postać przymiotnika w odmianie prostej:

Wdzięczen jestem nieskończenie za dar, ale nade wszystko cenię pamięć pani (młody szlachcic do starszej damy, II poł. XVIII w.) PamOch1, 215;

Póki życia mego stanie, będę wdzięczen za to waszmość panu (uczeń do guwernera, II poł. XVIII w.) BohK1, 115;

$\mathrm{Z}$ duszy i serca panu dobrodziejowi jestem wdzięczen, żeś mnie sobie raczył przypomnieć (szlachcic do sąsiada, poł. XIX w.) KraszH 90.

W innym wariancie omawianej formuły forma mianownikowa orzecznika była zastępowana narzędnikową:

A! mój doktorze, wdzięcznq ci za nie jestem (księżna do lekarza, kon. XVIII w.) BolBez2, 56;

Odprawiasz mnie z nadzieją i dobrym słowem, za które z duszy ci jestem wdzięcznym (lekarz do ukochanej, poł. XIX w.) KraszDz 402;

Czynisz mi pan hrabia honor, na który nie zasłużyłam wcale, jestem mu wdzięczna za to (pianistka, poł. XIX w.) KraszH 273;

Wdzięczna jestem panu za przychylenie się do mojej instancji (szlachcianka do podczaszyca, poł. XIX w.) BujSt 100;

\footnotetext{
${ }^{9}$ M. Cybulski, Obyczaje językowe..., s. 199.
} 
Otrzymałam właśnie z poczty list pański z pożegnaniem i wdzięczna mu jestem bardzo, że pan na liście nie poprzestał (szlachcianka do gościa, lata 60 . XIX w.) CieszP 292.

Wielokrotnie możemy też w badanym materiale znaleźć formuły, w których temat czasu teraźniejszego czasownika być ulega redukcji, a uwolniona końcówka przyłączana jest do innych elementów formuły - zwykle do przysłówków, którymi chętnie obudowywano takie podziękowania:

Bardzom ci wdzięczny, moja panno (książę do szlachcianki, poł. XVIII w.) TańList 94;

Bardzom ci wdzięczna (szlachcianka do marszałka dworu, II poł. XVIII w.) CzarKom 269;

O, jakżem wdzięczna najjaśniejszemu panu (starościna do szambelana, I poł. XIX w.) KorzKom 173;

Za twoje serce, ciociu, wdzięcznam ci stokrotnie (szlachta, I poł. XIX w.) KorzKom 316;

Serdeczniem ci wdzięczny, moja Jadwisiu (mąż do żony, I poł. XIX w.) KorzDz 51;

Bardzom pani wdzięczny (szlachcic do znajomej, I poł. XIX w.) KorzOk 30;

Jakżem ci wdzięczen (lekarz do znajomego, poł. XIX w.) KraszJary 20;

Wielcem wam wdzięczen za zaufanie (szlachta, poł. XIX w.) ŁozCh1, 98

Bardzom pani wdzięczen (mieszczanin do ochmistrzyni, poł. XIX w.) KraszDz 212.

Rolę orzecznika mogły pełnić także synonimiczne imiesłowy przymiotnikowe zobowiqzany/obligowany:

Wielce waćpanu jestem obligowana (panna do szlachcica, II poł. XVIII w.) CzarKom 99;

Obligowana waćpanu jestem (wdowa do szlachcica, II poł. XVIII w.) CzarKom 252;

Nieskończenie waćpanu dobrodziejowi obowiqzana jestem (panienka do swego opiekuna, II poł. XVIII w.) ZabDz1, 188;

Bardzo ci obligowany jestem za takie przypomnienie (szlachcic do przyjaciela, kon. XVIII w.) PamGąs 23;

Bardzo jestem obowiazany baronowi za ten zaszczyt (regent, lata 40. XIX w.) RusWar3, 123;

Mocno jestem panu obowiązany (mieszczanie, poł. XIX w.) KuczGodz 9.

$\mathrm{W}$ analizowanych tekstach znajdziemy też indywidualnie przekształcone formuły, w których orzeczenie imienne zastępowane jest innymi konstrukcjami werbalnymi:

Wdzięcznością niewygasłą wypłacać się będę do zgonu waćpanu dobrodziejowi za tyle zlanego na mnie szczęścia (szlachta, kon. XVIII w.) CzarKom 410;

Największą mieć będę waćpani dobrodziejce za to obligacją (szlachcic do wdowy, kon. XVIII w.) CzarKom 258; 
Uszczęśliwiony związkiem dla mnie najpożądańszym, mam sobie za najpierwszą powinność upaść do nóg waszmość państwa dobrodziejstwa i oświadczyć tę wdzięczność, która przez całe życie moje będzie prawidłem wszystkich myśli moich i postępków (szlachcic do opiekunów narzeczonej, II poł. XVIII w.) BohK2, 181;

Owszem Mocia Dobr. należy mi być wdzięcznym pani, gdyż za jej pośrednictwem odkrytą została zbrodniarka (policyjny urzędnik do baronowej, lata 40 . XIX w.) RusWar4, 28;

Ileż to wdzięczności winnam panu (hrabina do lekarza, poł. XIX w.) KraszJary 88.

Omawiane tu akty etykiety miały dość uroczysty charakter i wyższą wartość honoryfikatywną niż te z czasownikiem performatywnym dziękuję. Przyczyną była nie tylko analityczna postać członu werbalnego, ale również bogata $\mathrm{w}$ adresatywy i intensyfikujące okoliczniki obudowa grzecznościowa formuł. Dodatkowo w większości tego typu aktów wyjaśniano przyczynę podziękowań, co wydatnie zwiększało jego długość. Zebrany materiał pokazuje, że to raczej właśnie ranga sprawy, za którą dziękowano, decydowała o wyborze takiej formuły, a nie status społeczny nadawcy i odbiorcy.

\subsubsection{W listach}

W porównaniu z formułami konwersacyjnymi w korespondencji częściej można spotkać akty szablonowe:

Wdzięczen jestem odezwy WM Pana i tej pieczy, którą o moich rzeczach upewniasz (Ignacy Krasicki do brata, 1763) KKor1, 73;

Wdzięczen bardzo jestem dobrego WmWM Pana serca, które mi okazujesz (Ignacy Krasicki do brata, 1767) KKor1, 158;

Za opis stanu diecezji wileńskiej wielce wdzięczen jestem WPanu (Stanisław August Poniatowski do Adam Naruszewicza, 1777) KorNar 69;

Bardzo wdzięczen jestem za zatrudnienie się ekspedycją mego gabinetu (Hugo Kołłątaj do znajomego, 1792) KołLis1, 113;

Nieskończenie wdzięczen jestem JW Panu za udzielenie mi jego dzieła (Jan Śniadecki do Hugona Kołłątaja, 1806) KołCzac 252;

Wdzięczen jestem za obdarzenie mnie swym pismem (filomata do kolegi, 1820) KorFil 175;

Wdzięczne Panu jesteśmy za propozycję posyłania kartek z naszych sztambuchów (Salomea Słowacka do Antoniego Odyńca, 1826) LisRS 151;

Wdzięczna jestem Panu za danie mi prawa obrania dnia na obchodzenie jego [imienin] (Salomea Słowacka do Antoniego Odyńca, 1827) LisRS 281;

Babuniu droga i dziaduniu wdzięczny wam jestem, że mnie jeszcze trochę kochacie (Juliusz Słowacki, 1832) KorSł 49; 
Wdzięczen jestem Panu za to pożyczenie (Adam Mickiewicz do hrabiego, 1832) KorMic 58;

Włosy twoje i babuni chowam święcie i wdzięczny ci jestem, matko droga, za ich przysłanie (Juliusz Słowacki, 1834) KorSł 181;

Wdzięczna Ci jestem za doniesienie mi cośkolwiek o Antosiu (Teresa Wodzińska do Fryderyka Chopina, 1836) ChopKor1, 289;

Wielce Ci wdzięczen jestem za list Twój, kochany Edmundzie (Wincenty Pol do przyjaciela, 1837) LisPol 25;

Łaskawa Pani Moja i Dobrodziko, bardzo wdzięczny jestem Pani za Jej pismo (lekarz do przyjaciółki, 1838) MorLis 33;

Bardzo ci wdzięczny jestem, że mnie ośmielasz co do mojej korespondencji (literat do Józefa Kraszewskiego, 1842) KorGrab2, 122;

Bardzo wdzięczna jestem Panu za spełnione komisa (Elżbieta Krasińska do plenipotenta, 1851) KrasLis 256.

W listach jedynie wyjątkowo pojawiają się akty, w których temat czasownika być jest zredukowany a końcówka przyłączona do okolicznika:

Bardzom ci wdzięczny za przysłanie mi listu od mojej siostry (Seweryn Goszczyński do przyjaciela, 1824) GoszLis 3;

Bardzom Ci wdzięczny za to wczesne doniesienie (Zygmunt Krasiński do plenipotenta, 1858) KrasLis 319.

Prawdopodobnie takie skracanie formuly, chętnie stosowane w kontaktach bezpośrednich, nie było zgodne $\mathrm{z}$ wymogami etykiety w przypadku korespondencji.

Typowo epistolarną osiemnastowieczną formułą był szablon oświadczam wdzięczność. Dzięki takiemu przekształceniu podziękowanie stawało się bardziej ceremonialne i było stosowane przede wszystkim w korespondencji oficjalnej:

Szczerą WMPanu oświadczam wdzięczność za doniesienie, o które prosiłem (Ignacy Potocki do profesora Szkoły Wydziałowej w Lublinie, 1781) KorPot1, 96;

Oświadczam zatem WPanu wdzięczność moją za tę pracę użyteczną społeczeństwu (Stanisław August Poniatowski do Franciszka Karpińskiego, 1792) KarpKor 56;

List Jego do JP Potockiego Marszałka, pisany, zawierając łaskawą o mnie pamięć i troskliwość [...] jest mi powodem do oświadczenia JW Panu najczulszej wdzięczności (Hugo Kołłątaj do Stanisława Małachowskiego, 1792) KołLis1, 69 - autor wprowadził jeszcze bardziej rozbudowaną konstrukcję, która ma wysoką wartość honoryfikatywną.

Obok aktów szablonowych w badanym materiale nie brak także indywidualnie przetworzonych formul:

Wdzięcznym przyjmuję sercem oświadczone JWWMP życzenia (Ignacy Krasicki do brata, 1766) KKor1, 136; 
Wiem dobrze, żem nie zasłużył na to, ażebym mógł mymi prośbami zatrudniać JWWMP Dobrodzieja, ale jego dobroć dla mnie, uprzedzająca zawsze zasługi, sposobnym mnie czyni do odsłużenia i oświadczenia tej wdzięczności, z którą jestem dozgonnie (Kazimierz Narbut do Ignacego Potockiego, 1783) KorPot 129;

Czuję zawsze wdzięczność za łaskę i przychylność we wszystkich okolicznościach okazującą się (Grzegorz Piramowicz do Ignacego Potockiego, 1785) KorPot 144;

Milion wdzięczności Dobremu Panu za jego życzliwe wyrazy (sekretarz do Ignacego Potockiego, 1793) TKor 130;

Wyrazy Pani mojej w liście przeniknęły mnie najżywszą wdzięcznością (arystokrata do starościny, 1795) SzymLis 86;

Wtedy dopiero wdzięczność moja się skończy, kiedy już serca mieć nie będę (Stanisław Trembecki do księcia, 1801) TremNie 223;

Nieskończoną wdzięczność wyrażam JW Panu za pozwolenie mi dwóch tomów Jeografii do czytania (Alojzy Osiński do Hugona Kołłątaja, 1806) KołCzac 119

Z wdzięcznością przyjęłam dar mi od niej ofiarowany (kasztelanowa do znajomej, 1819) HoffPam1, 64;

Tym większą czuję wdzięczność dla Pana, im mniej zarobiłem na łaskę (Franciszek Karpiński do wydawcy, 1820) KarpKor 227;

Nie ma słów na wyrażenie mojej wdzięczności i gdybym się o to kusił, miałbym się za niewdzięcznego (oficjalista do chlebodawcy, 1821) ChrzPam 180;

Serce moje tak wezbrało wdzięcznością, że nie jestem ani w stanie, ani w chęci zatrzymać jej potoku (Seweryn Goszczyński do przyjaciela, 1838) GoszLis 32;

Oświadczenie Pańskie wspierania mnie [...] przyjmuję z wielką wdzięcznością (literat do kolegi, 1842) KorGrab1, 55.

W ekscerpowanej korespondencji nie odnajdujemy natomiast fraz jestem obligowany/zobowiqzany - być może były właściwe raczej dla kontaktów bezpośrednich. Jedyny raz spotykamy taką formułę, dodatkowo nietypowo przekształconą, w liście rektora Akademii Krakowskiej do Ignacego Potockiego z 1790 roku:

Za powinszowanie pierwszeństwa [...] łaskawie mi oświadczone, przy złożeniu najpokorniejszego dziękczynienia znam się być obowiqzanym do nieustannej wdzięczności KorPot 210.

Wydaje się, że w listach chętniej niż w konwersacjach stosowano omawiany tu typ podziękowań. Forma pisana najwyraźniej bardziej sprzyjała używaniu rozbudowanych formuł i zasługi odbiorcy nie musiały być aż tak duże jak w przypadku kontaktu bezpośredniego. Sam człon werbalny nie wskazywał na miejsce w hierarchii społecznej adresata. Takie podziękowania kierowano zarówno do osób o podobnej randze pragmatycznej, jak i do tych o niższym lub wyższym statusie od nadawcy. 


\section{7. „BÓG ZAPŁAĆ” I PRZEKSZTAŁCENIA}

\subsubsection{W rozmowach}

Formuła Bóg zapłać należy do najstarszych polskich aktów podziękowań. Jeszcze w dobie średniopolskiej była powszechnie stosowana ${ }^{10}$, natomiast w badanym okresie wyraźnie traci na popularności na rzecz dziękuję. Używano jej głównie w niższych warstwach społecznych: wśród chłopów, mieszczan i drobnej szlachty. W ten sposób zwracano się również do duchownych.

Najczęściej była stosowana w relacjach symetrycznych:

Bóg zapłać za odwiedziny (szlachcic do gościa, II poł. XVIII w.) WójDw 107;

Bóg ci zapłać (kwestarz do szlachcica, II poł. XVIII w.) ChodźPam 92;

Bóg zapłać Jegomościu dobrodziejowi, żeś do mnie zawitał (łowczy do kwestarza, II poł. XVIII w.) ChodźPam 95;

Bógże ci zapłać (chłopka do Cyganki, II poł. XVIII w.) KniaźDram 142;

Kumie! O, Bóg wam zapłać (górale, I poł. XIX w.) KorzDram 185;

Bóg wam zapłać, pani kumo (chłop do swatki, I poł. XIX w.) HoffOpis 176;

Bóg ci zapłać łaski tyle (szlachcic do przyjaciela, I poł. XIX w.) FrDz2, 142;

Bóg zapłać, Bóg zapłać za dobre życzenia (szlachcianka do przyjaciółki, lata 40. XIX w.) PrusMor 104;

Bóg zapłać Naściu (chłop do znajomej, poł. XIX w.) KraszJary 180;

Bóg ci zapłać, Chwedku (chłopi, poł. XIX w.) KraszJer 129.

Akt ten mógł być także przejawem językowego dostosowania się do odbiorcy. Działo się tak w sytuacji, gdy osoba posiadająca wyższy status społeczny, zwracała się do kogoś pochodzącego ze środowiska, gdzie takie podziękowanie było powszechnie przyjęte:

Bóg ci zapłać, moja Wygodnisiu (szlachcic do lichwiarki, II poł. XVIII w.) CzarKom 176;

Bóg wam zapłać, Macieju (pan do chłopa, II poł. XVIII w.) WybDr 253;

Bóg ci zapłać ojcze Kleofasie, że mi ciężar z głowy zdjąłeś (generał do zakonnika, II poł. XVIII w.) RzewLis1, 222;

Kochany Panie Macieju, Bóg ci zapłać (baron do szlachcica zaściankowego, poł. XIX w.) ŁozCh1, 74.

Osoby o niższym statusie również dziękowały w ten sposób swoim wyżej postawionym dobroczyńcom:

Bóg ci zapłać, paniczku (Cyganka do szlachcica, I poł. XIX w.) SkarbDod 101;

Bóg zapłać (chłop do lekarza, poł. XIX w.) KraszJary 35;

Za dobre serce - Bóg zapłać (plenipotent do hrabiego, poł. XIX w.) KraszH 69.

Czasem podziękowanie to nabierało ironicznego wydźwięku:

${ }^{10}$ Ibidem, s. 190. 
Bóg zapłać waszmość panu za tak zbawienne nauki (szlachcic do znajomego, II poł. XVIII w.) BohK1, 329;

Ach, Bóg ci zapłać, mości panie guwerner, za tak piękną edukacją (szlachcic do guwernera syna, który nauczył swego podopiecznego hazardu, II poł. XVIII w.) BohK1, 120;

Bóg zapłać za łaskawą przestrogę, całuję nóżki asindzieja i wynoś mi się, pókiś cały (plenipotent do pisarza, poł. XIX w.) KraszH 38.

Podziękowanie to nie miało dużej mocy illokucyjnej. Rzadko było amplifikowane. Zwykle obudowa etykietalna tego aktu sprowadzała się do adresatywu celownikowego wstawianego pomiędzy dwa składniki frazy lub wołaczowego, który zamykał formułę.

Inny, bardziej uroczysty wariant tej formuły zawierał rozkaźnik wyrażany opisowo:

Niech ci Bóg zapłaci (teść do zięcia, pocz. XIX w.) WójN 244;

Niech ci Bóg płaci (kapitan do proboszcza, pocz. XIX w.) WójN 28; (chłop do syna, poł. XIX w.) KraszJer 163;

Niech Bóg zapłaci za dobre serce (plenipotent do Żyda, poł. XIX w.) KraszH 99. wić:

Czasownik zapłacić bywał zastępowany nadgrodzić/nagrodzić/błogosła-

Niech ci to Bóg nadgrodzi (plenipotent do szlachcica, II poł. XVIII w.) WybDr 209;

Bóg niechaj za to nadgrodzi (chłopi, II poł. XVIII w.) KniaźDram 175;

Bóg najwyższy niech wam i waszym potomkom tę przyjaźń waszą dla mnie wynadgradza (Tadeusz Kościuszko do adiutantów, 1793) PamGąs 107;

Niechże ci Bóg nagrodzi (córka kapitana do barona, I poł. XIX w.) FrDz2, 321;

Dziękujemy pani, niech panią Pan Bóg błogosławi (chłop do szlachcianki, I poł. XIX w.) KorzOk 6;

Niech was Bóg błogosławi i nagrodzi (starzec do chłopa, lata 20. XIX w.) OlPam1, 130;

Niech wam Bóg błogosławi, złote, serdeczne panienki, niech wam wszystko dobre zsyła (chłopka do guwernantki i szlachcianki, poł. XIX w.) DmNa 124;

O, niech ci Bóg nagrodzi (mieszczki, lata 60. XIX w.) KraszSt 81.

Nieco makabrycznej formuły opartej na tym szablonie mieli też używać między sobą powstańcy styczniowi. Podziękowanie to przypominało czym groził udział w powstaniu:

Niech ci to Bóg szubienicą wynagrodzi KuKas 302.

W ekscerpowanych tekstach kilkakrotnie w funkcji podziękowania pojawiają się także formuły z członem werbalnym daj Boże:

A dajże ci Boże zdrowie panie Romanie (szlachcic do hrabiego, przełom XVIII/XIX w.) BykPam2, 73;

Daj Panie Boże odsłużyć (chłop do swatki, I poł. XIX w.) HoffOpis 177; 
Bodajże ci Bóg dat zdrowie (lichwiarz do szlachcica, I poł. XIX w.) FrDz1, 200;

Daj Boże zawdzięczyć ci twoje dobre serce (lekarz do chłopki, poł. XIX w.) KraszJary 17.

\subsubsection{W listach}

W korespondencji badanego okresu formuły podziękowań o religijnym charakterze są bardzo rzadkie. Wszystkie odnotowane użycia pochodzą dopiero z XIX wieku, a odbiorcami takich aktów są przyjaciele:

Niechaj Bóg Najwyższy nagrodzi wam, że się zajmiecie uczniami moimi (Ignacy Domeyko do przyjaciół, I poł. XIX w.) DomL 34;

Niech Bóg nagrodzi wam za tak wielką pociechę uczynioną dla mnie (Ignacy Domeyko do przyjaciól, I poł. XIX w.) DomL 48;

Niech to Wam Pan Bóg zapłaci (lekarz do przyjaciół, 1842) MorLis 70;

Niech ci Bóg nagrodzi twoją dla mnie przyjaźń (Teofil Lenartowicz do przyjaciela, 1850) LisLen 8;

Niech Wam Bóg zapłaci za powieść pt. „Mogiły”, którą z rozrzewnienie przeczytałem (Teofil Lenartowicz do Józefa Kraszewskiego, 1858) LenarKor 25;

Niech Ci Bóg spokojem ducha i wszelkim błogosławieństwem zapłaci za tę wielką radość i pociechę jaką mi sprawił Twój list z Rzymu (Józef Kraszewski do Teofila Lenartowicza, 1858) LenarKor 26.

\section{8. „UPADAM DO NÓG”, „CAŁUJĘ RĄCZKI” ITP.}

Badany materiał pozwala wnioskować, że formuły nazywające gesty typu całuję raczki, upadam do nóg itp. były wykorzystywane nie tylko jako akty powitań i pożegnań, ale niekiedy również w funkcji podziękowań. W dialogach takie frazy są rzadkie:

Upadamy do nóg waszmość pana dobrodzieja (narzeczeni dziękując ojcu panny za zgodę na ślub, II poł. XVIII w.) BohK2, 154;

Upadam do nóg. Bardzo dziękuję. (szlachcic dziękując gospodarzowi za poczęstunek, pocz. XIX w.) PamFel1, 316 - w tym wypadku dla wzmocnienia efektu dodane zostało także podziękowanie bezpośrednie.

Charakterystyczne dla konwersacji były formuły tworzone wedle szablonu niech $(\dot{z} e)+1$. osoba czasownika oznaczającego gest:

A, niechże cię uściskam za takie nauki (szlachta, I poł. XIX w.) FrDz1, 163;

Panie Auguście, niech cię uściskam (szlachta, lata 40. XIX w.) RusWar2, 66.

Zdarzają się też zupełnie niestandardowe frazy:

A pani daj mi jeszcze swą uścisnać rączkę i podziękować (starszy szlachcic do młodej dziewczyny, I poł. XIX w.) KorzKom 324. 
Nieco częściej formuły odwołujące się do gestów spotykamy w ówczesnej korespondencji. Większość odnotowanych użyć pochodzi z osiemnastego wieku. Od aktów powitań i pożegnań różnią się przede wszystkim tym, że zawierają objaśnienia powodów podziękowań. W zebranym materiale rolę członu werbalnego pełni najczęściej czasownik całować:

Za uczynioną nadzieję mówienia z Księciem Imci Replinem (sic!) o szkody poczynione tak mnie jako i moim dworskim serdecznie nóźki całuję (kasztelanowa do brata, 1764) LiKos 74;

Całuję Cię $w$ buzię za przysłane papiery (Jan Śniadecki do podwładnego, 1792) ŚniaLis 46;

Całuje tysiąc razy łaskawe Jej za nią [pociechę] raczki (arystokrata do starościny, 1792) SzymLis 25;

Catuję ręce za doniesienie o szczęśliwości sanculotów w Holandyi (sekretarz do Ignacego Potockiego, 1793) TKor 157;

Catuje nogi za daną wiadomość o cnotliwym [...] Kościuszce (sekretarz do Ignacego Potockiego, 1793) TKor 124;

Za brzoskwinie calujemy raczki (arystokrata do starościny, 1795) SzymLis 86;

Całuje Jej raczki za łaskawe wyrazy (arystokrata do starościny, 1796) SzymLis 95;

Za pulares, który Babunia szyje dla mnie, raczki Jej całuję (Józef Kraszewski, 1839) KraszLis 92;

Całuję raczki Drogiej Mamy i nózki Mamy za nasiona, z których Zosia będzie bardzo rada (Józef Kraszewski, 1844) KraszLis 120.

Pozostałe odnotowane formuly:

Za doniesienie nowin o Litwie $z$ upadnieniem do nóg WKMci dziękuję (Ksawery Branicki do Stanisława Augusta Poniatowskiego, 1768) KonfB 146;

Teraz mię ścielę u nóg Najłaskawszego Monarchy dziękując wiadomym i znajomym sercem za obdarzenie mię charakterem ręki Pańskiej (Adam Naruszewicz do Stanisława Augusta Poniatowskiego, 1775) KorNar 45;

Za wyrazy łaskawe składam mnie u nóg Pańskich (sekretarz do Ignacego Potockiego, 1792) TKor 99.

\section{9. „JAKŻE MAM DZIĘKOWAĆ...?”}

Na koniec warto wspomnieć o jeszcze jednym specyficznym sposobie wyrażania podziękowań, który obserwujemy w badanym materiale. Są to akty, w których nadawca mówił o swojej rzekomej bezradność wobec ogromu dobroci, której doznał ze strony adresata - zamiast tworzenia ceremonialnych przeprosin stwierdzał, że żadne nie będą wystarczające. Akty te są mocno zindywidualizowane. Często miały postać pytania kierowanego do odbiorcy, szczególnie w przypadku kontaktu ustnego: 
Jakże ci podziękować potrafię, żeś się została? (wuj do siostrzenicy, II poł. XVIII w.) CzarKom 355;

Obsypałeś mnie pan dobrodziejstwami, jak ci się potrafię odwdzięczyć? (aktorka do szlachcica, kon. XVIII w.) PamOch2, 87;

A mój łaskawco! jakże ci za taką dobroć mam dziękować? (szlachta, lata 40. XIX w.) OsP1, 101.

Użycie takiego retorycznego pytania możliwe było też w liście:

Jakże mam dziękować za pamięć o moim „Kwestarzu”? Wyrazić nie zdołam! (Adam Pług do Pauliny Wilkońskiej, 1852) WilkWsp 282.

Zwykle jednak w przypadku epistolografii są to zdania oznajmujące:

Trudno mi dostatecznie podziękować za tak pożądane wiadomości (Adam Mickiewicz do przyjaciela, 1831) KorMic 49;

Podziękować Ci nie mogę dosyć za Twą przyjacielską prawdziwą pomoc (Fryderyk Chopin do przyjaciela, 1839) ChopKor1, 346;

Nie mogę dosyć wyrazić mojej wdzięczności za Jego nieoszacowane listowanie ze mną (literat do kolegi, 1842) KorGrab2, 81;

Nie ma Ci się czym odwdzięczyć prócz serdecznych, ale czczych podziękowań (Józef Kraszewski do brata, 1845) KraszLis 128;

Nie mam już słów w istocie, aby godnie podziękować za niego (Wincenty Pol do księżnej, 1845) LisPol 143.

\subsection{UWAGI KOŃCOWE}

Nowopolskie akty podziękowań są mocno zróżnicowane. $Z$ jednej strony obserwujemy tendencję do uproszczeń formalnych - frazy typu sktadam dzięki chętnie skracano do dzięki, a dominującym sposobem językowego okazywania wdzięczności w kontaktach ustnych jest prosta formuła $\mathrm{z}$ czasownikiem performatywnym - dziękuję. Z drugiej jednak strony popularność zdobywają także konstrukcje analityczne w rodzaju jestem wdzięczny/obowiqzany, choć $\mathrm{i}$ tutaj widoczne jest dążenie do uproszczeń, bo w rozmowach człon werbalny często był skracany. Używanie powszechnej w okresie średniopolskim frazy Bóg zaptać staje się coraz częściej wyznacznikiem przynależności do niższych warstw społecznych.

W epistolografii chętniej stosowano rozbudowane formuły, jednak rzadko długość aktu wskazywała na status nadawcy i adresata listu. O postaci podziękowań decydowały raczej takie czynniki sytuacyjne jak wielkość zasługi odbiorcy oraz stopień oficjalności korespondencji. Wiele formuł mających wcześniej dużą wartość honoryfikatywną uległo konwencjonalizacji.

Wariantywność formalna podziękowań zarówno ustnych, jak i epistolarnych jest duża - szablonowe akty etykiety chętnie modyfikowano, jednak w większości wypadków stosunkowo łatwo wskazać na mechanizmy tych przekształceń. 


\section{POWINSZOWANIA (GRATULACJE)}

Ten akt mowy służy wyrażeniu pozytywnego stosunku nadawcy do działań odbiorcy ${ }^{1}$. Już w dobie staropolskiej zaczęto odróżniać gratulacje od życzeń ${ }^{2}$. Rozgraniczenie to opierało się na zasadzie, że gratulacje dotyczą faktów, które już miały miejsce, a życzenia są projekcją przyszłych, pozytywnych dla adresata zdarzeń. W badanym okresie podstawowym wykładnikiem gratulacji był czasownik winszować $c^{3}$, który czasami występował również w życzeniach - początkowo życzyć i winszować traktowano synonimicznie ${ }^{4}$. W ekscerpowanych tekstach w ogóle nie pojawia się powszechnie dziś używany czasownik performatywny gratuluje.

Akt powinszowań występował zwykle w początkowej fazie rozmowy:

Pana dobrodzieja witam i winszuję aplauzów (szlachta, II poł. XVIII w.) KK 95;

Najczęstszą reakcją na gratulacje było podziękowanie:

- Winszuje, winszuje, panie Grzegorzu!

- A tak, dziękuję ci. (huzarzy, I poł. XIX w.) FrDz1, 301.

\section{1. „WINSZUJĘ” I PRZEKSZTAŁCENIA}

\subsubsection{W rozmowach}

Formuła ta miała szeroki zasięg społeczny $-\mathrm{z}$ analizowanych tekstów wynika, że używał jej zarówno król, jak i sługa. Winszuję łączyło się przede wszystkim z celownikowymi adresatywami, rzadziej pojawiają się także wołaczowe. Często wykorzystywanym sposobem na zwiększenie grzeczności formuły było dodanie do czasownika konwencjonalnych okolicznikowych określeń: serdecznie, mocno, z catego serca.

W przypadku relacji symetrycznej budowa poszczególnych aktów jest mocno zróżnicowana. Spotykamy zarówno formuły krótkie, składające się tylko z performatywu i form adresatywnych, jak i bardziej rozbudowane, zawierające dopełnienie lub dopełnieniowe zdanie podrzędne:

${ }^{1}$ M. Marcjanik, Polskie czasowniki adresatywne. Pragmatyka, semantyka, sktadnia, Kielce 1987, s.100-101.

${ }_{2}^{2}$ M. Cybulski, Obyczaje językowe dawnych Polaków. Formuły werbalne w dobie średniopolskiej, Łódź 2003, s. 211.

${ }^{3}$ Leksem ten jest zapożyczeniem niemieckiego wünschen.

${ }^{4}$ Również dziś akty te są sobie bliskie i zdarza się, że stosujemy je łącznie. M. Marcjanik, Polska grzeczność językowa, Kielce 2000, s. 73. 
A, to piękne starostwo, winszuję waszmość panu serdecznie (szlachta, II poł. XVIII w.) BohK2, 382;

Winszujemy ci, pani (szlachta, I poł. XIX w.) KorzKom 353;

A! to ci winszuje (doktor do aptekarza, poł. XIX w.) KraszDz 137;

A, winszuję z całego serca (szlachta, poł. XIX w.) BujSt 288;

Winszuje waćpanu tego stopnia (stolnik do majora, poł. XVIII w.) RzewMich 95;

Winszuje waćpannie, że to czytać możesz (szlachcic do szlachcianki, II poł. XVIII w.) CzarKom 332;

Winszuję tego szczęścia (podstolina do zalotnika, lata 80. XVIII w.) ZabF 45;

Winszuje ci tych ran (kanonik do szlachcica, kon. XVIII w.) PamGąs 23;

A tobie z serca winszuję, żeś doczekał rozporządzić losem pierwszego dziecka (szlachta, pocz. XIX w.) KuKas 173.

Przykłady użyć w relacji asymetrycznej, gdy osoba posiadająca wyższy status społeczny zwracała się do niżej postawionej:

Winszuję tobie rabinie, że jesteś duchownym tego cnotliwego ludu, wam, że macie mądrego waszego rabina (król Stanisław August Poniatowski do Żydów, II poł. XVIII w.) PamRadz 58 - oficjalna sytuacja sprawiła, że formuła jest mocno rozbudowana;

Winszuję ci, moja Felisiu (szlachcianka do służącej, II poł. XVIII w.) CzarKom 301 - wykładnikiem niższości odbiorcy jest tu poufała forma adresatywna;

Winszujemy i cieszymy się z serca (pułkownik do podchorążyny, I poł. XIX w.) KorzKom 112 - formuła została rozszerzona o wyrazy radości.

Akt ten był również używany przez osoby o niższej randze do wyżej postawionych:

Tego kawalera mocno waszmość pannie winszuje (pokojówka do szlachcianki, II poł. XVIII w.) BohK2, 14;

Winszuję waszmość panu tak znacznego zwycięstwa (sługa do szlachcica po pojedynku, II poł. XVIII w.) BohK1, 354;

Winszujemy, winszujemy jaśnie wielmożnemu panu (Żydzi do szlachcica, I poł. XIX w.) KorzOk 71;

Winszuje panu i tej pani, którą protegujesz, nadzwyczajnego szczęścia (adwokat do szlachcica, lata 20. XIX w.) SkarbSt 88.

Jedynie raz w badanych tekstach odnotowujemy analityczny wariant formuly $\mathrm{z}$ accusativem nazwy czynności powinszowanie:

Doczekałem się dnia, tyle pożądanego od nas sług i przyjaciół waszej książęcej mości, w którym mogę mu złożyć najgłębsze powinszowanie, najprzychylniejsze życzenia (szlachcic do księcia, II poł. XVIII w.) RzewLis1, 133 - akt ten łączy gratulacje z życzeniami. Taka bardzo ceremonialna, amplifikowana przymiotnikami w superlatywie formuła jest zapewne wynikiem dużej różnicy rang między partnerami interakcji.

Nieco częściej pojawiają się gratulacje, które zamiast czasownika performatywnego zawierają orzeczenie modalne: 
Winszować waszmość panu trzeba, żeś tak łaskawym okiem na wszystko patrzał (szlachcianka do szlachcica, II poł. XVIII w.) CzarKom 345;

Prawdziwie można powinszować wam panie Jerzy tak szlachetnego syna (hrabia do szlachcica, przeł. XVIII/XIX w.) BykPam2, 76;

Chciałem jak mi powinność każe, powinszować jasnej... to jest łaskawej pani (ekonom do szlachcianki, I poł. XIX w.) KorzOk 21;

Powinszować trzeba pani dobrodzice tak pięknej córki (szlachcic do szlachcianki, poł. XIX w.) DmNa 36.

W badanych tekstach możemy też znaleźć powinszowania, które trudno uznać za akty etykiety językowej, bo nie wyrażały radości z osiagnięć odbiorcy, ale służyły do okazywania dezaprobaty wobec jego zachowania - miały wydźwięk ironiczny:

Winszuję tego szczęścia (podstolina do zalotnika, który chwali się swoim powodzeniem u kobiet w stolicy, II poł. XVIII w.) ZabF 45;

Winszuję waćpannie, że to czytać możesz, bo się domyślam, że to musi być arcyniezabawne (szlachcic z ironią do panny, II poł. XVIII w.) CzarKom 332;

Winszować waszmość panu trzeba, żeś tak łaskawym okiem na wszystko patrzał (szlachcianka ironicznie do szlachcica, II poł. XVIII w.) CzarKom 345;

To widzę, ojciec Kleofas w sny wierzy i używa brewiarza do badania przyszłości, winszuję, ale nie zazdroszczę (ksiądz do mnicha, II poł. XVIII w.) RzewLis2, 44;

Tego kawalera mocno waszmość pannie winszuję (pokojówka $\mathrm{z}$ ironią do panny, II poł. XVIII w.) BohK2, 14;

Prawdopodobnie moda na takie sarkastyczne gratulacje przeminęła wraz z XVIII wiekiem, bo w późniejszych tekstach ich nie znajdujemy.

\subsubsection{W listach}

Formuły te są zbliżone do ustnych, nieco częściej pojawia się szyk przestawny - dopełnienie poprzedza czasownik performatywny. W badanej korespondencji dominują gratulacje składane adresatom o randze pragmatycznej równej nadawcy:

Winszuję operetty włoskiej (Ignacy Krasicki do przyjaciela, 1765) KKor1, 118;

Zakończenia winszuje roku przeszłego (kasztelanowa do znajomej, 1770) LisKos 94;

Prawdziwie winszuje JW Pani Dobrodziejce tej odwagi (kasztelanowa do znajomej, 1771) LisKos 127;

Winszuje serdecznie synowca (Grzegorz Piramowicz do Ignacego Potockiego, 1777) KorPot 21;

Doktora Węgrzyna winszuję (Ignacy Krasicki do brata, 1781) KKor2, 15; 
Narodzonego syna Leona winszuje (Ignacy Krasicki, 1781) KKor2 45;

Winszuję tobie z duszy ukończenia nauk w szkole handlowej (Ignacy Domeyko do przyjaciela, I poł. XIX w.) DomL 33;

Winszuje WPanu, że mając tak światłego pomocnika [...] uzyskasz zapewne najlepsze dzieło (Hugo Kołłątaj do współpracownika, 1806) KołCzac 85;

Winszuje J. W. Panu tak znakomitego daru Monarchy dla Gimnazjum wołyńskiego (Hugo Kołłątaj do Tadeusza Czackiego, 1806) KołCzac 279;

Winszuje pannie Sabinie zmienionego szczęśliwie stanu (Juliusz Słowacki w liście do matki, 1832) KorSł 106;

Bardzo winszuję, że Pan masz stosunki z takiemi mężami (literat do literata, 1842) KorGrab 55;

Winszuję ci go właśnie (lekarz do przyjaciela, 1849) MorLis 132.

W przypadku wyższej rangi nadawcy formuły wyglądają podobnie:

Winszuję ci z duszy szczęśliwego początku (król Stanisław August Poniatowski do Ksawerego Branickiego, 1768) KonfB 19;

Winszuje JW Panu żeś pozyskał w Wiedniu wrócenie gabeły (kasztelanowa w liście do siostrzeńca, 1781) LisKos 163;

Postępu pęzla Twojego winszuję ci (ojciec do Józefa Ignacego Kraszewskiego, 1858) KraszLis 293.

\subsection{UWAGI KOŃCOWE}

Przedstawione akty gratulacyjne są mało urozmaicone pod względem językowym - większość powiela ten sam typ formalny zarówno w komunikacji ustnej, jak i pisemnej. Pod względem stylistycznym prezentują nieco większą różnorodność oraz swobodę. Tylko pojedyncze użycia pokazują łączenie aktu powinszowań z wyrazami radości i życzeniami. 


\section{9. ŻYCZENIA}

Życzenia należą do niebezwzględnie obowiązkowych zachowań grzecznościowych - odbiorca nie wymaga ich, a tylko oczekuje'. Składanie życzeń jest jednak przejawem respektowania jednej z ważnych zasad etykietalnych: dawania dowodów pamięci o partnerze ${ }^{2}$. Choć akty życzeń są realizowane ze względu na okazję ${ }^{3}$, to okoliczności ich wypowiadania są bardzo różne. Bodźcem do składania życzeń mogą być nie tylko imieniny, święta, rocznice, ale też wiele innych ważnych dla odbiorcy wydarzeń.

W badanym okresie te akty etykiety językowej powszechnie można znaleźć również w zakończeniach listów - zgodnie z ówczesną konwencją w subskrypcji wypadało adresatowi dobrze życzyć. Formuły takie zostały omówione w rozdziale poświęconym pożegnaniom (zob. 2.2.7.). Tutaj zostaną przedstawione jedynie akty, które znajdują się w innych niż finalna partiach listu i zwykle ich składanie wiąże się z jakąś okazją ${ }^{4}$.

\section{1. „ŻYCZĘ” I PRZEKSZTAŁCENIA}

W ekscerpowanej korespondencji człon werbalny najczęściej ma postać performatywu życzę. O ile w okresie średniopolskim niemal obowiązkowym elementem obudowy czasownika były konwencjonalne okoliczniki typu wiernie, uprzejmie, z serca, to w zebranym materiale życzę występuje najczęściej bez takich ozdobników:

Życze jako najpomyślniejszych do gustu i pożądania pomyślności (Ignacy Krasicki do brata z okazji imienin, 1760) KKor 40;

Życzę drogi szczęśliwej (Maria z Leszczyńskich do Adama Naruszewicza, 1762) KorNar 3;

${ }^{1}$ M. Marcjanik, Normy regulujace językowe zachowania grzecznościowe, „Przegląd Humanistyczny" 1990 , nr 7, s. 80.

${ }^{2}$ M. Marcjanik, Typologia polskich wyrażeń językowych o funkcji grzecznościowej, [w:] Język a kultura, t. 6, Polska etykieta językowa, red. J. Anusiewicz, M. Marcjanik, Warszawa 1992, s. 27.

${ }^{3}$ M. Marcjanik, Polska grzeczność językowa, Kielce 2000, s. 63.

${ }^{4} \mathrm{M}$. Cybulski pisze, że w okresie średniopolskim takie konwencjonalne życzenia umieszczano również w salutacjach; M. Cybulski, Obyczaje językowe dawnych Polaków. Formuly werbalne w dobie średniopolskiej, Łódź 2003, s. 203.

W dobie nowopolskiej zwyczaj ten najwyraźniej zanika - w inicjalnych partiach listu życzenia pojawiają się co prawda dość często, ale zwykle związane są z konkretną okazją. Umieszczanie ich na początku listu zgodne jest z grzecznościową zasadą polegającą na eksponowaniu osoby adresata. 
JMć Pani Hrabinie życzę sukcesu letkiego ${ }^{5}$ i zdrowia potem (Ignacy Krasicki do brata, 1763) KKor 71;

Jak najprędszej rekonwalescencyi et dinturnam incolumitatem intime [łac. i długiego zdrowia jak najserdeczniej] życzę (wojewoda wileński do kasztelana, 1763) PamKasz 126;

$\mathrm{Z}$ następującym rokiem życzę serdecznemu braciszkowi nowych pociech, szczęśliwości w najdłuższe, słabościami nieprzerwane, lata (siostra do Karola Radziwiłła, 1773) MorDiar 237;

Na początku Nowego Roku życzę Ci tych pomyślności, których zawsze (Jan Śniadecki do podwładnego, 1791) ŚniaLis 35;

Życzę Wam wszystkiego dobrego na ten Nowy Rok (Hugo Kołłąaj do ekonoma swoich dóbr, 1792) KołLis1, 155;

Życzę JWPanu szczęśliwego Nowego Roku, mój drogi baronie (hrabia, kon. XVIII w.) PamOśm5, 22;

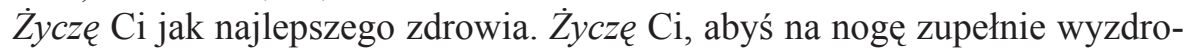
wiał (Fryderyk Chopin do przyjaciela, 1825) ChopKor1, 47;

Wszyscy życzymy Panu dobrego Nowego Roku, a sobie życzymy, aby Pan był dla nas w nowym roku takim, jakim był w starym (Salomea Słowacka do Antoniego Odyńca, 1826) LisRS 175;

$\dot{Z} y c z e ̨$ Panu, aby był dla niego rok ten jak najpomyślniejszy, jak najszczęśliwszy wpływ miał na całe jego życie (Salomea Słowacka do Antoniego Odyńca, 1826) LisRS 180;

Życzymy Panu Świąt wesołych, dobrych, miłych itd. itd. itd. (Salomea Słowacka do Antoniego Odyńca, 1827) LisRS 229;

Pani i Pannie Elsner rączki całuję i wszystkiego dobrego w Nowy Rok życzę (Fryderyk Chopin do Józefa Elsnera, 1831) ChopKor1, 207;

Życzę ci tu szczęścia, ciszy i spokojności (Juliusz Słowacki do matki, 1835) KorSł 260;

Życzę dosiego roku tobie i panu Wiktorowi (Narcyza Żmichowska do brata, 1838) ŻmLis 102;

Pojmuję, mój kochany, twoją radość i szczęście, dzielę je o tyle, o ile współczuciem przychylnego serca dzielić można, i życzę wam dwojgu, ażeby ta radość wasza zamieniła się wreszcie w pomyślność trwałą, długą jak życie (Seweryn Goszczyński do przyjaciela z okazji ślubu, 1841) GoszLis 122;

Życzę Wam dobrego roku i wszystkim znajomym (Fryderyk Chopin do rodziny, 1845) ChopKor2, 158;

Życzę Tobie, Bracie najmilszy wszelkiego dobra i błogosławieństwa dla prac Twoich Kapłańskich (zakonnik do współbrata, 1850) LisDuń 55;

Życzę Wam zdrowia i wszelkiej Łaski Bożej na ten rok nowy (zakonnik do współwyznawcy sekty Towiańskiego, 1853) LisDuń 216;

\footnotetext{
${ }^{5}$ Chodziło o poród.
} 
Życzę Ci świąt przyjemnych (Teofil Lenartowicz do przyjaciela z okazji Wielkanocy, 1854) LenLis 76.

Najczęstszym elementem obudowy takich aktów były celownikowe formy adresatywne. W przedstawionym materiale zwraca uwagę wysoka frekwencja życzeń noworocznych - wypadało je składać w ostatnim liście pisanym w starym roku lub w pierwszym roku nowego. W ówczesnych listownikach możemy znaleźć nawet wzory listów przeznaczonych specjalnie na tę okoliczność ${ }^{6}$.

Formuły zawierające okoliczniki są o wiele rzadsze. Najczęściej obserwujemy wyrażenie $z$ (całego) serca, które upowszechniło się już w XVII wieku ${ }^{7}$, inne przysłówki również mają konwencjonalny charakter:

Urodzenia jak najszczęśliwszego młodego infanta serdecznie życzę (Ignacy Krasicki do brata, 1767) KKor 159;

Z serca życzę abyś do zupełnego zdrowia jak najprędzej przyszedł (Stanisław August Poniatowski do Ksawerego Branickiego, 1768) KonfB 126;

Szczerze życzę, ażebyś Najlepszy z Królów, Panie i Dobrodzieju mój Jedyny, żył jak najdłużej, panował jak najszczęśliwiej, a prace, trudy i kłopoty swoje słodyczą dalszego życia nadgromadzone sowicie oglądał (Adam Naruszewicz do króla z okazji Wielkanocy, 1777) KorNar 67;

Cieszę się mocno, że już masz zajęcie i bardzo tobie życzę prędkiego awansu i sukcesu (Ignacy Domeyko do przyjaciela, I poł. XIX w.) DomL 36;

Życzę ci z całego serca ojcostwa jaknajprędszego i najpomyślniejszego (Seweryn Goszczyński do przyjaciela, 1842) GoszLis 138;

Z serca Ci życze polepszenie zdrowia (Zygmunt Krasiński do plenipotenta, 1858) KrasLis 314.

Możliwe były też życzenia z elipsą czasownika:

Szczęśliwych świąt Wojewodo (Zygmunt Krasiński z okazji Wielkanocy, 1843) KrasMał 30.

Formuły zawierające performatyw były kierowane zarówno do adresatów o statusie równym nadawcy, jak i do tych stojących wyżej lub niżej w hierarchii społecznej od piszącego. Czasem, gdy składano życzenia osobom posiadającym wysoką rangę pragmatyczna, stosowano formuły bardziej rozbudowane, w których wprowadzano honoryfikatywne konstrukcje analityczne i bogatą obudowę etykietalną:

Przyjać [...] raczysz sercem życzenia moje które są: aby JOWM Pan w zupełnej zdrowia czerstwości, pożądanych pełen sukcesów jak najpoźniejsze przepędził lata (Ignacy Krasicki do Jana Klemensa Branickiego, 1770) KKor1, 202;

${ }^{6}$ M. Korzeniowski, Pisarz listów powszechny: wybór wzorowych listów we szelkich stosunkach i okolicznościach potocznego życia: wzory przedstawień do władz rzqdowych, wekslów, obligów, kontraktów, cessyi, testamentów, rozmaitych zapisów, zaświadczeń, wszelkich aktów urzędowych i.t.p., Wrocław 1847, s. 34-37.

${ }^{7}$ M. Cybulski, Obyczaje językowe..., s. 205. 
Życzenia moje oświadczam [...] które z serca całego w potomne czasy wyrażam, przy pomyślnościach zupełnych i przy zdrowiu najczerstwiejszym (kasztelanowa do marszałka, 1790) LisKos 228;

Mam sobie za najświętszą powinność przesłać mu moje życzenia (oficjalista do chlebodawcy, 1827) ChrzPam 189.

W przypadku adresata o wysokiej randze życzenia mogły też zostać poprzedzone długim grzecznościowym wstępem, a zamiast performatywu używany był imiesłowowy równoważnik zdania:

Z okazji blisko następujących uroczystości Zmartwychwstania Pańskiego przyłączam WMPanu vota moje, życzqc Mu wszelkich pomyślności i zdrowia jako najczerstwszego w najdłuższe lata (Ignacy Krasicki do arystokraty, 1754) KKor 16;

Serdeczne tylko chęci moje składam wraz z sobą pod śliczne nogi WKs Mci Dobrki, życzac Jej jak najprędzszej Melioracyi (starosta do księżniczki, 1758) LM 118.

$\mathrm{W}$ osiemnastym wieku rozbudowane formuły pojawiają się tylko w relacjach asymetrycznych, natomiast w kolejnym stuleciu mniej ceremonialne konstrukcje analityczne spotykane są także w korespondencji osób o podobnym statusie społecznym:

Życzenia dobrych świąt składam (Salomea Słowacka do Antoniego Odyńca, 1827) LisRS 283;

Dziś Twoje imieniny, przesyłam Ci moje życzenia: niech Cię Bóg błogosławi w tym i przyszłym życiu (matka do Fryderyka Chopina, 1848) ChopKor2, 236;

Składajac przy nowym roku najszczersze życzenia wszelkiej pomyślności, dziękuję zarazem WPanu Dobrodziejowi za łaskawą pamięć (Tytus Chałubiński do wydawcy, 1848) ChałLis 35;

Na zbliżające się święto Wcielenia Słowa Bożego, Narodzenia Pańskiego, życzenia moje Wam niosę, abyśmy Słowo to w części nam naznaczonej, przyjęli, ożywili, ucieleśnili w sobie (zakonnik do przyjaciół, 1850) LisDuń 110;

Moje życzenia na Nowy Rok łaczę: aby zatryumfował Pan nasz Jezus Chrystus, aby prawo Jego zapanowało nad Narodami, aby Sprawa Boża zajaśniała (zakonnik do współwyznawców sekty Towiańskiego, 1850) LisDun 47.

W jeszcze innych wariantach wprowadzano tryb rozkazujący lub obudowywano akt życzeń prośbą:

Przyjm moje najszczersze życzenia na Święta i Nowy Rok dla siebie samego i Twojej rodziny (Zygmunt Krasiński do plenipotenta, 1853);

Przyjm więc od nas wszystkich najserdeczniejsze życzenia i bądź szczęśliwą (szlachcianka do przyjaciółki, lata 50. XIX w.) CieszT2, 249;

Prosze przyjać moje najszczersze życzenia na ten rok nowy (Zygmunt Krasiński do plenipotenta, 1856) KrasLis 121. 


\section{2. „WINSZUJĘ” I PRZEKSZTAŁCENIA}

Czasownik ten $\mathrm{w}$ znaczeniu życzyć występuje w badanym okresie rzadko raczej składano za jego pomocą gratulacje niż życzenia. Co ciekawe, niemal we wszystkich odnotowanych użyciach oprócz czasownika winszować dodatkowo pojawiają się formuły z życzyć. $Z$ analizowanego materiału wynika, że winszować oznaczało ogólnie akt składania życzeń - dopełnieniem mogły być tylko nazwy okazji. Inaczej niż w okresie średniopolskim, gdy winszuje funkcjonowało tak samo jak $\dot{z} y c z e$, w badanym okresie nie spotykamy formuł typu winszuje wszystkiego dobrego ${ }^{8}$. W celu określenia, czego konkretnie życzy się adresatowi, wprowadzano kolejny czasownik w postaci życzę:

Performatyw winszuje w ekscerpowanej korespondencji występuje jedynie wyjątkowo:

Świąt i kończącego się roku z gorliwem przywiązaniem winszuję JWMPPDD, życzyć nieustannie będę najwyższych pomyślności i najdostojniejszego z niemi stopnia (generał do hetmana, 1763) LisJal 69;

Winszuje wesołego alleluja i zdrowia dobrego życzę (Jan Śniadecki do podwładnego, 1792) ŚniaLis 44.

Pozostałe, występujące w zebranym materiale przypadki użycia winszować, to dość ceremonialne konstrukcje analityczne sygnalizujące zwykle wyższą rangę adresata:

Z powinnościami wrodzonego afektu listownie oświadczam J.O.W.Ks. Mci powinszowanie Świąt Zmartwychwstania Pańskiego, życzę z serca i proszę Boga, aby wlał na osobę W Ks. Mci wszelkie błogosławieństwa na tym świętym miejscu w każdy modlitwie pamięć moja nie ustaje (siostra do Karola Radziwiłła, 1774) MorDiar 238;

Przez brata mojego składam razem i powinszowanie szczęśliwego powrotu i życzenia przy zaczynającym się Nowym Roku (Ignacy Krasicki do króla, 1781) KKor2, 85;

Spieszę z powinszowaniem życzac zdrowia i najpomyślniejszych sukcesów (kasztelanowa do marszałka, 1788) LisKos 189;

Całej familij i Krzysi kochanej wyrażam powinszowanie Roku Nowego. Żyjcie mi JWW Panowie długo, bądźcie zdrowi, a czy będą pomyślności to lepiej tam wiecie niżeli ja, bo tu u nas nic nie słychać (kasztelanowa do marszałka, 1792) LisKos 269;

Nadchodzi Nowy Rok, trzeba by więc Ci powinszowanie, ale czegóż? wszystko masz, nic zatem Ci nie życzę prócz zdrowia, co teraz masz odzyskać (Fryderyk Chopin do przyjaciela, 1825) ChopKor1, 61;

${ }^{8}$ Ibidem, s. 207. 
Pozostaje mi tylko [...] nadchodzącego Roku Nowego Babuni Dobrodziejce powinszować i złożyć od nas wszystkich życzenia największych pomyślności, jakie się na ziemi spotykają (Józef Kraszewski do babki, 1841) KraszLis 103.

\subsection{FORMY IMPERATYWNE}

W początkach doby nowopolskiej w funkcji życzeń rozpowszechnione były formy trybu rozkazującego. Większość z nich miała charakter religijny, co jest w pewnej mierze kontynuacją stanu średniopolskiego, gdy życzenia często miały postać fraz typu Boże daj, Bóg pomóż ${ }^{9}$ W ekscerpowanej korespondencji taką formułę odnotowano jedynie raz w życzeniach imieninowych z 1782 roku, które Ignacy Krasicki składał bratu:

Daj Boże jak najdłuższe lata pomyślności, zdrowia, a co nade wszystko, wewnętrznej spokojności i ukontentowania KKor2, 132.

W pozostałych wypadkach życzenia o genezie religijnej mają postać analitycznych form rozkaźnika, przez co zwiększa się ich grzeczność, ale też często stają się nieco patetyczne:

Niech Bóg wspiera Jego zamysły i przedsięwzięcia, zdrowia i pomyślności $u \dot{z} y c z a$ (sekretarz do Ignacego Potockiego z okazji nowego roku, 1792) TKor 117;

Niech Bóg $d a$, żeby nowy zaczynający się rok był JW Panu Dobrodz. początkiem długich i szczęśliwych wypadków, tak osobie Jego jako i Ojczyźnie (Hugo Kołłątaj do księdza, 1793) KołLis1, 158;

Niech ci Bóg we wszystkim szczęści i błogosławi (Jan Śniadecki do przyjaciela, 1819) ŚniaLis 197;

Niech cię Bóg wszechmocny strzeże, ochroni od wszelkiego zła (Zygmunt Krasiński do przyjaciela, 1835) KrasJary 13;

Niech cię Opatrzność Boska strzeże i niech rosnq w tobie kwiaty, by później owoce z nich dojrzały (Zygmunt Krasiński do przyjaciela, 1838) KrasPot 55;

Niech cię anioły strzega, Erazmie kochany, niech cię duchy niebios pilnują (Narcyza Żmichowska do brata, 1838) ŻmLis1, 74;

Niech ci Bóg zdarzy żonę, która odbije duszę twoją, jak czyste zwierciadło (Zygmunt Krasiński do przyjaciela, 1839) KrasJar 23;

Niech Ci Bóg da to wszystko, czego tylko zapragnąć możesz, a nam dozwoli widzieć się z Tobą (Fryderyk Chopin do siostry, 1841) ChopKor2, 51;

Niech ci Bóg dopomoże przygotować się i spełnić tę czynność z pożytkiem dla Sprawy (Seweryn Goszczyński do znajomego z kręgu Towiańskiego, 1843) GoszLis 163;

Niech Bóg miłosierny wspomaga Ciebie łaską swoją (zakonnik do współbrata, 1849) LisDuń 28;

${ }^{9}$ Ibidem, s. 209-210. 
Niech tam Bóg zsyła z Nowym Rokiem na Kochaną Mamę wszystkie swoje błogosławieństwa i dobrodziejstwa, jakich my Jej z serca dziecięcego życzemy zawsze (Józef Kraszewski do matki, 1852) KraszLis 231.

Większość prezentowanych powyżej życzeń pochodzi z XIX wieku i to prawdopodobnie wtedy upowszechniają się tego typu akty.

Formuły imperatywne występowały nie tylko w życzeniach o charakterze religijnym. W taki sam sposób życzono sobie zdrowia, szczęścia itp. Formy syntetyczne:

Bqqdź mi zdrowa, kochana Bogini, miej w pamięci i w sercu przywiązanego i dozgonnego podnóżka Twego (starosta do księżniczki, 1758) LM 121;

$\dot{Z} y j$ JW. Pani Dobrodziejko długo i zdrowo (kasztelanowa do znajomej z okazji imienin, 1771) LisKos 138;

Żyj więc szczęśliwy, drogi, luby Jasiu (Fryderyk Chopin dla przyjaciela z okazji imienin, 1826) ChopKor1, 68;

Badźcie zdrowi, szczęśliwi (Salomea Słowacka do chrześniaka, 1850) LisRS 323.

\subsubsection{Formuly z opisową formą trybu rozkazującego}

Niech rok nowy najpomyślniejszemi sukcesami wyniesie JWMP Dobr. au plus haut point de gloire [franc. „najwyższy stopień chwały] (generał do hetmana, 1764) LisJak 70;

Niech on [nowy rok] będzie dla ciebie szczęśliwym i spokojnym (Zygmunt Krasiński do przyjaciela, 1840) KrasPot 77;

Niech ci się szczęści w życiu, niech wszystko dobre i piękne spada na ciebie (Zygmunt Krasiński do przyjaciela, 1840) KrasPot 97;

Przede wszystkim dług nowego roku, niech więc z pierwszemi dniami jego urwa się wszystkie przeciwności twojego życia, a ciagnq się same powodzenia, urok młodzieńczego wieku, rozkosze poetyckiego świata, poczciwa sława, skromny dostatek it.p. (Seweryn Goszczyński do Bohdana Zaleskiego, 1841) GoszLis 116 ;

Niech się Wam chowa [syn] w nadziejach naszych na pociechę krajowi i niech będzie Tobie podobien, tego życzę z serca i jemu i Tobie (Wincenty Pol do przyjaciela, 1842) LisPol 99;

A gdy o roku mowa, niechże z serca zleję najszczersze życzenia moje dla Papy (Józef Kraszewski, 1843) KraszLis 110. 


\subsection{UWAGI KOŃCOWE}

W porównaniu z okresem średniopolskim repertuar szablonowych aktów etykiety, za pomocą których składano życzenia, nieco się zmniejszył. Wyszły z użycia formuły typu proszę Pana Boga, aby; sprzyjam ci sukcesów ${ }^{10}$. Syntetyczna postać rozkaźnika coraz częściej jest wypierana przez uroczystsze formy analityczne.

Choć postać formalna ówczesnych życzeń jest mało urozmaicona, to pod względem leksykalnym są one często bardzo oryginalne - nie ograniczano się do standardowych dziś dopełnień typu zdrowia, szczęścia, wszystkiego najlepszego. Szczególnie ludzie pióra chętnie tworzyli niepowtarzalne życzenia, które zawsze miały większą wartość honoryfikatywną od tych szablonowych.

10 Ibidem, s. 211. 


\section{TOASTY}

W ramach wypowiedzi pełniących funkcje toastów należy wydzielić dwa ich rodzaje: toasty-przemówienia oraz toasty-zachęty do picia $^{1}$. Przedmiotem analizy jest tu wyłącznie typ drugi ${ }^{2}$, będący najczęściej po prostu odmianą życzeń, których moc ma wzmacniać rytuał wypicia alkoholu³. Świadczy o tym chociażby taka forma toastu:

Dobrego zdrowia wam (chłopi w karczmie, lata 40. XIX w.) KraszU 75 możliwa jest tu interpolacja czasownika życzyć.

\subsection{FORMUŁY ZAWIERAJĄCE CZASOWNIK W 1. OSOBIE I PRZEKSZTAŁCENIA}

Pierwotnie formuły toastów-zachęt do picia składały się z dwóch członów jeden kierowano do adresata, podając mu naczynie z alkoholem, a drugi odnosił się do osoby trzeciej (obecnej lub nie) np. piję do waszmości za zdrowie jegomościt. Ewolucja formuł toastów polegała przede wszystkim na pomijaniu jednego członu - proces ten możemy obserwować już w okresie średniopolskim. W ekscerpowanych tekstach ani razu nie odnotowano toastu w pierwotnej, dwuczłonowej postaci.

1. Redukcja członu pierwszego mogła być tylko częściowa i polegać na opuszczeniu dopełnienia (np. do ciebie). Jądrem formuły był najczęściej czasownik pić w czasie teraźniejszym lub przyszłym - jedynie raz w zebranym materiale zastępuje go wznoszę. Pito przede wszystkim $(z a)$ zdrowie, co zapewne wiązało się z ówczesnym przekonaniem o leczniczych właściwościach alkoholus:

Pije zdrowie mego zacnego przyjaciela pana Kacpra Płazy, pierwszego rębacza na kuli ziemskiej naszej Rzeczypospolitej: niech żyje w setne Matuzelowe lata (szlachta, II poł. XVIII w.) WójDw 119;

Wypijmy zdrowie największego poety polskiego, który tak pięknie wyraził nasze uczucia (starosta, toast za Stanisława Trembeckiego, II poł. XVIII w.) RzewLis2, 242;

${ }^{1}$ M. Marcjanik, Polska grzeczność językowa, Kielce 2000, s. 145.

${ }^{2} \mathrm{O}$ toastach-przemówieniach: M. Marcjanik, Współczesne polskie toasty-przejawem pauperyzacji życia towarzyskiego, [w:] Język a kultura, t. 5, Potoczność w życiu i kulturze, red. J. Anusiewicz, M. Marcjanik, Wrocław 1992, s. 191-201.

${ }^{3}$ D. Bula, J. Nawacka, Próba klasyfikacji aktów mowy, „Socjolingwistyka” 1983, t. 5, s. 41.

${ }^{4}$ M. Cybulski, Obyczaje jezzkowe dawnych Polaków. Formuly werbalne w dobie średniopolskiej, Łódź 2003, s. 218.

5 Świadczy o tym choćby taki, pochodzący z osiemnastowiecznej komedii dialog:

- Nalej. Podobno i ja się napiję.

- Życzę. Będziesz waszmość pan zdrowszy. BohK2, 123. 
Kochany poruczniku! [...] Piję najprzód zdrowie twoje a z nim razem i twego dzielnego kapitana (szlachcic do porucznika, pocz. XIX w.) WójN 59;

Wznoszę zdrowie dobosza naszej poezyi pana Mikołaja Epsteina (przyjęcie młodych literatów, I poł. XIX w.) BrzostCK 49.

Toasty zawierające wyrażenie przyimkowe:

Piję dziś za szczęśliwe twoje przybycie, kochany Macieju (szlachta, II poł. XVIII w.) WójDw 85;

Wypijmy panie Macieju na pamiatkę dawnych czasów (szlachta, II poł. XVIII w.) WójDw 47;

Wypijmy duszkiem za zdrowie kochanego Kazimierza. Szczę́liwszy on i szanowniejszy jest z swoją prostotą niżeli drudzy z dworszczyzną i dowcipem (studenci, I poł. XIX w.) DmochWsp 125.

Powyższe przykłady dowodza, że częstym i ważnym elementem obudowy tego typu toastów były komplementy, dowartościowujące odbiorcę.

2. Innym sposobem redukcji pierwszego członu było ominięcie czasownika i pozostawienie samego dopełnienia, obudowanego ewentualnie wokatywnymi formami adresatywnymi:

Mości panie Pogromski! do waćpana - stateczna przyjaźń (szlachta, II poł. XVIII w.) KK 97;

Do waszmość pani (szlachta, II poł. XVIII w.) BohK2, 129;

Dla ciebie jenerale (książę Józef Poniatowski, kon. XVIII w.) PamGąs 97 wyjątkowo przyimek dla zastępuje standardowe do;

Do waćpana, panie bracie (szlachta, I poł. XIX w.) SkarbDod 119;

Do was. Dobrego zdrowia! Na zdrowie wam! (chłopi, lata 40. XIX w.) KraszU 69 - dodatkowo po toaście pojawiają się życzenia.

3. Możliwe było też całkowite pominięcie członu pierwszego i pozostawienie samego okolicznika?:

Za zdrowie szanownego i szczerego gospodarza Karola Radziwiłła (Stanisław August Poniatowski, II poł. XVIII w.) PamRadz 66;

Za zdrowie JW teraźniejszego i da Bóg doczekać przyszłego naszego Marszałka (szlachta, przeł. XVIII/XIX w.) BykPam1, 224;

Za twoje zdrowie, dzielny wojaku (mieszczka do żołnierza, I poł. XIX w.) MicPam 91;

$W$ zdrowie naszego kuma Dmytra (uboga szlachta w karczmie, poł. XIX w.) ŁozDw 305;

Za zdrowie wszystkich pięknych wdówek (szlachta, poł. XIX w.) KorzDram 237;

Za zdrowie Bronisławy i Celiny (szlachta, poł. XIX w.) CieszT2, 92.

${ }^{6}$ E. Umińska-Tytoń, Komplementy czyli piękne słówka, [w:] Piękno duchowe, piękno materialne, red. A. Tomecka-Mirek, Łódź 2004, s. 707.

${ }^{7}$ Według M. Cybulskiego był to rezultat dużej frekwencji formuły. M. Cybulski, Obyczaje językowe..., s. 220. 
4. Wreszcie ostatnim etapem redukcji formuł była likwidacja przyimka w okoliczniku, co skutkowało utratą pierwotnej funkcji składniowej. Zebrany materiał świadczy o tym, że te dobrze znane i dziś toasty były rozpowszechnione już w początkach epoki nowopolskiej:

Zdrowie pana Brzostowskiego drugiego posła naszego (szlachta na sejmiku, II poł. XVIII w.) ChodźPam 40;

Zdrowie! JW Sielickiego (wojewoda na sejmiku, II poł. XVIII w.) ChodźPam 38;

Zdrowie wojewody dobrodzieja (wojski, II poł. XVIII w.) ChodźKon 58;

Zdrowie księcia pana (szlachta, II poł. XVIII w.) PamOch 281;

A więc zdrowie solenizantki (szlachta, pocz. XIX w.) ChodźKon 266;

A więc zdrowie twoje, kochany nasz wojski dobrodzieju (wojewoda, II poł. XVIII w.) ChodźKon 81;

Zdrowie księdza kanonika (baron, I poł. XIX w.) Kpt 186;

Zdrowie od nas ukochanego podpułkownika Trębickiego (komendant pułku, 1815) DzBar 131;

Zdrowie nieprzytomnego hrabiego Krynickiego (szlachcic, lata 20. XIX w.) OlPam1, 61;

Zdrowie pana Grafa (cześnik, lata 20. XIX w.) OlPam1, 235;

Zdrowie ślachty i braci chłopków (szlachcic, lata 30. XIX w.) OrWęd 126;

Zdrowie p. podczaszego dobrodzieja miłego a rzadkiego gościa (szlachta, lata 40. XIX w.) CieszT1, 211;

Zdrowie twoje Bartłomieju (rybacy, lata 40. XIX w.) RusWar4, 123;

Zdrowie naszej madam (mieszczaństwo, lata 40. XIX w.) KuWar3, 34;

Dam zdrowie (szlachta, lata 40. XIX w.) DzierzD2, 156;

Zdrowie kochanego gospodarza naszego (szlachcic, poł. XXI w.) DmNa 46.

Redukcji formuł toastów towarzyszyło obniżenie ich rangi towarzyskiej. Najbardziej rozbudowane formuły, zawierające element werbalny i komplementy stosowano wśród wyższych warstw społecznych: szlachty i ludzi wykształconych. Natomiast akty zredukowane były bardziej uniwersalne - używali ich również chłopi i mieszczanie oraz uboga szlachta.

\section{2. „NIECH ŻYJE...” - WIWATY W FUNKCJI TOASTÓW}

Nie wszystkie toasty miały charakter życzeń. W ekscerpowanych tekstach pochodzących z XIX wieku czasami rolę toastów pełnią wiwaty. Okrzyki wznoszono zarówno na cześć konkretnych osób (np. solenizanta) jak i całych stanów:

Niech żyje! (toast na cześć Seweryna Goszczyńskiego, I poł. XIX w.) BrzostCK 49;

Niech żyje wojsko! (szlachta, 1815) DzBar 179;

Niech żyjq obywatele (wojskowi, 1815) DzBar 179; 
Niech żyje namiestnik (szlachta na balu, 1815) DzBar 189;

Niech żyje pamięć nieśmiertelna księcia Józefa (szlachta, 1815) DzBar 131;

Stan obywatelski niech żyje! (szlachta, lata 40. XIX w.) DzierzD2, 156;

Niech żyje p. Wykowska dobrodziejka, nasza długoletnia sąsiadka (szlachta, lata 40. XIX w.) CieszT1, 211;

Wiwat! Niech żyje prezes i pan aptekarz (mieszczanie, lata 60. XIX w.) CieszT1, 74.

\subsection{INNE FORMY}

W przypadku pozostałych toastów pochodzących z badanych tekstów trudno mówić o jakiejkolwiek ich formuliczności. Akty te mają bardzo indywidualny charakter, a ich treść często uwarunkowana jest konkretnymi okolicznościami:

Król z narodem, naród z królem (Karol Radziwiłł w czasie uczty, II poł. XVIII w.) PamRadz 66;

Kochajmy się bracia i siostry jako jednej matki synowie i córki (Stanisław August Poniatowski na uczcie u Karola Radziwiłła, II poł. XVIII w.) PamRadz 66;

Byłego w moim regimentarzu podporucznika, a teraz łaską królewską na stopień majora głównego sztabu i przybocznego adjutanta Jego królewskiej Mości, Wejsenhofa, abym go na najwyższych stopniach godności oglądał (Karol Radziwiłł, II poł. XVIII w.) PamRadz 108;

Pamięci mężnych braci i towarzyszy twoich! toast szczery kapitanie (szlachcic, pocz. XIX w.) ChodźKon 269;

Na lepsze czasy! żeby licha nie znać! (uboga szlachta w karczmie, poł. XIX w.) ŁozDw 305.

\subsection{UWAGI KOŃCOWE}

W początkach doby nowopolskiej najbardziej rozpowszechnione wśród wszystkich warstw społecznych toasty mają bardzo prosta, wręcz ubogą formę, która jest wynikiem maksymalnej redukcji staropolskich formuł. Sytuacja picia alkoholu najwyraźniej nie sprzyjała długim przemowom i stąd rzadko były one amplifikowane.

W zebranym materiale niemal w ogóle nie występują popularne jeszcze w okresie średniopolskim formuły o genezie modlitewnej zawierające 2 . osobę czasownika typu Boże daj zdrowie. Jedyny ślad po nich znajdujemy w rymowanym toaście, który miała wznieść swatka po udanych pertraktacjach z rodzicami panny:

W tym kieliszku kropel ile,

Daj Boże szczęścia tyle (I poł. XIX w.) HoffOpis 177. 


\section{PRZEDSTAWIANIE KOGOŚ, PRZEDSTAWIANIE SIE}

Dawne zasady grzeczności wymagały, by prezentacji dokonywała osoba znana obu stronom - nie wypadało przedstawiać się samemu, szczególnie obcy mężczyzna nie mógł sam przedstawiać się kobiecie ${ }^{1}$. W praktyce spełnienie tego wymogu etykiety nie zawsze było możliwe, choćby z powodu braku pośrednika i konieczne okazywało się samodzielne dopełnienie aktu prezentacji. Nieprzypadkowa była też kolejność: stosowano znane i dziś ${ }^{2}$ reguły, by osobę o niższej randze pragmatycznej przedstawiać ważniejszej oraz kobiecie mężczyznę.

\section{1. „PREZENTUJĘ/REKOMENDUJĘ/PRZEDSTAWUJĘ” I PRZEKSZTAŁCENIA}

Najczęściej ośrodkiem formuły służącej do zapoznawania obcych sobie osób był czasownik prezentować. Rekomendować i powszechnie dziś stosowane przedstawiać były używane zdecydowanie rzadziej:

Rekomenduje panu staroście mego dobrego przyjaciela, pana Stanisława Płaskowickiego, podczaszego nowogródzkiego (książę Radziwiłł, II poł. XVIII w.) RzewLis 1, 134;

Mości książę, przedstawuję waszej pasterskiej mości pana starostę wileńskiego, zapewne dobrze mu znanego w Warszawie (książę Radziwiłł do biskupa wileńskiego, II poł. XVIII w.) RzewLis1, 139;

Prezentuję waszmość panom bardzo godnego kawalera (szlachcic do przyjaciół, II poł. XVIII w.) BohK1, 458;

Mości panowie, prezentuję tego kawalera, jest godzien ich poznania (szlachcic do przyjaciół, II poł. XVIII w.) BohK1, 453;

Prezentuję Imość Pani młodego księcia Melsztyńskiego, który najżywiej pragnie być jej znajomym (starościc do szlachcianki, II poł. XVIII w.) WirMal 49;

Prezentuję księciu pana Ochockiego, mającego przyjaźne i dawne z tym domem stosunki (arystokrata, II poł. XVIII w.) PamOch2, 239;

Kochana Feluniu, prezentuje ci syna mego brata (szlachcianka do znajomej, I poł. XIX w.) KorzOk 31;

Prezentuje panu mego sąsiada, pana Wojskiego Ryńskiego (hrabia do grafa, lata 20. XIX w.) OlPam1, 157;

${ }^{1}$ E. Umińska-Tytoń, Polszczyzna dziewiętnastowiecznych salonów, Łódź 2011, s. 171.

${ }^{2}$ H. i T. Zgółkowie, Językowy savoir-vivre. Praktyczny poradnik poslugiwania się polszczyzna w sytuacjach oficjalnych i towarzyskich, Poznań 1993, s. 48. 
Prezentuję panu moją dziewkę (ubogi szlachcic do bogatego, lata 20. XIX w.) OlPam1, 39;

Prezentuję ci mego od serca przyjaciela, Ignacego Pawszę (mąż do żony, I poł. XIX w.) BłP 244;

Oto jest Kisielek, mój przyjaciel, którego ci rekomenduje (mąż do żony, I poł. XIX w.) BłP 242;

Prezentuję Pani Dobrodzice moją córkę, którą nie widziałeś jeszcze odkąd wróciła z pensyi (szlachcianka do znajomej, lata 40. XIX w.) DzierzD1, 31;

Prezentuje panom nowonarzeczonych (podkomorzanka do szlachty, poł. XIX w.) BujSt 287;

Rekomenduję panu, to mój sąsiad, rządca buczalskiego folwarku, pan Girgilewicz (sędzia do gościa, poł. XIX w.) ŁozDw 54.

W ekscerpowanych tekstach oprócz takich prostych i krótkich formuł, w których jedynym elementem etykietalnej obudowy były formy adresatywne, zdarzają się także prezentacje bardziej wyszukane, wzbogacone o ceremonialne zwroty honoryfikatywne:

Mam honor prezentować moich przyjaciół, którzy z łaski swojej chcieli mi tu akompaniować z Warszawy (szlachcic do rodziny narzeczonej, II poł. XVIII w.) KK 151;

Pozwolicie waszmość państwo, żebym miała honor prezentować Doranta, wuja Elizy (szlachcianka do znajomych, II poł. XVIII w.) CzarKom 350;

Mam honor przedstawić państwu nowego kasztelana wileńskiego (generał do szlachty, I poł. XIX w.) KorzKom 235;

Mam honor prezentować panom pana Erazma Prawdzickiego (arystokrata do przyjaciół, I poł. XIX w.) DzierzS 34;

Niech pani tylko zezwoli na to, ażebym Ci teraz mego narzeczonego przedstawita (szlachcianka do znajomej, I poł. XIX w.) SkarbSt 103;

Mam zaszczyt przedstawić Państwu moją małżonkę i daleką kuzynkę (szlachcic do baronostwa, lata 40. XIX w.) RusWar2, 85;

Mam honor zarekomendować panu pana Czorguta, przyjaciela naszego dziedzica (sędzia do rządcy, poł. XIX w.) ŁozDw 240.

W badanych tekstach trudno ustalić jakąś ścisłą zależność między rangą odbiorcy a poziomem honoryfikatywności zastosowanego aktu przedstawiania. Wydaje się, że sytuacje oficjalne sprzyjały stosowaniu bardziej uroczystych formuł. W codziennych kontaktach preferowano krótkie prezentacje.

\subsection{INNE FORMY}

W badanym okresie stosowano niekiedy również bardzo proste akty z elipsą czasownika być: 
To towarzysz mój, pani, co na szkolnej ławie przesiedział ze mną długo (szlachcic do znajomej, I poł. XIX w.) KorzKom 260;

A to pan sprawnik [naczelnik policji] z Dubna, a to pan strapczy [kancelista] z Żytomirza (szlachcic do szlachcianki, I poł. XIX w.) BłP 330;

Moi rodzice, moja siostra (mieszczanin do barona, poł. XIX w.) KraszDz 44.

Rzadko podczas prezentacji używano czasownika poznać:

Pozwól mości starosto żebym WPana poznat z moją siostrą, Morawską, gospodynią mojego domu (książę, II poł. XVIII w.) RzewLis1, 139;

Poznajcie się panowie: pan Justyn z Poddubiniec i pan Aleksy Drabicki (ksiądz do szlachty, poł. XIX w.) KraszDwa 199.

\subsection{FORMUŁY PRZEDSTAWIANIA SIE}

Materiał jest tu ubogi, bo jak już wspomniano, samodzielne przedstawianie się nie należało do dobrego tonu³. Czasem było to jednak konieczne. Takie akty prezentacji cechuje zwykle duża prostota:

Ja jestem Jacek Dzierzanowski (szlachcic do szlachcica, II poł.XVIII w.) WójDw 36;

Jestem rodzony siostrzeniec Waćpani Dobrodziki, nazywam się Tarczewski (szlachcic do wujenki, pocz. XIX w.) KuKas 169;

Jestem Antoni Pradecki (szlachcic do córki leśniczego, lata 60. XIX w.) CieszP 99.

Bardziej rozbudowane formuły zawierały honoryfikatywną frazę werbalną:

Mam honor rekomentować (sic!) się - Mateusz Strzemionczek (szeregowiec do żony lokaja, I poł. XIX w.) KorzSt 67;

Winienem panu doktorowi zaprezentować się. Nazywam się Jan Walter (mieszczanin do lekarza, poł. XIX w.) KraszDz 105.

Samodzielne prezentacje obudowywano także aktem ofiarowania służb:

Skołuba, do ustug pańskich (szlachcic do szlachcica, II poł. XVIII w.) RzewLis 112 ;

Tymoteusz Brzydkiewicz, do usług jaśnie wielmożnego pana (szlachcic do prezesa, I poł. XIX w.) KorzKom 60.

${ }^{3} \mathrm{O}$ tym jak dalece ten przepis savoir-vivre'u był przestrzegany nie tylko w Polsce świadczy fragment wspomnień z lat 30. XIX w. Józefa Zielińskiego: „Anglik [...] obecny na jednym z głośnych wieczorów u księcia Czartoryskiego w Paryżu, grzejąc się przy kominku obok nieznajomej sobie osoby, spostrzegł, że frak tego sąsiada od gorąca się zatlił. Z flegmą angielską spojrzał mu w twarz, aby się przekonać czy go nie zna, a następnie spostrzegłszy w kole tańczących jednego ze swych znajomych, zbliża się do niego i rzecze: »Znasz Pan tę osobę, co się grzeje przy kominku?« — »Znam, to jest pan W. - lecz dlaczegóż to pytanie? « - Hau dobrze, bardzo dobrze, to bądź łaskaw powiedzieć mu, że się jego suknia pali!« - „Och! Czy być może! Ale czemuż Pan go sam nie ostrzegłeś natychmiast?« $-» H m n$, bo ja mu nie byłem przedstawionym. «" ZielWsp 62. 


\subsection{ODPOWIEDZI}

W odpowiedzi na formułe prezentacji wypadało wyrazić radość z poznania przedstawianej osoby. Akty, które występują w tej funkcji w badanych tekstach, są bardzo konwencjonalne, a większość z nich można usłyszeć również dziś4:

Bardzo mi przyjemnie, żem poznała moją kuzyneczkę (szlachcianka, pocz. XIX w.) DemD 77;

Bardzo mi przyjemnie poznać pana Tachlewicza (szlachcic do szlachcica, poł. XIX w.) ŁozDw 240;

O bardzo jestem rad, że poznaję pana Grafa (marszałek, pocz. XIX w.) OlPam1, 57;

Bardzo rada jestem poznać tak dystyngowanego oficera (starościna, pocz. XIX w.) WójN 24;

Miło mi więc pana poznać, i proszę o jego przyjaźń (szlachcic do szlachcica, lata 40. XIX w.) DzierzD1, 104;

Lubię młodzież, miło mi poznać pana (hrabia do młodzieńca, poł. XIX w.) KraszDwa 118.

${ }^{4}$ Wbrew zaleceniom współczesnych podręczników dobrych manier, których autorzy twierdzą zwykle, że takie formuły wyszły już z mody. J. Kamyczek, Grzeczność na co dzień, Warszawa 1974, s. 25 . 


\section{FORMUŁY UŻYWANE PRZY WRĘCZANIU}

W okresie średniopolskim repertuar formuł, które stosowano przy okazji darowania jakiegoś dobra, był bogaty i zróżnicowany funkcjonalnie: istotny był przedmiot podarunku oraz relacje społeczne między ofiarodawcą a obdarowanym ${ }^{1}$. W początkach doby nowopolskiej wariantywność formuł zarówno ustnych jak i epistolarnych jest niewielka. Zdecydowana większość zebranego materiału zawiera w różnej postaci czasownik przyjąć.

\subsection{FORMUŁY ORALNE}

\subsection{1. „przyjmij’ i przekształcenia}

Najprostsza postać formuł kierowanych do osób obdarowywanych zawierała syntetyczną formę trybu rozkazującego. Grzeczność takich aktów zwiększano przez dodawanie adresatywów lub obudowanie prośbą. Stosowano je zarówno w relacjach symetrycznych, jak i wtedy, gdy interlokutorów dzieliła różnica rang. Większość odnotowanych użyć pochodzi z pierwszego półwiecza badanego okresu:

Moje dziecko, przyjmij te kwiaty, które na mojem oknie wyrosły (zakonnik do młodej szlachcianki, II poł. XVIII w.) WirMal 70;

Przyjm waszmość pan, tę przysługę, proszę uniżenie (guwerner do ekonoma, dając mu tabakierkę, II poł. XVIII w.) BohK1, 192;

Przyjmij, panie, te dary małego szacunku (chłopi do pana, oddając mu wieńce dożynkowe, II poł. XVIII w.) WybDr 276;

Przyjm na pamiątkę mojej przyjaźni z życzeniem, obyś go nigdy nie dobył bez potrzeby, a nie schował w pochwę bez honoru (pułkownik do szlachcica, darując mu pałasz, II poł. XVIII w.) KoźPam1, 251;

Przyjmijże ten mały udział od przyjaciela twego, który będzie rękojmią wzajemnej naszej przyjaźni (biskup do majora, dając mu zegarek i tabakierkę, kon. XVIII w.) PamGąs 222;

Przyjm proszę tę małą bagatel, którą ci szczery przyjaciel z życzliwego serca ofiaruje (biskup do prowincjała, wręczając dukaty, kon. XVIII w.) PamGąs 192;

Proszę, przyjmij to od rodaka (książę Józef Poniatowski dając podarunek żonie oficera, pocz. XIX w.) KoźPam2, 27.

${ }^{1}$ M. Cybulski, Obyczaje językowe dawnych Polaków. Formuly werbalne w dobie średniopolskiej, Łódź 2003, s. 183. 
Jedynie raz tryb rozkazujący został zastąpiony oznajmującym w czasie przyszłym²:

A pan Ochocki przyjmie odemnie konia, którego lubi, na którym przy mnie pracował, jako pamiątkę i oznakę mojej wdzięczności za muzykę dla moich kochanych kozaków (książę do szlachcica, kon. XVIII w.) PamOch2, 218.

Aktowi wręczania mogły również towarzyszyć bardziej rozbudowane formuły zawierające konstrukcje analityczne charakterystyczne dla próśb:

Proszę przyjać za dowód mojej szczerej przyjaźni i szacunku dla niej (hetmanowa wręczając podarunek stolnikowej, kon. XVIII w.) PamGąs 61;

Racz WKsiążęca Mość przyjać ode mnie dla niej 150 jeźdźców z końmi (szlachcic do księcia Józefa Poniatowskiego, pocz. XIX w.) KoźPam2, 15;

Panie pułkowniku, racz przyjać w darze od przywiązanego zięcia klejnot mojej stajni, piękną, czystej krwi Rachelę (pocz. XIX w.) WójN 243;

Raczcie panie przyjąć moją usługę (szlachcic do dam, I poł. XIX w.) KorzKol 10.

Zebrany materiał, choć skromny, pokazuje jednak, że w badanym okresie takie bardziej ceremonialne akty stosowano nie tylko w sytuacjach uroczystych, gdy wręczany dar był bardzo znaczny, ale także w zwykłych salonowych rozmowach.

\subsubsection{Inne formy}

Frazy zawierające czasowniki inne niż najczęściej spotykane przyjmować należą do rzadkości:

Pozwolisz mi waćpanna dobrodziejka prezentować sobie słoik pomady do ust (szlachcic do panienki, II poł. XVIII w.) CzarKom 99;

Weź tę bagatelę, którą ci daje przyjaciel (komisarz do powstańca, dając mu sakiewkę z pieniędzmi, I poł. XIX w.) LewPam 86 - w dobrym tonie było także umniejszanie wartości dawanego prezentu.

Wręczanie czegoś mogło być także okazją do wygłoszenia krótkiej oracji:

Przyjacielu! Z największą wprawdzie boleścią serca mego daję ci ten prezent smutny ale $\mathrm{w}$ teraźniejszym czasie potrzebny tobie, abyś za pomocą tych kul, mógł prędszą odzyskać moc nóg twoich, na dalsze ojczyzny usługi bardzo potrzebnych. $\mathrm{Z}$ tą jednak kondycja, gdy już pomocy ich potrzebować nie będziesz, abyś mi je wrócił, które jak relikwie w domie moim na zawsze pozostaną (stolnik do adiutanta, kon. XVIII w.) PamGąs 34.

${ }^{2}$ Ibidem, s. 186. 


\subsection{FORMUŁY LISTOWNE}

W korespondencji chętniej stosowano formuły dłuższe, a więc posiadające wyższą wartość honoryfikatywną. Nawet jeśli pojawiają się formy trybu rozkazującego, to akty je zawierające mają postać rozbudowanych wypowiedzi, starannie obudowanych wieloskładnikowymi adresatywami:

Synu szanownych i zacnych w kraju Rodziców, i mój chrzestny! Przyjmij ten odemnie ojca twego chrzestnego mały upominek, mego ku tobie przywiązania i wysokiego szacunku i uszanowania dla twoich godnych rodziców (szlachcic przesyłając dukaty, 1793) PamGąs 29;

Przyjmij, Kochany, a tak mnie życzliwy Panie Józefie, takim sercem, jakim ci ofiaruję, a bądź przekonany, że cię nie po literacku, ale po prostacku najprawdziwiej kocham (Teofil Lenartowicz do Józefa Kraszewskiego wysyłając mu swój wiersz, 1858) LenarKor 23.

Częściej jednak, szczególnie w listach do osób posiadających wysoką ranę pragmatyczna, stosowano formuły zawierające formalne wykładniki prośby:

Racz WKMć dobrotliwie przyjać ten mały upominek, a łaskawymi względy wzmagać starego i wiernego sługę swojego (Ignacy Krasicki do króla, 1780) KKor1, 412;

Niech Pani raczy przyjąć ode mnie i od mojej żony, ostatnią pamiątkę po Janie Śniadeckim (szlachcic do hrabiny, 1830) ŚniaLis 205;

Teraz proszę przyjać do swojego zbioru książkę lubo nie stara, ale dosyć ważną pod względem dat (Wincenty Pol do arystokraty, 1839) PolLis 41;

Racz przyjać na pamiąteczkę te kamyczki (Zygmunt Krasiński do przyjaciela, 1839) KrasMał 1.

Niespotykane w ekscerpowanych tekstach formuły, których jądrem jest czasownik składać, zaleca S. Szymański w swoim listowniku:

Pierwsze dary, któremi przysłużyła mi się moja Flora, składam w ręku Wmć Panny (przy posłaniu damie bukietu);

$\mathrm{Z}$ własnego mego ogródka, własnej uprawy i pracy owoce składam w ręku Wmć Pana (przy posłaniu owoców).

${ }^{3}$ S. Szymański, Wzory biletow, listow i memoryałow w rożnych materyach z przydatkiem uwag w powszechności o stylu listownym przypisków względem szczegulnych listów gatunkow i drobnych przestrog względem formalności w pisaniu, t. 1, Warszawa 1784, s. 75-76. 


\section{KONDOLENCJE}

W ekscerpowanej korespondencji jedynie kilkakrotnie pojawiają się wyrazy współczucia z powodu śmierci bliskiej dla adresata osoby. Wszystkie odnotowane użycia są późne - pochodzą z końca badanego okresu. Inaczej niż w okresie średniopolskim ${ }^{1}$, trudno w zebranym materiale znaleźć choćby ślad stałych formuł, za pomocą których składano kondolencje. Są to teksty formalnie bardzo mocno zindywidualizowane i stosunkowo długie. Cechy wspólne możemy obserwować jedynie na płaszczyźnie treści, która zawsze wyraża smutek, żal i współczucie:

Sq chwile w życiu, których powszedniq skala czasu nie można mierzyć. Sa boleści, o których mówić nie można, sam jestem ojcem i rozumiem Panie Twe serce i boleść Twa, rozumiem to, iż nie ma słów, któreby mogły przynieść pociechę, a nawet, gdyby byty, nie chciatbym, żeby te stowa przeszly przez usta moje - bo po stracie drogich osób nic nie zostaje nam pono droższego, jak pamięć i żal po nich. [...] Gtęboko czuję nas Twym nieszczęśsiem Panie! (Wincenty Pol w liście do znajomego, któremu zmarł syn, 1843) LisPol 105;

Matko szanowna, wszyscy tu obecni przyjaciele śp. Napoleona taczymy sie do żalu Twojego, błagając Miłosierdzia Bożego, abyś, wypłacając dtug naturalnej miłości macierzyńskiej, stanęła z nami razem przed Bogiem w ofierze chrześcijańskiej (zakonnik do matki zmarłego przyjaciela, 1850) LisDuń 89;

Oświadcz Pan panu Kochowi najgłębszy mój ból i Pani Krasińskiej z powodu nieszczęścia niepowetowanego, które go dotknęło, a mnie wydarło jedna z osób, do których od dzieciństwa serce me byto przywykto być przywiazane. Powiedz mu Pan ode mnie, że takie rany tylko leczy wiara silna, że się w innym świecie odnajdzie ukochanq istote (kondolencje po śmierci żony, 1852) KrasLis 67;

Dla brata Ludwika współczucie dla jego boleści łaczymy, Boga miłosiernego błagajac, aby go pocieszyt i ukoit (kondolencje po śmierci dziecka, 1854) LisDuń 243;

Cóż ci powiem? co napiszę? Alboż tzami pisać można, kiedy prawdziwe, a choćbym co i pisat, czyżby słowo jakie moje tobie pomódz mogło? Na takie bóle, nic, co z ziemi, nie pomaga na ziemi, prócz czasu (Zygmunt Krasiński do syna Kajetana Koźmiana, kondolencje z powodu śmierci ojca, 1856) KrasSł 142.

W listowniku M. Korzeniowskiego uwzględniono całą kategorię „listów pocieszających", które obejmują nie tylko przypadki śmierci, ale także takie nieszczęścia jak gradobicie, utrata urzędu, ciężka choroba, pożar itp. W podanych wzorach listów również jednak nie znajdziemy żadnych utartych formuł.

${ }^{1}$ M. Cybulski, Obyczaje językowe dawnych Polaków. Formuly werbalne w dobie średniopolskiej, Łódź 2003, s. 224-226. 
Autor we wstępie pisze, że: „W tym rodzaju listów piszący okazać ma, ile sam czuje nieszczęście, w którem drugiego pocieszać pragnie; ton i sposób mówienia nie powinien być suchy, ani taki, który wymaga koniecznie, aby smutny stał się natychmiast wesoły, bo nic nie boli bardziej nieszczęśliwego, jak to, kiedy mu płakać zabraniają". Być może w badanym okresie wszelka konwencjonalność w przypadku tak tragicznych okoliczności była uważana za niestosowną.

${ }^{2}$ M. Korzeniowski, Pisarz listów powszechny: wybór wzorowych listów we szelkich stosunkach i okolicznościach potocznego życia : wzory przedstawień do władz rzqdowych, wekslów, obligów, kontraktów, cessyi, testamentów, rozmaitych zapisów, zaświadczeń, wszelkich aktów urzędowych i.t.p., Wrocław 1847, s. 171. 


\section{PODSUMOWANIE}

\subsection{ZWIAZZEK Z TŁEM HISTORYCZNYM I KULTUROWYM EPOKI}

Zebrany i zanalizowany w niniejszej pracy materiał pozwala stwierdzić, że pierwszy wiek doby nowopolskiej, to czas zasadniczych zmian w polskiej etykiecie językowej. O ile okres średniopolski był epoką wzbogacania struktur ${ }^{1}$, to w badanym czasie wyraźna jest tendencja do ich upraszczania. Widoczne staje się odejście od typowych dla baroku mocno amplifikowanych formul, w których pełna ornamentów obudowa etykietalna często dominowała nad ich werbalnym jądrem. W ekscerpowanych tekstach długie i pełne ozdobników akty są już rzadkością.

Okres ten przyniósł istotne reformy w systemie edukacji, szczególnie szlachty. Jezuickie kolegia, uczące przede wszystkim łaciny i retoryki, zastapiono szkołami świeckimi, w których zwalczano makaroniczne inkrustracje oraz kładziono nacisk na umiejętność posługiwania się jasnym i czystym językiem polskim. Inaczej niż w poprzedniej epoce, latynizmy w formułach grzecznościowych są rzadkością. Wśród szlachty, a zwłaszcza w środowiskach arystokratycznych, widoczna za to staje się moda na galicyzmy - w badanych tekstach łatwiej np. spotkać adieu niż polski odpowiednik tego pożegnania, chętnie używano również francuskich form adresatywnych. Natomiast w ekscerpowanych źródłach nie odnaleziono przejawów wpływu na polską etykietę języków państw zaborców rosyjskiego i niemieckiego.

Doba oświecenia bywa nazywana wiekiem rozumu, dominujące wówczas nurty filozoficzne to racjonalizm i empiryzm. Wyraźna staje się też sekularyzacja państw europejskich. Być może wszystkie te czynniki wpłynęły na zjawisko zanikania wielu formuł etykietalnych o genezie modlitewnej - niektóre przestają być w ogóle używane (np. powitania pomaga Bóg, Boże daj, by zdrów byl, zdarz Bóg), a w innych element wskazujący na religijne źródło aktu uległ elipsie (np. dzień dobry, dobry wieczór). Czasem, jak w przypadku powszechnie stosowanego jeszcze w okresie średniopolskim podziękowania Bóg zapłać, czy pożegnania Idź z Bogiem zawężony zostaje zasięg użycia takich formuł do niższych warstw społecznych.

Badane stulecie obejmuje także okres romantyzmu, który był reakcją na społeczne i polityczne zmiany spowodowane ruchami nacjonalistycznymi i wolnościowymi, nawiązującymi do rewolucji francuskiej. Romantycy zakwestionowali podstawy oświeceniowego, racjonalistycznego spojrzenia na świat. Zwrócili

${ }^{1}$ M. Cybulski, Obyczaje językowe dawnych Polaków. Formuly werbalne w dobie średniopolskiej, Łódź 2003, s. 239. 
uwagę na życie wewnętrzne człowieka: uczucia, emocje i wyobraźnię. Podkreślali wagę indywidualizmu, zerwali ze sztywnymi poprawnościowymi normami wypracowanymi przez doktrynę klasycyzmu². Nie dziwi zatem, że w ekscerpowanych tekstach, szczególnie w korespondencji, częstym zjawiskiem są indywidualnie przekształcone formuły etykietalne, czy wręcz zupełnie odbiegające od znanych schematów akty będące wyrazem emocji piszącego. Niektóre nieszablonowe frazy tworzono specjalnie na potrzeby pewnych grup, szczególnie tajnych, w których mogły one pełnić zarówno funkcję integrująca, jak i być rodzajem hasła - np. charakterystyczne powitania powstańców listopadowych czy oryginalne salutacje w listach członków Związku Filomatów i Filaretów.

\subsection{ASPEKT FORMALNOJEZZYKOWY}

Choć w pierwszym stuleciu doby nowopolskiej niewątpliwie dominującym zjawiskiem jest upraszczanie formuł etykietalnych, to jednak możemy też zauważyć przeciwstawną tendencję do ich amplifikowania.

Zmiany formalne, które zachodzą w aktach grzecznościowych badanego stulecia, rzadko dotyczą werbalnego jądra formuły. Skracanie fraz polegało bowiem przede wszystkim na ograniczaniu elementów etykietalnej obudowy - akty grzecznościowe w analizowanym okresie zawierają zdecydowanie mniej ozdobników w postaci określeń przysłówkowych, rozbudowanych form adresatywnych i atrybutywnych oraz zwrotów honoryfikatywnych typu z taski swojej, mam honor niż w epoce średniopolskiej. Rzadziej redukcji ulegał wykładnik predykacji np. sktadam dzięki $\rightarrow$ dzięki; jestem stuga, mam honor zostać uniżona stuga $\rightarrow$ stuga. W badanym czasie zarzucono także chętnie wcześniej stosowany zabieg, polegający na rozbudowywaniu szeregów składniowych przez dodawanie synonimów, w wyniku czego powstawały frazy typu oddaję i ofiaruje, wnoszę suplikę i prośbę ${ }^{3}$.

Jednocześnie ekscerpowane teksty wyraźnie pokazały, że nadal chętnie amplifikowano człon werbalny za pomocą zwrotów honoryfikatywnych. Były to przekształcenia typu: jestem sługa $\rightarrow$ mam honor zostać uniżonym sługa; prosze $\rightarrow$ ośmielam sie prosić, prezentuje $\rightarrow$ mam zaszczyt prezentować, przebacz $\rightarrow$ racz przebaczyć. Innym sposobem wydłużenia i zwiększenia grzeczności formuły było obudowanie jej prośbą - w ten sposób pierwotnie akt autonomiczny tracił swoją samodzielność: kłaniam $\rightarrow$ proszę się kłaniać, daruj $\rightarrow$ proszę darować, przebacz $\rightarrow$ proszę mi przebaczyć, dziękuję $\rightarrow$ proszę przyjać dziękczynienie itp. Przedstawione tu zabiegi nie są niczym nowym - powszechnie stosowano je już w średniopolszczyźnie.

${ }^{2}$ A. Zdaniukiewicz, Spór o istotę kultury w pierwszej połowie XIX w., „Język Polski” 1979, R. LIX, s. 361-373.

${ }^{3}$ Ibidem, s. 243. 
Zwiększanie długości formuł było wynikiem ich pospolitowania się - amplifikacja służyła przede wszystkim przywracaniu utraconej mocy illokucyjnej aktu. Im częściej jakaś fraza była używana, tym szybciej traciła pierwotną wartość honoryfikatywną i ulegała konwencjonalizacji. Obowiązywała reguła, że dłuższa formuła wyraża wyższy stopień grzeczności, gdyż jej użycie wymaga więcej wysiłku - zgodnie z maksymą wspaniałomyślności G. Leecha „minimalizuj swoją korzyść; maksymalizuj swój koszt" ${ }^{4}$ ".

W poddanym eksploracji okresie zmienia się także repertuar autonomicznych aktów grzecznościowych. Trudno jednak mówić tu o jednoznacznym zubożeniu lub wzbogaceniu ich zasobu, gdyż z jednej strony wiele charakterystycznych dla poprzedniej epoki formuł etykietalnych zanika (np. zdarz Bóg, Boże stykaj, zalecam chęci, konferuję i wiele innych), ale z drugiej należy odnotować przyrost nowych, często oddających ducha epoki fraz (np. ściskam, całuję, daruj, nie gniewaj się). W przypadku niektórych aktów widoczne jest ich stopniowe zanikanie (np. odpuść, przepuść, stuga uniżony). Ich miejsce zajmują często formuły dziś powszechnie używane, a w okresie średniopolskim mało popularne np. przepraszam czy do widzenia.

Oprócz przekształceń formalnych warto też odnotować zmiany funkcjonalne. Możemy obserwować tu dwie przeciwstawne tendencje: $z$ jednej strony następowała specjalizacja, a $z$ drugiej rozszerzenie funkcji niektórych aktów. W dobie średniopolskiej czasem jedna formuła łączyła (z dzisiejszego punktu widzenia) kilka aktów np. badź zdrów było życzeniem w roli pożegnania a daj Bóg dobry dzień życzeniem pełniącym funkcję powitania. W okresie nowopolskim to już tylko konwencjonalne pożegnanie i powitanie - element życzeniowy przestał być odczuwany. $\mathrm{Z}$ innym zjawiskiem mamy do czynienia w przypadku formuł typu caluję raczki, upadam do nóg. Pierwotnie frazy te stosowano wyłącznie w listownych subskrypcjach, natomiast w badanym okresie występują również w roli powitań, podziękowań oraz ustnych pożegnań. Doszło także do utożsamienia formuł służących do proszenia i wydawania rozkazów. Wielofunkcyjne w badanym okresie są też formuły ofiarowania służb, które spotykamy w aktach częstowania, powitań oraz pożegnań.

\subsection{ASPEKT PRAGMATYCZNOJĘZYKOWY}

O ile okres średniopolski charakteryzowała ogromna staranność i skrupulatność w różnicowaniu form etykiety językowej ze względu na status społeczny rozmówców ${ }^{5}$, to pierwszy wiek doby nowopolskiej przynosi duże uproszczenie w tym zakresie. Rewolucja francuska, przyjęcie Deklaracji praw człowieka i obywatela oraz wydarzenia związane z Wiosną Ludów spowodowały zerwanie z feudalizmem i upowszechnienie idei demokratycznych. W XIX w. w Polsce

\footnotetext{
${ }^{4}$ G. Leech, Priciples of Pragmatics, London 1983, s. 132.

${ }_{5}^{5}$ M. Cybulski, Obyczaje językowe..., s. 258.
} 
rozpoczął się proces ważnych zmian społecznych - przejście od struktur stanowych w struktury klasowe ${ }^{6}$. O miejscu człowieka w hierarchii społecznej przestało decydować tylko jego pochodzenie i przynależność do określonego stanu. Wyznacznikiem społecznego statusu zaczęły być także majątek i wykształcenie. Powstała „nowa arystokracja” ludzi bogatych, ale nieposiadających tytułów: bankierów, przedsiębiorców, kupców. Wzrosła też rola mieszczaństwa.

Te ważne zmiany społeczne znalazły swoje odzwierciedlenie na gruncie etykiety językowej, która również uległa swoistej demokratyzacji. Dużą część omawianych $\mathrm{w}$ tej pracy formuł stanowią akty bardzo uniwersalne, stosowane niezależnie od statusu społecznego nadawcy i odbiorcy, w których jedynie pewne elementy etykietalnej obudowy subtelnie sygnalizują różnice rang interlokutorów. W badanym okresie dużą popularność zdobywają neutralne formuły werbalne, które w ogóle nie wskazują na miejsce partnerów w hierarchii społecznej np. dzień dobry, do widzenia, przepraszam. Często nawet obudowa etykietalna nie była wyznacznikiem relacji asymetrycznej. Pierwotnie wskazujące na niższy status nadawcy formy adresatywne (np. pan, dobrodziej), autoadresatywne (np. sługa, podnóżek), atrybutywne (np. wielmożny, miłościwy) i określenia przysłówkowe (np. pokornie, uniżenie) nie tylko uległy konwencjonalizacji, ale również rozpowszechniły się wśród niższych warstw społecznych. Tak samo jak w dobie średniopolskiej, chętnie powielano przede wszystkim te akty grzecznościowe, które były używane przez szlachtę a szczególnie arystokrację. Ważną rolę w szerzeniu formuł etykietalnych poza pierwotny zasięg społeczny odgrywała służba, która, naśladując sposób mówienia swych chlebodawców, rozpowszechniała je wśród niższych warstw społecznych. W rezultacie akty te szybko traciły swoją pierwotnie wysoką wartość honoryfikatywna.

Formuły werbalne, niegdyś sygnalizujące bycie poddanym, typu padam do stóp, ściskam nogi, całuje ręce, przestały być nośnikiem tego pierwotnego sensu i również uległy spospolitowaniu. Ciagła ich żywotność w badanym okresie pokazuje jednak, jak ważne były nadal komunikacyjne role pana i sługi - zwykle nadawca odgrywał rolę sługi, a adresatowi przypisana była rola pana, niezależnie od rzeczywistych rang interlokutorów. Był to przejaw respektowania jednej z podstawowych norm polskiej grzeczności, która zakłada umniejszanie roli nadawcy?

Nie oznacza to jednak, że w początkach doby nowopolskiej zupełnie przestaje być widoczna zależność między stosowanymi formami językowej etykiety a relacjami społecznymi wiążącymi partnerów interakcji. Oczywiście nadal inaczej zwracano się do osób o dużo wyższej randze pragmatycznej, aniżeli do niższych

${ }^{6}$ M. Rachwał, O przyczynach zmian systemu adresatywnego jezzyka polskiego $w$ XIX w., [w:] Język a kultura, t. 6, Polska etykieta językowa, red. J. Anusiewicz, M. Marcjanik, Wrocław 1992, s. 41-49.

${ }^{7}$ M. Marcjanik, Typologia polskich wyrażeń językowych o funkcji grzecznościowej, ibidem, s. 27-31. 
i równych sobie. Trudno jednak nie zauważyć, że zasady, którymi się przy tym kierowano, były zdecydowanie mniej sztywne i rygorystyczne niż w poprzedniej epoce. Nawet król coraz częściej rezygnował z zarezerwowanych dla monarchy szablonowych aktów na rzecz pewnej swobody.

Formul ceremonialnych i zgodnych z ówczesnymi schematami grzecznościowymi używano przede wszystkim w sytuacjach oficjalnych. W przypadku prywatnych rozmów i korespondencji, szczególnie jeśli nadawcę i adresata łączyła pewna zażyłość, chętnie przekształcano utarte frazy.

Na sposób amplifikowania formuł wpływał w dużej mierze typ kontaktu dłuższe i bardziej ceremonialne akty znajdujemy przede wszystkim w listach. Ustna odmiana języka dąży do redukcji znaków. Rozmowa ma też zwykle charakter spontaniczny, nie ma w niej miejsca na długie zastanawianie się, czy poprawki, jak w przypadku korespondencji.

W przytoczonym $\mathrm{w}$ niniejszej pracy materiale możemy jednak wielokrotnie obserwować wzajemne wpływy etykiety epistolarnej i konwersacyjnej. Zarówno w listach znajdujemy akty grzecznościowe typowe dla kontaktów ustnych (np. dzień dobry, dobry wieczór, witam, zlituj się), jak i w rozmowach te wywodzące się $\mathrm{z}$ formuł właściwych dla korespondencji (np. padam do nóg, całuję raczki, pozwolisz, raczysz, prosiłbym, zapraszam na, dziękuję, że). Do rzadkości należały frazy, których użycie ograniczało się do odmiany ustnej lub pisemnej języka. 


\section{BIBLIOGRAFIA}

\section{WYKAZ TEKSTÓW ŹRÓDŁOWYCH ZE SKRÓTAMI}

AktPodr - S. Dąbrowski, Aktorowie w podróży, Warszawa 1969.

BDr - J. Baudouin, Utwory dramatyczne, oprac. M. Wielanier, Warszawa 1966.

BielBon - R. Bielecki, A. Tyszka, Dat nam przykład Bonaparte, Wspomnienia i relacje żotnierzy polskich 1796-1815, t. 1-2, Kraków 1984.

BłP - H. Błędowska, Pamiatka przeszłości, oprac. K. Kostniewicz, Z. Makowiecka, Warszawa 1960.

BoCu -W. Bogusławski, Cud mniemany, czyli Krakowiacy i Górale, Wrocław 1954.

BogA - St. Bogusławski, Adwokat, komedio-opera w jednym akcie, Warszawa 1833.

BohK1 - F. Bohomolec, Komedie konwiktowe, oprac. J. Kott, Warszawa 1959.

BohK2 - F. Bohomolec, Komedie na teatrum, oprac. J. Kott, Warszawa 1960.

BolBez - B. Bolesławita, Bezimienna, Powieść z końca XVIII w., Kraków 1912.

BranLis - Listy Elizy z Branickich Krasińskiej z lat 1835-1876, oprac. Z. Sudolski, Warszawa 1995.

BrzostCK - A. Brzostowski, Ci, których znatem, Warszawa 1910.

BujSt - K. Bujnicki, Stara panna, Wilno 1855.

BukPam - S. Bukar, Pamiętniki z końca XVIII i poczatków wieku XIX, Warszawa [b.r.w.].

BykPam - J. Bykowski, Pamiętniki włóczęgi, z czasów przejścia XVIII do XIX wieku, t. 1-2, Warszawa 1872.

ChałLis - T. Chałubiński, Listy 1840-1889, oprac. A. Szwejcerowa, Wrocław 1970.

ChłP - K. Chłędowski, Pamiętniki, t.1, Wrocław 1951.

ChodźKon - I. Chodźko, Dwie konwersacye z przeszłości, Wilno 1857.

ChodźPam - I. Chodźko, Pamiętniki kwestarza, Warszawa 1901.

ChopKor - Korespondencja Fryderyka Chopina, oprac. B.E. Sydow, t. 1-2, Warszawa 1955.

ChrzPam - A. Chrząszczewski, Pamiętnik oficjalisty Potockich z Tulczyna, wydał, wstępem i komentarzem opatrzył J. Piechowski, Wrocław 1976.

CieszP - K. Cieszewski, Pozory, Lwów 1863.

CieszT - K. Cieszewski, Talizman, t. 1-2, Lwów 1862.

CzarKom - A. K. Czartoryski, Komedie, oprac. Z. Zahrajówna, Warszawa 1955.

DemD - H. Dembińska, Dwie epoki mego życia, Kraków 1841.

DmNa - F.S. Dmochowski, Nauczycielka. Powieść z tegoczesnych obrazów społecznych, Warszawa 1857.

DmochWsp - F.S. Dmochowski, Wspomnienia od 1806 do 1830 roku, oprac. Z. Libera, t. 1-2,Warszawa 1959.

DomL - I. Domeyko, Listy do Władysława Laskowicza, oprac. E.H. Nieciowa, Warszawa 1976.

DzBar - Dzienniki Ignacego Baranowskiego pisane w Lublinie przez rok 1815 i 1816, do druku przygotował B. Szyndler, Lublin 1995.

DzierzD - J. Dzierzkowski, Dla posagu. Powieść z życia towarzyskiego, t. 1-2, Lipsk 1847.

DzierzS - J. Dzierzkowski, Salon i ulica, Rzeszów 1989.

FrDz - A. Fredro, Wybór dziet, oprac. B. Zakrzewski, t. 1-2, Wrocław 1994.

GirtOp - K. Girtler, Opowiadania. Pamiętniki z lat 1832-1857, oprac. Z. Jabłoński, J. Staszek, Kraków 1971.

GodGr- C. Godebski, Grenadier-filozof, Wrocław 1953. 
GoszLis - Listy Seweryna Goszczyńskiego (1823-1875), zebrał i do druku przygotował S. Pigoń, Kraków 1937.

GrabWsp - A. Grabowski, Wspomnienia, oprac. S. Estreicher, t. 1-2, Kraków 1909.

GrabWsp - Wspomnienia Ambrożego Grabowskiego, wydał S. Estreicher, t. 1-2, Kraków 1909.

HoffKryst - K. Hoffmanowa, Krystyna, Lipsk 1852.

HoffPam - K. Hoffmanowa, Pamiętniki, Berlin 1849.

JanAu - J.N. Janowski, Notatki autobiograficzne 1803-1853, do druku przygotował M. Tyrowicz, Wrocław 1950.

KarP - F. Karpiński, Pamiętniki, przedm. P. Chmielowski, Warszawa 1898.

KarpHis - F. Karpiński, Historia mego wieku i ludzi, z którymi żyłem, Warszawa 1987.

KarpKor - Korespondencja Franciszka Karpińskiego z lat 1763-1825, red. K. Budzyk, T. Mikulski, S. Pigoń, Wrocław 1958.

KitPam - J. Kitowicz, Pamiętniki czyli historia polska, oprac. P. Matuszewska, Warszawa 1971.

KK - I. Krasicki, Komedie, oprac. M. Klimowicz, Warszawa 1956.

KKor - Korespondencja Ignacego Krasickiego, z papierów Ludwika Bernackiego wydali i oprac.

Z. Goliński, M. Klimowicz, R. Wołoszyński, red. T. Mikulski, t. 1-2, Wrocław 1958.

KniaźDram - F. D. Kniaźnin, Utwory dramatyczne, Warszawa 1958.

KolCzac - Księdza Hugona Kotłataja korrespondencya listowna z Tadeuszem Czackim wizytatorem nadzwyczajnym szkól, w guberniach wotyńskiéj, podolskiéj i kijowskiéj, przedsięwzięta w celu urzqdzenia instytutów naukowych i pomnożenia oświecenia publicznego $w$ trzech rzeczonych guberniach, t. 4, z rękopisu wydał F. Kojsiewicz, Kraków 1845.

KołLis - Listy Hugona Koltataja pisane z emigracyi w r. 1792, 1793 i 1794, Dwa tomy w jednym, zebrał Lucyan Siemieński, Poznań 1872.

KonfB - Konfederacja Barska. Korespondencyia między Stanisławem Augustem a Ksawerym Branickim łowczym koronnym w roku 1768, wydał dr L. Gumplowicz, Kraków 1872.

KonL - Listy Stanisława Konarskiego 1733-1771, oprac. J. Nowak-Dłużewski, Warszawa 1962.

KorAlc - Korespondencja dotyczqca wykreślenia się Jana Alcyaty z listy członków Towarzystwa Demokratycznego Polskiego, Paryż 1846.

KorFil - Korespondencja Filomatów (1817-1823), wybór i oprac. M. Zelińska, Warszawa 1989.

KorGrab - Korespondencja literacka Michała Grabowskiego, Wilno 1842.

KorKrak - Korespondencja z Krakowa, (Przedruk z numerów 28, 29, 30 i 31 dziennika „Polska”), Lwów 1848.

KorMic - Korespondencja Adama Mickiewicza, t. 1, Paryż 1871.

KorMod - Korespondencja Heleny Modrzejewskiej i Karola Chłapowskiego, t. 1, wybór i oprac. J. Got, J. Szczublewski, Warszawa 1965.

KorNar - Korespondencja Adama Naruszewicza 1762-1796, z papierów po Ludwiku Bernackim uzupełnił, opracował i wydał J. Platt, red. T. Mikulski, Wrocław 1959.

KorPot - Korespondencja Ignacego Potockiego w sprawach edukacyjnych (1774-1809), oprac. B. Michalik, Archiwum Dziejów Oświaty, t. VIII, red. K. Bartnicka, Wrocław 1978.

KorRadz - Korespondencja księcia Karola Stanisława Radziwiłła wojewody wileńskiego „Panie Kochanku” (1762-1790), ze zbiorów familijnych wydał K. Waliszewski, Kraków 1888.

KorSł - Korespondencja Juliusza Stowackiego to jest listy do matki i wszystkie inne, zebrał ks. K.J. Kantak, Mikołów-Warszawa 1910.

KorzDram - J. Korzeniowski, Dzieła wybrane, t. 7, Dramaty, Kraków 1954.

KorzDz - J. Korzeniowski, Dzieła, t. 10, Warszawa 1873.

KorzKol - J. Korzeniowski, Kollokacja, Kraków 1925.

KorzKom - J. Korzeniowski, Dzieła wybrane, t. 8, Komedie, Kraków 1954.

KorzOk - J. Korzeniowski, Okrężne, Komedia we dwóch aktach ze śpiewami i tańcami, Poznań 1898. 
KorzRep - J. Korzeniowski, Reputacja w miasteczku, komedia w 3 aktach, Warszawa 1857.

KorzSt - J. Korzeniowski, Stary maż, komedia we czterech aktach, Wilno 1844.

KorzWd -J. Korzeniowski, Młoda wdowa, Komedia we trzech aktach, Wilno 1847.

KośWsp - T. Kościuszko, Listy. Odezwy. Wspomnienia, zebrał H. Mościcki, Warszawa 1917.

KozW - A. Kozieradzki, Wspomnienia z lat szkolnych 1820-1831, Wrocław 1962.

KoźPam - K. Koźmian, Pamiętniki, wstęp oraz komentarz J. Willaume, t. 1-2, Wrocław 1971.

Kpt - Kapitan i dwie panny. Krakowskie pamiętniki z XIX wieku, oprac. I. Homola, B. Łopuszański, Kraków 1980.

KrasDel - Z. Krasiński, Listy do Delfiny Potockiej 1839-1843, przysposobił do druku A. Żółtowski, Poznań 1930.

KrasJar — Listy Zygmunta Krasińskiego od roku 1835 do 1844 pisane do Edwarda Jaroszewskiego, ogłosił M. Gorzkowski, Kraków 1871.

KrasLis - Z. Krasiński, Listy do plenipotenta i oficjalistów, zebrał, oprac. i wstępem poprzedził Z. Sudolski, Warszawa 1994.

KrasMal - Listy Zygmunta Krasińskiego do Stanisława Małachowskiego, Kraków 1885.

KrasPot — Listy Zygmunta Krasińskiego do Adama Potockiego, Warszawa 1922.

KrasSt - Z. Krasiński, Listy, t. 3, Lwów 1887.

KraszAn - J.I. Kraszewski, Pamiętnik anegdotyczny z czasów Stanisława Augusta Poniatowskiego, t. II, Warszawa 1906.

KraszDwa - J.I. Kraszewski, Dwa światy, Kraków 1967.

KraszDz - J.I. Kraszewski, Dzieci wieku, Kraków 1970.

KraszH - J.I. Kraszewski, Hołota, Powieść wspótczesna, Kraków 1986.

KraszJary - J.I. Kraszewski, Jaryna, przyg. do druku i przypisami opatrzył S. Burkot, Warszawa 1987.

KraszJer - J.I. Kraszewski, Jermoła. Obrazki wiejskie, Lwów 1873.

KraszLis - J.I.Kraszewski, Listy do rodziny 1820-1863, część I, W kraju, oprac. W. Danek, Kraków 1982.

KraszPam - J.I. Kraszewski, Pamiętniki, oprac. W. Danek, Kraków 1972.

KraszSt - J.I. Kraszewski, Dziecię Starego Miasta, oprac. W. Danek, Wrocław 1988.

KraszU - J.I. Kraszewski, Ulana, oprac. S. Tomaszewski, Wrocław 1988.

KuczGodz - K. Kucz, Godzina u dziennikarza, Krotochwila w jednym akcie ze śpiewkami, Warszawa 1859.

KuKas - Kufer Kasyldy czyli wspomnienia z lat dziewczęcych. Wybór z pamiętników XVIIIXIX w. dokonały D. Stępniewska i B. Walczyna, Warszawa 1953.

LelNie - Nieznane listy Joachima Lelewela z lat 1831-1846, wydała J. Berger-Mayerowa, Katowice 1961.

LenarKor - J.I. Kraszewski, T. Lenartowicz, Korespondencja, Wrocław 1963.

LewPam - K. Lewandowski, Pamiętniki wychodźca polskiego, Warszawa 1977.

LisDuń - X.E. Duński, Listy 1848-1856, wydali i wstępem opatrzyli A. Begey i J. Komenda, Turyn 1915.

LisJak - Listy Wojciecha Jakubowskiego do Jana Klemensa Branickiego W. Hetmana Koronnego z lat 1758-1771, przypisami objaśnił i dodatkami uzupełnił J. Bartoszewicz, Warszawa 1882.

LisKn - W.M. Kozłowski, Listy Kniaziewicza do Dąbrowskiego i Kościuszki, Lwów 1899.

LisKos - Listy Katarzyny z Potockich Kossakowskiéj kasztelanowéj Kamieńskiej 1754-1800, wydał K. Waliszewski, Poznań 1883.

LisLen - Listy Teofila Lenartowicza do Ewarysta Estkowskiego (1850-1856), Poznań 1922.

LisPol - Listy z ziemi naszej, Korespondencja Wincentego Pola z lat 1826-1872, zebrał, oprac. i wstępem opatrzył Z. Sudolski, Warszawa 2004. 
LisRS - W kregu bliskich poety. Listy rodziny Juliusza Słowackiego, oprac. S. Makowski i Z. Sudolski, red. E. Sawrynowicz, Warszawa 1960.

LM - Listy miłosne dawnych Polaków, wybór, wstęp i komentarz M. Misiorny, Kraków 1971.

LubRep - S. Lubomirski, Pod władza księcia Repnina. Ułamki pamiętników i dzienników historycznych (1764-1768), oprac. i wstępem poprzedził J. Łojek, Warszawa 1971.

LosHis - W. Łoziński, Historja siwego włosa, Poznań 1871.

LozCh - W. Łoziński, Szlachcic chodaczkowy. Powieść cz. I-III, Warszawa 1909.

LozDw - W. Łoziński, Zaklęty dwór, oprac. dr A. Bar, Kraków 1926.

LozG - W. Łoziński, Dwunasty gość, Lwów 1927.

LozNoc - W. Łoziński, Dwie noce, Kraków 1953.

MagBac - D. Magnuszewski, Posiedzenie Bacciarellego malarza, przygotował do druku K. Bartoszyński, Poznań 1968.

MajerKron - K. Majeranowski, Kronika 40 dni Krakowa 1848 roku, poprzedzona prologiem dziejów Polski i Krakowa w dziesięciu obrazach i epilogiem wypadków po dniu 26 kwietnia, Kraków 1848.

MicKon - Listy śp. Adama Mickiewicza do pani Konstancyi, Poznań 1863.

MicPam - W. Mickiewicz, Pamiętniki, t. 1, 1838-1861, Kraków 1920.

MochLis - Listy Maurycego Mochnackiego i brata jego Kamila wyszłych z wojskiem polskiem do Francji w roku 1831, Poznań 1863.

MorDiar - T.K. Morawska, Diariusz podróży 1773-1774, oprac. B. Rok, Wrocław 2002.

MorLis - S. Morawski, Z wielkiej samotni. Listy do Heleny i Franciszka Malewskich, oprac. Z. Sudowska, Warszawa 1981.

NarLis - A. S. Naruszewicz, Wybór poezyj z dołaczeniem kilku pism prozq oraz listów, Warszawa 1882.

NiemDom - J.U. Niemcewicz, Pan Nowina czyli dom pocztowy, komedia oryginalna we trzech aktach, Warszawa 1815.

NiemPod - J. U. Niemcewicz, Podejrzliwi, Oryginalna komedia wierszem $w$ pięciu aktach, Warszawa 1831.

NiemPowr - J. U. Niemcewicz, Powrót posła, komedia we trzech aktach, Kraków 1927.

OIPam1 - N. Olizar, Pamiętniki Oryginała, t. 1, Lipsk 1853.

OpDz - Opowieści dziewczęce. Ustępy z pamiętników młodych panien (1776-1866), oprac. S. Wasylewski, Kraków 1957.

OrWęd - L. Orpiszewski, Wędrówka po Wielko-Polsce i Mazowszu. Powieść wzięta z ostatnich wypadków, Paryż 1838.

OsP - J. Osipowska, Pierścionek, t. 1-2, Warszawa 1842.

PamFel1 - Pamiętniki z życia Ewy Felińskiej, t. 1, Wilno 1859.

PamGaj-Pamiętniki Franciszka z Błociszewa Gajewskiego pułkownika wojsk polskich(1802-1831), do druku przysposobione przez S. Karwowskiego, t. 2, Poznań [b.r.w.].

PamGal - Pamiętniki spiskowców i więźniów galicyjskich w latach 1832-1846, oprac. K. Lewicki, Wrocław 1954.

PamGąs - Pamiętniki pułkownika Józefa Dominika Gąsianowskiego z r. 1793-1794, Lwów 1861.

PamKasz - Pamiętniki Marcina Matuszewicza kasztelana brzeskiego-litewskiego. 1714-1765, wydał A. Pawiński, t. 4, Warszawa 1876.

PamL - Pamiętniki krakowskiej rodziny Louisów (1831-1869), oprac. J. Zathey, Kraków 1962.

PamOch - Pamiętniki Jana Duklana Ochockiego z pozostatych po nim rękopisów, przepisane i wydane przez J. I. Kraszewskiego, Wilno 1857.

PamOśm1 - Pamiętniki Jana Kilińskiego, szewca, a razem pułkownika 20. Regimentu, [w:] Pamiętniki z ośmnastego wieku, t. 1, Poznań 1860.

PamOśm2 - Pamiętniki Filipa Lichockiego o powstaniu w Krakowie 1794, [w:] Pamiętniki z ośmnastego wieku, Poznań 1862. 
PamOśm5 - Drugi rozbiór Polski z pamiętników Sieversa, [w:] Pamiętniki z ośmnastego wieku, t. 5, Poznań 1865.

PamRadz - Pamiętnik o księciu Karolu Radziwille spisany podtug archiwum nieświezkiego, Rękopis udzielony do druku ze zbiorów Wiktora hr. Baworowskiego, Lwów 1864.

PamUı - A. Goczałkowski, Pamiętniki ułana, Lwów 1855.

PamWit - M. Witkowski, Pamiętniki prostego żolnierza z lat 1812-1816, Źródła Historyczno-Literackie, t. II, Pamiętniki z lat 1792-1849, oprac. R. Grabałowski, Wrocław 1961.

PamWoj - Biblioteka pamiętników i podróży po dawnej Polsce wydawana przez J. Kraszewskiego, t. 6, Pamiętniki wojenne 1792-1812, Drezno 1871.

PamWoź - Pamiętniki woźnego cenzury, Warszawa 1831.

PawEd - K. Pawłowski, Edward czyli skutki niedoświadczenia. Romans oryginalny, Warszawa 1827.

ProcPil - R. S. Pilsztynowa, Proceder podróży i życia mego awantur, oprac. R. Pollak, Kraków 1957.

PrusMor - J. Prusiecka, Powieści moralne, Warszawa 1843.

PuzPam - G. Puzynina, $W$ Wilnie $i w$ dworach litewskich, Pamiętnik z lat 1815-1843, Kraków 1990.

RaRa - Ł. Rautenstranchowa, Ragawa czyli płochość, t. 1, Warszawa 1830.

RusWar - K.R. Rusiecki, Mate tajemnice Warszawy. Zarysy obyczajowe oryginalne, t. 2-4, Warszawa 1844.

RzewKron - L. Rzewuski, Kronika podhorecka, Kraków 1860.

RzewLis - H. Rzewuski, Listopad, romans historyczny z drugiej połowy XVIII w., t. 1-2, Wilno 1862.

RzewMich - H. Rzewuski, Pamiętniki Barttomieja Michałowskiego, Petersburg 1856.

RzewPam - H. Rzewuski, Pamiatki Soplicy, Warszawa 1983.

SchSt - Na schyłku dni Rzeczypospolitej, Kartki z pamiętnika Michała Starzeńskiego (1757-1795), wydał H. Mościcki, Warszawa 1914.

SkarbDod - Fryderyk Skarbek, Życie i przypadki Faustyna Feliksa na Dodoszach Dodosińskiego, Warszawa 1874.

SkarbPam - Fryderyk Skarbek, Pamiętniki, Poznań 1878.

SkarbPan - Fryderyk Skarbek, Pan Antoni, Wrocław 1840.

SkarbPow - Fryderyk Skarbek, Powiastki polskie, Poznań 1861.

SkarbSt - Fryderyk Skarbek, Pan starosta, Warszawa 1874.

SkarbTar - Fryderyk Skarbek, Tarto, Gródek 1890.

SkarSegl - Franciszek Skarbek, Pamiętniki Seglasa, Warszawa 1959.

SzymLis - J. Szymanowski, Listy do starościny wyszogrodzkiej, oprac. F. Korwin-Szymanowski, Warszawa 1973.

ŚniaLis - Listy Jana Śniadeckiego w sprawach publicznych od roku 1788 do 1800, wstęp i przypiski J.I. Kraszewskiego, Poznań 1878.

TańDzien - K. Tańska, Dziennik Franciszki Krasińskiej w ostatnich latach panowania Augusta III pisany, Kraków 1929.

TańLis - K. Tańska, Listy Elżbiety Rzeczyckiej, Kraków 1927.

TKor - Tajna korespondencja z Warszawy do Ignacego Potockiego 1792-1794, oprac. M. Rymszyna i A. Zahorski, Warszawa 1961.

TremNie - S. Trembecki, Nieznane listy, z rękopisów Biblioteki Zamojskich wydał, wstępem i objaśnieniami opatrzył W.T. Baranowski, Warszawa 1914.

TrenLis - Listy Stanisława Trentowskiego (1836-1869), zebrał i do druku przygotował S. Pigoń, Kraków 1937.

WilkWsp - P. Wilkońska, Moje wspomnienia o życiu towarzyskim w Warszawie, Warszawa 1959. 
WirMal - M. z Czartoryskich Wirtemberska, Malwina czyli domyślność serca, Kraków 2002.

WójDw - K.W. Wójcicki, Dworek i pałac, Warszawa 1856.

WójK - K.W. Wójcicki, Kawa literacka, Warszawa 1873.

WójN - K.W. Wójcicki, Niewiasta polska w początkach naszego stulecia (1800-1830), Warszawa 1875.

WójP - K.W. Wójcicki, Pamiętniki dziecka Warszawy, Kraków 1909.

WójSp - K.W. Wójcicki, Społeczność Warszawy w poczq̨tkach naszego stulecia (1800-1830), Warszawa 1877.

WybDr - J. Wybicki, Utwory dramatyczne, oprac. R. Kaleta, Warszawa 1963.

WybŻ - J. Wybicki, Życie moje oraz wspomnienia o Andrzeju i Konstancji Zamoyskich, z rękopisów wydał i objaśnił A.M. Skałkowski, Kraków 1927.

WysLis - H. Wysocki, Przemówity stare listy, Kraków 1986.

ZabDz1 - F. Zabłocki, Dzieła, t. 1, Warszawa 1877.

ZabF - F. Zabłocki, Fircyk w zalotach, oprac. J. Pawłowiczowa, Wrocław 1973.

ZałWsp - J. Załuski, Wspomnienia, oprac. A. Palarczykowa, Kraków 1976.

ZamT - E. Tarsza, Zamieć w stepach. Opowiadanie obywatela z polskiej Ukrainy, w pierwszych latach XIX w., Petersburg 1862.

ZielWsp -J. F. Zieliński, Wspomnienia z tułactwa, wyd. E. Wróblewska, Warszawa 1989.

ŻmLis1 - N. Żmichowska, Listy, t. 1, W kręgu najbliższych, do druku przygotowała i komentarzami opatrzyła M. Romankówna, Wrocław 1957.

ŻmLis2 - N. Żmichowska, Listy, t. 2, Rozdroża, do druku przygotowała i komentarzami opatrzyła M. Romankówna, Wrocław 1960.

ŻmPow - N. Żmichowska, Wybór powieści, t. 1-2, Warszawa 1953.

\section{OPRACOWANIA}

Awdiejew A., Pragmatyczne podstawy interpretacji wypowiedzeń, Kraków 1987.

Awdiejew A., Strategie konwersacyjne (próba typologii), „Socjolingwistyka” 1991, t. 11.

Awdiejew A., Habrajska G., Wprowadzenie do gramatyki komunikacyjnej, t. 1, Łask 2004.

Bajerowa I., Niektóre treści i metody socjolingwistyczne $w$ historii języka, „Biuletyn Polskiego Towarzystwa Językoznawczego" 1972, t. XXX.

Bajerowa I., Polski język ogólny XIX w. Stan i ewolucja, t. 1-3, Katowice 1986.

Bartnicka B., Sposoby zwracania się do rozmówcy w „Pamiatkach Soplicy” Henryka Rzewuskiego (Szkic z pragmatyki historycznej), „Poradnik Językowy” 1989, z. 5.

Bartmiński J., Wokót Lordowskiej koncepcji formuly, [w:] Pojęcie derywacji w lingwistyce, red. J. Bartmiński, Lublin 1981.

Betlejczyk F., O języku towarzyskim, Kraków 1862.

Bogucka M., Staropolskie obyczaje w XVI-XVII wieku, Warszawa 1994.

Bokszański Z., Piotrowski A., Ziółkowski M., Socjologia języka, Warszawa 1977.

Boniecka B., Lingwistyka tekstu. Teoria i praktyka, Lublin 1999.

Borawski S., Spontaniczność i konwencja w etykietalnych formułach adresowych (na materiale listów Z. Miłkowskiego do J. Łukaszewskiego), [w:] Gatunki mowy i ich ewolucja, t. 2, Katowice 2002.

Brajerski T., Podstawowe honorativa we wczesnych komediach Aleksandra Fredry, „Roczniki Humanistyczne" 1995, z. 6: Językoznawstwo, t. XLIII.

Brown R., Gilman A., The Pronouns of Power and Solidarity, [w:] Style in Language, ed. T. Sebeok, Boston 1960. 
Brown P., Levinson S. C., Politeness: Some Universals in Language Usage. Studies in interactional sociolinguistics, Cambridge 1987.

Brückner A., Ty - Wy - Pan. Kartka z dziejów próżności ludzkiej, Kraków 1916.

Brückner A., Encyklopedia staropolska, t. 1-2, Warszawa 1939.

Brückner A., Stownik etymologiczny języka polskiego, Warszawa 1989.

Bula D., Nawacka J., Próba klasyfikacji aktów mowy, „Socjolingwistyka” 1983, t. 5.

Bula D., O sposobach zwracania się do rozmówcy, „Prace Naukowe Uniwersytetu Śląskiego w Katowicach" 1985, Prace Językoznawcze 10.

Bystroń J. S., Dzieje obyczajów w dawnej Polsce. Wiek XVI-XVIII, t. 1-2, Warszawa 1976.

Chmielowiec M., Z życia wyrazów. Aśćka i inne tytuly staropolskie (Przykład lekcji w klasie V gimnazjalnej), „Język Polski” 1924, nr 9.

Chojnacki M., Wyrażenia grzecznościowe w „Panu Tadeuszu”, „Poznańskie Studia Polonistyczne” 1996, nr 3.

Cybulski M., Elementy chrześcijańskie w staropolskim obyczaju językowym, [w:] Biblia a kultura Europy, red. M. Kamińska, E. Małek, Łódź 1992.

Cybulski M., Pan i sługa. Niektóre spoleczne uwarunkowania zmian w polskich obyczajach językowych, [w:] Uwarunkowania i przyczyny zmian językowych. Zbiór studiów, red. E. Wrocławska, Warszawa 1994.

Cybulski M., O staropolskich i średniopolskich zwyczajowych określeniach nadawcy wypowiedzi, Studia Historycznojęzykowe I, red. M. Kucała, Z. Krążyńska, Kraków 1994.

Cybulski M, Polskie formuly powitalne od XVI do połowy XVIII wieku, „Prace Naukowe Uniwersytetu Śląskiego" 1996, Prace Językoznawcze 24.

Cybulski M., Polskie formuly toastu do XVIII w., [w:] Kultura ubóstwa - kultura przetrwania, red. D. Zalewska, Wrocław 1996.

Cybulski M., Polskie formy rozkazu i zakazu do połowy XVIII w., [w:] Regulacyjna funkcja tekstów, red. K. Michalewski, Łódź 2000.

Cybulski M., Staropolskie formy podziękowań, [w:] Od średniowiecza ku wspótczesności. Prace ofiarowane Jerzemu Starnawskiemu w pięćdziesięciolecie doktoratu, red. J. Okoń, Łódź 2000.

Cybulski M., Obyczaje językowe dawnych Polaków. Formuly werbalne w dobie średniopolskiej, Łódź 2003.

Cybulski M., Skrócenia $w$ dawnych polskich formach adresatywnych, „Rozprawy Komisji Językowej Łódzkiego Towarzystwa Naukowego" 2004, R. XLIX.

Cybulski M., Z historii polskich form adresatywnych. „,Waszeć” w XVII i XVIII wieku, [w:] Spotkanie. Ksiega Jubileuszowa dla Profesora Aleksandra Wilkonia, red. M. Kita, B. Witosz, Katowice 2005.

Cybulski M., O ograniczeniu fleksji w formułach polskiej etykiety językowej, „Rozprawy Komisji Językowej Łódzkiego Towarzystwa Naukowego" 2010, R. LV.

Dąbrowska A., Formy zwracania się do innych w niektórych językach europejskich, „Acta Universitatis Wratislaviensis" 1983, Studia Linguistica 8.

Dąbrowska A., Sposoby kończenia rozmowy w sytuacji oficjalnej, [w:] Język a kultura, t. 6, Polska etykieta językowa, red. J. Anusiewicz, M. Marcjanik, Wrocław 1992.

Długosz-Kurczabowa K., Stownik etymologiczny języka polskiego, Warszawa 2006.

Dunaj B., Odmiana oficjalna i nieoficjalna języka mówionego, „Zeszyty Naukowe Uniwersytetu Jagiellońskiego" 1981, Prace Językoznawcze 70.

Dunaj B., Sytuacja komunikacyjna a zróżnicowanie polszczyzny mówionej, „Język Polski” 1985, R. LXV.

Dykiel D., Formy adresatywne w „Wydwornym polityku M. Guthëtera-Dobrackiego”, „Rozprawy Komisji Językowej Wrocławskiego Towarzystwa Naukowego" 1989, t. 16.

Dyskurs jako struktura i proces, red. A. van Dijk, przeł. G. Grochowski, Warszawa 2001.

Furdal A., Językoznawstwo otwarte, Wrocław 2000. 
Galasiński D., Czy przestrzeganie regut konwersacyjnych zawsze sprzyja udatności aktu mowy?, „Polonica” 1994, nr 16.

Gałczyńska A., Niedefinicyjne funkcje performatywu przepraszam, „Poradnik Językowy” 2002, z. 4.

Gawęda E., Urban K., Zabierowska K., O pewnym typie illokucji - toasty, „Prace Naukowe Uniwersytetu Śląskiego" 1982, Socjolingwistyka 4.

Goffman E., Człowiek w teatrze życia codziennego, Warszawa 2000.

Gołachowska E., Formy grzecznościowe szlachty podlaskiej i grodzieńskiej. Zarys problematyki, „Acta Baltico-Slavica” 2007, t. 31.

Góralski Z., Urzędy i godności w dawnej Polsce, Warszawa 1983.

Grabias S., Język w zachowaniach społecznych, Lublin 1994.

Gradzik-Jedynak B., Obyczaje polskie drugiej połowy XVIII i pierwszej połowy XIX wieku. Antologia, Lublin 1981.

Grodziński E., Rola formuł grzecznościowych w językach współczesnych, „Poradnik Językowy” 1977, z. 7.

Grodziński E., Niezwykłe właściwości zwykłych czasowników, „Poradnik Językowy” 1978, z. 2.

Grodziński E., Wypowiedzi performatywne. Z aktualnych zagadnień filozofii języka, Wrocław 1980.

Grodziński E., Z zagadnień wspótczesnej filozofii języka. Teoria performatywów i jej krytycy, „Przegląd Humanistyczny" 1980, nr 1.

Grodziński E., O czasownikach perlokucyjnych, „Poradnik Językowy” 1981, z. 4

Grosse J., Pan, ty, czy wy, Kraków 1906.

Grybosiowa A., Formy ty i pan w kontaktach społecznych, „Poradnik Językowy” 1990, z. 2.

Grybosiowa A., Przyczyny zmian w polskim systemie adresatywnym, [w:] Język w mieście. Problemy kultury i poprawności, red. K. Michalewski, „Acta Universitatis Lodziensis” 1998, Folia Linguistica 37.

Grzegorczykowa R., Językowe wyktadniki intencji wypowiedzi, „Biuletyn Polskiego Towarzystwa Językoznawczego" 1989, t. XLII42.

Grzegorczykowa R., Wprowadzenie do semantyki językoznawczej, Warszawa 2001.

Habrajska G., Struktura życzeń światecznych, „Poradnik Językowy” 1993, z. 7.

Handke K., Socjologia języka, Warszawa 2008.

Hautepierre J., Sztuka pisania listów czyli dzieto elementarne podaiqce sposób dobrego uktadania listów, z francuzkiego na polski język przełożone przez Wojciecha Sitkiewicza, Wrocław 1822.

Huszcza R., O gramatyce grzeczności, „Pamiętnik Literacki” 1980, z. 71.

Huszcza R., Honoryfikatywność. Gramatyka, pragmatyka, typologia, Warszawa 1996.

Kaczyński Z., Miejsce pozdrowień wśród wypowiedzi językowych, „Acta Universitatis Wratislaviensis" 1983, Folia Linguistica 8.

Kalisz R., Pragmatyka językowa, Gdańsk 1993.

Kałkowska A., Struktura składniowa listu, Warszawa 1982.

Kamyczek J., Grzeczność na co dzień, Warszawa 1974.

Kita M., O możliwościach badań nad przemianami rozmowy (źródła do badań), [w:] Gatunki mowy i ich ewolucja, red. D. Ostaszewska, Katowice 2000.

Klemensiewicz Z., Pan i obywatel, „Język Polski” 1946, R. XXVI.

Kominek A., Funkcje grzecznościowe proszę we wspótczesnej polszczyźnie, [w:] Język a kultura, t. 6, Polska etykieta językowa, red. J. Anusiewicz, M. Marcjanik, Wrocław 1992.

Korzeniowski M., Nowy sekretarz powszechny: ksiażka podręczna dla osób każdego stanu zawierajq̨ca: wybór wzorowych listów we wszystkich stosunkach i okolicznościach potocznego życia, wybranych z dziet najnowszych autorów, wraz z uwagami o listach, tudzież o sposobie pisania samemu w różnych materyach; Wzory przedstawień do władz rzadowych, wekslów, obligów, kontraktów, cessyi, testamentów, rozmaitych zapisów, zaświadczeń, wszelkich aktów urzędowych i. t. p. z dołaczeniem krótkich obiaśnień nad temiż, Wrocław 1843. 
Korzeniowski M., Pisarz listów powszechny: wybór wzorowych listów we wszelkich stosunkach i okolicznościach potocznego życia: wzory przedstawień do władz rzqdowych, wekslów, obligów, kontraktów, cessyi, testamentów, rozmaitych zapisów, zaświadczeń, wszelkich aktów urzędowych i.t.p., Wrocław 1847

Korzeniowski M., Wybór wzorowych listów we wszelkich stosunkach i okolicznościach potocznego życia. Wzory do władz rzadowych, wekslów, obligów, kontraktów, cessyi, testamentów, rozmaitych zapisów, zaświadczeń, wszelkich aktów urzędowych i.t.p. z dołączeniem krótkich obiaśnień nad temiż, Wrocław 1847.

Kuchowicz Z., Obyczaje staropolskie XVII-XVIII wieku, Łódź 1975.

Kuryłowicz J., Podstawowe kategorie morfologiczne, „Biuletyn Polskiego Towarzystwa Językoznawczego" 1971, t. XLIX.

Labocha J., Sposoby wyrażania żadania we wspótczesnej polszczyźnie mówionej, cz. 1, „Polonica” 1985, nr 11.

Labocha J., Sposoby wyrażania żadania we wspótczesnej polszczyźnie mówionej, cz. 2, „Polonica” 1986, $\mathrm{nr} 12$.

Lakoff R., The Logic of Politeness! or, Minding Your P's and q's, [w:] Papers from the Ninth regional Meeting Chicago Linguistic Society, Chicago 1973.

Lalewicz J., Język, wypowiedź, akt mówienia, „Studia Semiotyczne” 1972, t. III.

Lalewicz J., Retoryka kategorii osobowych, [w:] Tekst i zdanie. Zbiór studiów, red. T. Dobrzyńska, E. Janus, Wrocław 1983.

Leech G., Priciples of Pragmatics, London 1983.

Leitgeber S., O życiu towarzyskim w Wielkopolsce w XIX i XX wieku, Poznań 2001.

Łaziński M., O panach i paniach. Polskie rzeczowniki tytularne i ich asymetria rodzajowo-ptciowa, Warszawa 2006.

Łoziński W., Życie polskie w dawnych wiekach, Kraków 1974.

Łoś J., Od ty do pan, „Język Polski” 1916, R. III.

Marcjanik M., Polskie czasowniki adresatywne. Pragmatyka, semantyka, składnia, Kielce 1987.

Marcjanik M., Normy regulujace językowe zachowania grzecznościowe, „Przegląd Humanistyczny” $1990, \mathrm{nr} 7$.

Marcjanik M., Miejsce etykiety językowej wśród wartości, Uwagi ogólne, [w:] Język a kultura, t. 3, Wartości w języku i tekście, red. J. Puzynina, J. Anusiewicz, Wrocław 1991, s. 61-65.

Marcjanik M., Typologia polskich wyrażeń językowych o funkcji grzecznościowej, [w:] Język a kultura, t. 6, Polska etykieta językowa, red. J. Anusiewicz, M. Marcjanik, Wrocław 1992.

Marcjanik M., Wspótczesne polskie toasty - przejawem pauperyzacji życia towarzyskiego, [w:] Język a kultura, t. 5, Potoczność w życiu i kulturze, red. J. Anusiewicz, M. Marcjanik, Wrocław 1992.

Marcjanik M., Etykieta językowa, [w:] Encyklopedia kultury polskiej XX w., t. 2, Współczesny język polski, red. J. Bartmiński, Wrocław 1993.

Marcjanik M., Struktura komunikacyjna podziękowania, „Socjolingwistyka” 1994, t. 14.

Marcjanik M., Polska grzeczność językowa, Kielce 2000.

Marcjanik M., Etykieta językowa, [w:] Współczesny język polski, Lublin 2001.

Marcjanik M., W kręu grzeczności. Wybór prac z zakresu polskiej etykiety językowej, Kielce 2001.

Marcjanik M., Prawienie grzeczności a obmawianie. Językowy obraz osoby komplementowanej i obmawianej, [w:] Język a kultura, t. 17, Życzliwość i agresja w języku i kulturze, red. A. Dąbrowska, A. Nowakowska, Wrocław 2005.

Marcjanik M., Grzeczność w komunikacji językowej, Warszawa 2007.

Markiewicz H., Główne problemy wiedzy o literaturze, Kraków 1980.

Masłowska E., Proszę, dziękuje, przepraszam, [w:] Język a kultura t. 6, Polska etykieta językowa, red. J. Anusiewicz, M. Marcjanik, Wrocław 1992. 
Matuszewska P., Listowniki polskie. Stan i perspektywy badań, „Pamiętnik Literacki” 1982, z. 3/4.

Michalewski K., Oponowanie cudzym wypowiedziom, „Rozprawy Komisji Językowej Łódzkiego Towarzystwa Naukowego" 2000, R. XLV.

Miodek J., Jeszcze o sposobach zwracania się do drugich, „Język Polski” 1980, R. LX.

Miozga E., Osiemnastowieczne listowniki. Teoria i praktyka, Katowice 2000.

Moszyński L., Biblijne pozdrowienia w przekładach słowiańskich, [w:] Inspiracje chrześcijańskie w kulturze Europy, red. E. Woźniak, Łódź 2000.

Mroczek M., Tytulatura w korespondencji staropolskiej jako problem stosunku między nadawca a odbiorca, „Pamiętnik Literacki” 1978, z. 69.

Nitsch K., Pan, ty czy wy?, „Poradnik Językowy” 1907.

Obyczaje w Polsce od średniowiecza do czasów wspótczesnych, red. A. Chwalba, Warszawa 2004.

Okopień-Sławińska A., Jak formy osobowe graja w teatrze mowy, [w:] Tekst i fabuła. Studia, red. Cz. Niedzielski, J. Sławiński, Wrocław 1979.

Ożóg K., Powitania i pożegnania w języku mówionym mieszkańców Krakowa, „Język Polski” 1980, t. 60 .

Ożóg K., Podziękowania w polszczyźnie mówionej, „Język Polski” 1982, R. LXII.

Ożóg K., Przeproszenia w dzisiejszej polszczyźnie, „Język Polski” 1985, R. LXV.

Ożóg K., Zwroty grzecznościowe współczesnej polszczyzny mówionej (na materiale języka mówionego mieszkańców Krakowa), Kraków 1990.

Ożóg K., Jednostki otwierajace i zamykajace replikę w dialogu, [w:] Studia nad polszczyznq mówiona Krakowa, t. 3, red. B. Dunaj, K. Ożóg, Kraków 1991.

Ożóg K., O niektórych aspektach semantyki zwrotów grzecznościowych, [w:] Język a kultura, t. 6, Polska etykieta językowa, red. J. Anusiewicz, M. Marcjanik, Wrocław 1992.

Peisert M., Etykieta językowa i jej wyznaczniki, [w:] Język a kultura, t. 1, Podstawowe pojęcia i problemy, red. J. Anusiewicz, J. Bartmiński, Wrocław 1991.

Pisarkowa K., Pragmatyczne spojrzenie na akt mowy, „Polonica” 1976, t. II.

Pisarkowa K., Jak się tytułujemy i zwracamy do drugich, „Język Polski” 1979, R. LIX.

Rachwał M., Formy adresatywne w mowach staropolskich, „Poradnik Językowy” 1987, z. 7.

Rachwał M., „Panie Wokulski”, czyli o pewnym typie form adresatywnych w ,Lalce” Bolestawa Prusa, „Prace Językoznawcze” 1991, nr 6.

Rachwał M., O przyczynach zmian systemu adresatywnego języka polskiego $w$ XIX w., [w:] Język a kultura, t. 6, Polska etykieta językowa, red. J. Anusiewicz, M. Marcjanik, Wrocław 1992.

Rachwał M., Grzecznościowe akty mowy w korespondencji W. Orkana z matka, „Annales Academiae Paedagogicae Cracoviensis" 2002, Studia Linguistica I.

Rzepka R., Walczak B., Socjolekt szlachecki XVII wieku (Próba ogólnej charakterystyki), [w:] Barok w polskiej kulturze i języku. Materiaty z konferencji naukowej 25-29 sierpnia 1987 w Krakowie, red. M. Stępień, S. Urbańczyk, Warszawa 1987.

Safarewiczowa H., Tytuty grzecznościowe w „Panu Tadeuszu”, [w:] W stużbie nauce i szkole. Księga pamiatkowa poświęcona prof. doktorowi Z. Klemensiewiczowi, Warszawa 1970.

Searle J.R., Czynności mowy: rozważania z filozofi języka, tłum. B. Chwedeńczuk, Warszawa 1987.

Sikora K., Jak pan zawędrowat na wieś, „Język Polski” 1993, R. LXXIII.

Skwarczyńska S., Teoria listu, Białystok 2006.

Stone G., W sprawie charakterystyki gramatycznej wyrazów pan, pani, państwo, „Studia z Filologii Polskiej i Słowiańskiej" 1981, t. 20.

Stone G., Honorific Pronominal Address in Polish Before 1600, „Oxford Slavonic Papers, New Series" 1984, vol. XVII.

Stone G., Polish Pronominal Address in the Seventeenth Century, „Oxford Slavonic Papers, New Series" 1985 , t. XVII.

Stone G., Formy adresatywne języka polskiego w osiemnastym wieku, „Język Polski” 1989, R. LXIX. 
Szczypka K., Formy adresatywne w „Polskiej Komedii Rybaltowskiej”, „Rozprawy Komisji Językowej Wrocławskiego Towarzystwa Naukowego" 1989, t. XVI.

Szymański S., Wzory biletow, listow i memoryałow w rożnych materyach z przydatkiem uwag w powszechności o stylu listownym przypisków względem szczegulnych listów gatunkow i drobnych przestrog względem formalności w pisaniu, t. 1, Warszawa 1784.

Tomiczek E., System adresatywny wspótczesnego języka polskiego i niemieckiego. Socjolingwistyczne studium konfrontatywne, Wrocław 1983.

Tomiczek E., Grzeczność w języku, [w:] Bilingwizm, bikulturyzm, implikacje dydaktyczne, red. F. Grucza, Warszawa 1989.

Tomiczek E., Z badań nad istota grzeczności językowej, [w:] Język a kultura, t. 6, Polska etykieta językowa, red. J. Anusiewicz, M. Marcjanik, Wrocław 1992.

Tyszyński A., TY, WY, PAN. Czyli o znaczeniu osobistości w języku polskim. Uwaga do psycho-lingwistyki, „Biblioteka Warszawska” 1874, t. 2.

Umińska-Tytoń E., Formuły grzecznościowe w XVIII-wiecznych diariuszach, „Rozprawy Komisji Językowej Łódzkiego Towarzystwa Naukowego" 1992, R. XXXVII.

Umińska-Tytoń E., Co wiemy o zasadach salonowej konwersacji? (Na podstawie pamiętników i kodeksów obyczajowych z drugiej połowy XIX w.), [w:] Między kulturq ,niskq" a ,wysokq". Zjawiska językowe, literackie, kulturowe, red. M. Korytkowska, Z. Darasz, G. Minczew, Łódź 2001.

Umińska-Tytoń E., Komplementy czyli piękne stówka, [w:] Piękno duchowe, piękno materialne, A. Tomecka-Mirek, Łódź 2004.

Umińska-Tytoń E., Wzorce niewerbalnych zachowań komunikacyjnych w XIX wieku (na podstawie kodeksów obyczajowych), „Studia Językoznawcze Uniwersytetu Szczecińskiego” 2009, t. 8, Synchroniczne i diachroniczne aspekty badań polszczyzny.

Umińska-Tytoń E., Polszczyzna dziewiętnastowiecznych salonów, Łódź 2011.

Urbańczyk S., Periodyzacja dziejów polskiego języka literackiego, [w:] Prace z dziejów języka polskiego, Wrocław 1979.

Warchała J., Pragmatyka dialogu potocznego, „Socjolingwistyka” 1991, t. XI.

Waszakowa J., Etykieta językowa w gwarach polskich na przykładzie trzech zbiorów tekstów gwarowych, „Socjolingwistyka” 1992, t. 12/13.

Wierzbicka A., Genry mowy, [w:] Tekst i zdanie. Zbiór studiów, red. T. Dobrzyńska, E. Janus, Wrocław 1983.

Wierzbicka A., Akty mowy, [w:] Semiotyka i struktura tekstu, red. M.R. Mayenowa, Wrocław 1973.

Wierzbicka A., Genry mowy, [w:] Tekst i zdanie. Zbiór studiów, red. T. Dobrzyńska, E. Janus, Wrocław 1983.

A. Wilkoń, Język mówiony a pisany, „Socjolingwistyka” 1982, t. 4.

Wiśniewska H., Tytulatura Sebastiana Klonowica (1545-1602), „Język Polski” 1982, R. LXII.

Wiśniewska H., Kultura językowa Katarzyny Zamoyskiej w świetle jej listów do męża, „Pamiętnik Literacki” 1990, z. 81.

Wojtak M., O funkcjonowaniu form rozkaźnika jako wykładników honoryfikatywności w tekstach wybranych dramatów, „Annales UMCS” 1988, Sectio F, Philologiae 6.

Wojtak M., Grzeczność po staropolsku w świetle „Pamiętników” Jana Chryzostoma Paska, „Poradnik Językowy" 1989, z. 8.

Wojtak M., Staropolska etykieta językowa jako obraz relacji międzyludzkich (wybrane zagadnienia), [w:] Przeszłość w językowym obrazie świata, red. A. Pajdzińska, P. Krzyżanowski, Lublin 1999.

Wojtak M., Wybrane elementy staropolskiej etykiety językowej, [w:] Język a kultura, t. 6, Polska etykieta językowa, red. J. Anusiewicz, M. Marcjanik, Wrocław 1992. 
Wojtak M., „O polityce w słowiech”. Formy adresatywne w XVIII wieku, „Język Polski” 1996, R. LXXVI.

Wojtak M., Staropolska etykieta językowa jako obraz relacji międzyludzkich (Wybrane zagadnienia), [w:] Przeszłość w językowym obrazie świata, red. A. Pajdzińska, P. Krzyżanowski, Lublin 1999.

Wojtasiewicz O., O performatywnym użyciu wyrażeń, „Poradnik Językowy” 1975.

Wychowaniec dziewiętnastego wieku czyli przepisy przystojności i dobrego tonu w pożyciu towarzyskiem, zebrał i według najlepszych wzorów francuzkich ułożył P.E. Leśniewski, Warszawa 1843.

Zabrocki L., Z teorii socjolingwistyki, „Biuletyn Polskiego Towarzystwa Językoznawczego” 1972, t. XXX.

Zaręba A., Formy zwracania się do osób drugich w języku polskim i francuskim, „Język Polski” 1981, R. LXI.

Zdaniukiewicz A., Spór o istotę kultury w pierwszej połowie XIX w., „Język Polski” 1979, R. LIX.

Zgółkowa H., ,Dobranoc” jako formuła grzecznościowa i nazwa własna, „Studia Polonistyczne” 1979, t. VI.

Zgółkowie H. i T., Językowy savoir-vivre. Praktyczny poradnik posługiwania się polszczyzna w sytuacjach oficjalnych i towarzyskich, Poznań 1993.

Żydek-Bednarczuk U., Struktura tekstu rozmowy potocznej, Katowice 1994. 